"The diversity of agriculture and human culture are bound together. In the end it is up to all of us as governments and communities and individuals to prize diversity."

Cary Fowler and Pat Mooney 


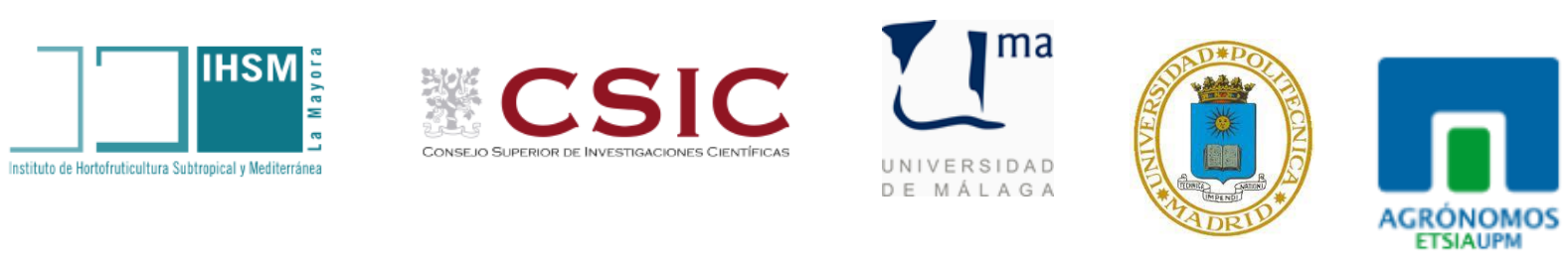

ORIGEN, DISPERSIÓN Y DIVERSIDAD DEL CHIRIMOYO (ANNONA CHERIMOLA MILL.)

EN EL CONTINENTE AMERICANO

Memoria de tesis doctoral presentada por

\section{Nerea Larrañaga González}

para optar al grado de Doctora por la Universidad Politécnica de Madrid, programa de Doctorado en Biotecnología y Recursos Genéticos en Plantas y Microorganismos Asociados.

Director:

Dr. José Ignacio Hormaza Urroz, Profesor de Investigación.

Septiembre de 2016 
Universidad de Málaga, Consejo Superior de Investigaciones Científicas

Instituto de Hortofruticultura Subtropical y Mediterránea La Mayora (IHSM-UMA-CSIC)

29750 Algarrobo -Costa (Málaga)

José Ignacio Hormaza Urroz, Profesor de Investigación del Consejo Superior de Investigaciones Científicas en el Instituto de Hortofruticultura Subtropical y Mediterránea La Mayora y director del Departamento de Fruticultura,

\section{CERTIFICA}

que Nerea Larrañaga González, Licenciada en Biología y Máster en Recursos Fitogenéticos ha realizado en el Departamento de Fruticultura del Instituto de Hortofruticultura Subtropical y Mediterránea La Mayora (IHSM-UMA-CSIC), bajo su dirección, el trabajo de investigación que con el título "Origen, dispersión y diversidad del chirimoyo (Annona cherimola Mill.) en el continente americano" presenta para optar al grado de Doctora por la Universidad Politécnica de Madrid.

Septiembre de 2016

Fdo. Dr. José Ignacio Hormaza Urroz 


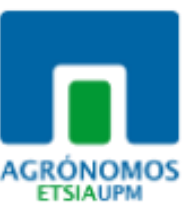

Universidad Politécnica de Madrid

Escuela Técnica Superior de Ingeniería Agronómica, Alimentaria y de Biosistemas

Departamento de Biotecnología - Biología Vegetal

28040 Madrid

Juan Bautista Martínez Laborde, profesor titular del Departamento de Biotecnología-Biología Vegetal de la Escuela Técnica Superior de Ingeniería Agronómica, Alimentaria y de Biosistemas de la Universidad Politécnica de Madrid

\section{AUTORIZA}

la presentación de la Tesis Doctoral titulada "Origen, dispersión y diversidad del chirimoyo (Annona cherimola Mill.) en el continente americano" de la doctoranda Nerea Larrañaga González realizada en el Departamento de Fruticultura del Instituto de Hortofruticultura Subtropical y Mediterránea La Mayora (IHSM-UMA-CSIC), para optar al grado de Doctora por la Universidad Politécnica de Madrid.

Septiembre de 2016

Fdo. Dr. Juan Bautista Martínez Laborde 
Este trabajo se ha llevado a cabo en el Departamento de Fruticultura del Instituto de Hortofruticultura Subtropical y Mediterránea La Mayora, instituto mixto del Consejo Superior de Investigaciones Científicas y la Universidad de Málaga gracias a una ayuda predoctoral de Formación de Personal Investigador (FPI) (BES-2011-047451) del Ministerio de Economía y Competitividad de España, asociada al proyecto AGL2010-1514. 
Tribunal nombrado por el Magfco. y Excmo. Sr. Rector de la Universidad Politécnica de Madrid, el día

Presidente:

Vocal:

Vocal:

Vocal:

Secretario:

Suplente:

Suplente:

Realizado el acto de defensa y lectura de la tesis el día de de 2016 en la E.T.S. de Ingeniería Agronómica, Alimentaria y de Biosistemas de la Universidad Politécnica de Madrid.

CALIFICACIÓN...........

PRESIDENTE

SECRETARIO

VOCALES 
Parte de los resultados de esta Tesis Doctoral se incluyen en los siguientes artículos publicados en revistas científicas recogidas en el SCI y capítulo de libro:

Larranaga N, Hormaza Jl (2015) DNA barcoding of perennial fruit tree species of agronomic interest in the genus Annona (Annonaceae). Frontiers in Plant Science, 6: 589 (Anexo 1).

Larranaga N, Jl Hormaza (2016) Advances in genetic diversity analysis in fruit tree crops. Lüttge U, Cánovas FM, Matyssek R. Progress in Botany 77. Springer International Publishing, Switzerland, 245-264 (Anexo 2).

Larranaga N, Albertazzi F, Fontecha G, Palmieri M, Rainer H, van Zonneveld M, Hormaza, Jl (2016) A Mesoamerican origin of cherimoya (Annona cherimola Mill.), implications for the conservation of plant genetic resources. Molecular Ecology (en revisión).

Y presentados en los congresos

Larrañaga N, Albertazzi F, Fontecha GA, Palmieri M, van Zonneveld M, Hormaza Jl (2013) Cherimoya (Annona cherimola Mill.) genetic diversity and structure across America: possible Central American origin. V International congress on Annonaceae. Botucatu, Brasil, 19-23 de agosto.

Larrañaga N, van Zonneveld M, Albertazzi F, Fontecha GA, Palmieri M, Hormaza Jl (2014) New insights on the center of origin of cherimoya (Annona cherimola Mill., Annonaceae) combining molecular tools and Geographic Information Systems. XXII Plant \& Animal Genome conference. San Diego, EEUU, 11-15 de enero. 


\section{AGRADECIMIENTOS}

Son muchas las personas que de alguna manera han contribuido a la concreción de este trabajo de investigación y a las que quiero dar las gracias.

En primer lugar a agradezco a Iñaki Hormaza, director de esta tesis, por haberme dado la oportunidad, la confianza y gran parte de su tiempo; por lo mucho que he aprendido tanto en lo científico como en lo personal. A todo el grupo del laboratorio de Fruticultura que desde el primer día me hicieron sentir parte de él; gracias a Yolanda, Librada, Carolina, Jorge L., Alicia, The, Celeste, Inma, Marta y Rosa. Y por supuesto a Vero, compañera y amiga.

Gracias a Juan B. Martínez, tutor académico de esta tesis, siempre dispuesto a recibirme y echarme un cable con los trámites administrativos.

Gracias a Federico Albertazzi, Gustavo Fontecha, Maarten van Zonneveld y Lars Chatrou por acogerme en sus respectivas instituciones (y ciudades) durante las estancias internacionales en San José, Tegucigalpa, Cali y Wageningen. Han sido experiencias enriquecedoras en todos los sentidos. No me olvido de Mariela, Clara, Elisa, Marlon, María, Óscar, Melisa, Dani, Jenifer y el resto del equipo que me recibió durante esos meses. También agradezco las colaboraciones con Margarita Palmeri (Guatemala) y Jorge Andrés (México).

Agradezco al resto de compañerxs del Centro y del cuartito, con quienes hemos compartido mucho más que un lugar de trabajo: María, Anabel, Olaya, Yazmín, Jorge, Kike, Cañi, Mariola, Willy, Reme, Rida, Sara, Jota, Paco, Elisa, Eduardo, Pedro, Martin, Anelise, Davinia, Paola, Rima, Isa, Elvira, Antonio, Luis, Irene y tantos otrxs. Y en general, a todo el personal de la Mayora, con especial mención al departamento de Informática por su ayuda en lo referente a programas y otros dramas tecnológicos, a los compañerxs de campo y de administración. Gracias también a Antonio Matas por darme acceso al servidor de $\mathrm{R}$ de la UMA, a Silvia Martín de la UPM por la orientación con toda la documentación y a Ricardo Ontiveros por su asesoría con R.

Gracias a mis amigxs de siempre, porque nunca han dejado de acompañarme y de tratar de entender por qué el estudio de la diversidad genética del chirimoyo es tan importante. A mis padres: Sabin (quien ha hecho la portada) y Ángeles (quien ha dibujado la chirimoya), y a mi hermana Leire, que me apoyan incondicionalmente. A mi pareja, David, quien conoce cada punto y coma de este trabajo y está a mi lado con cada decisión. A Trufa, mi perrita, que se ha pasado las tardes de los últimos meses sin apenas salir y tumbada junto a mi mesa.

Finalmente, quiero dar las gracias a las instituciones responsables de esta Tesis: al CSIC, a la Universidad Politécnica de Madrid y a la beca del Ministerio de Economía y Competitividad que me fue otorgada. También a todas las entidades públicas y grupos de investigación donde he recibido la formación académica y científica previa. 


\section{RESUMEN}

En este trabajo se ha profundizado en las razones que pueden explicar la distribución actual de la diversidad genética del chirimoyo (Annona cherimola Mill.), una especie frutal adaptada a climas subtropicales, con claras implicaciones para su uso y conservación. Gracias a un estudio de código de barras, se pudo comprobar el poder de discriminación del gen cloroplastídico maturasa $\mathrm{K}$ (matK) entre las especies con mayor importancia agronómica del género. Además, sobre los polimorfismos de nucleótido único (SNPs) interespecíficos, se diseñaron marcadores que permitieron la identificación mediante presencia o ausencia de bandas en geles de electroforesis de dichas especies tras PCR. El marcador específico del chirimoyo se utilizó para amplificar un gran número de muestras y estudiar la variabilidad intraespecífica respecto a los SNPs elegidos. Se verificó la existencia de dos haplotipos con diferenciación espacial: (1) con presencia únicamente en Centroamérica y (2) en Centroamérica y resto de orígenes de las accesiones del banco de germoplasma del IHSMUMA-CSIC. A través de un estudio filogenético, basado en cinco loci cloroplastídicos, se determinó que esta especie conforma un grupo monofilético con otras especies cercanas, las cuales tienen una distribución exclusivamente centroamericana y caribeña. De entre las accesiones de chirimoyo incluidas en este ensayo, la mexicana y hondureñas (que presentan el haplotipo único de Centroamérica para matk) se posicionaron en la base del clado que reúne a todas las accesiones de la especie y no se distinguieron de las muestras de Annona pruinosa. La aproximación espacial para analizar diferentes índices de diversidad genética a partir de una base de datos final de 1843 accesiones de chirimoyo y nueve marcadores microsatélite, mostró como los valores en la zona centroamericana (preferentemente Honduras y Guatemala) fueron más altos en comparación con el norte de Perú, donde se observaron los valores más altos de América del Sur. Además, diferentes análisis para estudiar la estructura genética de estas poblaciones muestran que las accesiones tienden a agruparse según su origen geográfico. A medida que se asumieron más poblaciones, fueron las accesiones de América del Sur las que se fragmentaron en diferentes grupos norte-sur. Por último, se estudió el flujo genético entre las diferentes poblaciones y la correlación con las distancias geográficas de mínimo coste, teniendo en cuenta diferentes escenarios que, a su vez, recogían distintas variables que pudieran estar implicadas en la distribución actual de su diversidad, posibles rutas de dispersión o variables ambientales.

Todo lo anterior nos hace concluir que lo más probable es que esta especie se originara en la zona centroamericana, concretamente en Honduras y Guatemala (o que las poblaciones allí asentadas actualmente sean las más ancestrales) y desde allí se dispersara hacia otras zonas de Centroamérica, gracias a sus dispersores naturales y sus amplios corredores biológicos. La llegada, hace unos 12.000-20.000 años, y posterior asentamiento 
de los humanos, mediaría la dispersión hacía America del Sur, posiblemente entre México y Norte de Perú/Ecuador, vía marítima. A raíz de los resultados obtenidos, se recomienda poner en marcha proyectos de conservación, ex situ e in situ, para la preservación de la diversidad existente en las zonas rurales muestreadas de Honduras y Guatemala. Esto debe tener en cuenta, además, que gran parte de las áreas de dichos países, donde se cumplen las condiciones climáticas más propicias para la especie, podrían dejar de serlo en las décadas futuras debido al cambio climático, como muestra el análisis de distribución futura de la especie también llevado a cabo. 


\section{SUMARY}

In this work, the reasons that could explain the current genetic diversity distribution of the subtropical fruit tree species Annona cherimola, with clear implications in use and conservation projects, were studied. DNA barcoding studies demonstrated the discrimination power of the chloroplast gene maturase $\mathrm{K}$ (matK), among the most agronomical important species of the genus. In addition, specific markers based on interspecific simple nucleotide polymorphisms (SNPs) were designed and permitted the identification of the different species, by presence/absence of bands in gel electrophoresis after PCR. The cherimoya specific marker was used to amplify a large dataset, and analyze the intraspecific variability with respect to the SNPs used. Two haplotypes were encountered with geographic differentiation: one of them was just present in the samples from Central American countries, while the other was also present in the rest of the accessions of the IHSM-UMA-CSIC germplasm bank. A phylogenetic study with five cloroplastidic loci determined that this species forms a monophyletic group with other genetically close species, which have an exclusively Central American and Caribbean distribution. Among the cherimoya accessions included in this study, the Mexican and the Honduran (that showed the matK Central American haplotype) were in the base of the clade that included all the accessions of the species, and could not be distinguished from the Annona pruinosa samples. The spatial approach used to analyze several genetic diversity indexes of a 1843 cherimoya accession dataset and nine microsatellite markers, showed higher values in Central America (mainly in Honduras and Guatemala) in comparison with Northern Peru, where the highest values among all South American locations were obtained. In addition, different analyses to study the genetic structure of this dataset showed that all the accessions tended to cluster depending on their geographic origin. The more populations were assumed to exist the more fragmented in different groups the accessions of South America were, in a north-south range. Finally, the genetic flow among different populations was studied and its correlation with the geographic least cost distances was tested, based on different scenarios. These transition layers took into account different variables that could be shaping the current genetic diversity distribution, different dispersion routes or climatic variables.

For all the reasons explained above, we concluded that cherimoya very likely originated in Central America, specifically in Honduras and Guatemala (or that these populations are the most ancestral ones), and from there it was dispersed to other Central American regions, by its natural dispersers and large biological corridors. The arrival and posterior settlement of humans, 12,000-20,000 years ago, could have mediated the cherimoya dispersion to South America, between Mexico and North of Peru, in particular by the sea. The results obtained show the necessity of implementing conservation projects in 
most of the rural areas sampled in Honduras and Guatemala. For this, we should also keep in mind that most areas in these countries where the best climatic conditions for cherimoya growth are present, would be probably lost during the next decades due to the global warming, as shown in the future distribution analyses also carried out. 
ÍNDICE 
$\begin{array}{lr}\text { Introducción general } & 16\end{array}$

$\begin{array}{ll}\text { Árboles frutales, recursos genéticos de plantas } & 17\end{array}$

$\begin{array}{lr}\text { Código de barras (DNA Barcoding) } & 19\end{array}$

Marcadores moleculares para cuantificar la diversidad genética $\quad 20$

$\begin{array}{ll}\text { Metodologías de filogenia } & 24\end{array}$

Genética del paisaje y sistemas de información geográfica 25

Familia Annonaceae y género Annona 26

$\begin{array}{ll}\text { Annona cherimola } & 28\end{array}$

Descripción botánica 28

$\begin{array}{ll}\text { Origen geográfico } & 29\end{array}$

Usos e importancia económica 30

Banco de chirimoyo del IHSM-UMA-CSIC 31

Objetivos 33

Capítulo 1: DNA barcoding of perennial fruit tree species of agronomic interest in the genus Annona (Annonaceae) 35

$\begin{array}{ll}\text { Abstract } & 36\end{array}$

$\begin{array}{ll}\text { Introduction } & 36\end{array}$

$\begin{array}{ll}\text { Materials and methods } & 39\end{array}$

$\begin{array}{ll}\text { Results } & 44\end{array}$

$\begin{array}{ll}\text { Discussion } & 49\end{array}$

Capítulo 2: Application of cherimoya specific markers in a germplasm collection with geographical implications on its diversity and dispersion 51

$\begin{array}{ll}\text { Abstract } & 52\end{array}$

$\begin{array}{ll}\text { Introduction } & 52\end{array}$

Materials and methods $\quad 53$

$\begin{array}{ll}\text { Results } & 56\end{array}$

$\begin{array}{ll}\text { Discussion } & 59\end{array}$

Capítulo 3: Phylogenetic study of the Atta section and closely related species in the genus Annona, Annonaceae 62

$\begin{array}{ll}\text { Abstract } & 63\end{array}$ 
Introduction

Materials and methods 65

Results 68

Discussion 70

Capítulo 4: A Mesoamerican origin of cherimoya (Annona cherimola Mill.), implications for the conservation of plant genetic resources

Abstract 76

Introduction 76

Materials and methods 78

Results 82

Discussion 88

Capítulo 5: Crop exchange before 1492: cherimoya reveals precolumbian dispersal routes in the Americas

Abstract 92

Introduction 92

Materials and methods 95

Results 100

Discussion

Discusión general

Origen y dispersión de Annona cherimola

Conservación de los recursos de Annona cherimola

Taxonomía y relaciones filogenéticas de Annona cherimola y especies cercanas

Conclusiones

Bibliografía

\section{ANEXO 1}

\section{ANEXO 2}




$$
Q_{2}
$$




\section{Árboles frutales, recursos genéticos de plantas}

La aparición de la agricultura y la ganadería hace unos 7.000-10.000 años en diferentes lugares del planeta simultáneamente, significó un punto de inflexión tanto para la especie humana como para el resto de organismos y ecosistemas. Este hecho hizo posible el cambio de una vida nómada basada en la caza y recolecta al sedentarismo basado en la domesticación de plantas (Esquinas-Alcazar 2005). De hecho, el primer capítulo del Origen de las Especies de Charles Darwin (Variation under domestication) está dedicado a la variación a través de la domesticación y en él se defiende el paralelismo de los procesos de domesticación con los evolutivos (Darwin 1959). El proceso de domesticación de plantas puede entonces definirse como un proceso mediante el cual la selección humana de fenotipos de poblaciones elegidas, manejadas o cultivadas resulta en cambios en los genotipos de la población que las hacen más útiles a los humanos y mejor adaptadas a la intervención humana en el paisaje (Clement 1999). De esta manera, se han ido generando un gran número de cultivares a partir de especies silvestres, proceso que ha continuado en las últimas décadas en programas de mejora formales para producir cultivares modernos. Estos recursos permiten la subsistencia de la especie humana y, por tanto, es fundamental el mantenimiento, el uso sostenible e incluso la creación de diversidad genética de los mismos para las presentes y futuras generaciones. Cuanto más diverso es un acervo genético, más capacidad potencial de resiliencia tiene ante cambios ambientales (Lin 2011; Neaves et al. 2013).

Este enfoque cobra todavía más importancia en el actual escenario de cambio climático y otras amenazas ambientales/sociales causadas por el ser humano que han dado lugar a una dramática pérdida de recursos genéticos (y otros), conocida como erosión genética. Según la FAO (nd) dicha pérdida puede haber llegado al $75 \%$ en el último siglo, reduciéndose dramáticamente la información disponible para una selección natural o artificial por productores o mejoradores. Esto, a su vez, reduce la capacidad de adaptación a un ambiente cambiante o, incluso, condiciones oscilantes de mercado y, por tanto, amenaza la seguridad alimentaria. Además, cabe señalar que a nivel global, el uso y la conservación de los recursos filogenéticos se ha centrado en unas pocas especies. Así, de las aproximadamente 7.000 especies de plantas que han sido utilizadas por los seres humanos a lo largo de su historia, actualmente sólo unas 30 suponen más del $90 \%$ del aporte a la dieta humana y únicamente tres cereales (trigo, arroz y maíz) suman dos tercios (UNEP 2007; Cassman 1999). Sin embargo, hay cientos de especies abandonadas o infrautilizadas (neglected and underutilized species) (NUS) que son importantes, al menos en mercados locales, y cuyo cultivo podría ser extendido en un futuro. 
Ante esta perspectiva, el establecimiento de proyectos, políticas e investigaciones para la conservación y el uso sustentable de la diversidad genética de los recursos fitogenéticos de plantas y organismos asociados y necesarios en la producción agrícola (polinizadores, simbiontes, parásitos, depredadores, competidores, etc) va en aumento y muchos países a través de acuerdos nacionales o internacionales están empezando a enfocarse en este problema; ejemplos incluyen el Convenio sobre la diversidad biológica de 1992 (http://www.cbd.int/history/) o el Tratado de los recursos genéticos de plantas para la alimentación y cultura en 2001 (http://www. planttreaty.org/).

De las 30 especies de plantas cultivadas más importantes desde el punto de vista productivo, en 2012, sólo cinco son frutales arbóreos o semi-arbóreos: plataneras, cítricos, vides, manzanos y mangos (Faostat 2014) aunque los cultivos perennes ocupan la octava parte de toda la superficie cultivada mundial (McClure et al. 2014). Algunas de las características de los árboles frutales, como su naturaleza perenne, ciclos de muchas generaciones y largos periodos juveniles, dificultan los programas de mejora y los esfuerzos de conservación. Generalmente son especies de propagación vegetativa favoreciendo el cultivo de unos pocos clones seleccionados como cultivares. Como resultado, es habitual que la diversidad genética encontrada en la mayoría de estos cultivares comerciales sea baja aunque con altas tasas de heterogeneidad (McClure et al. 2014). Mientras la mayoría de los cultivos anuales han sido domesticados durante largos periodos de tiempo, solo unas pocas especies de árboles frutales podrían ser consideradas como realmente domesticadas y la mayoría están separadas por pocas generaciones de sus parientes silvestres, los cuales son reservorios de genes con posible interés para condiciones actuales o futuras.

La conservación de especies, cultivares o genotipos de interés de árboles frutales, al igual que en otras especies de interés agronómico, puede realizarse in situ o ex situ. La primera puede ser llevada a cabo a través de la protección de áreas naturales y/o a través del resguardo de campos de cultivo tradicionales (on farm) (Hammer 2003) lo que también incluye la conservación de las metodologías tradicionales así como la interacción con ecosistemas y, por tanto, la coevolución entre todos los elementos que generan nueva diversidad. Los programas de conservación ex situ preservan genotipos aislados en colecciones de campo, bancos de semillas, de tejidos, etc. Algunas de las estrategias seguidas para la eficiencia en la conservación ex situ, principalmente cuando las semillas son recalcitrantes y no pueden ser conservadas en bancos o cuando, en el caso de árboles, el mantenimiento de colecciones muy numerosas es económicamente poco viable, es el establecimiento de colecciones núcleo (van Hintum et al. 2000; Escribano et al. 2008a).

Una correcta identificación, el estudio de las relaciones filogenéticas entre las especies de interés y sus parientes más cercanos, el establecimiento de los puntos de 
máxima diversidad genética o el estudio de la historia del cultivo para conocer las razones de su distribución actual son medidas que aportan conocimiento y apoyan la optimización en el manejo de los recursos genéticos.

\section{Código de barras (DNA Barcoding)}

La taxonomía, ciencia de la clasificación, se aplica dentro de la biología para la ordenación jerarquizada y sistemática, con sus nombres, de los grupos de animales y de vegetales, y resto de seres vivos. Para la unidad básica de jerarquización, la especie, se han propuesto numerosos conceptos (De Queiroz 2007). Entre ellos, se incluye el concepto biológico de especie como grupos de poblaciones naturales que se cruzan real o potencialmente entre sí y que han quedado aislados reproductivamente de otros grupos (Mayr 1942); el concepto fenético de especie como grupo de organismos que son fenotípicamente similares entre sí y diferentes a otros grupos de organismos (Sokal \& Crovello 1970); o variantes del concepto filogenético de especie en las que una especie sería un grupo de organismos que conforman una población o grupo de poblaciones definido por uno o más caracteres apomorfos (Rosen 1979). Ninguno de los conceptos se ha validado frente al resto, pero el concepto biológico de especie es el más utilizado. Sin embargo, en el caso de plantas donde las hibridaciones son frecuentes, este concepto ha de tomarse con cautela al igual que en especies con reproducción asexual. A pesar de su complejidad, la identificación de especies, subespecies o cultivares en el caso de las plantas cultivadas es de suma importancia para hacer una buena planificación para su uso y conservación.

El uso de caracteres botánicos ha sido tradicionalmente la base para la identificación y caracterización de especies nuevas. Actualmente los marcadores moleculares (que se describen con más detenimiento en el siguiente apartado) o las técnicas de código de barras, DNA barcoding, se han convertido en una potente herramienta para complementar el conocimiento taxonómico así como para una rápida identificación para los no expertos en caracterización fenotípica.

DNA barcoding fue definido por Hebert et al. (2003) como una forma de identificar especies que se basa en la búsqueda y adquisición de una manera global de una corta secuencia genética que, mediante comparación con otras, permitiría no solo la discriminación entre especies sino también el descubrimiento de otras nuevas. En 2004 se fundó el consorcio internacional del código de barras de la vida (Consortium for the Barcode of Life) (CBOL) para el desarrollo de un método global. Seis años después se activó el proyecto internacional del código de barras de la vida (iBOL) para el mantenimiento de la biblioteca de referencia BOLD (Barcode of Life Data Systems) (Bhargava \& Sharma 2013). En ella hay disponible una metodología directa que permite hacer una comparación para ver que 
secuencias hasta ese momento almacenadas presentan los valores de distancia más cercanos con la secuencia a analizar. Además, monitorea el número de secuencias y la cobertura de especies. El 31 de marzo de 2016 había 4795777 secuencias de código de barras indexadas en esta base de datos (http://www.boldsystems.org/).

El gen mitocondrial de la citocromo oxidasa (CO1) es la secuencia establecida por consenso para el código de barras de animales (Hebert et al. 2003). Sin embargo, en el caso de plantas los genes mitocondriales no son buenos candidatos por su baja tasa de cambio comparada con la que presentan en animales y, por tanto, no discriminan correctamente en el nivel de especies (Kress et al. 2005; Kress \& Erickson 2007). En 2009 el Grupo de trabajo CBOL recomendó usar la combinación de dos genes mitocondriales como código de barras: maturasa K (matK) y ribulosa bifosfato carboxilasa ( $r b c \mathrm{~L}$ ) (CBOL Plant Working Group 2009). Sin embargo, la resolución de especies mediante estos dos marcadores es frecuentemente incompleta, especialmente en taxones relacionados (Zhang et al. 2012) y se han propuesto porciones adicionales del genoma como la zona intergénica transcrita del operón ribosomal nuclear (internal transcribed spacer) (ITS e ITS2) o el espaciador cloroplastídico intergénico trnH-psbA (China Plant BOL group et al. 2011; Kress et al. 2005; Pang et al. 2012; Chen et al. 2010; Hollingsworth 2011). Los métodos más utilizados en el desarrollo de un estudio de código de barras son los basados en distancias, aunque también se sigue la aproximación basada en diferencias de caracteres entre las secuencias del alineamiento (DeSalle et al. 2005; Taylor \& Harris 2012). Sea cual sea el caso, se necesitan bases de datos lo suficientemente completas con las que comparar la secuencia enigma. En el capítulo 1 se discute dicha aplicación a especies del género Annona (Larranaga \& Hormaza 2015) y otros ejemplos en árboles frutales incluyen: Prunus sect. persica (Quan \& Zhou 2011) y Phoenix dactylifera (Enan \& Ahamed 2014).

\section{Marcadores moleculares para la medida de la diversidad genética}

La diversidad genética puede ser definida como la cantidad de variabilidad genética entre individuos de una variedad, población o especie (Brown 1983). La nueva variación genética, introducida a través de mutaciones, se reorganiza en poblaciones con una reproducción sexual, a través de tres mecanismos; el sobrecruzamiento, la distribución independiente de los cromosomas durante la meiosis (Alberts et al. 2002) y la fertilización aleatoria de gametos. La distribución y estructura de la diversidad genética dentro y entre las poblaciones depende, a su vez, del flujo genético entre ellas, la deriva genética y la selección natural (Ramanatha Rao \& Hodgkin 2002).

Tradicionalmente, los estudios de diversidad e identificación genotípica en especies de plantas cultivadas, incluyendo árboles frutales, han sido llevados a cabo mediante el uso 
de marcadores morfológicos y caracterización fenotípica. Sin embargo, este proceso es lento y costoso lo que limita el número de genotipos a analizar así como la precisión de las observaciones. Algunas de ellas, como las relativas a las características fenológicas necesitan ser analizadas en un estadio del desarrollo avanzado y algunas características morfológicas o agronómicas pueden estar afectadas por una acción genética pleiotrópica (Le Corre \& Kremer 2003). Aunque estas observaciones son útiles para relacionar fenotipo con genotipo, la caracterización genotípica y la diversidad genética en plantas requiere de estrategias complementarias como las técnicas moleculares (Wünsch \& Hormaza 2002). Durante las últimas décadas se han producido rápidos e importantes avances en los métodos usados en el estudio de los ácidos nucleicos dando lugar al desarrollo de diferentes tipos de marcadores que permiten una estimación fiable de la diversidad genética a nivel de individuo, población o grupo de poblaciones. Aunque el incremento de la disponibilidad de las nuevas técnicas de secuenciación está dando lugar a un cambio, generalmente solo una pequeña parte del genoma es explorado en la mayoría de estudios de diversidad genética y, por ello, la selección de una cantidad correcta de individuos y loci es importante para hacer una extrapolación de los estimadores a las poblaciones naturales o las colecciones de germoplasma (de Vicente et al. 2004; Mondini et al. 2009; Porth \& El-Kassaby 2014). Aunque los marcadores que se describen a continuación a menudo amplifican material nuclear, también son usados con ADN mitocondrial o cloroplastídico para estimar diversidad. Sin embargo, estos genomas son más útiles a nivel inter-específico por su bajo nivel de polimorfismo y son, por ello, de uso común en análisis de código de barras o filogenia.

Los marcadores moleculares pueden ser bioquímicos o basados en secuencias de ADN. Los bioquímicos están basados en la separación de proteínas (alocimas e isoencimas) en un patrón específico de bandas por electroforesis. Son codominantes y su principal desventaja es que están limitados por el bajo número de encimas disponibles y por tanto la resolución de la diversidad es limitada (Mondini et al. 2009). Han sido usados desde 1970 para analizar la diversidad genética de plantas (Brown 1978) y, por tanto, también de árboles frutales como muestran algunos trabajos recientes en manzano (Wagner et al. 2014), avellano (Leinemann et al. 2013) o madroño (Takrouni et al. 2012). Los marcadores basados en ADN, generalmente llamados marcadores moleculares y en constante desarrollo desde los 80 , pueden estar asociados o no con una determinada característica funcional, y se dividen en dominantes (como RAPDs o AFLPs) o codominantes (RFLPs, microsatellite o SNPs) dependiendo de si los genotipos pueden ser diferenciados entre homocigotos y heterocigotos. Los fragmentos de restricción de longitud polimórfica (Restriction Fragment Length Polymorphism) (RFLPs), han sido ampliamente usados desde que Jeffreys (1979) descubriera los polimorfismos de ADN después de tratar a esta macromolécula con encimas de restricción. Sin embargo, dada la disponibilidad de nuevas técnicas moleculares, su 
aplicación en los estudios de diversidad genética está en desuso aunque hay algunos ejemplos recientes en árboles frutales (Garcia-Ruiz et al. 2013). Desde el diseño de la reacción en cadena de la polimerasa (Polymerase Chain Reaction) (PCR) en los 1980 (Mullis et al. 1986), se han desarrollado diferentes tipos de marcadores basados en ella. Entre los que rutinariamente se usan en trabajos de ecología, evolución, taxonomía, filogenia, y diversidad genética está la amplificación aleatoria de ADN polimórfico (Random Amplification of Polymorphic DNA) (RAPDs) mediante la cual fragmentos de ADN son amplificados usando cebadores decámeros de secuencia aleatoria y, por tanto, el polimorfismo depende de la presencia o ausencia de un producto de amplificación. Empezaron a ser usados en diferentes organismos a final de los años 80 (Williams et al. 1990) y han sido usados ampliamente en árboles frutales, algunos ejemplos recientes son: granado (Mansour et al. 2015), olivo (Brake et al. 2014), albaricoquero (Yilmaz et al. 2012) o mango (Samal et al. 2012). Los polimorfismos en la longitud de fragmentos amplificados (Amplified Fragment Length Polymorfisms) (AFLPs) (Vos et al. 1995) son otra clase de marcadores que combinan RFLPs y PCR. Algunos ejemplos recientes en árboles frutales serían los de palmera datilera (Sabir et al. 2014), Prunus mira (Li et al. 2014a) o kiwi (Li et al. 2014b). Los polimorfismos de nucleótido único o simple (Simple Nucleotide Polymorphism) (SNPs), que son variaciones en nucleótidos simples, que no cambian la longitud de la secuencia de ADN y ocurren a lo largo de todo el genoma, son cada vez más utilizados (FAO 2007; de Vicente et al. 2004) especialmente desde 2004, fecha en la cual empezaron a ver la luz los métodos de secuenciación de próxima generación (Next Generation Sequencing) (NGS) (Glenn 2011). Estas tecnologías están revolucionando muchas áreas de la biología ya que permiten realizar estudios de genomas enteros (whole-genome sequencing), de porciones funcionales del genoma (exome sequencing), análisis del transcriptoma (RNA-seq) y lugares del ADN de unión de proteínas (ChIP-seq). La principal característica de estas técnicas es la posibilidad de realizar secuenciaciones masivas. Probablemente el factor más importante que hace posible la extensión de estas técnicas es que sus precios cada vez son más accesibles (Sboner et al. 2011).

\section{SSR o microsatélites}

Los marcadores microsatélite (Simple Sequence Repeat o Short Tandem Repeat) (SSR o STR) están basados en la presencia de secuencias cortas de DNA (de 2 a 6 nucleótidos) repetidas y flanqueadas por regiones específicas que permiten su amplificación por PCR. Estos marcadores son codominantes, están ampliamente extendidos por todo el genoma incluyendo los genomas de los organelos (mitocondria y cloroplasto), tienen naturaleza multialélica, son relativamente abundantes, altamente polimórficos, reproducibles y 
presentan disposición para la automatización y buen rendimiento en genotipado. Los análisis genéticos basados en microsatélites se fundamentan en las diferencias de tamaño de los alelos que se asocian a la variación del número de motivos repetidos en tándem. La unión incorrecta de las cadenas de ADN durante la replicación (Replication Slippage), debido a una estructura terciaria anormal de la región repetitiva del ADN, se considera como el mecanismo principal de generación de nuevos alelos microsatélite aunque también pueden ser originados por sobrecruzamientos incorrectos durante la meiosis, y retrotransposición (Kalia et al. 2011, Ellegren 2004, Parida et al. 2009). Se han propuesto varios modelos de mutación para las secuencias microsatélites como el modelo de alelos infinitos (Infinite Allele Model) (IAM), el de mutación paso a paso (Stepwise Mutation Model) (SMM), o el de formación de un número $\mathrm{k}$ de alelos (K-Allele Model) (KAM). En cada modelo, excepto en el IAM, cada mutación da lugar a la creación de un alelo nuevo, pudiéndose generar de manera independiente alelos idénticos en tamaño. Además, la secuenciación de alelos de igual tamaño ha permitido demostrar variaciones en las secuencias nucleotídicas originándose así varios tipos de homoplasia. A pesar de que ésta puede dificultar el uso de estos marcadores en estudios filogenéticos, parece no ser un inconveniente significativo en los análisis de genética de poblaciones ya que queda compensada con la gran variabilidad que presentan estos marcadores (Ellegren 2000; Estoup et al. 2002). Algunos ejemplos recientes de su uso en estudio de diversidad en frutales son: vid (Basheer-Salimia et al. 2014), albaricoquero (Raji et al. 2014; Martin et al. 2011), castaño (Beghe et al. 2013), litchi (Madhou et al. 2013) o peral (Sehic et al. 2012).

Otros marcadores basados en PCR son los marcadores de intersecuencia simple (Inter Simple Sequence Repeat) (ISSR), aplicados, por ejemplo, en higuera (Amel et al. 2004; 2005; Ikegami et al. 2009) o clementina (Breto et al. 2001), los de secuencia polimórfica amplificada y cortada (Cleaved Amplified Polymorphism) (CAPs) usados, por ejemplo, en Citrus spp. (Amar et al. 2011), la región amplificada caracterizada y secuenciada (Sequenced Characterized Amplified Region) (SCAR) usados, por ejemplo, en caqui (Cho et al. 2013), lugar etiquetado para la secuencia (Sequence Tagged Site) (STS) y lugar etiquetado para la expresión (Expressed Sequence Tag) (EST) usados, por ejemplo, en Musa acuminata (Passos et al. 2012) o Actinidia spp. (Crowhurst et al. 2008). Estudios adicionales incluyen otros marcadores moleculares como polimorfismos del codón iniciación (Start Codon Targeted Polymorphism) (SCoT), que usa cebadores únicos diseñados para hibridar con las regiones flanqueantes al codón de iniciación ATG en ambas cadenas el cual se ha usado, por ejemplo, en mango (Gajera et al. 2014; Luo et al. 2011). Otros, como polimorfismo amplificado de secuencias relacionadas (Sequence Related Amplified 
Polymorphism) (SRAP) ha sido usado en albaricoquero (Li et al. 2014c), caqui (Jing et al. 2013a) o almendro (Jing et al. 2013b), así como los polimorfismos para la amplificación de regiones blanco (Target Region Amplification Polymorphism) (TRAP) que se han usado en manzano (Guo et al. 2009). Otro grupo de marcadores está basado en elementos móviles como los polimorfismos en la amplificación de regiones inter-retrotransposon (InterRetrotransposon Amplified Polymorphism) (IRAP), usados en Musa spp. (Nair et al. 2005) o Dyospiros spp. (Du et al. 2009a, 2009b), los polimorfismos de microsatélites en retrotransposones amplificados (Retrotransposon-Microsatellite Amplified Polymorphism) (REMAP), usados en Dyospiros spp. (Du et al. 2009a, 2009b) o Prunus mume (Shen et al. 2011), los polimorfismos basados en retrotransposones insertados (Retrotransposon-Based Insertion Polymorphisms) (RBIP) en Pyrus pirifolia (Kim et al. 2012) o los polimorfismos de amplificación específica de secuencia (Retrotransposon based Sequence-Specific Amplification Polymorphism) (SSAP) en Anacardium occidentale (Syed et al. 2005) o Dyospiros spp. (Du et al. 2009a, 2009b).

\section{Metodologías de filogenia}

La sistemática cladista, surgida a partir de los escritos de Hennig (1950), se define como la parte de la biología que se encarga de clasificar a las especies en función de su historia evolutiva (filogénesis) basándose en el reconocimiento de grupos monofiléticos (clados) y la importancia de los caracteres derivados (sinapomorfías) (Daly et al. 2001). Los resultados de los análisis filogenéticos a partir del análisis de caracteres discretos homólogos (y sus estados) son representados en árboles con ramas proporcionales a la cantidad de cambios o con ramas que sólo muestran la topología sin información adicional (cladogramas) (Baldauf 2003), siendo hipótesis de las relaciones evolutivas. Tradicionalmente se han basado en el análisis de caracteres morfológicos pero con la llegada de la secuenciación de ADN, las secuencias nucleotídicas o aminoacídicas tanto nucleares como plastidiales han supuesto la principal fuente de información. En plantas, se ha extendido el uso del cloroplasto para inferir las relaciones históricas entre las especies por su pequeño y relativamente constante tamaño, estructura y contenido genético entre las angiospermas (Palmer 1985), a pesar de que, en la mayoría de los casos, sólo informa sobre la línea materna. El cloroplasto típico de angiospermas tiene un tamaño que varía entre 135 y $160 \mathrm{~kb}$ y se caracteriza por un largo fragmento invertido de ca. 25kb que divide al resto del genoma en una copia simple larga y otra pequeña (Olmstead \& Palmer 1994). Aunque existen diferentes métodos para la inferencia de las relaciones filogenéticas, éstos se pueden agrupar en dos categorías: métodos de distancia y métodos de caracteres. Los métodos de distancia convierten la información de similitud entre los pares de secuencias en distancias de evolución y, mediante 
un algoritmo, construyen un único árbol siguiendo una serie de pasos definidos (UPGMA; $\mathrm{NJ}$ ). Son métodos bastante rápidos pero la desventaja es que la información evolutiva se pierde cuando la similitud global es observada más que los eventos de mutación individuales. Los métodos de caracteres se basan en un criterio de optimización para dar un valor a cada posible árbol construido a partir de caracteres discretos y no matrices de distancias y, posteriormente, seleccionan a aquellos que maximizan (o minimizan) dicho criterio (Saitou 1996; Swofford et al. 1996, Lewis 2001). Los tres métodos basados en el uso de criterios de optimización más utilizados son: máxima parsimonia, que minimiza la longitud del árbol y ha sido empleada, por ejemplo, en Citrus spp. (Uchoi et al. 2016) o en Malus spp. (Volk et al. 2015), máxima verosimilitud, que maximiza la probabilidad de los datos dada una hipótesis (árbol) y modelo evolutivo y ha sido utilizada en un gran número de estudios de árboles frutales como en la familia Rosaceae (Lo \& Donoghue 2012), y la inferencia bayesiana que maximiza la probabilidad posterior o la probabilidad de una hipótesis dados los datos y que ha sido empleada, por ejemplo, en Prunus spp. (Shi et al. 2013). Los dos últimos permiten introducir diferentes modelos de sustitución de nucleótidos, como, por ejemplo, el modelo general de tiempo reversible (general time reversible model) (GTR) que permite, a diferentes tasas, las posibles 6 transiciones entre los distintos estados de carácter (nucleótidos) (Lewis 2001).

\section{Genética del paisaje y uso de Sistemas de Información Geográfica}

Un genotipo determinado se genera como resultado de distintos procesos como mutación, selección, flujo genético y deriva genética. Por ello, las consideraciones espaciales son claves para entender la evolución (Jarvis et al. 2005), así como el patrón de diversidad genética y estructura de cualquier especie para contribuir a mejorar el conocimiento de las dinámicas temporales y espaciales (Thomas et al. 2012a). Guarino et al. (2002) define los Sistemas de Información Geográfica (Geographic Information Systems) (GIS) como un sistema de gestión de datos que puede simultáneamente manejar datos espaciales en forma de gráficos, (dónde), y relacionado y lógicamente adjunto, atributos no espaciales, (qué). Estas herramientas resultan muy útiles en el estudio de la distribución de la diversidad y estructura genética pues "el dónde" puede ser la localización de los puntos de presencia de diferentes individuos y "el qué" podrían ser, por ejemplo, nombres de especies o información morfológica o molecular que caracteriza cada muestra. El análisis espacial a través de GIS puede, por tanto, ser destinado a una amplia gama de aplicaciones en la caracterización, conservación y uso de la diversidad de los recursos genéticos de plantas (Escudero et al. 2003; Scheldeman \& van Zonneveld 2012). Algunos trabajos recientes han analizado la diversidad genética de árboles frutales con una aproximación espacial para la obtención de 
índices de diversidad tanto con datos morfológicos como moleculares; Jatropha curcas (Sunil et al. 2009), Annona cherimola (van Zonneveld et al. 2012), Theobroma cacao (Thomas et al. 2012a).

La genética del paisaje (Landscape genetics), un campo de estudio relativamente nuevo, se trata de una aproximación que combina características espaciales de la zona de estudio (ecológicas, geológicas, etc) y genética de poblaciones para proveer información sobre procesos microevolutivos como flujo genético, deriva genética y selección (Manel et al. 2003, Manel \& Holderegger 2013). En este campo naciente se pueden, por tanto, combinar la alta resolución de los marcadores moleculares con datos espaciales y una variedad de métodos estadísticos para evaluar el rol que las variables paisajísticas juegan en el modelado de la diversidad genética y la estructura poblacional (Storfer et al. 2007). La genética de paisaje se ha ocupado de distintos asuntos (Storfer et al. 2010; Cassini 2013): identificación de barreras para la dispersión, cuantificación de la diversidad, inferencia de los efectos por el cambio del paisaje, identificación de migrantes en relación con las condiciones del paisaje, estimación de las dinámicas fuente-sumidero, predicción en la difusión de una enfermedad o una especie invasiva y comparación de patrones genéticos observados entre paisajes actuales y pasados. De acuerdo con Holderegger et al. (2010), tres son las estrategias más usadas para estudiar fenómenos como la migración, dispersión o el flujo genético a través de variaciones genéticas neutras; distancia/resistencia de paisaje (Landscape distance/resistance), técnica de superposición (Overlay technique) y evaluación del flujo genético actual (Assessment of contemporary gene flow). Por otro lado, se empieza también a estudiar la interacción entre el ambiente y la variación genética adaptativa. Hasta 2010, los estudios de genética del paisaje habían estado basados principalmente en vertebrados, $(62 \%)$, invertebrados $(18 \%)$ y plantas $(14.5 \%)$ seguidos por bacterias $(3 \%)$, virus (3\%), líquenes (1\%) y hongos (0.5\%) (Storfer et al. 2010). Recientemente, se han publicado algunos estudios en árboles frutales con Castanea sativa (Martin et al. 2012) o Juglans regia (Pollegioni et al. 2014).

\section{Familia Annonaceae y género Annona}

La familia Annonaceae incluye aproximadamente 108 géneros y 2400 especies de árboles y lianas, tropicales y subtropicales, distribuidas por todo el mundo (Chatrou 1999, Chatrou et al. 2012). Según la clasificación APG III (Stevens 2001), esta familia se sitúa en el orden Magnoliales junto a otras cinco familias (Myristicaceae, Degeneriaceae, Himantandraceae, Magnoliaceae y Eupomatiaceae) representando tres cuartas partes del mismo y el cual, junto a los órdenes Canellales, Laurales y Piperales, forman el complejo Magnoliid (Zanis et al. 2002) dentro de las angiospermas basales (Soltis et al. 2005). Se cree que las anonáceas 
surgieron en el Cretácico Superior hace unos 82-98 millones de años, cuando los taxones podían distribuirse entre Laurasia y el norte de Gondwana (Doyle \& Le Thomas 1997; Richardson et al. 2004; Scharaschkin \& Doyle 2005; Su \& Saunders 2009). Una escisión en una línea de Laurasia dio lugar al género Anaxagorea (presente en los neotrópicos y Asia tropical) y la línea de Gondwana dio lugar al resto de la familia. La familia cuenta con algunos géneros que incluyen a más de 100 especies como Guatteria, Annona, Duguetia, Uvaria y Polyalthia (Chatrou et al. 2004).

Desde la clasificación de Fries (1959) se han llevado a cabo varios trabajos dedicados a la sistemática de esta familia o géneros que engloba basados en caracteres reproductivos (Doyle \& Le Thomas 1994, 2012; Gottsberger 2012; Saunders 2012; Goodrich 2012), morfológicos (Maas \& Westra 1985a; 1985b; Doyle \& Le Thomas 1996; Su \& Saunders 2006; Couvreur et al. 2009) y moleculares utilizando secuencias cloroplastídicas (Chatrou et al. 2012; Richardson et al. 2004; Mols et al. 2004; Pirie et al. 2005; Su et al. 2010; Erkens et al. 2012a; Thomas et al. 2012b; Chaowasku et al. 2014) y secuencias nucleares como marcadores RAPDs, y RFLPs (van Zuilen 1996). Existe una base de datos en línea de la familia (Rainer \& Chatrou 2006), una recopilación reciente de géneros, especies y taxones intraespecíficos (Maas et al. 2011) así como una recopilación bibliográfica (Erkens et al. 2012b).

Un número limitado de especies, pertenecientes a dos géneros, Annona y Asimina, producen frutos comestibles (Figura I.1) ya que, recientemente, las especies pertenecientes al género Rollinia han sido incluidas en el género Annona (Rainer 2007). Asimina, el único género de la familia adaptado a climas templados, incluye 12 especies (Maas et al. 2011) entre las que se encuentra Asimina triloba, especie nativa de zonas templadas del norte de América con interés agronómico y que ha sido objeto de numerosos estudios con isoencimas, RAPDs, AFLPs e ISSRs (Huang et al. 1997, 1998, 2000, 2003; Pomper et al. 2003; Wang et al. 2005). El género Annona engloba a unas 162 especies (Chatrou et al. 2012) y está distribuido principalmente por las zonas tropicales de América con unas pocas especies nativas de África. Varias especies de este género son comestibles con diversa importancia para los mercados, fundamentalmente, locales: Annona cherimola, A. reticulata, A. squamosa, A. muricata, A. macroprophyllata, A. glabra o A. purpurea (Figura I.1). El género Annona fue nombrado por Linnaeus en 1737 (Linnaeus 1737) y podría haber emergido durante el Mioceno (Richardson et al. 2004; Su \& Saunders 2009). Safford (1914) describe el género y lo divide en 5 grupos y 15 secciones y Fries (1959) lo reorganiza en 17 secciones. Diversos estudios se han llevado a cabo con especies del género Annona tanto a nivel morfológico y/o molecular bien en estudios de identificación, diversidad o filogenia (Ronning et al. 1995; Pinto et al. 2005; Rahman et al. 1997; Chatrou et al. 2009). 

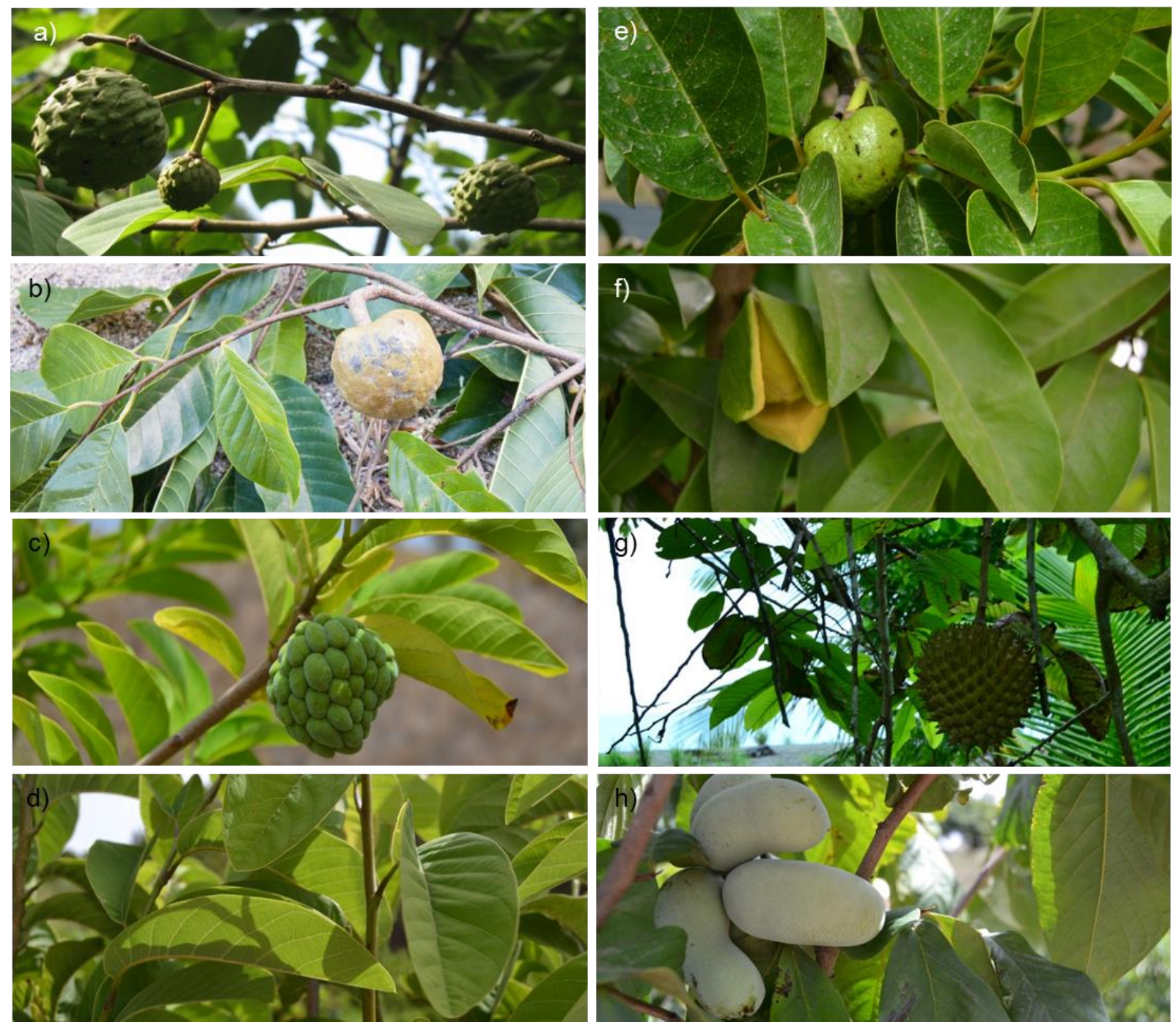

Figura l.1. Fotografías de hojas, frutos o flores; a) $A$. cherimola, b) $A$. reticulata, c) $A$. squamosa, d) $A$. macrophrophyllata, e) A. glabra, f) A. muricata y g) A. purpurea y h) Asimina triloba.

\section{Annona cherimola}

\section{Descripción botánica}

Annona cherimola Mill. (Figure I.2) es un árbol semi-caduco de la sección Atta del género Annona (Fries 1959). Árbol que puede alcanzar los 7-8 metros en su madurez. Las hojas son simples, enteras, de disposición alterna y de forma oval a elíptica: con un tamaño variable, en general de $7-18 \mathrm{~cm}$ de largo y de 4 a $10 \mathrm{~cm}$ de ancho con un peciolo corto (Rosell et al. 1997). Las flores son hermafroditas, colgantes, poco llamativas y aromáticas. Por lo general se originan en la madera de un año o más de edad, pudiendo aparecer solitarias o en grupos de hasta 8 ó 9 por yema. Las piezas florales se disponen de manera helicoidal-piramidal sobre el receptáculo. Cada flor posee tres pétalos grandes (de 2,5 a $4 \mathrm{~cm}$ ) carnosos de color verde y también tres pétalos internos rudimentarios, en forma de escama. Los estambres son 
muy numerosos (150-200). La pirámide de pistilos tiene aproximadamente 150 unidades independientes, con un sólo ovulo, que deben ser polinizados para que los ovarios crezcan y se desarrolle, al fusionarse, el fruto. Las flores presentan dicogamia (separación temporal del estado funcional femenino y masculino) protogínica (maduración de la parte femenina antes que la masculina) lo que dificulta la autofecundación dentro de la misma flor y entre flores del mismo árbol al estar el estado sexual sincronizado (Wester 1910; Lora et al. 2010, 2011a, 2011b). La polinización manual es habitual en España y otros países donde la ausencia del polinizador natural causa un cuajado natural deficiente. El número cromosómico de la mayoría de las anonas es $n=7$ o $n=8$ excepto Annona glabra que es tetraploide $2 n=28$. Annona cherimola ha sido reportada, mayoritariamente, con $2 n=14$ cromosomas (Thakur \& Sigh 1965; Walker 1972) aunque también con $2 n=16$ (Bowden 1948).

\section{Origen geográfico}

La palabra "chirimoya" parece provenir del quechua; chiri, "frío, fría" y muya, "semillas", lo que podría ser debido a que es un árbol adaptado a altitudes elevadas en la región andina. Se distribuye desde México y América Central hasta América del Sur en altitudes superiores a 900-1.000 msnm. Pese a que su centro de origen está en discusión, la teoría más defendida hasta ahora apoya un origen sudamericano de la especie, concretamente en los valles interandinos del sur de Ecuador y norte de Perú, pues allí se han localizado las zonas con mayor variabilidad fenotípica y restos arqueológicos que se consideraron semillas de la especie o representaciones de los frutos (Popenoe 1921; van Damme et al. 2000). Sin embargo, i) el hecho de que esta especie sea la única representante de la sección Atta que se encuentra en Sudamérica mientras el resto de especies estrechamente relacionadas tiene una distribución centroamericana, ii) que se haya reportado mayor disimilitud entre un número limitado de muestras centroamericanas comparado con muestras sudamericanas (Escribano et al. 2007) o iii) posibles confusiones en los restos preincaicos con la especie Annona muricata (Pozorski \& Pozorski 1997) sugieren una hipótesis alternativa en la que la zona mesoamericana podría ser el lugar de origen de la especie. En cualquier caso, el chirimoyo fue domesticado en la antigüedad (Popenoe et al. 1989) y el movimiento de material vegetal entre Mesoamérica y norte de Sudamérica tuvo lugar en tiempos precolombinos (van Damme et al. 2000).

El chirimoyo se introdujo en el sur de España en el siglo XVIII, de donde probablemente se llevó a Italia y Madeira (Portugal), Islas Canarias, Argelia, Egipto y, probablemente a través de Italia, a Libia, Eritrea y Somalia. También en la última década del siglo XVIII se introduce en Hawai, Jamaica y Haití. Desde México se introdujeron semillas en California y a comienzos del siglo XX el departamento de Agricultura de Estados Unidos 
importó semillas de Madeira. Actualmente se encuentra distribuido en casi todos los países con clima subtropical. En España empezó a tener importancia comercial en las décadas 40 y 50 del siglo XX en la provincia de Granada, con una extensión en 1953 de 106 hectáreas (Morton 1987). Actualmente hay aproximadamente 3.000 has de cultivo en España (www.magrama.gob).

\section{Usos e importancia económica}

La chirimoya es una fruta dulce, debido a su alto contenido de azúcares y bajo en ácidos, que principalmente se consume fresca aunque también se utiliza para la elaboración de helados, batidos, sorbetes, yogurt o vino (Scheldeman 2002). En hojas, tallos, corteza y semillas se han detectado metabolitos secundarios como la isoquinolina $y$, al igual que otras especies de las anonáceas, presenta acetogeninas con diversas propiedades farmacológicas como antitumorales o insecticidas (Alaly et al. 1999; Liaw et al. 2011; Cortes et al. 2014). De hecho, tradicionalmente las semillas machacadas han sido utilizadas como insecticidas para combatir los piojos y curar enfermedades de la piel (Scheldeman 2002)

A pesar de que el chirimoyo ya era cultivado por civilizaciones americanas en tiempos precolombinos, actualmente se considera un frutal infrautilizado. Se cultiva en muchas áreas subtropicales distribuidas en todo el mundo. Algunos de los países del continente americano más importantes en la producción de chirimoya son Perú, Ecuador, Chile, Bolivia, México, EEUU o Brasil (Scheldeman 2002). Sin embargo, es España el principal productor mundial, con 3149 has en 2012 (www.magrama.gob). Fino de Jete y Campas son los cultivares más importantes, principalmente el primero que ocupa alrededor del $95 \%$ de la superficie cultivada. Otros países productores de chirimoya son Portugal, Italia e Israel entre los mediterráneos y Australia, Nueva Zelanda, o Sudáfrica a nivel mundial (Scheldeman 2002).

El chirimoyo ha sido objeto de trabajos para el estudio de diversidad, herencia o ligamiento con marcadores morfológicos (Pérez de Oteyza et al. 1999; Andrés et al. 2006), isoencimas (Ellstrand \& Lee 1987; Pascual et al. 1993; Perfectti \& Pascual 1996, 1998a, 1998b, 2004, 2005), RAPDs (Ronning et al. 1995), AFLPs (Rahman et al. 1998) o microsatélites (Escribano et al. 2004, 2007, 2008, 2008b; van Zonneveld et al. 2012). También ha sido objeto de la construcción de diferentes mapas genéticos más o menos saturados basados en marcadores microsatélite en una población de cruce intraespecífico (Escribano 2007; Martin 2013) y en otra de cruce interespecífico con A. squamosa (Martin 2013). La aparición de un mutante natural de $A$. squamosa sin semillas ha permitido identificar un gen (INO) indispensable para la formación de las mismas (Lora et al. 2011b). 


\section{Banco de germoplasma de chirimoyo y otras anonáceas frutales del IHSM-UMA-CSIC}

El Instituto de Hortofruticultura Subtropical y Mediterránea La Mayora se sitúa en la provincia de Málaga, España, en el municipio de Algarrobo, concretamente a $-4.0431^{\circ}$ de longitud y $36.7561^{\circ}$ de latitud (Google Earth). Esta zona presenta un clima mediterráneo con condiciones subtropicales en la que hay cultivos comerciales o experimentales de varias especies subtropicales: aguacate (Persea americana), mango (Mangifera indica), chirimoyo (Annona cherimola), nuez de macadamia (Macadamia sp), carambola (Averrhoa carambola), litchi (Litchi chinensis), lúcumo (Pouteria lucuma) o longan (Dimocarpus longan). En los años 1970 se comenzó a establecer un banco de germoplasma de chirimoyo en el IHSM-UMACSIC con el objetivo de disponer de accesiones que suplieran las deficiencias del cultivar local Fino de Jete y poder llevar a cabo proyectos de mejora genética. En la actualidad el banco cuenta con más de 350 accesiones de chirimoyo y otras anonáceas frutales. El cultivo de chirimoyo en la costa española depende en un 95\% del cultivar Fino de Jete, el cual tiene excelentes calidades organolépticas y está muy adaptado a la zona. Sin embargo, tiene algunas desventajas como es el alto contenido de semillas, la susceptibilidad a la mosca del mediterráneo (Ceratitis capitata), la concentración de la producción en tres meses (octubrediciembre) o una mala poscosecha. Recientemente se ha registrado un nuevo cultivar denominado "Alborán" producto de los proyectos de mejora que se llevan a cabo en el IHSMUMA-CSIC. Éste tiene un índice de semillas inferior a "Fino de Jete" y una calidad excelente en los meses de invierno. De una manera paralela se está buscando un cultivar que no produzca semillas a partir de un cruzamiento inicial entre "Fino de Jete" y un mutante espontáneo de Annona squamosa, Thai seedless (Ts) que produce frutos normales sin semilla. La explicación de este carácter de Ts es la deleción del locus INNER NO OUTER (INO) (Lora et al 2011b) que está implicado en el desarrollo del tegumento exterior del óvulo. Los programas de mejora son mucho más escasos en los países de origen del chirimoyo, donde, a pesar de contar con germoplasma muy diverso, no hay, hasta la fecha un gran interés comercial (Vanhove \& Van Damme 2013). 


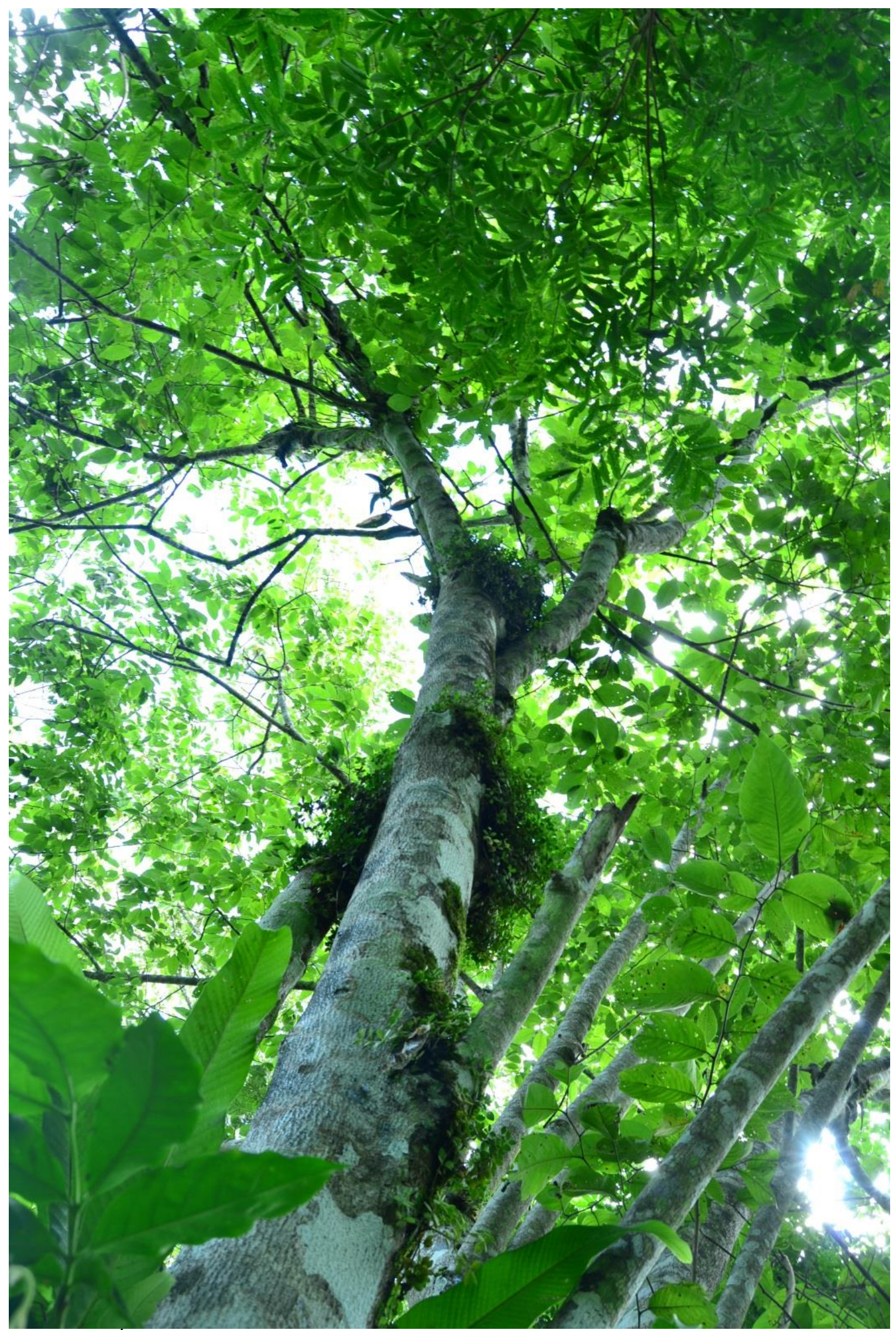

Figura I.2. Árbol de chirimoyo en estado silvestre muestreado en Honduras; longitud -86.7467 , latitud 14.1374 medido en coordenadas geográficas WGS84 y a unos 1270 metros sobre el nivel del mar. 


$$
\infty
$$


El objetivo general del presente trabajo es profundizar en las razones que explican la distribución actual de la diversidad genética de Annona cherimola en las poblaciones silvestres y semi-cultivadas del continente americano, mediante su representación espacial, la inferencia de rutas de dispersión y el estudio de las relaciones filogenéticas con especies estrechamente emparentadas. Además, se desarrolla una metología basada en el código de barras de plantas para su diferenciación con las principales especies de Annona con interés agronómico. Este objetivo general se desglosa en distintos objetivos más específicos:

1. Diseño de marcadores específicos para la especie Annona cherimola y otras especies del género con interés agronómico y estudio de diferenciación utilizando la secuencia matk y rbcL propuestas para el código de barras de plantas (Capítulo 1).

2. Aplicación de los marcadores de chirimoyo diseñados en capítulo 1, en 296 accesiones procedentes del banco de germoplasma del IHSM-UMA-CSIC así como en 250 recolectadas en Guatemala, Honduras y Costa Rica (Capítulo 2).

3. Trabajo filogenético basado en cinco secuencias del ADN del cloroplasto obtenidas de 46 individuos pertenecientes a 17 especies del género Annona; la mayoría de ellas incluidas en la sección Atta del género y secciones cercanas con distribución exclusivamente centroamericana (Capítulo 3).

4. Representación de la distribución de la diversidad genética actual obtenida a partir de la amplificación con marcadores microsatélite de 1762 accesiones y sistemas de información geográfica. Estudio de la estructura de dichas poblaciones y modelo de la distribución espacial de la especie bajo condiciones climáticas futuras (Capítulo 4).

5. Estudio de la dispersión de la especie mediante herramientas de genética del paisaje gracias al desarrollo de diferentes escenarios con posibles variables que pudieran haber condicionado dicho movimiento y la correlación entre las distancias genéticas y geográficas (Capítulo 5). 


$$
\infty
$$




\title{
DNA BARCODING OF PERENNIAL FRUIT TREE SPECIES OF AGRONOMIC INTEREST IN THE GENUS ANNONA (ANNONACEAE)
}

\begin{abstract}
The DNA barcode initiative aims to establish a universal protocol using short genetic sequences to discriminate among animal and plant species. Although many markers have been proposed to become the barcode of plants, the Consortium for the Barcode of Life (CBOL) Plant Working Group recommended using as a core the combination of two portions of plastid coding region, rbcL and matK. In this paper, specific markers based on matK sequences were developed for 7 closely related Annona species of agronomic interest (Annona cherimola, A. reticulata, A. squamosa, A. muricata, A. macroprophyllata, A. glabra, and $A$. purpurea) and the discrimination power of both $r b c \mathrm{~L}$ and matK was tested using also sequences of the genus Annona available in the Barcode of Life Database (BOLD) data systems. The specific sequences developed allowed the discrimination among all those species tested. Moreover, the primers generated were validated in six additional species of the genus ( $A$. liebmanniana, $A$. longiflora, $A$. montana, $A$. senegalensis, $A$. emarginata and $A$. neosalicifolia) and in an interspecific hybrid ( $A$. cherimola $\times$ A. squamosa). The development of a fast, reliable and economic approach for species identification in these underutilized subtropical fruit crops in a very initial state of domestication is of great importance in order to optimize genetic resource management.
\end{abstract}

\section{INTRODUCTION}

Annona L. is the type genus among the approximately 110 included in the Annonaceae (Chatrou et al. 2012), an angiosperm family within the Magnoliales in the Magnoliid clade (APG III 2009). Due to its phylogenetic situation among the early-divergent angiosperms, this family has been subject of a considerable interest from taxonomic and evolutionary points of view. Different molecular markers based on both chloroplast and nuclear sequences have been used to infer phylogenetic relationships among species of the family. Among chloroplast sequences, $r b c \mathrm{~L}$, matK, $n d h \mathrm{~F}$, trnL, $\operatorname{trnT}-\mathrm{L}$, trnL-F, trnS-G, atpB-rbcL, $t r n \mathrm{H}-p s b \mathrm{~A}, \mathrm{ycf} 1, \mathrm{rpl} 32-$ trnL, or ndhF-rpl32 have been used in one or several studies (Richardson et al. 2004; Chatrou et al. 2012; Thomas et al. 2012b; Chaowasku et al. 2014). Among nuclear markers, microsatellite flanking regions were used by Chatrou et al. (2009). Additional molecular markers have been developed in the Annona genus mainly for fingerprinting and genetic diversity studies; isozymes (Ellstrand \& Lee 1987; Pascual et al. 1993; Perfectti \& Pascual 1998a, 2004, 2005), randomly amplified polymorphic DNA (RAPDs) (Ronning et al. 1995), 
amplified fragment length polymorphism (AFLPs) (Rahman et al. 1998) and, more recently, microsatellites (Escribano et al. 2004, 2007b, 2008a, 2008b; Pereira et al. 2008a; van Zonneveld et al. 2012).

Several species of the genus Annona produce edible fruits and have been cultivated and used as a food source by pre-Columbian cultures in Central and South America (Popenoe et al. 1989). Cultivation has continued to the present day and some of them now are incipient but prosperous crops in several developing countries with tropical and subtropical climates: cherimoya (Annona cherimola Mill.), sugar apple (A. squamosa L.), atemoya (Annona $x$ atemoya Mabb., a hybrid between $A$. cherimola and $A$. squamosa), guanabana or soursop ( $A$. muricata L.), custard apple ( $A$. reticulata L.), ilama ( $A$. macroprophyllata Donn. Sm.), pond-apple (A. glabra L.) or soncoya (A. purpurea Moc. \& Sessé ex Dunal). All of them are native of the Neotropics and only $A$. cherimola is adapted to subtropical climates in higher elevations of Central and South America (from 1000 to 3000 m). Among those, cherimoya, sugar apple, guanabana, and atemoya show some commercial importance in various tropical and subtropical regions whereas the other species are generally used only locally with very limited or nonexistent production at a commercial scale. Production data are difficult to find for those species with perhaps the exception of cherimoya which value chains in South American countries have been recently studied (Vanhove \& van Damme 2013). The presence of interspecific hybrids and the lack of flowers and fruits during most of the year make rapid unequivocal identification of these species difficult in the field, hindering studies in different areas such as diversity evaluation and germplasm collection, conservation and management. Consequently a fast and reliable molecular method for identification of closely related species of Annona will be an important advance in those kinds of studies.

One of the best approaches to unequivocally identify species from leaf samples collected in the field is the use of DNA barcoding techniques. DNA barcoding aims to the adoption, in a great scale, of a few short standardized genome portions that allows a complete species identification and discrimination, especially in cases where morphological identification is difficult. In 2004 the international initiative Consortium for the Barcode of Life (CBOL) was founded for the development of a global method for the identification of plant and animal species. Six years later, the International Barcode of Life (iBOL) was activated for the maintenance of the barcode reference library BOLD (Barcode of Life Data systems) (Ratnasingham \& Hebert 2007; Bhargava \& Sharma 2013). Since Hebert et al. (2003) proposed the mitochondrial gene cytochrome c oxidase 1 (CO1) as the barcode for animal species, it has been widely used (Hebert et al. 2003; Nicolas et al. 2012). In the case of plants, the CBOL Plant Working Group recommended a two locus combination of the 
chloroplast ribulose-1, 5-bisphosphate carboxylase/oxygenase large subunit gene ( $r b c \mathrm{~L})$ and maturase $\mathrm{K}$ gene (matK) as the core barcode (CBOL Plant Working Group 2009). However, in some cases those two markers produce incomplete species resolution, especially in closely related taxa (Zhang et al. 2012) or recently diverged species (van Velzen et al. 2012). Consequently, the use of additional genome portions such as the internal transcribed spacer (ITS) and the second internal transcribed spacer (ITS2) from nuclear ribosomal DNA or the chloroplast trnH-psbA intergenic spacer have been proposed (Kress et al. 2005; Chen et al. 2010; China Plant BOL Group et al. 2011; Hollingsworth 2011; Pang et al. 2012). In addition, the complete chloroplast genome is increasingly being used as super-barcode due to its species discrimination power, resolving some problems derived from the single or multiple loci barcode techniques (Li et al. 2015).

In order to have a fast and reliable method to discern between closely related Annona species with agronomic interest, in this work we developed species specific primers to unequivocally differentiate the seven most common agronomically interesting Annona species present in Central and South America (Annona cherimola, A. reticulata, A. squamosa, $A$. muricata, A. macroprophyllata, $A$. glabra and $A$. purpurea) based on newly sequenced data. The sequences were validated in 6 additional species of Annona and in an interspecific hybrid. The discrimination power of the most used plant barcode genes ( $r b c \mathrm{~L}$ and matK) was tested, using also additional Annona sequences available in the BOLD database and new sequences obtained were registered in the GenBank data base web page.

Table 1.1. Information of the plant material used. GB code refers to the code of the Germplasm Bank for the ex situ conserved material; "wild" stands for accessions not conserved ex situ.

\begin{tabular}{lllllll}
\hline Species & $\begin{array}{l}\text { Article } \\
\text { Code }\end{array}$ & $\begin{array}{l}\text { GB } \\
\text { code }\end{array}$ & $\begin{array}{l}\text { Country of orin } \\
\text { origin }\end{array}$ & $\begin{array}{l}\text { Coordinates } \\
\text { (Long/Lat) }\end{array}$ & $\begin{array}{l}\text { matK } \\
\text { (GenBank) }\end{array}$ & $\begin{array}{l}\text { rbcL } \\
\text { (GenBank) }\end{array}$ \\
\hline A. cherimola & Che1 & FDJ & Spain & $-4.0438 / 36.7601$ & KM068846 & KM068867 \\
A. cherimola & Che2 & SP74 & Peru & $-4.0439 / 36.7604$ & KM068847 & KM068868 \\
A. cherimola & Che3 & Wild & Honduras & $-88.1799 / 14.3122$ & KM068848 & KM068869 \\
A. reticulata & Ret1 & Wild & Honduras & $-88.5938 / 14.5798$ & KM068849 & KM068870 \\
A. reticulata & Ret2 & Wild & Honduras & $-87.1867 / 14.5683$ & KM068850 & KM068871 \\
A. reticulata & Ret3 & Wild & Guatemala & $-90.0005 / 14.9112$ & KM068851 & KM068872 \\
A. squamosa & Squ1 & Aus2 & Australia & $-4.0416 / 36.758$ & KM068852 & KM068873 \\
A. squamosa & Squ2 & Asquts & Unknown & $-4.0412 / 36.7544$ & KM068853 & KM068874 \\
A. squamosa & Squ3 & Wild & Honduras & $-87.6429 / 14.5645$ & KM068854 & KM068875 \\
A. muricata & Mur1 & Amur1 & Unknown & $-4.0415 / 36.758$ & KM068855 & KM068876 \\
A. muricata & Mur2 & Wild & Honduras & $-87.2141 / 14.0768$ & KM068856 & KM068877 \\
A. muricata & Mur3 & Wild & Guatemala & $-90.8859 / 14.1061$ & KM068857 & KM068878 \\
A. macroprophyllata & Mac1 & Amacro3 & Honduras & $-4.0421 / 36.7612$ & KM068858 & KM068879 \\
A. macroprophyllata & Mac2 & Wild & Honduras & $-88.9366 / 14.5584$ & KM068859 & KM068880
\end{tabular}




\begin{tabular}{|c|c|c|c|c|c|c|}
\hline A. macroprophyllata & Mac3 & Wild & Guatemala & $-91.7571 / 15.8353$ & KM068860 & KM068881 \\
\hline A. glabra & Gla1 & Agla2 & Unknown & $-4.0418 / 36.7584$ & KM068861 & KM068882 \\
\hline A. glabra & Gla2 & Wild & Honduras & $-88.8661 / 15.1714$ & KM068862 & KM068883 \\
\hline A. glabra & Gla3 & Agla4 & Unknown & $-4.0421 / 36.7611$ & KM068863 & KM068884 \\
\hline A. purpurea & Pur1 & Wild & Honduras & $-87.6564 / 14.606$ & KM068864 & KM068885 \\
\hline A. purpurea & Pur2 & Wild & Honduras & $-87.9475 / 14.6854$ & KM068865 & KM068886 \\
\hline A. purpurea & Pur3 & Wild & Costa Rica & $-84.95 / 10.7833$ & KM068866 & KM068887 \\
\hline A. liebmanniana & Lie1 & Wild & Honduras & $-87.4365 / 15.7968$ & & \\
\hline A. longiflora & Lon1 & MA25S1 & Mexico & $-4.0422 / 36.7611$ & & \\
\hline A. montana & Mon1 & Amon1 & Unknown & $-4.0418 / 36.7584$ & & \\
\hline A. senegalensis & Sen1 & Asen 1 & Unknown & $-4.0419 / 36.7612$ & & \\
\hline A. emarginata & Ema1 & Aema21 & Paraguay & $-4.0421 / 36.761$ & & \\
\hline A. neosalicifolia & Sal1 & Aneo20 & Paraguay & $-4.0412 / 36.7597$ & & \\
\hline Atemoya & Ate1 & JT3 & $\begin{array}{l}\text { Breeding } \\
\text { material }\end{array}$ & $-4.0412 / 36.7547$ & & \\
\hline Atemoya & Ate2 & JT7 & $\begin{array}{l}\text { Breeding } \\
\text { material }\end{array}$ & $-4.0411 / 36.7548$ & & \\
\hline Atemoya & Ate3 & JT153 & $\begin{array}{l}\text { Breeding } \\
\text { material }\end{array}$ & $-4.0413 / 36.7545$ & & \\
\hline Atemoya & Ate4 & Ate Roja & $\begin{array}{l}\text { Breeding } \\
\text { material }\end{array}$ & $-4.0415 / 36.758$ & & \\
\hline Atemoya & Ate5 & 19Joy & $\begin{array}{l}\text { Breeding } \\
\text { material }\end{array}$ & $-4.042 / 36.7552$ & & \\
\hline
\end{tabular}

\section{MATERIALS AND METHODS}

\section{Plant Material}

Leaves from three different genotypes of each of seven Annona species (Annona cherimola, A. reticulata, A. squamosa, A. muricata, A. macroprophyllata, A. glabra, and A. purpurea) were sampled in order to detect intraspecific variability. The materials were either collected from the wild or from an ex situ Annona germplasm collection maintained at the IHSM-UMACSIC in Málaga (Spain) at latitude $36^{\circ} 45^{\prime} \mathrm{N}$, longitude $4^{\circ} 4^{\prime} \mathrm{W}$ and altitude $35 \mathrm{~m}$ above sea level. Their geographic origin and codes are described in Table 1.1. All trees were previously identified in the field using morphological characters. Leaf samples from 6 additional Annona species (A. liebmanniana Baill., A. longiflora S. Watson, A. montana Macfad., A. senegalensis Pers., A. emarginata (Schltdl.) H. Rainer, and $A$. neosalicifolia H. Rainer.) and 5 atemoya hybrids ( $A$. cherimola $\times$ A. squamosa), were used in order to test the validity of the primers generated (Table 1.1). 


\section{DNA Extraction, PCR Amplification, Visualization and Sequencing}

Plant DNA extraction was performed from $50 \mathrm{mg}$ of young leaf tissue by a modified CTAB method (Viruel \& Hormaza 2004). Each PCR reaction contained $16 \mathrm{mM}(\mathrm{NH} 4) 2 \mathrm{SO} 4,67 \mathrm{mM}$ Tris-ClH pH 8.8, 0.01\% Tween-20, $3 \mathrm{mM} \mathrm{MgCl} 2,0.1 \mathrm{mM}$ each dNTP, $0.3 \mu \mathrm{M}$ each primer, 20 ng genomic DNA and 1 unit of BioTaq ${ }^{\text {TM }}$ DNA polymerase (Bioline, London, UK) in a final volume of $15 \mu \mathrm{l}$. For sequencing the final volume was increased to $35 \mu \mathrm{l}$ maintaining the concentration of the different ingredients. Universal primers used to amplify $r b c L$ were rbcLaF and rbcLaR, for matK MatK_1RKim-f and MatK_3FKim-r (Kuzmina \& Ivanova 2011). For rbcL the temperature profile was: an initial step of $4 \mathrm{~min}$ at $95^{\circ} \mathrm{C}, 5$ cycles of $30 \mathrm{~s}$ at $94^{\circ} \mathrm{C}, 1 \mathrm{~min}$ at $55^{\circ} \mathrm{C}$ and $1 \mathrm{~min}$ at $72^{\circ} \mathrm{C}, 30$ cycles of $30 \mathrm{~s}$ at $94^{\circ} \mathrm{C}, 1 \mathrm{~min}$ at $54^{\circ} \mathrm{C}$ and $1 \mathrm{~min}$ at $72^{\circ} \mathrm{C}$ and a final step of $10 \mathrm{~min}$ at $72^{\circ} \mathrm{C}$. For matK the temperature profile was: an initial step of $1 \mathrm{~min}$ at $94^{\circ} \mathrm{C}, 35$ cycles of $30 \mathrm{~s}$ at $94^{\circ} \mathrm{C}, 20 \mathrm{~s}$ at $52^{\circ} \mathrm{C}$ and $50 \mathrm{~s}$ at $72^{\circ} \mathrm{C}$ and a final step of $5 \mathrm{~min}$ at $72^{\circ} \mathrm{C}$. PCRs were carried out in an I-cycler (Bio-Rad Laboratories, Hercules, CA, USA) thermocycler using the following temperature profile: an initial step of $1 \mathrm{~min}$ at $94^{\circ} \mathrm{C}, 35 \mathrm{cycles}$ of $30 \mathrm{~s}$ at $94^{\circ} \mathrm{C}, 30 \mathrm{~s}$ at $60-69^{\circ} \mathrm{C}($ Table 1.2$)$, and $1 \mathrm{~min}$ at $72^{\circ} \mathrm{C}$, and a final step of $5 \mathrm{~min}$ at $72^{\circ} \mathrm{C}$. Amplicons were visualized in 1 or $3 \%$ agarose gels stained with Gel Red (1X).

Two multiplex PCR methods were developed for 6 of the 7 specific markers, depending on their annealing temperature. At $65^{\circ} \mathrm{C}$, primers $\mathrm{AChF} 1, \mathrm{AChR} 1, \mathrm{AChReF} 1$, AReR1, AMuF1, AMuR1 were placed in the same master PCR mix, only decreasing the concentration of $\mathrm{AChF} 1$ and $\mathrm{AChR} 1$ from 0.3 to $0.07 \mu \mathrm{M}$. At $69^{\circ} \mathrm{C}$, primers ASquF1, ASquR1, AMaF1, AMaR1, AGlaF1, AGlaR1 were also used together increasing every concentration from 0.3 to $0.4 \mu \mathrm{M}$. Prior to sequencing, PCR solutions were purified with NucleoSpin $\AA$ Extract II (Macherey-Nagel). Sequencing was done by the fluorescent dye terminator sequencing method (Macrogen).

\section{Barcode Sequence Quality and Species Discrimination}

Amplified matK and rbcL of the 21 different Annona DNA samples belonging to 7 species were sequenced in the forward direction. Chromatograms were analyzed by Chromas Lite version 2.1 (2012), Technelysium Pty Ltd, South Brisbane, Queensland, Australia. The criteria used to establish an acceptable sequence were as follows (modified from Hanner 2009): (i) ends were trimmed to minimize low quality base calls on each end; all bases were deleted until there were at least contiguous 10 pair bases with a PHRED score $>20$ (ii) bases with PHRED values less than 20 were recorded as $\mathrm{N}$; (iii) sequences with more than $40 \% \mathrm{~N}$ base calls were deleted. 
To assess the discriminatory power of both genes at the specific level, the 42 sequences obtained, 21 of matK and 21 of $r b c L$, were aligned with MUSCLE implemented in the software MEGA5 version 5.05 (Tamura et al. 2011) using the default options.

Table 1.2. Details of the primers designed for identification of species of Annona including sequence, PCR melting and annealing temperatures, expected PCR product size and target species.

\begin{tabular}{|c|c|c|c|c|c|c|}
\hline Name & Sense & Sequence $5^{\prime}-3^{\prime}$ & $\begin{array}{l}\text { Melting } \\
\left.\text { temp. ( }{ }^{\circ} \mathrm{C}\right)\end{array}$ & $\begin{array}{l}\text { Annealing } \\
\text { temp. }\left({ }^{\circ} \mathrm{C}\right)\end{array}$ & $\begin{array}{l}\text { Expected } \\
\text { size (bp) }\end{array}$ & Specificity \\
\hline AChF1 & $\mathrm{F}$ & GTATATGAATGTGAATCGGTATTC & 58.3 & \multirow{2}{*}{65} & \multirow{2}{*}{396} & \multirow{2}{*}{$\begin{array}{l}\text { A. cherimola } \\
\text { matK }\end{array}$} \\
\hline AChR1 & $\mathrm{R}$ & TTGACTCCTTACTGCGGAAT & 61.7 & & & \\
\hline AChReF1 & $\mathrm{F}$ & GCTTCGGAATGATTTTCC & 60.1 & \multirow{2}{*}{65} & \multirow{2}{*}{364} & \multirow{2}{*}{$\begin{array}{l}\text { A. reticulata } \\
\text { matK }\end{array}$} \\
\hline AReR1 & $\mathrm{R}$ & CGCCTTAGCCAACGATT & 61.9 & & & \\
\hline $\mathrm{ASqF} 1$ & $\mathrm{~F}$ & CCATTTCCGTTTGTTCAAAC & 62.2 & \multirow{2}{*}{69} & \multirow{2}{*}{315} & \multirow{2}{*}{$\begin{array}{l}\text { A. squamosa } \\
\text { matK }\end{array}$} \\
\hline ASqR1 & $\mathrm{R}$ & GGTAAGATTTCCATTTCTTCATC & 59.8 & & & \\
\hline AMuF1 & $\mathrm{F}$ & CATTTACGATCAACATCCTTTA & 58.6 & \multirow{2}{*}{65} & \multirow{2}{*}{332} & \multirow{2}{*}{$\begin{array}{l}\text { A. muricata } \\
\text { matK }\end{array}$} \\
\hline AMuR1 & $\mathrm{R}$ & GAAGAATTTTGGCGTACACTTA & 60.2 & & & \\
\hline AMaF1 & $\mathrm{F}$ & ATACAAGATGCTCCCTCTTTG & 60.2 & \multirow[b]{2}{*}{69} & \multirow[b]{2}{*}{644} & \multirow{2}{*}{$\begin{array}{l}\text { A. macro- } \\
\text { prophyllata } \\
\text { matK }\end{array}$} \\
\hline AMaR1 & $\mathrm{R}$ & TTAGCCAATGATCCAATCATT & 61.2 & & & \\
\hline AGIF1 & $\mathrm{F}$ & CGATCAACATCCTTTGGG & 62.1 & \multirow{2}{*}{69} & \multirow{2}{*}{476} & \multirow{2}{*}{ A. glabra matK } \\
\hline AGIR1 & $\mathrm{R}$ & GCCGGCTTACTAATAGGGTT & 61.3 & & & \\
\hline APuF1 & $\mathrm{F}$ & TTCTTGTTCCTATATAATATTCATA & 53.2 & \multirow{2}{*}{61} & \multirow{2}{*}{619} & \multirow{2}{*}{$\begin{array}{l}\text { A.purpurea } \\
\text { matK }\end{array}$} \\
\hline APuR1 & $\mathrm{R}$ & GAGAAAGATTTCTGTATATGCGT & 58.5 & & & \\
\hline 1R_kim & $\mathrm{F}$ & ACCCAGTCCATCTGGAAATCTTGGTTC & & \multirow{2}{*}{\multicolumn{2}{|c|}{52}} & \multirow{2}{*}{ Universal matK } \\
\hline 3F_kim & $\mathrm{R}$ & CGTACAGTACTTTTGTGTTTACGAG & & & & \\
\hline rbcLa_F & $\mathrm{F}$ & ATGTCACCACAAACAGAGACTAAAGC & & \multirow{2}{*}{$55-54$} & & \multirow{2}{*}{ Universal rbcL } \\
\hline rbcLa $R$ & $\mathrm{R}$ & GTAAAATCAAGTCCACCRCG & & & & \\
\hline
\end{tabular}

Pairwise sequence distances were calculated using the Kimura-2-parameter (K2P) that takes into account transitions and transversions, with the same software (Aubriot et al. 2013). For each species, when the maximum intraspecific distance was lower than the minimum interspecific distance, discrimination was considered successful (CBOL Plant Working Group 2009). In addition, a tree based identification approach was used. For that, all sequences of the genus Annona available in BOLD for each of the two genes analyzed were downloaded [access 08/2012] (Ratnasingham \& Hebert 2007); in total 20 sequences of matK belonging to 10 different species and 36 sequences of $r b c L$ belonging to 24 different species were available (Table 1.3). Two Neighbor Joining (NJ) trees of K2P distances were constructed using the same program and running 1000 bootstrap replicates (Figure 1.1). 


\section{Design of Species-specific Markers}

In order to design PCR-specific primers, newly sequenced alignments for matK and rbcL Annona DNA samples and the sequences downloaded from BOLD were used. Inter-species polymorphisms were studied manually using GENEDOC version 2.7. Intraspecific variations were not considered. The gene matK was selected for the development of 7 Annona specific markers. Pairs of specific primers were designed locating the $3^{\prime}$ end of each primer in specific shared polymorphic regions compared to the sequences that belonged to all the other species. Primers were designed to amplify targets of different length so PCR output could be determined by its position in a gel. To calculate melting temperatures and avoid as much as possible interaction among primers (also within different markers) we used the Multiple Primer Analyzer available at http://www.thermoscientificbio.com/webtools/multipleprimer [access 02/2013]. Primers designed are described in Table 1.2 and were validated in 6 additional Annona species through PCR amplification of DNA and visualization of the amplification fragments in agarose gels.

Table 1.3. MatK and rbcL BOLD sequences downloaded from http://www.boldsystems.org/

\begin{tabular}{llllll}
\hline BOLD Code & Code & Species & rbcL (bp) & matK (bp) & Collected in \\
\hline GBVG4966-11 & AcuA & A. acuminata & & 566 & Panama \\
GBVG4967-11 & AcuB & A. acuminata & 553 & & Panama \\
GBVG4968-11 & AmaA & A. amazonica & 1317 & & Bolivia \\
GBVG4969-11 & BicA & A. bicolor & 1369 & & Mexico \\
GBVG4970-11 & CorA & A. cornifolia & 684 & & Bolivia \\
GBVG4971-11 & DecA & A. deceptrix & 1427 & & Ecuador \\
GBVG4972-11 & DemA & A. deminuta & 1291 & & Peru \\
GBVG4973-11 & DumA & A.dumetorum & & \multirow{2}{*}{978} & - \\
GBVG4974-11 & DumB & A.dumetorum & 1368 & & Dominican Republic \\
GBVG4975-11 & GlaA & A. glabra & & 831 & United States \\
GBVG4976-11 & GlaB & A. glabra & 1427 & & United States \\
GBVG4977-11 & GlaC & A. glabra & & 1524 & - \\
GBVG4978-11 & HolA & A. holosericea & 1369 & & Honduras \\
GBVG4979-11 & HypA & A. hypoglauca & 1369 & & Bolivia \\
GBVG4980-11 & MonA & A. montana & 1369 & & - \\
GBVG4981-11 & MurA & A. muricata & & \multirow{2}{*}{1524} & - \\
GBVG4982-11 & MurB & A. muricata & 1400 & & - \\
GBVG4983-11 & MurC & A. muricata & & 831 & - \\
GBVG4984-11 & MurD & A. muricata & 1421 & & - \\
GBVG4985-11 & OliA & A. oligocarpa & 1269 & & Ecuador \\
GBVG4986-11 & PruA & A. pruinosa & 1369 & & Costa Rica
\end{tabular}




\begin{tabular}{llllll} 
GBVG4987-11 & RetA & A. reticulata & 1369 & & Bolivia \\
GBVG4988-11 & ScaA & A. scandens & 676 & & Bolivia \\
GBVG4989-11 & SclA & A. sclerophylla & & 1524 & - \\
GBVG4990-11 & SenA & A. senegalensis & 1426 & & - \\
GBVG4991-11 & SprA & A. spraguei & & 783 & Panama \\
GBVG4992-11 & SprB & A. spraguei & 550 & & Panama \\
GBVG4993-11 & SquA & A. squamosa & & 842 & - \\
GBVG4994-11 & SquB & A. squamosa & 1369 & & Netherlands Antilles \\
GBVG4995-11 & SymA & A. symphyocarpa & 1343 & & Guyana \\
GBVG4996-11 & UrbA & A. urbaniana & 1369 & & Dominican Republic \\
INB080-12 & MucA & A. mucosa & 552 & & Costa Rica \\
KNPA853-09 & SenB & A. senegalensis & 555 & 1056 & South Africa \\
MHPAC1050-11 & HolB & A. holosericea & 552 & & Costa Rica \\
MHPAC1051-11 & HolC & A. holosericea & 552 & & Costa Rica \\
MHPAC1052-11 & HolD & A. holosericea & 552 & & Costa Rica \\
MHPAC370-08 & RetB & A. reticulata & 553 & 1006 & Costa Rica \\
MHPAC371-08 & RetC & A. reticulata & 552 & 1006 & Costa Rica \\
MHPAC378-08 & RetD & A. reticulata & 552 & 975 & Costa Rica \\
MHPAC397-08 & PurA & A. purpurea & 551 & 1006 & Costa Rica \\
MHPAC398-08 & PurB & A. purpurea & 552 & 1006 & Costa Rica \\
MHPAC399-08 & PurC & A. purpurea & 552 & 1006 & Costa Rica \\
MHPAD3022-10 & GlaD & A. glabra & 552 & 1006 & Costa Rica \\
MHPAD3023-10 & GlaE & A. glabra & & 1006 & Costa Rica \\
MHPAD3024-10 & GlaF & A. glabra & 552 & 995 & Costa Rica \\
MHPAD3025-10 & GlaG & A. glabra & 552 & 1006 & Costa Rica \\
\hline
\end{tabular}




\section{RESULTS}

\section{Barcode Sequences Quality and Species Discrimination}

All of the 42 sequences obtained fulfilled the established criteria to consider the sequencing reactions successful. Sequence sizes after the trimming process varied from 752 to $820 \mathrm{bp}$ in the case of matK and from 470 to 528 in the case of rbcL. The number of bases with a PHRED score below 20, so, therefore, substituted by $\mathrm{N}$, was between 0 and 7 , with the exception of sample Mur2 amplified with matK primers which had 61 bad quality bp (less of $40 \%$ of the sequence). All sequences were uploaded to the GenBank database and their accession numbers are indicated in Table 1.1.

Intraspecific sequence variability was only found in A. muricata. The maximum intraspecific distance was then compared to the minimum interspecific distance; in almost all cases the former was smaller than the latter (Table 1.4). Nucleotide sequence of the barcode gene matK could discriminate all 7 species, while $r b c L$ could not distinguish between $A$. cherimola and $A$. squamosa samples.

The NJ trees obtained are shown in Figure 1.1 In the matK tree, new sequences from the 7 tested species grouped in different clusters. Besides, where applicable, sequences from the same species (newly obtained in this work and downloaded from BOLD) grouped together. In the case of rbcL, all the 21 new sequences clustered by species except $A$. cherimola and $A$. squamosa, that were grouped together. Furthermore, sequences from the same species downloaded from BOLD and the newly obtained sequences grouped together in the same cluster. Nevertheless, some species were mixed; in the cluster of $A$. cherimola and $A$. squamosa samples, three additional species ( $A$. urbaniana, $A$. reticulata and $A$. pruinosa) downloaded from BOLD were present $A$. holosericea and $A$. spraguei BOLD samples appeared also in the same cluster. 


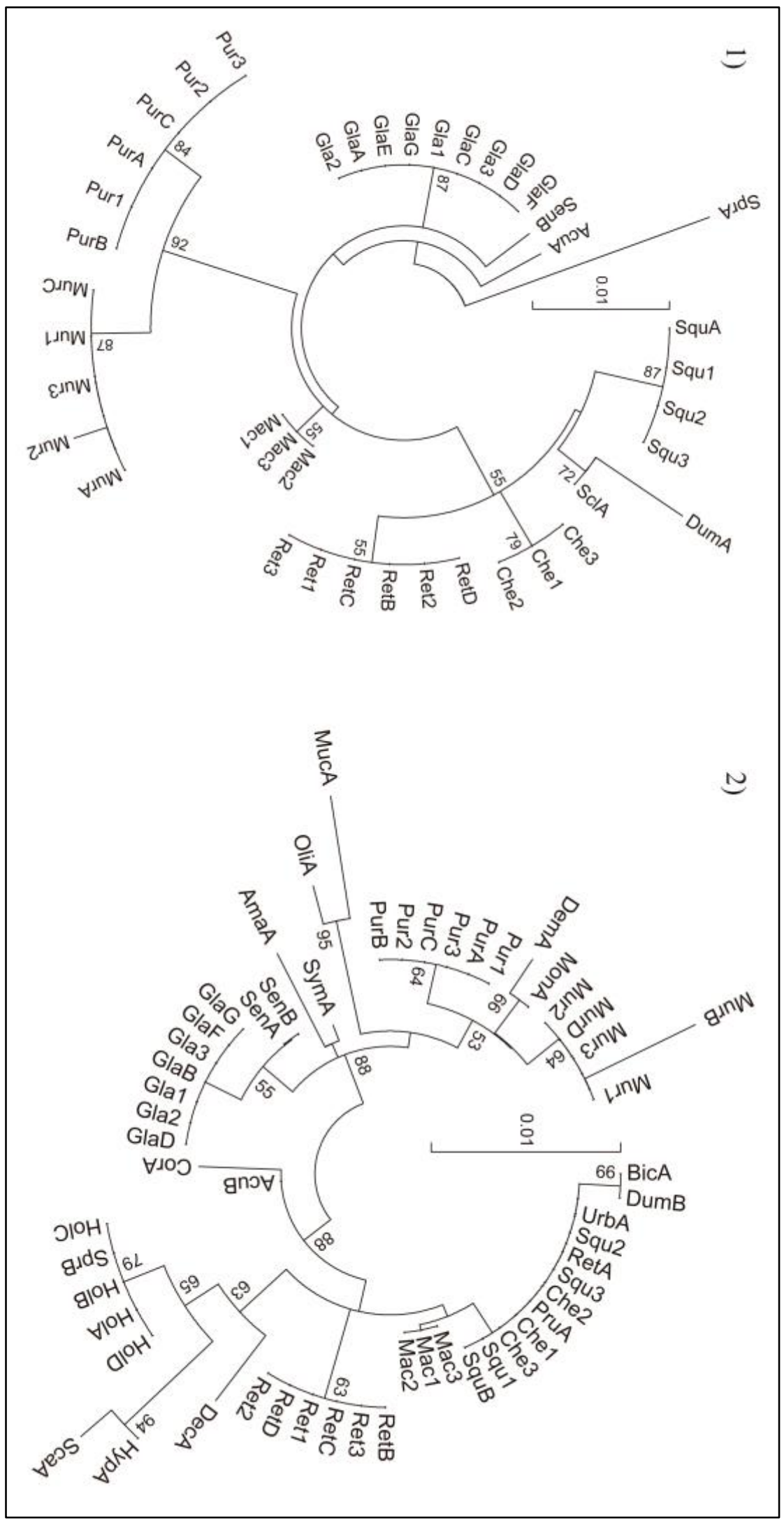

Figure 1.1. Neighbour joining trees of pairwise K2P substitution rates using 41 matK sequences (1) and $57 \mathrm{rbcL}$ sequences (2). Taxon codes are indicated in Table 1.1 and Table 1.3. Bootstrap values of $50 \%$ and above are shown on the clusters. The scale bar represents the substitution rate per site. 
Table 1.4. Intra- and interspecific 2KP distances among the new sequences obtained.

\begin{tabular}{|c|c|c|c|c|c|c|c|c|}
\hline \multirow{3}{*}{ Species (codes) } & \multicolumn{4}{|l|}{ matK } & \multicolumn{4}{|l|}{$r b c L$} \\
\hline & \multicolumn{2}{|c|}{$\begin{array}{l}\text { Intraspecific } \\
\text { distances }\end{array}$} & \multicolumn{2}{|c|}{$\begin{array}{l}\text { Interspecific } \\
\text { distances }\end{array}$} & \multicolumn{2}{|c|}{$\begin{array}{l}\text { Intraspecific } \\
\text { distances }\end{array}$} & \multicolumn{2}{|c|}{$\begin{array}{l}\text { Interspecific } \\
\text { distances }\end{array}$} \\
\hline & Min & Max & Min & Max & $\overline{M i n}$ & Max & Min & Max \\
\hline $\begin{array}{l}\text { A. cherimola } \\
\text { (Che1, Che2, Che3) }\end{array}$ & 0.000 & 0.000 & 0.008 & 0.023 & 0.000 & 0.000 & 0.000 & 0.013 \\
\hline $\begin{array}{l}\text { A. reticulata } \\
\text { (Ret1, Ret2, Ret3) }\end{array}$ & 0.000 & 0.000 & 0.009 & 0.024 & 0.000 & 0.000 & 0.002 & 0.015 \\
\hline $\begin{array}{l}\text { A. squamosa } \\
\text { (Squ1, Squ2, Squ3) }\end{array}$ & 0.000 & 0.000 & 0.008 & 0.021 & 0.000 & 0.000 & 0.000 & 0.013 \\
\hline $\begin{array}{l}\text { A. muricata } \\
\text { (Mur1, Mur2, Mur3) }\end{array}$ & 0.000 & 0.001 & 0.009 & 0.023 & 0.000 & 0.000 & 0.004 & 0.015 \\
\hline $\begin{array}{l}\text { A. macroprophyllata } \\
\text { (Mac1, Mac2, Mac3) }\end{array}$ & 0.000 & 0.000 & 0.011 & 0.023 & 0.000 & 0.000 & 0.002 & 0.023 \\
\hline $\begin{array}{l}\text { A. glabra } \\
\text { (Gla1, Gla2, Gla3) }\end{array}$ & 0.000 & 0.000 & 0.014 & 0.018 & 0.000 & 0.000 & 0.009 & 0.018 \\
\hline $\begin{array}{l}\text { A. purpurea } \\
\text { (Pur1, Pur2, Pur3) }\end{array}$ & 0.000 & 0.000 & 0.009 & 0.024 & 0.000 & 0.000 & 0.009 & 0.024 \\
\hline
\end{tabular}

\section{Specific Markers}

Seven markers were developed for 7 different Annona species. Details on the primer features and amplification conditions are summarized in Table 1.2. Primer specificity was verified using 13 samples of different Annona species (Figure 1.2). For each species, just one band appeared when the specific markers developed were used.

In order to optimize routine species identification two multiplex PCR methods were developed; one for A. squamosa, A. macroprophyllata and A. glabra markers (all with $69^{\circ} \mathrm{C}$ annealing temperature), whose expected size amplicons are 315, 644, and 476 bp respectively and the other, for $A$. cherimola, $A$. muricata and $A$. reticulata markers (all with $65^{\circ} \mathrm{C}$ annealing temperature), whose expected size amplicons are 396, 332, and $364 \mathrm{bp}$ respectively. In addition, AChReF1 hybridizes with $A$. cherimola sequences so, when added to the same reaction than the AChR1 markers, a new band of $271 \mathrm{bp}$ appeared in the $A$. cherimola samples (Figure 1.3). 


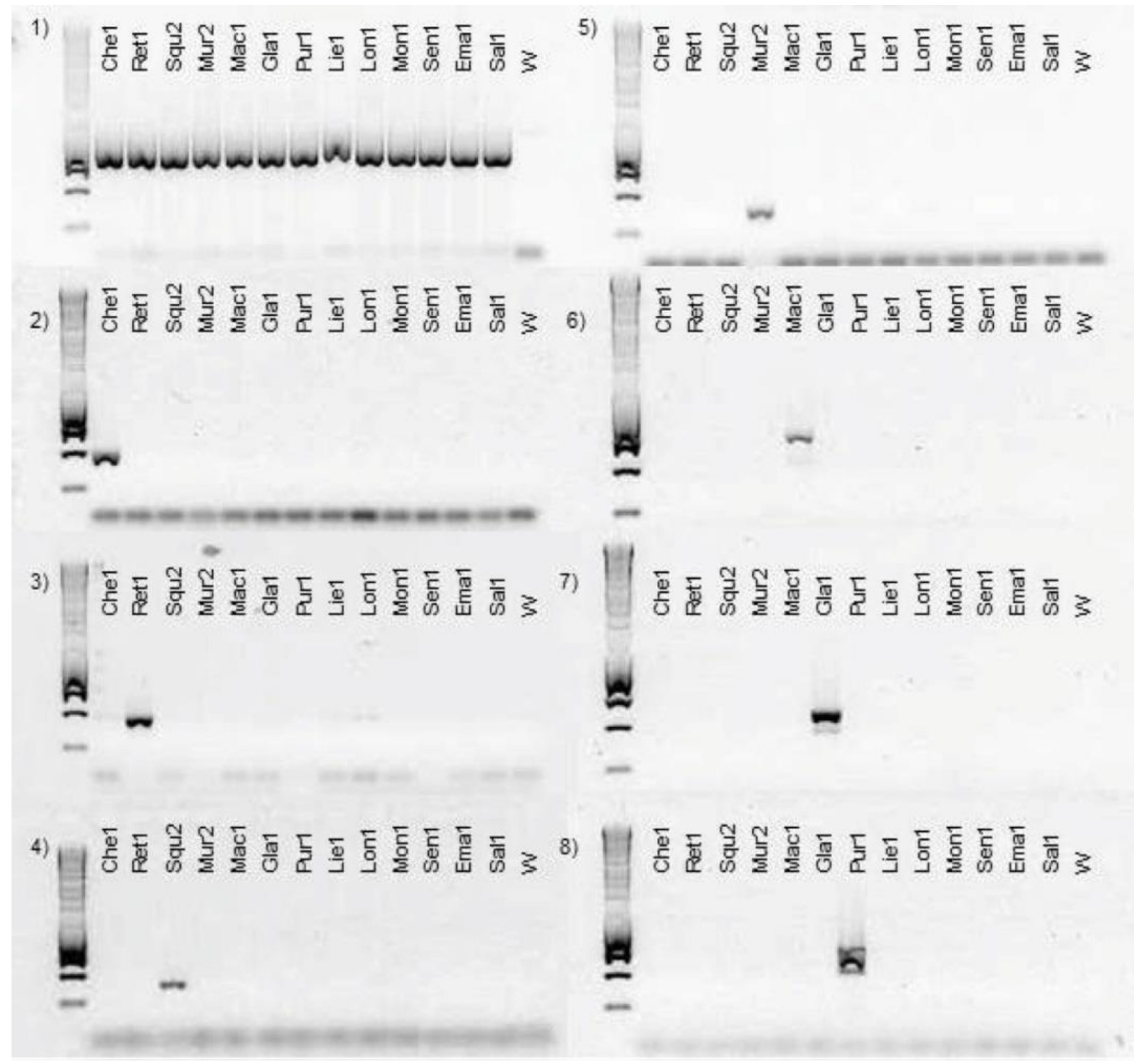

Figure 1.2. Electrophoresis in $1 \%$ agarose gels of specific PCR reactions using the primers developed in this work and 13 DNA samples from different species in the Annonaceae. Taxon codes are indicated in Table 1.1. W: water. 1) PCR with universal matK primers, 2) PCR with A. cherimola primers, 3) PCR with $A$. reticulata primers, 4) PCR with $A$. squamosa primers, 5) PCR with $A$. muricata primers, 6) PCR with A. macroprophyllata primers, 7) PCR with A. glabra primers, 8) PCR with $A$. purpurea primers. Hiperladder $1 \mathrm{~Kb}$ of Bioline was used as size marker.

These markers could also be used to study interspecific hybrids. Five atemoya samples, a hybrid of $A$. cherimola and $A$. squamosa, were analyzed with both loci. Four of the hybrid atemoyas where known to have $A$. cherimola as maternal parent and, as expected, those 4 samples only showed amplification bands when amplified with the $A$. cherimola specific primers (Figure 1.4). The fifth sample, for which the direction of the cross was unknown, also showed this band when amplified with the $A$. cherimola specific marker, indicating $A$. squamosa as the pollen donor. 


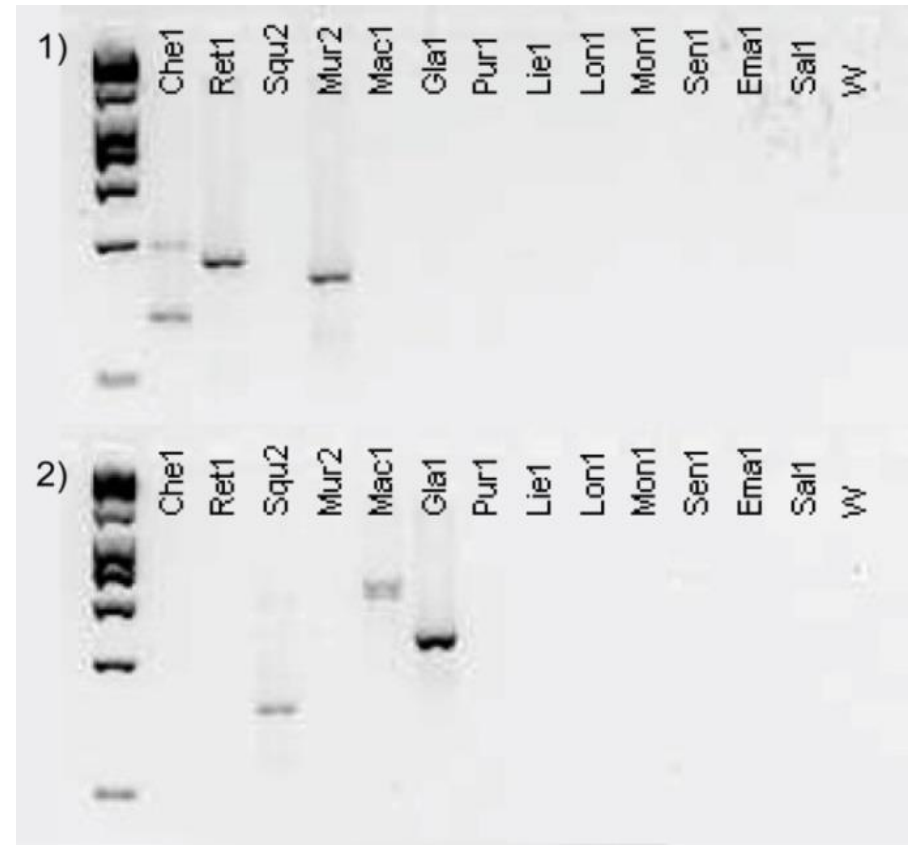

Figure 1.3. Electrophoresis in $3 \%$ agarose gel of 2 multiplex PCR. Taxon codes are indicated in Table 1.1. W: water. 1) Multiplex PCR with $A$. cherimola, $A$. reticulata and $A$. muricata primers. 2) Multiplex PCR with A. squamosa, A. macroprophyllata and $A$. glabra primers. Hiperladder $1 \mathrm{~Kb}$ of Bioline was used as size marker.

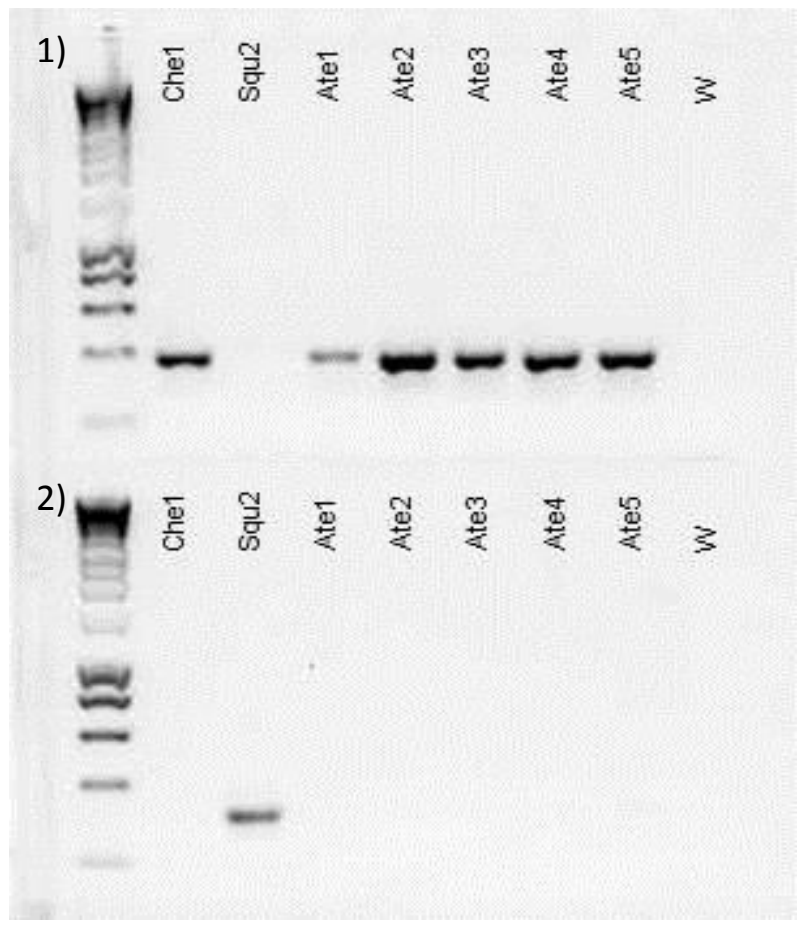

Figure 1.4. Electrophoresis in $1 \%$ agarose gel of 1) $A$. cherimola and 2) $A$. squamosa primers with atemoya DNA samples. Taxon codes are indicated in Table 1.1. W: water. Hiperladder $1 \mathrm{~Kb}$ of Bioline was used as size marker. 


\section{DISCUSSION}

In this work we tested the two chloroplast loci, rbcL and matK, proposed for the barcode of plants by the CBOL (CBOL Plant Working Group 2009), for differentiation of species of agronomic interest in the genus Annona. Sequences of other species of the genus present in the BOLD database were also included in the analysis. The results obtained by distance analysis methods with 21 genotypes belonging to 7 agronomical important Annona species showed almost no intraspecific variation, which could be due to the limited number of samples analyzed. One criticism of this kind of analyses is that often a very few individuals per species are studied or that incomplete geographic sampling is performed resulting in possible poor representation of the intraspecific variation or interspecific divergence, given rise to possible misleading results regarding barcoding gap and overlap between intra- and interspecific variation (Meyer \& Paulay 2005). Although for some species the samples used here were obtained from different geographical areas, in other species the samples used just cover a small part of their distribution range; consequently, additional intraspecific variation could be present if samples from other regions were included in the analysis. Locus $r b c L$ could distinguish 5 of the 7 species, showing overlap between intra- and interspecific variation, while locus matk could distinguish all of them, since intraspecific distances were smaller than interspecific values, showing a barcode gap with the number of species studied. Both rbcL and matK have been recommended as core plant barcodes by CBOL (CBOL Plant Working Group 2009) although, as shown in this work, rbcL usually displays a lower interspecific variation (Kress et al. 2005). Moreover, the universality of these two markers has been questioned in some particular taxa (Chase et al. 2007; Roy et al. 2010).

This initial analysis was broadened with comparison with additional sequences from other species of the genus Annona available in the BOLD database using NJ trees. Treebased methods are also used for the identification of query samples when comparing its barcode sequences to a data set and the clustering position analyzed (van Velzen et al. 2012). Results, again, show a good performance of both genes, particularly of matK, since sequences from different individuals of the same species were grouped together in different clusters of the $\mathrm{NJ}$ tree. The mixed presence of some species in the $\mathrm{NJ}$ trees could be explained by this lower identification power of $r b c L$ (when this number of different species is used) or by errors in species identification prior to uploading the sequences to the BOLD database. A multilocus analysis was not carried out since matK could discriminate all the species studied.

Newly obtained and BOLD matK sequences alignment was also used for the manual finding of specific polymorphic nucleotides. These were used for the development of 7 specific markers, relying on the idea of diagnostic positions. In fact, character-based 
diagnosis methods are the other big group used in traditional barcode techniques. They count just on relevant diagnostic positions of the sequence that would support a particular classification (DeSalle et al. 2005).

In the case of Annona species, the development of fast, reliable and economic tools, such as specific markers, to identify these promising subtropical resources in a very initial state of domestication is of great importance in order to optimize genetic resource management. In addition, since these markers are chloroplast based genes, their presence or absence in interspecific hybrids could serve to discern hybridization processes in these species; some of them are known to hybridize easily (such as $A$. cherimola and $A$. squamosa) although some authors (Zill \& Mahdeem 1998; George et al. 2002) have reported other hybrids in the genus (such as $A$. cherimola x A. reticulata or A. squamosa x A. diversifolia) at least as a result of artificial pollination. The markers described in this work are appropriate for the discrimination of the most important species of the genus from an agronomic point of view although, since the genus Annona includes about 160 species (Chatrou et al. 2012), additional work will be needed to develop appropriate identification tools for all the species of the genus. 


$$
\infty
$$




\title{
APPLICATION OF CHERIMOYA SPECIFIC MARKERS IN A GERMPLASM COLLECTION WITH GEOGRAPHICAL IMPLICATIONS ON ITS DIVERSITY AND DISPERSION
}

\begin{abstract}
Previously developed $A$. cherimola specific primers based on the plant barcode gene matK were tested in 296 cherimoya accessions from the word reference germplasm collection maintained at the IHSM-UMA-CSIC in Málaga (Spain) and in 250 cherimoya samples collected from three Central American countries (Honduras, Guatemala and Costa Rica). Results showed the existence of two different haplotypes in the samples analyzed with geographical correlation. A new marker that amplified all the samples analyzed was designed based on the trnL-F locus.
\end{abstract}

\section{INTRODUCTION}

Taxonomy is the discipline that identifies and classifies all organisms in categorical levels. Species is usually the smallest taxonomic category considered as lineages that evolve independently and, consequently, species identification is a crucial process for many different basic and applied research or management projects. The notion of species has been highly controversial and several different concepts have been proposed (Hey 2001, 2006). One of the most used, biological species concept, was developed by Mayr (1942) and defines species as groups of natural populations that mate really or potentially and are reproductively isolated from other groups. A phylogenetic concept defines species as a group of organisms descendent from a common ancestor that share certain primitive and derived characters (Cracraft 1983).

Both morphological and molecular (protein and nucleotide) characters have been used for the identification and classification of taxons, relying on the idea that linages diverge in the accumulation of variants. DNA based techniques provide some advantages in comparison to morphological or protein-based molecular techniques since DNA is a very stable molecule that provides a lot of information due to the degeneration of the genetic code and the high rate of mutation of non informative sites. Some of the molecular methods used for species identification are hybridization, restriction enzyme digestion, PCR-based techniques, real time PCR and analysis of nucleotide sequences (Pereira et al. 2008b) such as barcoding. In this sense, DNA barcoding is a taxonomic method whose final goals are to identify any species and to characterize new ones, comparing each species sequences against robust databases. Quite a few loci or a combination of them have been proposed for the barcode of plants; the most important are matK, $r b c \mathrm{~L}, t r n \mathrm{H}-p s b \mathrm{~A}$, trnL-F, ITS1, or ITS2, among others (CBOL Plant 
Working Group, 2009; Kress \& Erickson, 2007; De Groot et al. 2011; Hollingsworth 2011; China Plant BOL Group, 2011; Chen et al. 2010).

In a previous work (Larranaga \& Hormaza 2015, chapter 1), one of the combinations of two chloroplast loci (rbcL and matK) proposed for the barcode of plants (CBOL Plant Working Group, 2009), were tested in Annona species with significant agronomic interest. In addition, specific primers based on matK were designed to discriminate among them through a single PCR and observation of presence/absence bands in agarose electrophoresis gels. Annona cherimola, cherimoya, native to the Neotropics, is one of the most important species of agronomic interest in the Annonaceae family, although it is considered as a neglected and underutilized species (NUS) with a high agronomical potential in subtropical areas in different regions of the world (Bioversity International and CHERLA 2008). In order to test whether the primers designed for Annona cherimola included all the intraspecific variation, in this work 546 samples were analyzed, 410 were mapped and some of them were sequenced. A second set of primers was designed based on the trnL-F locus, used in several phylogenetic studies among the Annonaceae family (Chaowasku et al. 2014; Chatrou et al. 2012; Pirie et al. 2007; Richardson et al. 2004).

\section{MATERIAL AND METHODS}

\section{Plant material}

A total of 296 cherimoya accessions, conserved in the field germplasm collection maintained at the IHSM-UMA-CSIC, Spain, were collected. The number of samples per country of origin is indicated in Table 2.1. In addition, 250 samples collected in Guatemala (40), Honduras (137) and Costa Rica (73) were also analyzed. The design of new specific primers was carried out following Larranaga and Hormaza (2015) (chapter 1), two individuals belonging to each of the most important species of agronomical interest in the genus Annona ( $A$. cherimola Mill., A. reticulata L., A. squamosa L., A. muricata L., A. macroprophyllata Donn. Sm., A. glabra L. and A. purpurea Moc. \& Sessé ex Dunal) were selected. To validate these new primers, one individual of six additional Annona species (Annona liebmaniana, $A$. longiflora, A. montana, $A$. senegalensis, $A$. emarginata, and $A$. salicifolia) as well as one Asimina triloba individual were also analyzed. Codes and geographic origin of the individuals are indicated in Table 2.1.

\section{DNA extraction, amplification, visualization and sequencing}

Plant DNA extraction was performed from $50 \mathrm{mg}$ of young leaf tissue by a modified CTAB method (Viruel \& Hormaza 2004). Each PCR reaction contained $16 \mathrm{mM}\left(\mathrm{NH}_{4}\right)_{2} \mathrm{SO}_{4}, 67 \mathrm{mM}$ 


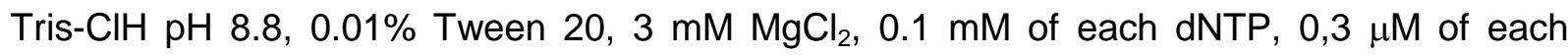
primer, $20 \mathrm{ng}$ of genomic DNA and 1 unit of BioTaq ${ }^{\mathrm{TM}}$ DNA polymerase (Bioline, London, UK) in a final volume of 15 or $35 \mu \mathrm{l}$. The analyzed loci are indicated in Table 2.2. PCR reactions were carried out in an I-cycler (Bio-Rad Laboratories, Hercules, CA, USA) using the following program: an initial step of $1 \mathrm{~min}$ at $94^{\circ} \mathrm{C}, 35$ cycles of $30 \mathrm{~s}$ at $94^{\circ} \mathrm{C}, 30 \mathrm{~s}$ at $60-66^{\circ} \mathrm{C}$ (Table 2.2) and $1 \mathrm{~min}$ at $72^{\circ} \mathrm{C}$ and a final step of $5 \mathrm{~min}$ at $72^{\circ} \mathrm{C}$. For matK the temperature profile was: an initial step of $1 \mathrm{~min}$ at $94^{\circ} \mathrm{C}, 35$ cycles of $30 \mathrm{~s}$ at $94^{\circ} \mathrm{C}, 20 \mathrm{~s}$ at $52^{\circ} \mathrm{C}$ and $50 \mathrm{~s}$ at $72^{\circ} \mathrm{C}$ and a final step of $5 \mathrm{~min}$ at $72^{\circ} \mathrm{C}$. Amplicons were visualized in $1 \%$ agarose gels stained with Gel Red (1X) and/or with a Beckman Coulter Genome LabTM GeXP capillary DNA analysis system after labeling forward primers with a fluorescent dye on the $5^{\prime}$-end. In this case, samples were denatured at $90^{\circ} \mathrm{C}$ for 120 seconds, injected at $2.0 \mathrm{kV}, 30$ seconds, and separated at $6.0 \mathrm{kV}$ for $35 \mathrm{~min}$.

Sequencing was done by the Fluorescent dye terminator sequencing method and, prior to sequencing, PCR solutions were purified with NucleoSpin® Extract II (MachereyNagel).

\section{Specific markers design}

In order to design a second pair of PCR-specific cherimoya primers (AChF2 and AChR2; Table 2.2), trnL-F universal marker was selected to amplify and sequence 15 previously used DNA samples (Larranaga \& Hormaza 2015, chapter 1) (Table 2.1). Newly raw sequenced trnL-F fragments were aligned by MUSCLE (MEGA5 version 5.05) (Tamura et al. 2011) using the default options. Inter-species polymorphisms among $A$. cherimola and other species were manually identified while intra-specific variations were not considered. Two specific primers were designed locating the $3^{\prime}$-end of each primer targeting cherimoya specific variant sites. The expected size of the amplicon was $197 \mathrm{bp}$. An optimal annealing temperature was established by empirical means. A homology search was conducted with the BLAST tool to indicate which species could be amplified with these new primers.

\section{Application of specific primers}

Specific A. cherimola matK-based primers (AChF1 and AChR1) (Larranaga \& Hormaza 2015) were tested in 546 cherimoya accessions, 296 from the cherimoya Spanish collection and 250 collected in Central America. Germplasm accession samples with an American origin and a known geolocation (160) and all accessions from Central America (250) were mapped using ArcMap 10.1 with presence/absence of amplification. WGS84 geographical projection was settled, and a layer with country boundaries downloaded from the DIVA GIS web page 
and layer 1:10 Cross-blended Hypsometric Tints from Natural Earth was used. Specific $A$. cherimola trnL-F-based primers (AChF2 and AChR2) were tested for the same 546 cherimoya accessions.

Table 2.1. Country of origin, codes and number of accessions and plant genotypes used in this study.

\begin{tabular}{|c|c|c|c|c|c|c|}
\hline & $\begin{array}{l}\text { Country } \\
\text { of Origin }\end{array}$ & $\begin{array}{l}\text { Number of } \\
\text { accessions }\end{array}$ & & Code & Species & $\begin{array}{l}\text { Country } \\
\text { of origin }\end{array}$ \\
\hline & Australia & 13 & & Che1 & A. cherimola & Spain \\
\hline & Bolivia & 16 & & Che2 & A. cherimola & Ecuador \\
\hline & Chile & 9 & & Che3 & A. cherimola & Peru \\
\hline & Colombia & 5 & & Ret1 & A. reticulata & Honduras \\
\hline & Costa Rica & 1 & & Ret2 & A. reticulata & Honduras \\
\hline \multirow{8}{*}{$\begin{array}{l}\text { Cherimoya } \\
\text { IHSM-UMA-CSIC } \\
\text { collection } \\
\text { accessions }\end{array}$} & Ecuador & 47 & & Squ2 & A. squamosa & Unknown \\
\hline & Italy & 3 & & Squ3 & A. squamosa & Honduras \\
\hline & Japan & 1 & & Mur2 & A. muricata & Honduras \\
\hline & Mexico & 6 & & Mur3 & A. muricata & Guatemala \\
\hline & Peru & 126 & & Mac2 & A. macroprophyllata & Honduras \\
\hline & Portugal & 26 & \multirow{12}{*}{$\begin{array}{l}\text { Genotypes } \\
\text { used for } \\
\text { primers design }\end{array}$} & Mac3 & A. macroprophyllata & Guatemala \\
\hline & Spain & 7 & & Gla1 & A. glabra & Unknown \\
\hline & USA & 36 & & Gla3 & A. glabra & Unknown \\
\hline \multirow{9}{*}{$\begin{array}{l}\text { Cherimoya } \\
\text { Central America } \\
\text { samples }\end{array}$} & Guatemala & 40 & & Pur1 & A. purpurea & Honduras \\
\hline & Honduras & 137 & & Pur3 & A. purpurea & Costa Rica \\
\hline & Costa Rica & 73 & & Lie1 & A. liebmanniana & Honduras \\
\hline & & & & Lon1 & A. longiflora & Mexico \\
\hline & & & & Mon1 & A. montana & Unknown \\
\hline & & & & Sen 1 & A. senegalensis & Unknown \\
\hline & & & & Ema1 & A. emarginata & Paraguay \\
\hline & & & & Neo1 & A. neosalicifolia & Paraguay \\
\hline & & & & Tri1 & Asimina triloba & Unknown \\
\hline
\end{tabular}

\section{Sequence analysis}

Fourteen DNA samples that did not amplify and 5 that showed amplification with AChF1 and AChR1 were amplified and sequenced with universal matK primers to analyze the reason for the absence of amplification. Since these specific primers were based on a single nucleotide variant positioned on each $3^{\prime}$-end, these locations were primarily observed. Both forward and reverse primers were designed to hybridize with a $C$ and an $A$, while the rest of the sequences belonging to the other species showed a $T$ and a $C$ respectively. 
Table 2.2. Details of the primers used and designed including sequence, PCR annealing temperatures, expected PCR product size, target species and references.

\begin{tabular}{|c|c|c|c|c|c|c|}
\hline Name & Sense & Sequence $5^{\prime}-3^{\prime}$ & $\begin{array}{l}\text { Annealing } \\
\left.\text { temp. ( }{ }^{\circ} \mathrm{C}\right)\end{array}$ & $\begin{array}{l}\text { Expected } \\
\text { size }(p b)\end{array}$ & Specificity & Reference \\
\hline $\begin{array}{l}\text { AChF1 } \\
\text { AChR1 }\end{array}$ & $\mathrm{R}$ & $\begin{array}{l}\text { GTATATGAATGTGAATCGGTATTC } \\
\text { TTGACTCCTTACTGCGGAAT }\end{array}$ & 65 & 396 & $\begin{array}{l}\text { Annona } \\
\text { cherimola }\end{array}$ & $\begin{array}{l}\text { Larranaga \& } \\
\text { Hormaza, } \\
2015\end{array}$ \\
\hline $\begin{array}{l}\text { AChF2 } \\
\text { AChR2 }\end{array}$ & $\mathrm{F}$ & $\begin{array}{l}\text { ССАTTTTCCСССССТААTT } \\
\text { САATAGTGGAGATTССTTGССT }\end{array}$ & 66 & 197 & $\begin{array}{l}\text { Annona } \\
\text { cherimola }\end{array}$ & \\
\hline $\begin{array}{l}\text { 1RKim } \\
\text { 3FKim }\end{array}$ & $\mathrm{F}$ & $\begin{array}{l}\text { ACCCAGTCCATCTGGAAATCTTGGTTC } \\
\text { CGTACAGTACTTTTGTGTTTACGAG }\end{array}$ & 52 & & $\begin{array}{l}\text { Universal- } \\
\text { matK }\end{array}$ & $\begin{array}{l}\text { Kuzmina M } \\
\text { \& Ivanova } \\
\mathrm{N}, 2011\end{array}$ \\
\hline C & $\mathrm{R}$ & $\begin{array}{l}\text { CGAAATCGGTAGACGCTACG } \\
\text { ATTTGAACTGGTGACACGAG }\end{array}$ & 60 & & $\begin{array}{l}\text { Universal- } \\
\text { trnL-F }\end{array}$ & $\begin{array}{l}\text { Taberlet et } \\
\text { al. } 1991\end{array}$ \\
\hline
\end{tabular}

\section{RESULTS}

\section{Specific markers}

Fifteen DNA samples belonging to 7 different Annona species (Table 2.1) were amplified with trnL-F universal primers to design the primers AChF2 and AChR2 based on their sequences (Table 2.2). Raw sequences were aligned and two SNPs were shared by all the $A$. cherimola samples but reveal differences in the sequences of the rest of other species. These SNPs were used to locate the $3^{\prime}$-end of each new primer. Primer specificity was verified using 15 samples of different Annona species and one Asimina triloba (Figure 2.1). Just one band of the expected size (197 bp) appeared when the A. cherimola DNA was used.

Interestingly, some of the raw sequences showed an electropherogram with a mixed pattern of peaks after a certain point, which could indicate a compression in the sequencing process since it starts after several thymines or cytosines (Figure 2.2). In particular, both sequences of $A$. reticulata, $A$. squamosa and $A$. muricata showed multiple peaks after the position 285-315 (depending of each raw sequence) and 12-15 thymines. A. macrophyllata sequences showed multiple peaks after the position 582 or 583 and 11 cytosines. These results could also be due to the presence of more than one PCR product although just a single band was observed in the agarose gels.

The homology search conducted with BLAST (03-2014) showed a $100 \%$ query cover for the forward primer and identity with $t r n L-F$ sequences of $A$. cherimola, $A$. pruinosa, $A$. dumetorum and $A$. bicolor, while the reverse primer showed identity in the 3 '-end for trnL-F entries of $A$. cherimola and $A$. pruinosa only. 


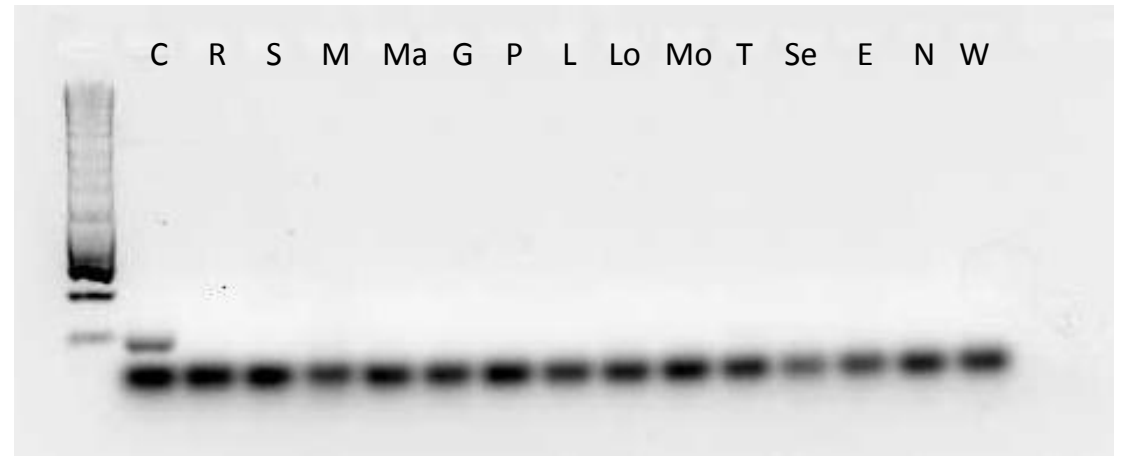

Figure 2.1. Electrophoresis in $1 \%$ agarose gels of cherimoya specific PCR reactions using the AChF2 and AChR2 primers and 14 DNA samples from different species in the Annonaceae used as templates. (C) A. cherimola; Che1, (R) A. reticulata ; Ret1, (S) A. squamosa; Squ2, (M) A. muricata; Mur2, (Ma) A. macroprophyllata; Mac2 (G) A. glabra; Gla1, (P) A. purpurea; Pur1, (L) A. liebmaniana; Lie1, (Lo) A. longiflora; Lon1, (Mo) A. montana; Mon1, (T) A. triloba; Tri1, (Se) A. senegalensis; Sen1, (E) A. emarginata; Ema1, (N) A. neosalicifolia; Neo1, (W) Water. Taxon codes are indicated in Table 2.1. Hiperladder $1 \mathrm{~Kb}$ of Bioline was used as size marker.

\section{Application of specific primers}

AChF1 and AChR1 primers were successful to amplify 291 (98.3\%) DNA samples from the cherimoya germplasm bank, while five (1.7\%) failed to amplify. These five genotypes (coded as Bolivia Seedling2, Bolivia Seedling3, Bonita, Booth and Lucida) came from a collection in California, USA, with Mexican, Bolivian or unknown origin. In addition, $66 \%$ of the samples samples classified as A. cherimola from Guatemala (35/40), Honduras (60/137) and Costa Rica (70/73), amplified with the primers AChF1 and AChR1. American accessions from the Spanish collection with well-known geographic coordinates, and all Central American samples were mapped in Figure 2.3, indicating whether each sample showed amplification or not.

Primers AChF2 and AChR2 amplified all accessions (546) but four (0.73\%) of the analyzed samples. Two of them belong to the germplasm field collection and their origin is the island of Madeira, Portugal, and two were collected in Guatemala. These last two accessions also failed to amplify with the first set of primers AChF1/AChR1 


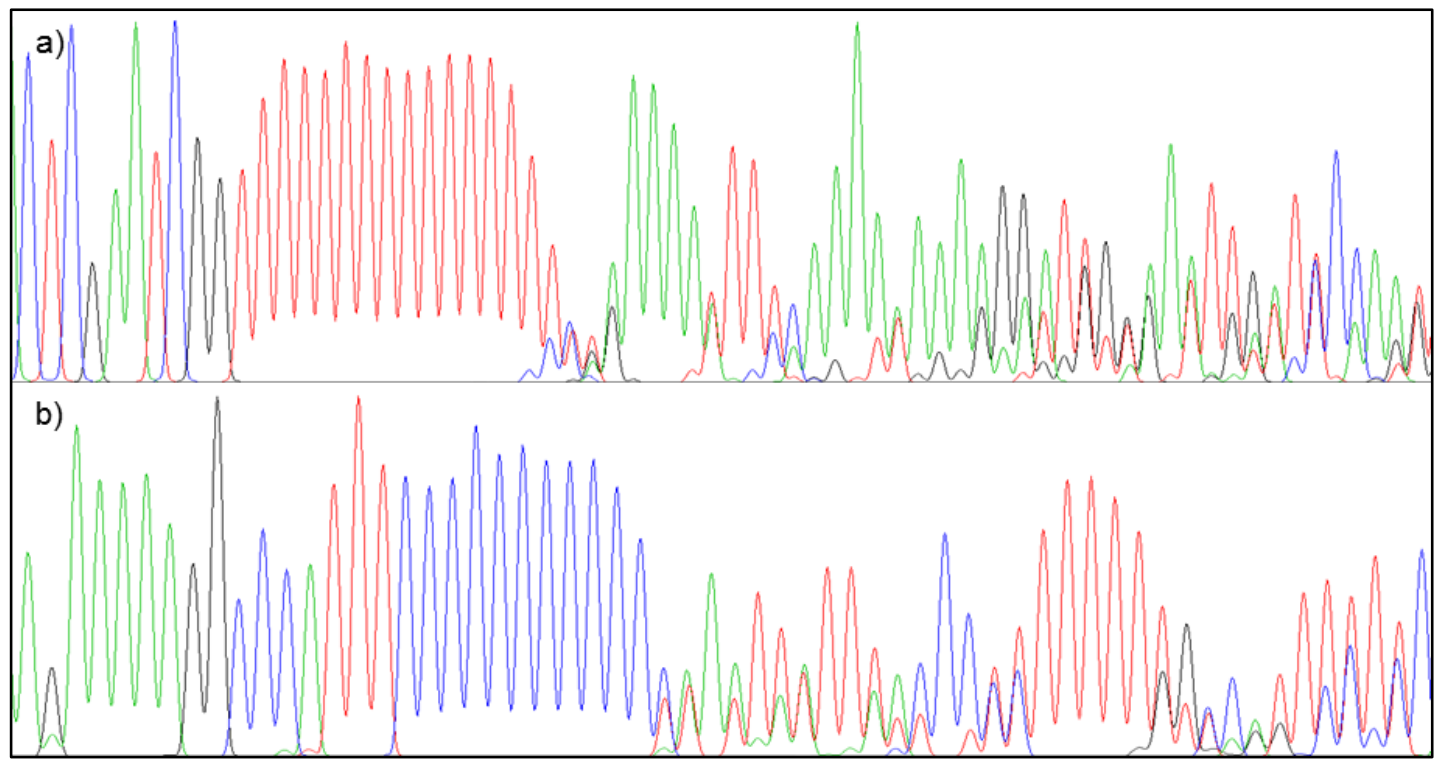

Figure 2.2. Electropherogram of the mix pattern peaks for the sample Squ2 in the position 315 and Mac2 in the position 585 visualized with Chromas Lite version 2.1 (2012). Thymines are represented in red, adenines in green, citosines in blue and guanines in black.

\section{Sequence analysis}

Fourteen samples (five from the IHSM-UMA-CSIC collection, and nine from Honduras and Guatemala) with no amplification using the primes AChR1/AChF1 were amplified with matK universal markers and sequenced. Sequencing results were aligned and the positions used to design AChF1 and AChR1 were analyzed manually. All of them did not share any of the two variants but a $T$ and a $C$ instead, like the rest of the species used in the previous alignment (Larranaga \& Hormaza 2015, chapter 1). In addition, five samples from Honduras and Guatemala that showed an amplicon with the set of primers AChF1/AChR1 were also amplified and sequenced with matK universal primers and analyzed in the same positions: all of them showed a $\mathrm{C}$ and an $\mathrm{A}$ respectively. 


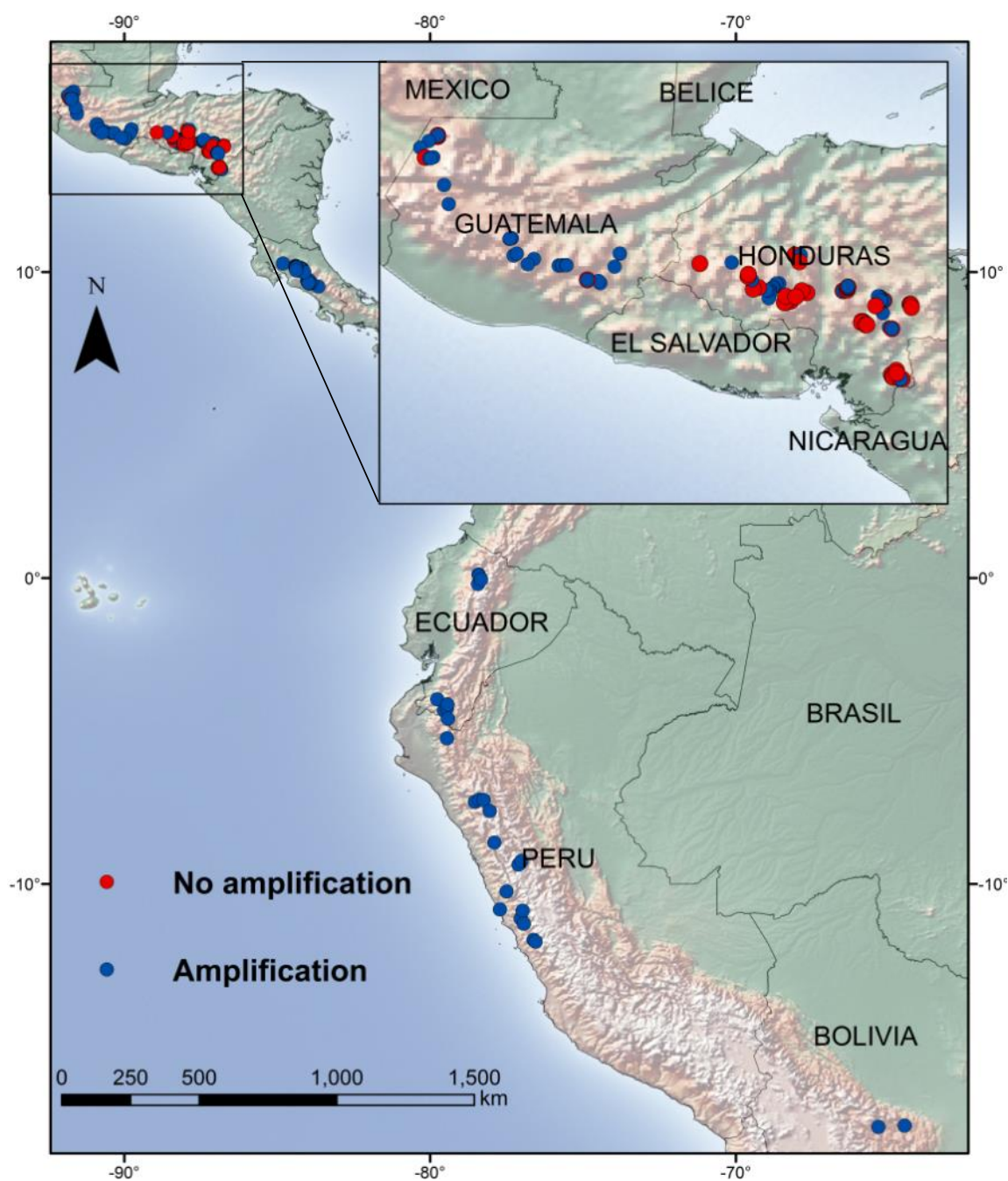

Figure 2.3. Geolocation of 411 samples amplified with $A C h F 1$ and AChR1 through PCR. Blue color blue indicates the apparition of an amplicon and red, no amplification

\section{DISCUSSION}

Both morphological and molecular characters are used in the identification and classification of species. However, the development of new techniques to produce large amounts of molecular data is revolutionizing many areas of the biological sciences including taxonomy. DNA barcoding would permit to identify and discover new species just amplifying the query DNA with the established barcode genes, sequencing the amplicon and comparing the result with highly robust databases.

In 2015 a DNA barcoding study was conducted among species of the genus Annona with significant agronomic interest and some other species included in databases using the proposed matK and rbcL genes for the barcode of life in plants (Larranaga \& Hormaza 2015, chapter 1 ). Only matk could discriminate among all of them. In addition, specific primers 
based on this locus were designed in order to have an even easier tool to recognize these species by a simple PCR and visualization of a band in an agarose electrophoresis gel. The presence of a band would indicate that the DNA template belongs to the species it was designed for or to another species that was not included in the alignment and that could share the same primers targets. When a genetic variant appears amongst a species its distribution will depend on the reproductive success of the individuals carrying it, migration, and genetic drift (Pereira et al. 2008b).

Primers AChF1 and AChR1 were designed using three cherimoya individuals from three very distant regions (in order to recover as much intraspecific variability as possible): Spain, Honduras and Peru. The amplification of 296 accessions of the Annona cherimola world reference collection in Spain with those primers showed that just a few samples $(n=5)$ did not show an amplification band. These samples were obtained from a USA collection with North and South American origin. In addition, 85/250 DNA samples collected in Central America did also show absence of amplification. A total of 411 samples were mapped geographically and the results revealed that the samples that did not amplify were mainly obtained in Honduras (56.2\%), followed by Guatemala (12,5\%) and Costa Rica (4.1\%). This could indicate a spatial correlation among the presence/absence of the PCR product. The two Californian accessions with a Bolivian origin that did not amplify could be an indicator of a very direct exchange between Central America and this South American country although the possibility of an error in the passport information cannot be excluded.

In order to assess if the non-amplifying samples had missing one or both SNPs, several samples were amplified with the matK universal primers and their sequences showed just two haplotypes: genotypes with the two variants (showing amplification) or genotypes without them (showing absence of amplification). If such pattern is true, the haplotype 1 is present all over the cherimoya distribution area, while haplotype 2 is characteristic of Central America, mainly Honduras. These results would support the hypothesis of a Mesoamerican origin of the species (Larranaga et al. under revision, chapter 4 , chapter 5 ). In addition, the presence of two genotypes could also indicate a hybrid origin of the species in which each chloroplast haplotype could derive from different species. Further research could provide additional information on this hypothesis.

With the aim of finding a global specific marker for $A$. cherimola, the trnL-F locus from several species was sequenced, and two shared SNPs among $A$. cherimola accessions were used to design a species-specific set of primers. 546 DNA samples were analyzed with a successful global amplification. Remarkably, several genotypes showed several peaks after a certain point (after a group of approximately 10 thymines or cytosines) and although this could be due to sequencing problems we cannot discard having more than one PCR product 
with similar electrophoresis mobility. Pierie et al. (2007) reported an ancient paralogy in the cpDNA trnL-F region in Annonaceae and, although additional studies would be needed, the observations made could be the result of the amplification of two copies. The homology search conducted with the BLAST tool indicate that AChF2 and AChR2 could also amplify A. pruinosa. Again, since not all species of Annona have been sampled here and their $t r n \mathrm{~L}-\mathrm{F}$ sequences has not been uploaded to GenBank, these new primers could also amplify other taxonomically close species. In any case, the results obtained provide one marker (AChF1/AChR1) that seems to be not present in some cherimoya individuals from Central America, and another marker (AchF2/AChR2) present in all the cherimoya samples analyzed. Both markers could be useful to discriminate this species from other taxonomically related Annona species. 


$$
\infty
$$




\title{
PHYLOGENETIC STUDY OF THE ATTA SECTION AND CLOSELY RELATED SPECIES IN THE GENUS ANNONA, ANNONACEAE
}

\begin{abstract}
Cherimoya (Annona cherimola Mill.) belongs to the Atta section of the genus Annona, which is the type genus of the pantropical basal angiosperm family Annonaceae. However, while most of the species in the Atta section are known to be native to Central America and the Caribbean, the origin of the cherimoya is still under discussion. In this paper, a phylogenetic study of this species and some of its taxonomically closest species in the Annonaceae is carried out using five fragments of different coding and non-coding chloroplast regions. Results did not show monophyly of the Atta section. Nevertheless, a common ancestor was shared among species belonging to Atta and neighboring sections. A. cherimola samples from 10 different countries showed a modest structure having at the base of the clade some of the Mesoamerican samples. In addition, this species seems to be especially close to $A$. pruinosa. Neighbour joining trees using the model kimura 2 parameters, maximum likelihood and bayesian trees were constructed for the alignment of each five loci and all possible concatenations.
\end{abstract}

\section{INTRODUCTION}

The Annonnaceae is the largest family in the early-divergent Magnoliid clade of angiosperms with approximately 108 genera and 2400 species (Chatrou et al. 2012). It shows a pantropical distribution and is about 82-98 Myr old (Richardson et al. 2004; Scharaschkin \& Doyle 2005; Su \& Saunders 2009). A limited number of species, belonging to just two genera [Annona and Asimina, since Rollinia has recently been included in the Annona genus (Rainer 2007)], produce edible fruits. Most of them are included in the genus Annona [Annona cherimola (cherimoya), A. squamosa (sugar apple), A. muricata (soursop), the hybrid among $A$. cherimola and $A$. squamosa (atemoya), $A$. reticulata (custard apple), $A$. diversifolia (ilama), $A$. glabra (pond apple), A. purpurea (soncoya) and one in Asimina [Asimina triloba (pawpaw)], the only species in the family adapted to temperate climates. Different palynological, morphological (Doyle \& Le Thomas, 1994; 1996), and molecular phylogenetic studies have been conducted in this family. The latter includes mainly chloroplast sequences: $r b c L$, matK, $n d h \mathrm{~F}, t r n \mathrm{~L}, t r n \mathrm{~T}-\mathrm{L}, t r n \mathrm{~L}-\mathrm{F}, t r n S-\mathrm{G}$, atpB-rbcL, trnH-psbA, $y c f 1, r p / 32-t r n \mathrm{~L}$, or $n d h \mathrm{~F}-r p / 32$ (Chatrou et al. 2012, Richardson et al. 2004, Mols et al. 2004, Pirie et al. 2005, Erkens et al. 2012, Thomas et al. 2012b, Chaowasku et al. 2014). 
The Annona genus described by Safford (1914), which includes about 162 species (Chatrou et al. 2012) and is distributed mainly in tropical America with a few species native to Africa, was first named by Linnaeus (Linnaeus 1737) and it could have emerged during the Miocene (Richardsson et al. 2004; Su \& Saunders 2009). In addition to chloroplast DNA analyses, additional molecular studies have been carried out in Annona mainly for fingerprinting and genetic diversity studies; those include isozymes (Ellstrand \& Lee 1987; Pascual et al. 1993; Perfectti \& Pascual 1998a, 2004, 2005), randomly amplified polymorphic DNA (RAPDs) (Ronning et al. 1995), amplified fragment length polymorphism (AFLPs) (Rahman et al. 1998) and, more recently, microsatellites (Escribano et al. 2004, 2007, 2008a, 2008b; Pereira et al. 2008a; van Zonneveld et al. 2012) but also microsatellite flanking regions for phylogenetic analyses (Chatrou et al. 2009). Safford (1914) divided this genus in 5 groups and 14 section whereas Fries (1959) reorganized it into 17 sections. The last included 12 species in the Atta section: Annona acutifolia Saff. Ex R.E.FR., A. cherimola Mill., A. cubensis R. E. Fr., A. frutescens R. E. Fr., A. longiflora S. Wats., A. micrantha Bertero ex Spreng, A. palmeri Saff., A. praetermisa Fawc. \& Rendle, A. primigenia Standl. \& Steyerm., A. reticulata L., A. squamosa L. and $A$. urbaniana R. E. Fr. A. acutifolia and $A$. micrantha are currently considered as a synonymous of $A$. cherimola and $A$. reticulata respectively (Rainer \& Chatrou 2016). Annona pruinosa, described more recently (Schatz 1992), has also been included in this section. According to the dichotomous key of Fries (1959) sections Pillanona, Chelenocarpus and Ilama would be the closest to Atta. Most of these species are native to Central America and Caribbean countries although they have been naturalized and cultivated in other parts of the world.

The main aim of this phylogenetic study, based on chloroplast sequences, was to analyze the monophyly of the Atta section, with a special focus on A. cherimola. A. cherimola is a semi domesticated fruit tree species distributed mainly in tropical and subtropical America in altitudes above 900-1000 masl, where the commercial and agronomic management of cherimoya is limited. However, it is also cultivated in some countries with temperate climates like USA, Spain or Australia. The fruit is normally consumed fresh although it is also being used for the production of ice-creams, shakes or yogurts. The center of origin of the species has been generally set in South America, specifically in the interandean valleys of Northern Peru and Southern Ecuador. However, a recent study has demonstrated that higher molecular diversity values based on microsatellites markers are obtained in Mesoamerica (Larranaga et al. under revision, chapter 4). This fact could be pointing to this area as the center of origin of the species, which has also been defended by other authors (Pozorski \& Pozorski 1997). 
In order to have a clearer picture of the phylogenetic relationships between cherimoya and genetically close species in the Annonaceae, we studied in detail five fragments of different coding and non-coding chloroplast regions. Two phylogenetic approaches were applied: maximum likelihood and bayesian analysis. In addition, neighbor joining trees with kimura 2 parameters model were also constructed for the same set of data.

\section{MATERIALS AND METHODS}

\section{Taxon Sampling}

Leaves from 46 Annona trees belonging to 17 species [Annona cherimola Mill. (13 samples), A. conica (Ruiz \& Pav. ex G. Don) Westra (1 sample), A. emarginata (Schltdl.) H. Rainer (3 samples), A. glabra L. (2 samples), A. liebmanniana Baill. (2 samples), A. longiflora S. Watson (2 samples), A. macroprophyllata Donn. Sm. (2 samples), A. montana Macfad. (2 samples), A. muricata L. (2 samples), A. neosalicifolia H. Rainer (3 samples), A. pittieri Donn. Sm. (3 samples), A. pruinosa G. E. Schatz (2 samples), A. purpurea Moc. \&Sessé ex Dunal (2 samples), A. rensoniana (Standl.) H. Rainer (2 samples), A. reticulata L. (2 samples), A. senegalensis Pers. (1 sample), A. squamosa L. (2 samples)] were collected. Five of those species ( $A$. cherimola, A. longiflora, A. pruinosa, A. reticulata and $A$. squamosa) are included in the Atta section (Fries 1959) of the Annona genus. The materials were either collected from the wild or from an ex situ Annona germplasm collection maintained at the IHSM-UMA-CSIC in Málaga (Spain), at latitude $36^{\circ} 45^{\prime} \mathrm{N}$, longitude $4^{\circ} 4^{\prime} \mathrm{W}$ and altitude 35 masl. Their geographic origin and codes are described in Table 3.1. All trees sampled were previously identified using morphological characters. As outgroups GenBank sequences of Annickia pilosa (Annonaceae) were downloaded and its codes are also indicated in Table 3.1.

\section{DNA extraction, amplification and sequencing}

Plant DNA extraction was performed from $50 \mathrm{mg}$ of young leaf tissues by a modified CTAB method (Viruel \& Hormaza 2004). Each PCR reaction, carried out in an I-cycler (Bio-Rad Laboratories, Hercules, CA, USA) thermocycler, contained $16 \mathrm{mM}\left(\mathrm{NH}_{4}\right)_{2} \mathrm{SO}_{4}, 67 \mathrm{mM}$ Tris$\mathrm{ClH} \mathrm{pH} \mathrm{8.8,0.01 \%} \mathrm{Tween-20,} 3 \mathrm{mM} \mathrm{MgCl}$, $0.1 \mathrm{mM}$ each dNTP, $0.3 \mu \mathrm{M}$ each primer, $20 \mathrm{ng}$ genomic DNA and 1 unit of BioTaq ${ }^{\mathrm{TM}}$ DNA polymerase (Bioline, London, UK) in a final volume of $30 \mu \mathrm{l}$. Universal primers used to amplify $r b c L$ were rbcLaF and rbcLaR, for matK MatK_1RKim-f and MatK_3FKim-r and for trnH-psbA psbA3-f and trnHf_05 (Kuzmina \& Ivanova 2011). For $r b c L$ the temperature profile was: an initial step of $4 \mathrm{~min}$ at $95^{\circ} \mathrm{C}, 5$ cycles of $30 \mathrm{~s}$ at $94^{\circ} \mathrm{C}, 1 \mathrm{~min}$ at $55^{\circ} \mathrm{C}$ and $1 \mathrm{~min}$ at $72^{\circ} \mathrm{C}, 30$ cycles of $30 \mathrm{~s}$ at $94^{\circ} \mathrm{C}, 1 \mathrm{~min}$ at $54^{\circ} \mathrm{C}$ and $1 \mathrm{~min}$ at $72^{\circ} \mathrm{C}$ and a final step of $10 \mathrm{~min}$ at $72^{\circ} \mathrm{C}$. For matK the temperature profile was: 
an initial step of $1 \mathrm{~min}$ at $94^{\circ} \mathrm{C}, 35$ cycles of $30 \mathrm{~s}$ at $94^{\circ} \mathrm{C}, 20 \mathrm{~s}$ at $52^{\circ} \mathrm{C}$ and $50 \mathrm{~s}$ at $72^{\circ} \mathrm{C}$ and a final step of $5 \mathrm{~min}$ at $72^{\circ} \mathrm{C}$. For $t r n \mathrm{H}-p s b \mathrm{~A}$ the temperature profile was: an initial step of $4 \mathrm{~min}$ at $95^{\circ} \mathrm{C}, 35$ cycles of $30 \mathrm{~s}$ at $94^{\circ} \mathrm{C}, 1 \mathrm{~min}$ at $55^{\circ} \mathrm{C}$ and $1 \mathrm{~min}$ at $72^{\circ} \mathrm{C}$, and a final step of $10 \mathrm{~min}$ at $72^{\circ} \mathrm{C}$. For intron $t r h \mathrm{~L}$ and $n d h \mathrm{~F}$, the universal primers $\mathrm{c}$ and $\mathrm{d}$ published in Taberlet et al. (1991) and 972 and 2110 published in Olmstead and Sweere (1994) were used, respectively, with the following temperature profile: an initial step of $1 \mathrm{~min}$ at $94^{\circ} \mathrm{C}, 35$ cycles of $30 \mathrm{~s}$ at $94^{\circ} \mathrm{C}, 30 \mathrm{~s}$ at $55^{\circ} \mathrm{C}$ and $1 \mathrm{~min}$ at $72^{\circ} \mathrm{C}$, and a final step of $5 \mathrm{~min}$ at $72^{\circ} \mathrm{C}$. Prior to sequencing, $3 \mu \mathrm{l}$ PCR solutions were visualized in $1 \%$ agarose gels stained with Gel Red (1X) and the rest purified with NucleoSpin® Extract II (Macherey-Nagel). Sequencing was done by the fluorescent dye terminator sequencing method (Macrogen). New DNA sequences generated for this study were uploaded to GenBank and their accession numbers indicated in Table 3.1.

Table 3.1. Information of the plant material used.

\begin{tabular}{|c|c|c|c|c|c|c|c|c|}
\hline Species & $\begin{array}{l}\text { Country of } \\
\text { origin }\end{array}$ & Code & $\begin{array}{l}\text { Section } \\
\text { (Fries 1959) }\end{array}$ & $\begin{array}{l}\text { matk } \\
\text { (genbank) }\end{array}$ & $\begin{array}{l}\text { rbcL } \\
\text { (genbank) }\end{array}$ & $\begin{array}{l}\text { ndhF } \\
\text { (genbank) }\end{array}$ & $\begin{array}{l}\text { intronL } \\
\text { (genbank) }\end{array}$ & $\begin{array}{l}\text { trnH-psbA } \\
\text { (genbank) }\end{array}$ \\
\hline \multirow{13}{*}{$\begin{array}{l}\text { A. cherimola } \\
\text { Mill. }\end{array}$} & Mexico (BC) & Ache1_mex & \multirow{13}{*}{ Atta } & KX663840 & KX663878 & KX663916 & KX663962 & KX664007 \\
\hline & Honduras (BC) & Ache2_hon & & KX663841 & KX663879 & KX663917 & KX663963 & KX664008 \\
\hline & Honduras (W) & Ache3_hon & & KX663842 & KX663880 & KX663918 & KX663964 & KX664009 \\
\hline & Guatemala (W) & Ache4_gua & & KX663843 & KX663881 & KX663919 & KX663965 & KX664010 \\
\hline & Costa Rica (W) & Ache5_cr & & KX663844 & KX663882 & KX663920 & KX663966 & KX664011 \\
\hline & Colombia (BC) & Ache6_col & & KX663845 & KX663883 & KX663921 & KX663967 & KX664012 \\
\hline & $\begin{array}{l}\text { Ecuador-Norte } \\
\text { (BC) }\end{array}$ & Ache7_ecu & & KX663846 & KX663884 & KX663922 & KX663968 & KX664013 \\
\hline & $\begin{array}{l}\text { Ecuador-Sur } \\
\text { (BC) }\end{array}$ & Ache8_ecu & & KX663847 & KX663885 & KX663923 & KX663969 & KX664014 \\
\hline & $\begin{array}{l}\text { Peru-Norte } \\
\text { (BC) }\end{array}$ & Ache9_per & & KX663848 & KX663886 & KX663924 & KX663970 & KX664015 \\
\hline & Peru-Sur (BC) & Ache10_per & & KX663849 & KX663887 & KX663925 & KX663971 & KX664016 \\
\hline & Bolivia (BC) & Ache11_per & & KX663850 & KX663888 & KX663926 & KX663972 & KX664017 \\
\hline & Madeira $(B C)$ & Ache12_mad & & KX663851 & KX663889 & KX663927 & KX663973 & - \\
\hline & España (BC) & Ache13_spa & & KM068846 & KM068867 & KX663928 & KX663974 & KX664018 \\
\hline \multirow{2}{*}{ A. reticulata $\mathrm{L}$. } & Honduras (W) & Aret1_hon & \multirow{2}{*}{ Atta } & KM068850 & KM068871 & KX663929 & KX663975 & KX664019 \\
\hline & Costa Rica (W) & Aret2_cr & & KX663852 & KX663890 & KX663930 & KX663976 & KX664020 \\
\hline \multirow{2}{*}{ A. squamosa $\mathrm{L}$. } & Unknown (BC) & Asqu1 & \multirow{2}{*}{ Atta } & KM068853 & KM068874 & KX663931 & KX663977 & KX664021 \\
\hline & Honduras (BC) & Asqu2_hon & & KM068854 & KM068875 & KX663932 & KX663978 & KX664022 \\
\hline \multirow{2}{*}{$\begin{array}{l}\text { A. } \\
\text { macrophrophylla } \\
\text { ta Donn. Sm. }\end{array}$} & Honduras (BC) & Amac1_hon & \multirow[t]{2}{*}{ Ilama } & KX663853 & KX663891 & KX663933 & KX663979 & KX664023 \\
\hline & Guatemala (W) & Amac2_gua & & KM068860 & KM068881 & KX663934 & KX663980 & KX664024 \\
\hline \multirow[t]{2}{*}{$\begin{array}{l}\text { A. liebmaniana } \\
\text { Baill. }\end{array}$} & Honduras (W) & Alie1_hon & \multirow[t]{2}{*}{ Chalenocarpus } & KX663854 & KX663892 & KX663935 & KX663981 & KX664025 \\
\hline & Honduras (W) & Alie2_hon & & KX663855 & KX663893 & KX663936 & KX663982 & KX664026 \\
\hline \multirow{2}{*}{$\begin{array}{l}\text { A. longiflora S. } \\
\text { Watson }\end{array}$} & Mexico $(W)$ & Alon1_mex & \multirow[t]{2}{*}{ Atta } & KX663856 & KX663894 & KX663937 & KX663983 & KX664027 \\
\hline & Mexico (W) & Alon2_mex & & KX663857 & KX663895 & KX663938 & KX663984 & KX664028 \\
\hline
\end{tabular}




\begin{tabular}{|c|c|c|c|c|c|c|c|c|}
\hline \multirow{3}{*}{$\begin{array}{l}\text { A. pittieri Donn. } \\
\text { Sm. }\end{array}$} & Costa Rica (W) & Apit1_cr & \multirow[b]{2}{*}{ Chalenocarpus } & KX663858 & KX663896 & KX663939 & KX663985 & KX664029 \\
\hline & Costa Rica (W) & Apit2_cr & & KX663859 & KX663897 & KX663940 & KX663986 & $<200 p b$ \\
\hline & Costa Rica (W) & Apit3_cr & & KX663860 & KX663898 & KX663941 & KX663987 & $<200 \mathrm{pb}$ \\
\hline \multirow{2}{*}{$\begin{array}{l}\text { A. pruinosa G. } \\
\text { E. Schatz }\end{array}$} & Costa Rica (W) & Apru2_cr & \multirow[t]{2}{*}{ Atta } & KX663861 & KX663899 & KX663942 & KX663988 & KX664030 \\
\hline & Costa Rica (W) & Apru3_cr & & KX663862 & KX663900 & KX663943 & KX663989 & KX664031 \\
\hline \multirow{2}{*}{$\begin{array}{l}\text { A. purpurea } \\
\text { Moc. \& Sessé ex } \\
\text { Dunal }\end{array}$} & Honduras (W) & Apur1_hon & \multirow[t]{2}{*}{ Uloterpus } & KM068864 & KM068885 & KX663944 & KX663990 & KX664032 \\
\hline & Costa Rica (W) & Apur2_cr & & KM068866 & KM068887 & KX663945 & KX663991 & KX664033 \\
\hline \multirow{2}{*}{ A. muricata L. } & Ecuador (BC) & Amur1_ecu & \multirow{2}{*}{ Annona } & KX663863 & KX663901 & KX663946 & - & KX664034 \\
\hline & Honduras (W) & Amur2_hon & & KX663864 & KX663902 & KX663947 & KX663992 & KX664035 \\
\hline \multirow{2}{*}{$\begin{array}{l}\text { A. rensoniana } \\
\text { (Standl.) H. } \\
\text { Rainer }\end{array}$} & Honduras (W) & Aren1_hon & \multirow{2}{*}{$\begin{array}{l}\text { Former Rollinia } \\
\text { (Rainer 2007) }\end{array}$} & KX663865 & KX663903 & KX663948 & KX663993 & KX664036 \\
\hline & Honduras (W) & Aren2_hon & & KX663866 & KX663904 & KX663949 & KX663994 & KX664037 \\
\hline \multirow[t]{2}{*}{$\begin{array}{l}\text { A. montana } \\
\text { Mcfad. }\end{array}$} & Unkown (BC) & Amon1 & \multirow[t]{2}{*}{ Annona } & KX663867 & KX663905 & KX663950 & KX663995 & KX664038 \\
\hline & Unkown (BC) & Amon2 & & KX663868 & KX663906 & KX663951 & KX663996 & KX664039 \\
\hline \multirow{2}{*}{ A. glabra L. } & Unkown (BC) & Agla1 & \multirow{2}{*}{ Phelloxylon } & KX663869 & KX663907 & KX663952 & KX663997 & KX664040 \\
\hline & Honduras (W) & Agla2_hon & & KM068862 & KM068883 & KX663953 & KX663998 & KX664041 \\
\hline $\begin{array}{l}\text { A. senegalensis } \\
\text { Pers. }\end{array}$ & Unknown (BC) & Asen1 & Helogenia & KX663870 & KX663908 & KX663954 & KX663999 & $<200 \mathrm{pb}$ \\
\hline $\begin{array}{l}\text { A. conica (Ruiz } \\
\text { \& Pav. ex G. } \\
\text { Don) Westra }\end{array}$ & Unknown (BC) & Acon1 & $\begin{array}{l}\text { Former } \\
\text { Raimondia } \\
\text { (Rainer \& } \\
\text { Chatrou 2016) }\end{array}$ & KX663871 & KX663909 & KX663955 & KX664000 & KX664042 \\
\hline \multirow{3}{*}{$\begin{array}{l}\text { A. neosalicifolia } \\
\text { H. Rainer }\end{array}$} & Paraguay (BC) & Aneo1_par & \multirow{3}{*}{$\begin{array}{l}\text { Former Rollinia } \\
\text { (Rainer 2007) }\end{array}$} & KX663872 & KX663910 & KX663956 & KX664001 & KX664043 \\
\hline & Paraguay (BC) & Aneo2_par & & KX663873 & KX663911 & KX663957 & KX664002 & KX664044 \\
\hline & Paraguay (BC) & Aneo3_par & & KX663874 & KX663912 & KX663958 & KX664003 & KX664045 \\
\hline \multirow{3}{*}{$\begin{array}{l}\text { A emarginata } \\
\text { (Schltdl.) } \mathrm{H} \text {. } \\
\text { Rainer }\end{array}$} & Paraguay (BC) & Aema1_par & \multirow{3}{*}{$\begin{array}{l}\text { Former Rollinia } \\
\text { (Rainer 2007) }\end{array}$} & KX663875 & KX663913 & KX663959 & KX664004 & KX664046 \\
\hline & Paraguay (BC) & Aema2_par & & KX663876 & KX663914 & KX663960 & KX664005 & KX664047 \\
\hline & Paraguay (BC) & Aema3_par & & KX663877 & KX663915 & KX663961 & KX664006 & KX664048 \\
\hline \multicolumn{4}{|l|}{$\begin{array}{l}\text { A. pilosa (Exell) } \\
\text { Setten \& Maas }\end{array}$} & AY743488 & AY743450 & AY841402 & AY743469 & AY841444 \\
\hline
\end{tabular}

Table 3.2. DNA chloroplast genes final alignments (not including the outgroup).

\begin{tabular}{llllll}
\hline $\begin{array}{l}\text { number of } \\
\text { individuals }\end{array}$ & $\begin{array}{l}\text { coding } \\
\text { region }\end{array}$ & $\begin{array}{l}\text { number of } \\
\text { characters }\end{array}$ & $\begin{array}{l}\text { number of } \\
\text { variable } \\
\text { characters }\end{array}$ & $\begin{array}{l}\text { percentage } \\
\text { of variable } \\
\text { characters }\end{array}$ & $\begin{array}{l}\text { Model of } \\
\text { substitution } \\
\text { (jModelTest) }\end{array}$ \\
\hline 46 & yes & 813 & 91 & 11.2 & $\mathrm{HKY}+\mathrm{G}$ \\
46 & yes & 522 & 33 & 6.32 & $\mathrm{SYM}+\mathrm{I}$ \\
46 & yes & 445 & 93 & 20.9 & $\mathrm{GTR}+\mathrm{G}$ \\
45 & no & 268 & 48 & 17.91 & $\mathrm{GTR}+\mathrm{G}$ \\
45 & no & 233 & 57 & 24.46 & $\mathrm{HKY}+\mathrm{G}$ \\
\hline
\end{tabular}




\section{Phylogenetic Analysis}

MAFFT (Multiple Alignment using Fast Fourier Transform) (Katoh et al. 2002) was used for performing multiple alignments. Subsequence manual refinements and concatenation of genes were carried out with the Mesquite 3.01 program (Maddison \& Maddison 2014). All possible concatenations were constructed and the last alignment performed with MAFFT. Neighbor joining clustering algorithm using Kimura's 2 parameters model with 1000 bootstrap replications was performed using Mega 6 (Tamura et al. 2013). The Maximum likelihood (ML) algorithm implemented in RAXML-HPC2 on XSEDE web-server program available at the CIPRES portal in San Diego, CA, USA (http://www.phylo.org/sub_sections/portal/) was utilized (Miller et al. 2010) with all combination matrices. A bootstrap of 1000 replicates was performed, and the rest of the default parameters established. The jModeltest software was run with each gene alignment to select the best substitution model (Darriba et al. 2012; Guindon \& Gascuel 2003) for each case. This program was run with 3 substitution schemes. The Akaike information criterion (AIC) (Akaike 1974) was utilized to choose among models. Bayesian analyses applied to the concatenated matrices were also conducted. The alignments were partitioned, matching each partition to each gene when needed, and different substitution models applied to them. Partitions 1 (matK), and 5 (trnH-psbA) were run with the model $\mathrm{HKY}+\mathrm{G}$, partition $2(r b c \mathrm{~L})$ was run with $\mathrm{SYM}+\mathrm{I}$ and partition $3(n d h \mathrm{~F})$ and 4 (intronL) with GTR+G. Markov chain Monte Carlo (MCMC) runs were extended for 5 million generations, a burning fraction of 0.25 , with trees sampled every 1000 generations. Resulting trees (bipartitions. and con.tree files in $\mathrm{ML}$ and BA respectively) with their bootstrap/posterior probability values were plotted with FigTree (http://tree.bio.ed.ac.uk/software/figtree/).

\section{RESULTS}

The properties of each of the five DNA chloroplast regions final alignments (not including the outgroup) are shown in Table 3.2. The percentage of variation among the different regions was quite different. Within the coding regions, $r b c L$ shows the lowest variation whereas $n d h F$ shows the highest, even higher than the intron trnL. Overall, $t r n \mathrm{H}-p s b \mathrm{~A}$ showed the highest level of variation.

A total of 30 alignments ( 5 of each loci and 25 of concatenations of 2, 3, 4 or 5 genes) were assembled and three different trees constructed with neighbor joining ( $\mathrm{NJ}$ ), maximum likelihood (ML) and bayesian analysis (BA). Table 3.3 summarizes the number of nodes with a bootstrap or posterior probability $\geq 80 \%(0.8)$ and the number of monophyletic clades at the level of species applying the criteria of reciprocal monophyly (Nicolas et al. 2012). With concatenation number 15 it was not possible to construct a proper NJ tree since two different sequences were missing and complete deletion removes all sites containing a gap on any 
part of the alignment. In general terms, more robust trees were provided by the BA analysis followed by the $\mathrm{ML}$ and, finally, $\mathrm{NJ}$ distance trees.

Table 3.3. Number of nodes with a bootstrap or posterior probability $\geq 80 \%(0.8)$ and the number of monophyletic clades at the level of species applying the criteria of reciprocal monophyly.

\begin{tabular}{|c|c|c|c|c|c|c|c|}
\hline & & NJ-K2P & & Maximu & m likelihood & Bayesia & n analysis \\
\hline & & $\begin{array}{l}\text { Number of } \\
\text { clades } \\
\text { bootstrap } \\
\geq 80 \%\end{array}$ & $\begin{array}{l}\text { Monophyletic } \\
\text { clades } \\
\text { (species) }\end{array}$ & $\begin{array}{l}\text { Number } \\
\text { of clades } \\
\text { bootstra } \\
p \geq 80 \%\end{array}$ & $\begin{array}{l}\text { Monophyletic } \\
\text { clades } \\
\text { (species) }\end{array}$ & $\begin{array}{l}\text { Number } \\
\text { of clades } \\
\text { prob. } \\
80 \%\end{array}$ & $\begin{array}{l}\text { Monophyletic } \\
\text { clades } \\
\text { (species) }\end{array}$ \\
\hline 1 & matk & $\overline{6}$ & 13 & 15 & 12 & 18 & 14 \\
\hline 2 & $r b c L$ & 0 & 5 & 8 & 7 & 12 & 8 \\
\hline 3 & $n d h F$ & 1 & 10 & 17 & 13 & 19 & 13 \\
\hline 4 & intronL & 3 & 9 & 4 & 7 & 8 & 6 \\
\hline 5 & $\operatorname{trnH}-p s b \mathrm{~A}$ & 0 & 2 & 4 & 6 & 8 & 7 \\
\hline 6 & matK $+r b c L$ & 10 & 13 & 17 & 12 & 22 & 13 \\
\hline 7 & matK $+n d h F$ & 10 & 15 & 22 & 15 & 27 & 15 \\
\hline 8 & matK+intronL & 8 & 13 & 14 & 13 & 21 & 13 \\
\hline 9 & matK + trnH & 8 & 13 & 19 & 12 & 23 & 12 \\
\hline 10 & $r b c L+n d h F$ & 5 & 13 & 18 & 13 & 20 & 13 \\
\hline 11 & $r b c \mathrm{~L}+$ intron $\mathrm{L}$ & 0 & 6 & 10 & 12 & 18 & 12 \\
\hline 12 & $r b c \mathrm{~L}+t r n \mathrm{H}$ & 0 & 5 & 11 & 9 & 13 & 9 \\
\hline 13 & $n d h F+i n t r o n L$ & 1 & 10 & 18 & 15 & 18 & 14 \\
\hline 14 & $n d h \mathrm{~F}+t r n \mathrm{H}$ & 1 & 10 & 18 & 15 & 16 & 13 \\
\hline 15 & intronL+trnH & - & - & 10 & 11 & 14 & 10 \\
\hline 16 & $m a t K+r b c \mathrm{~L}+n d h \mathrm{~F}$ & 12 & 15 & 26 & 15 & 31 & 15 \\
\hline 17 & matK $+r b c \mathrm{~L}+$ intron $\mathrm{L}$ & 10 & 13 & 19 & 13 & 22 & 14 \\
\hline 18 & matK $+r b c \mathrm{~L}+t r n \mathrm{H}$ & 10 & 13 & 19 & 12 & 26 & 12 \\
\hline 19 & matK $+n d h F+i n t r o n L$ & 10 & 15 & 22 & 15 & 28 & 15 \\
\hline 20 & $m a t K+n d h \mathrm{~F}+t r n \mathrm{H}$ & 11 & 15 & 22 & 14 & 29 & 14 \\
\hline 21 & matK+intron $\mathrm{L}+t r n \mathrm{H}$ & 8 & 13 & 18 & 13 & 22 & 12 \\
\hline 22 & $r b c \mathrm{~L}+n d h \mathrm{~F}+$ intron $\mathrm{L}$ & 5 & 13 & 19 & 16 & 25 & 15 \\
\hline 23 & $r b c \mathrm{~L}+n d h \mathrm{~F}+t r n \mathrm{H}$ & 5 & 13 & 17 & 13 & 25 & 13 \\
\hline 24 & $r b c \mathrm{~L}+$ intron $\mathrm{L}+$ trn $\mathrm{H}$ & 0 & 7 & 12 & 12 & 18 & 12 \\
\hline 25 & $n d h \mathrm{~F}+$ intron $\mathrm{L}+t r n \mathrm{H}$ & 3 & 10 & 17 & 15 & 24 & 14 \\
\hline 26 & matK $+r b c \mathrm{~L}+n d h \mathrm{~F}+$ intron $\mathrm{L}$ & 12 & 15 & 26 & 15 & 30 & 15 \\
\hline 27 & $m a t \mathrm{~K}+r b c \mathrm{~L}+n d h \mathrm{~F}+t r n \mathrm{H}$ & 11 & 15 & 24 & 14 & 27 & 14 \\
\hline 28 & matK $+n d h \mathrm{~F}+$ intron $\mathrm{L}+$ trn $\mathrm{H}$ & 11 & 15 & 20 & 14 & 28 & 15 \\
\hline 29 & $r b c \mathrm{~L}+n d h \mathrm{~F}+$ intron $\mathrm{L}+t r n \mathrm{H}$ & 7 & 13 & 22 & 15 & 26 & 14 \\
\hline 30 & $\begin{array}{l}\text { matK }+r b c \mathrm{~L}+n d h \mathrm{~F}+\text { intronL } \\
+\operatorname{trnH}\end{array}$ & 12 & 15 & 24 & 14 & 30 & 14 \\
\hline
\end{tabular}


The best discrimination power among the single loci tested with NJ was obtained with matK, since all the species could be distinguished except two groups of two species (Annona cherimola - A. pruinosa and A. liebmaniana - A. pittieri). After matK, ndhF had the best discriminatory power, followed by the intron trnL, $t r n \mathrm{H}-p s b \mathrm{~A}$ and $r b c \mathrm{~L}$. In Figure $3.1 \mathrm{a}$ and $\mathrm{b}$ the most supported ML (16) and BA (16) trees are shown respectively obtained in both cases by the combination of matK $+r b c \mathrm{~L}+n d h \mathrm{~F}$ genes.

In the case of $\mathrm{ML}$, there was another combination (26: matK $+r b c \mathrm{~L}+n d h \mathrm{~F}+$ intron $t r n \mathrm{~L})$ with the same number of robust nodes with a very similar topology. In both of them, 15 species, present monophyly at the species level. $A$. pruinosa and $A$. cherimola individuals clustered in almost all trees in the same branch. One $A$. cherimola accession of Mexican origin is mixed with the $A$. pruinosa individuals while the rest of the $A$. cherimola samples (having the Honduran ones in the base) clustered together in one branch. The $\mathrm{ML}$ optimization likelihood of the represented tree was -4565.21 , while the combined log likelihood of each cold chains, of each Markov run in the BA were -4554.44 and -4554.48 .

\section{DISCUSSION}

Annonaceae is the largest family within the Magnoliales in the angiosperm Magnoliid clade (APG III 2009). It includes about 110 genera and 2400 species of pantropical distribution. Usually four main clades are distinguished in the family; two of these clades form a heterogeneous basal grade, whereas the other larger two clades are known as the 'long branch clade' (LBC) and 'short branch clade' (SBC) since they reflect differing rates of nucleotide substitutions (Richardson et al. 2004; Pirie et al. 2005). Recently, Chatrou et al. (2012) distinguished four subfamilies (Anaxagoreoideae, Ambavioideae, Annonoideae and Malmeoideae) and 14 tribes. The Annona genus, which includes around 162 species, belongs to the subfamily Annonoidae and the tribe Annoneae placed in the LBC. A total of 8 genera are included in the Annoneae: Annona, Anonidium, Asimina, Boutiquea, Diclinanona, Disepalum, Goniothalamus and Neostenanthera.

In this study 17 species of Annona were analyzed. Five of them are included in the Atta section (representing $45 \%$ of the species included in the section) whereas the rest belong to other taxonomically close sections (Chalenocarpus, Ilama, Annona, Uloterpus, Phelloxylon, Helogenia and former Rollinia). Contrary to expectations not all the species of the Atta section showed monophyly but paraphyly since the individuals of the five species of the section studied (A. cherimola, A. pruinosa, A. squamosa, A. reticulata, A. longiflora), clustered with $A$. liebmaniana, $A$. pittieri (Chalenocarpus section) and $A$. macroprophyllata (Ilama section) in the same clade. Thus, the sections Atta, Chalenocapus and Ilama (all species included in those sections except $A$. cherimola have exclusively a Mesoamerican and 
Caribean natural distribution) seem to define a monophyletic group making necessary a new arrangement of these sections within the genus based on molecular markers. In order to get additional information on the debated origin of $A$. cherimola, 13 individuals of $A$. cherimola originating from different geographical areas where included in the analysis. Most authors have considered the Andean region as the center of origin of the species (Popenoe 1921; Bonavia et al. 2004) although recent biogeographical studies with SSR markers show higher genetic diversity values in accessions from Mesoamerican countries supporting the hypothesis of a Central American origin of $A$. cherimola. The observation of a monophyletic group with all species of Central American origin and the way the $A$. cherimola individuals clustered are in concordance with results recently obtained based on nuclear molecular markers (Larranaga et al. under revision, chapter 4).

The $A$. cherimola and the $A$. pruinosa individuals analyzed in this work showed to have a common ancestor. A. pruinosa showed paraphyly since the two representative individuals of this species and an A. cherimola accession of Mexican origin were at the base of this branch. This lack of reciprocal monophyly among these two sister species could be due to a recent diversification since only after sufficient complementary haplotype extinction, species can be recovered as monophyletic with respect to each other (Kizirian \& Donnelly 2004).

Three different approaches have been carried out for the alignment analyses. First NJ trees with the Kimura 2 parameters model were obtained with all alignments and concatenations. This method was been widely used in DNA barcoding studies (De Vere et al. 2012; Nicolas et al. 2012, Zhang et al. 2015) for the discrimination/identification among species, although it has also been criticized (Srivathsan \& Meier 2012; Collins \& Cruickshank 2013). Recently, Larranaga and Hormaza (2015) showed how matK sequences could discriminate among 12 different species and polymorphisms were used to design new specific primers for the 7 most commonly cultivated Annona species. The results obtained in this work also showed how matk performed the best among the chloroplast regions analyzed, although two groups of two species (Annona cherimola - A. pruinosa and A. liebmaniana - $A$. pittieri) could not be discriminated with this region. After matK, ndhF had the best discriminatory power, followed by the Intron trnL, $t r n \mathrm{H}-p s b \mathrm{~A}$ and $r b c \mathrm{~L}$. Using this technique, combinations of $2,3,4$, and 5 chloroplast regions that included matK and $n d h F$ could separate 15 out of 17 species, all except $A$. cherimola and $A$. pruinosa. 


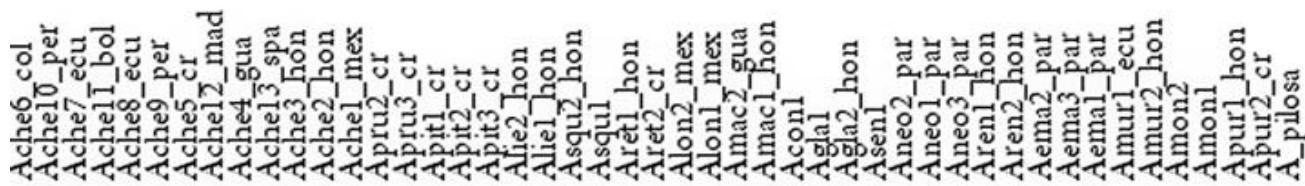

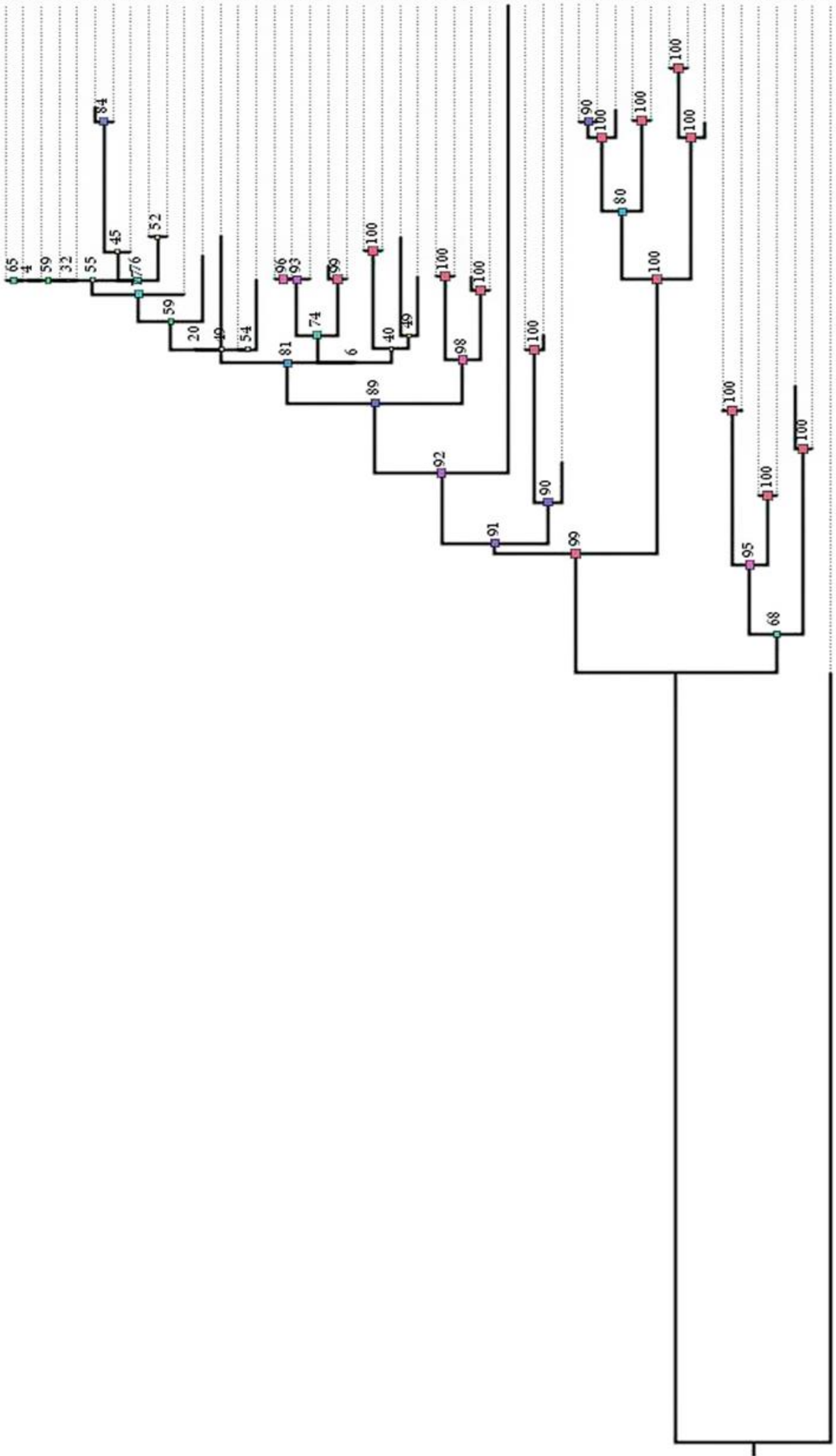

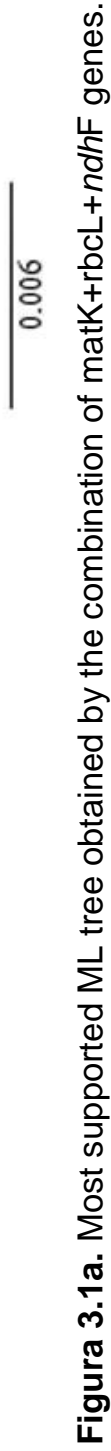



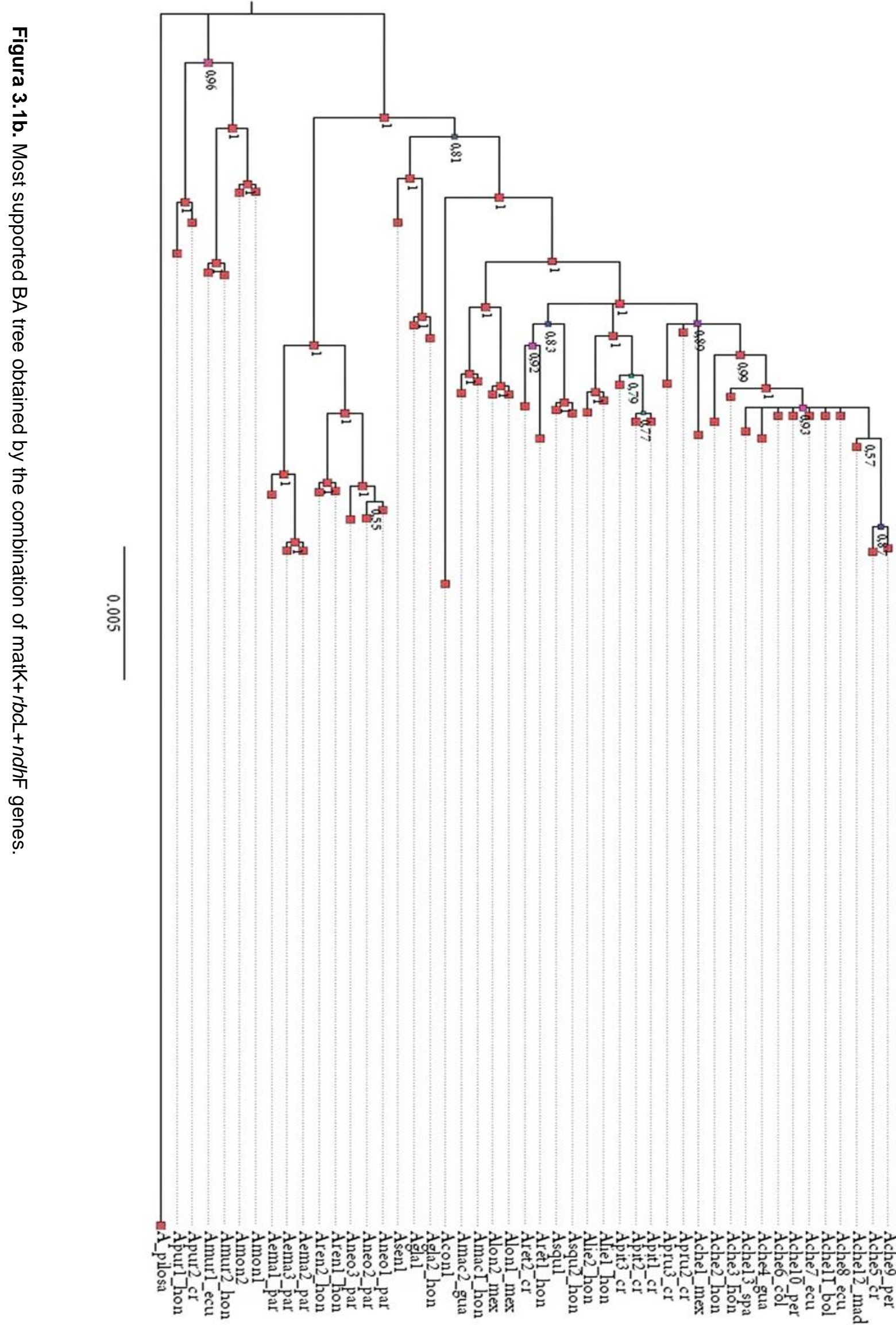
Maximum likelihood phylogenetic analyses performed in RaxML were also applied. Maximum likelihood analyses calculate the probability of the data given a certain tree (hypothesis) and a model substitution. Nodes with higher support were generally obtained with this method. NdhF followed by matK showed more supported nodes and more monophyletic groups at the species level. Two trees (16; matK $+r b c L+n d h F$ (Figure 3.1) and 26; matK $+r b c \mathrm{~L}+n d h \mathrm{~F}+$ intron $t r n \mathrm{~L})$ showed most supported nodes with same topology. In addition two trees (3; ndhF and $22 ; r b c \mathrm{~L}+n d h \mathrm{~F}+$ intron $t r n \mathrm{~L})$ were able to separate individuals of $A$. cherimola in a monophyletic branch, but with poor bootstrap values (26 and 47 respectively).

Finally, the Bayesian analysis calculates the posterior probability, the probability of a certain tree/hypothesis given the data and an evolutionary model. Mr Bayes permitted to construct trees with higher number of nodes supported with a posterior probability over $80 \%$ compared with bootstrap values of previous analysis. Again alignments with matK and $n d h F$ alone produced the trees with the highest support, while the best combination in terms of support and monophyly of species was the combination of the three coding regions utilized (tree 16; matK $+r b c L+n d h F$ ). All trees obtained with this analysis presented $A$. pruinosa and $A$. cherimola in the same clade, not showing reciprocal monophyly in any case.

MatK and $n d h F$ sequence alignments which presented 11 and $21 \%$ of variable characters seemed to be the best for species resolution regardless of the method of analysis. Although the non-coding regions (intron $t r n \mathrm{~L}$ and $t r n \mathrm{H}-p s b \mathrm{~A}$ ) showed 15 and $24 \%$ of variability they resulted in trees with less resolution and support.

The phylogenetic study performed in this work focused on a particular Annona section, Atta, shows the necessity of performing further studies on the species distribution in this and closely related sections last described in Fries (1959). Moreover, A. cherimola and $A$. pruinosa seem to be very closely related since the methods used here could not show a different history of this two species, making necessary additional comparative studies. 


$$
20
$$




\title{
A MESOAMERICAN ORIGIN OF CHERIMOLA (ANNONA CHERIMOLA MILL.). IMPLICATIONS FOR THE CONSERVATION OF PLANT GENETIC RESOURCES
}

\begin{abstract}
Knowledge on the structure of genetic diversity is a key aspect in order to plan and execute an efficient conservation and utilization of the genetic resources of any crop. In this work, a large data set of 1765 accessions of cherimoya (Annona cherimola Mill), an underutilized fruit tree crop native to the Neotropics and used as a food source by pre-Columbian cultures, collected along the American continent has been studied with microsatellite markers and geographic information systems. The fine representation of the spatial distribution and structure of genetic diversity obtained suggests, contrary to previous reports, a Mesoamerican origin of the crop with clear implications for the exchange of plant germplasm between Central and South America in pre-Columbian times. These results together with the potential distribution of the species in a climatic change context provide new insights for the conservation of genetic resources of cherimoya and other fruit crops in the Americas.
\end{abstract}

\section{INTRODUCTION}

“There are two things in Lima which all travelers have discussed; the ladies 'tapadas', or concealed in the saya and manta, and a fruit called chilimoya. To my mind the former is as beautiful as the latter is delicious [...]". These words written by a young Charles Darwin during the last stopover of the Beagle on the South American continent in Lima (Peru) in 1835 before heading for the Galapagos islands (Darwin 1835) suggest that at that time cherimoya (Annona cherimola Mill.) fruit was well known in the Andean region. That fact together with the presence of putative wild cherimoya populations in Northern Peru and Southern Ecuador and archaeological discoveries of ancient vessels resembling cherimoya fruits and seeds have resulted in the general consideration of the Andean region as the center of origin of the species (Popenoe 1921; Bonavia et al. 2004). Consequently, most efforts to preserve the genetic resources of cherimoya have been focused on accessions collected in South America. However, the possibility that these putative wild cherimoya stands are indeed feral populations cannot be excluded and, moreover, the archaeological remains of cherimoya-like structures in South America could actually correspond to a sister species, guanabana (Annona muricata) (Pozorski \& Pozorski 1997). In addition, A. cherimola is the only representative of the Atta section of Annona growing naturally in South America. The rest of the closely related species within this clade occur exclusively in Mesoamerica and Southern Mexico. In fact, cherimoya was surely already present in Central America at least in the seventeenth century (Cobo 
1653). Moreover, different common names are used for $A$. cherimola in Central and South America. In South America the crop is known in Spanish as "chirimoya", a word probably derived from a quechua word which could mean "cold fruit or seed" (Pozorski \& Pozorski 1997; Bonavia et al. 2004). In Central America, the common word for cherimoya and other closely related species is anona. Interestingly, Linnaeus used the vernacular Central American designation to name the genus but referred to it as derived from the Latin word "annona" that can be translated as "the harvest of a year" (Linnaeus 1737).

A clear picture of the structure of genetic diversity is needed for efficient conservation of the genetic resources of any crop, which is fundamental for guaranteeing food security for future generations. This is becoming increasingly important in the current scenario of global climatic change where conserving genomic pools of biological diversity will be critical to develop cultivars resilient to a wide range of biotic and abiotic stresses. To date, conservation of plant genetic resources worldwide has been concentrated on a very small group of species. Thus, from about 7,000 plant species that have been used by humans (Hammer 2003) and the 2500 that have undergone domestication (Meyer et al. 2012), currently about 30 species contribute to more than $90 \%$ of human nutrition globally, and just three cereals (wheat, rice and maize) account for about two thirds of human dietary needs (Cassman 1999). Genetic erosion is even more dramatic in neglected or underutilized species (NUS), such as cherimoya, many of them present in developing or underdeveloped countries, with great potential for food and nutrition security (Padulosi et al. 2002).

The cherimoya belongs to the Annonaceae, an extremely diverse family within the Magnoliales with approximately 110 genera and 2400 species, 900 of them found in the neotropics (Chatrou et al. 2012). Nowadays this species diversity is mainly conserved in traditional agricultural systems as backyards and living fences of rural areas, in Central America, Mexico and South America between 1000 and 3000 masl, with few or nonmanagement. As other crop of Mesoamerica, it is grown and sold in the local scale and have not yet undergone intensive selection and large scale cultivation characteristic of modern agriculture (Miller \& Schaal 2005). Propagation among cultivated specimens is mainly mediated by seeds, vegetative propagation by cutting is very poor except in the few selected cultivars commercially produced. Cherimoya fruits have excellent organoleptic and nutritive qualities. Interest in cherimoya and other species of the Annonaceae has increased in recent years due to the presence of acetogenins, compounds found only in this family with cytotoxic, antitumor, antimalarial, and pesticide properties (Alaly et al. 1999; Liaw et al. 2011). Spain is the most important commercial producing country of cherimoyas in the world with about 3,000 has and commercial production is also important near Lima in Peru and in Chile and, to a 
limited extent, in other countries such as Ecuador, Bolivia, Colombia, Portugal, USA, Argentina or Mexico (Galán Sauco et al. 2014).

van Zonneveld et al. (2012) studied genetic diversity of cherimoya in Ecuador, Peru and Bolivia using different microsatellite loci. The most diverse spots were located in Southern Ecuador and Northern Peru. Following Vavilov's idea that centers of crop diversity indicate their geographical centers of origin (Dvorak et al. 2011), these results would corroborate the hypothesis of the origin of the species in the Andean region, taking into account that, as most NUS and vegetativelly propagated crops in which limited breeding has occurred (Zohary 2004), cultivated cherimoya is probably very few generations separated from its wild ancestors. In order to test this hypothesis of the center of origin of the species, in this work those samples previously analyzed from South America were compared with additional samples collected in Central America, resulting in a final database of 1765 cherimoya samples analyzed along the American continent. The results obtained from the diversity analyses together with the potential future distribution in a climate change context will allow the prioritization of the most vulnerable areas for in situ and ex situ conservation of cherimoya germplasm and would provide additional information about how this and other crop resources could have been handled in pre-Columbian times.

\section{MATERIALS AND METHODS}

\section{Plant material, DNA extraction and amplification}

Leaves from 262 A. cherimola Mill. trees were collected in the highlands (900 to 3000 meters above sea level) of Guatemala, Honduras and Costa Rica and geopositioned in decimal grades. Most of the samples were collected in private or community orchards in which usually no proper tree management was performed while some were collected apparently in a wild state. The study combined these samples with 1,503 additional DNA samples obtained from different trees from Ecuador, Peru and Bolivia (van Zonneveld et al. 2012). The geographical distribution of the 1,765 specimens analyzed is shown in Figure 4.1.

One sample of Annona pittieri from Costa Rica was used as outgroup. DNA extraction was performed following Viruel and Hormaza (2004). Nine microsatellites previously shown to be highly informative in A. cherimola (Escribano et al. 2008b; van Zonneveld et al. 2012) were used: LMCH1, LMCH4, LMCH16, LMCH48, LMCH69, LMCH87, LMCH122, LMCH139 and LMCH144. Each PCR reaction contained $16 \mathrm{mM}(\mathrm{NH} 4) 2 \mathrm{SO} 4,67 \mathrm{mM}$ Tris- $\mathrm{HCl} \mathrm{pH} 8.8,0.01 \%$ Tween® 20, $3 \mathrm{mM} \mathrm{MgCl} 2,0.1 \mathrm{mM}$ of each dNTP, $0.3 \mu \mathrm{M}$ of each primer, $20 \mathrm{ng}$ of genomic DNA and 1 unit of BioTaq ${ }^{\mathrm{TM}}$ DNA polymerase (Bioline, London, UK) in a final volume of $15 \mu \mathrm{l}$. $\mathrm{PCR}$ reactions were carried out in an I-cycler (Bio-Rad Laboratories, Hercules, CA, USA) 
thermocycler using the following temperature program: an initial step of $1 \mathrm{~min}$ at $94^{\circ} \mathrm{C}, 35$ cycles of $30 \mathrm{~s}$ at $94^{\circ} \mathrm{C}, 30 \mathrm{~s}$ at $55^{\circ} \mathrm{C}$, and $1 \mathrm{~min}$ at $72^{\circ} \mathrm{C}$, and a final step of $5 \mathrm{~min}$ at $72^{\circ} \mathrm{C}$. Forward primers were labeled with a fluorescent dye on the 5-end and PCR products were detected and sized with a Beckman Coulter Genome Lab ${ }^{T M}$ GeXP capillary DNA analysis system. Samples were denaturalized at $90^{\circ} \mathrm{C}$ for 120 seconds, injected at $2.0 \mathrm{kV}, 30$ seconds, and separated at $6.0 \mathrm{kV}$ for $35 \mathrm{~min}$. A range of samples with the encountered alleles was used as positive controls, to guarantee size accuracy and to minimize run-to-run variation. Each PCR reaction and capillary electrophoresis was repeated at least twice to ensure the reproducibility of the results.

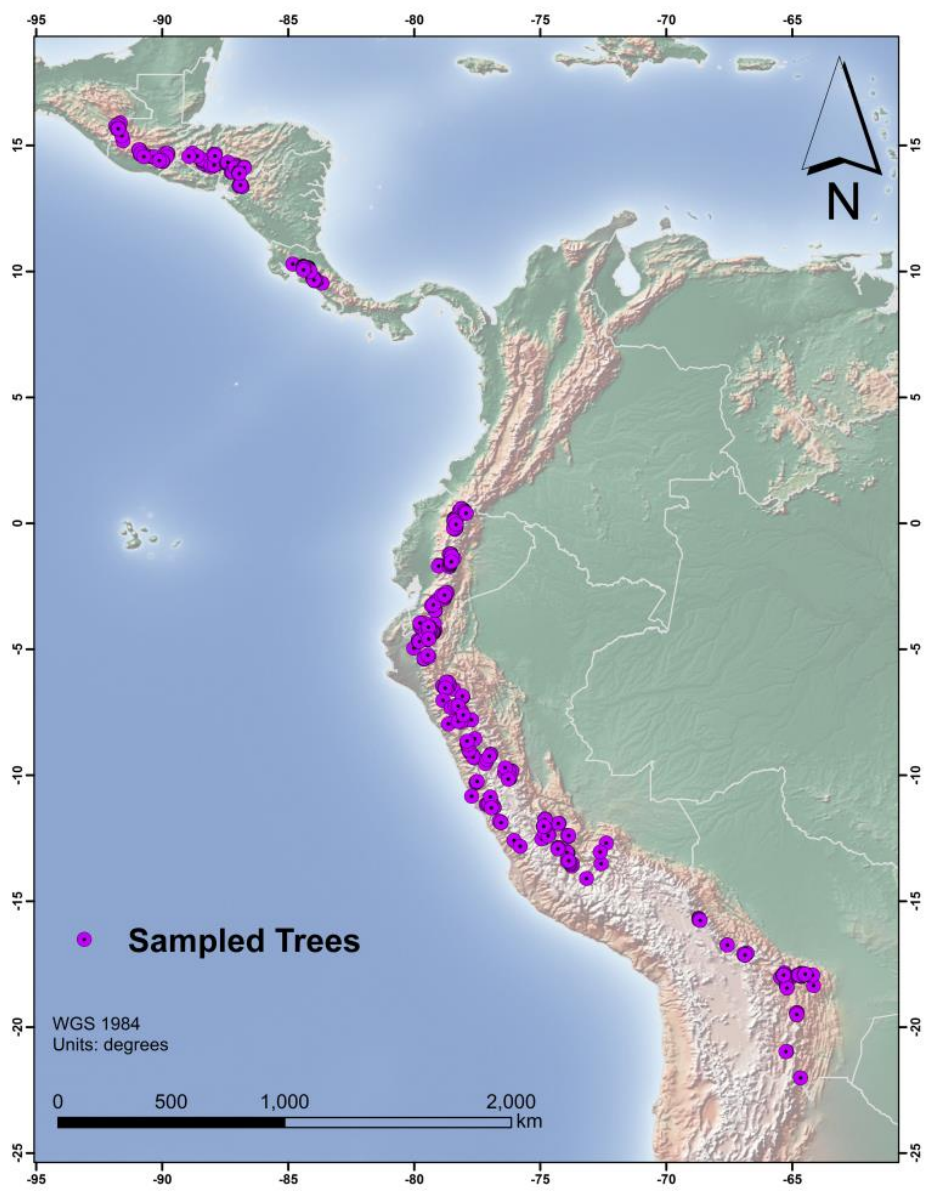

Figure 4.1. Geographic distribution of the 1,765 Annona cherimola samples analyzed in the present study.

\section{Genetic diversity}

Calculation of genetic diversity parameters was done using the grid-based procedure described previously (Thomas et al. 2012a; van Zonneveld et al. 2012). These parameters were allelic richness per locus, expected and observed heterozygosities, and the Shannon information index. Grid-based spatial diversity analyses were performed using 10 minute grid 
cells (18 km at the equator) as the unit of analyses. Circular neighborhood of 60 minutes diameter was applied to every sample in order to achieve a continental work scale assuming that each genotype is representative for the circular area of the mentioned diameter $(111 \mathrm{~km}$ at the equator) around it. This replication exercise resulted in a total of 50,218 data points. The sample size was set to be equal or superior to the first quartile of the distribution of the number of trees per grid cell, i.e. 7 trees or 14 gene copies. For each of the retained grid cells $(1,231)$, genetic diversity parameters were calculated and averaged on bootstrapped subsamples (without repetition). Calculations were performed in R. ArcMap 10.1 was used to map and visualize the results and to calculate basic statistics (minimum, maximum, mean and standard deviation) per parameter. WGS 84 geographical projection was settled, layer with country boundaries downloaded from the DIVA GIS web page and layer 1:10 Cross-blended Hypsometric Tints from Natural Earth was used.

\section{Genetic structure}

Different approaches were utilized to evaluate the genetic structure of the $A$. cherimola samples analyzed along the American continent. First, a rooted neighbor joining tree was constructed based on the Dice similarity matrix using the software NTSYSpc 2.11 (Exeter Software, Stauket, N.Y.). The resulting figure was plotted with FigTree (http://tree.bio.ed.ac.uk/software/figtree/) using different tip colors to differentiate samples from each country.

Second, the software Structure (Pritchard et al. 2000), which carries a Bayesian analysis assuming Hardy-Weinberg equilibrium and linkage equilibrium between loci within populations, was used to determine the number of possible populations and the probability of each sample belonging to each population. The program was run 5 times, setting $\mathrm{K}$ (number of populations) from 1 to 10 with the admixture model and 5 replications per K. Each run was implemented with a burn-in period of 20,000 steps followed by 200,000 Monte Carlo Markov Chain replicates (Pritchard et al. 2010; Martin et al. 2011). Evanno's (Evanno et al. 2005) algorithm, in which an ad hoc statistic, $\Delta \mathrm{K}$, that estimates the optimal number of populations is calculated, was applied in order to determine the optimum number of populations.

The R package Adegenet (Jombart 2008) was also used. It runs the K-means algorithm for increasing values of $\mathrm{K}$. The classification of each individual into a determinate cluster was obtained by the Discriminant Analysis of Principal Components $(K)$. Both Structure and Adegenet samples membership probability for $\mathrm{K} 1$ to 6 was plotted using DISTRUCT (Rosenberg 2004) ordering samples per country and from North to South. 
Total number of alleles and their sizes were enlisted. In addition, alleles from Central and South American samples were compared. Finally, alleles of South American samples that clustered in the Structure and Adegenet (Kmeans + DAPC) results $(K=2)$ with Central America were also analyzed.

\section{Central American distribution in a context of climate change}

The MaxEnt software, which uses maximum entropy modeling to predict the species geographic distribution on the basis of the species environmental niche (Phillips et al. 2006), was run. A systematic resampling was executed among the 1,765 samples in order to reduce the aggregation of presence points (Fourcade et al. 2014). A grid of $2.5 \%$ side cell of the total extension of all data points was constructed and one point per cell selected, resulting in a new training data set of 46 , used to construct the models; 10 different training and test data sets were obtained to make results more consistent and validate the model. The mean of the area under the ROC curve (AUC) values for 10 training/test models obtained by cross validation with the maxent model was compared to 10 null models obtained by the Inverse Distance Weighted method using same training and test data sets. Background points were resampled for the construction of both types of models. Current 19 bioclimatic 2.5 minute cell resolution variables were downloaded from Worldclim (http://www.worldclim.org/). To remove highly correlated climate variables, a Pearson correlation was carried out following Brown (2014) eliminating all variables that showed $r^{2} \geq 0.8$ (Shrestha \& Bawa 2014). Thus, 9 variables were used: Bio1, 2, 3, 5, 12, 14, 15, 18, 19. For future climate projections, the same variables with the same resolution were used under two scenarios of global climate models of the four published by the Intergovernmental Panel on Climate Change (IPCC) Fifth Assessment Report (AR5): Representative Concentration Pathway (RCP) 4.5 and 8.5. RCP 4.5 is a stabilization scenario in which total radiative forcing is stabilized shortly after 2,100 , while RCP 8.5 is characterized by increasing greenhouse gas emissions over time (Wayne 2013). Two global circulation models, HadGEM2-CC (HG) (Hadley Global Environment Model 2 Carbon Cycle) (Collins et al. 2011; Shrestha \& Bawa 2014) and MRI-CGCM3 (MG) of the Meteorological Research Institute (Yukimoto et al. 2012) for the year 2,070, were selected. Binary current and future projected potential distribution areas were obtained with a maximum training sensitivity plus specificity threshold (Liu et al. 2005). In order to display the stable, jeopardized and new areas of cherimoya distribution in Central America and Southern Mexico, current and future models were overlayered. All operations were done with $\mathrm{R}$ using the following packages: raster (Hijmans \& van Etten 2012), dismo (Hijmans et al. 2011), maptools (Bivand \& Lewin-Koh 2015), maptree (White \& Gramacy 2012), rgeos (Bivand \& Rundel 2015), rJava (Urbanek 2013) and rgdal (Bivand et al. 2014). Resulting maps were displayed 
using the ArcGis 10.1, WGS 84 geographical projection was settled, layered with country boundaries downloaded from the DIVA GIS web page (www.diva-gis.org) and 1:10 Crossblended Hypsometric Tints layer from Natural Earth was used.

\section{RESULTS}

\section{Genetic diversity}

Genetic diversity parameters measured within the selected 1,231 grids are shown in Figure 4.2. Figure $4.2 \mathrm{a}$ shows one of the most used parameters in genetic diversity studies and conservation genetics, allelic richness (AR), i.e. the average number of alleles per locus (Foulley \& Ollivier 2006) and per grid encountered. This parameter varied from 2.32 to 7.33 , with a mean of 3.62 and standard deviation of 1.18 . Figure $4.2 \mathrm{~b}$ shows the Shanon Index (SI), which takes into account allele numbers and frequencies (Ernest et al. 2014). Its values varied from 0.63 to 1.8 , with a mean of 1.0 and a standard deviation of 0.29 . Expected and Observed Heterozygosities $\left(\mathrm{H}_{e}, \mathrm{H}_{\mathrm{o}}\right)$ are shown in Figure $4.2 \mathrm{c}$ and $4.2 \mathrm{~d}$ respectively. $\mathrm{H}_{\mathrm{e}}$ values varied from 0.38 to 0.80 , with a mean of 0.55 and a standard deviation of 0.11 . Ho varied from 0.27 to 0.86 , with a mean of 0.54 and a standard deviation of 0.13 . In all cases, the grids with the highest values were located in Honduras and Guatemala and the lowest mainly in Bolivia and Southern Peru. High levels of heterozygosity are observed in central Peru, near Lima, which could be due to the presence (and introgression) of the heterogeneous commercially cultivated variety Cumbe as reported by van Zonneveld et al. (2012).

\section{Genetic structure}

The rooted neighbor joining tree constructed with the Dice similarity index is shown in Figure 4.3. It shows a clustering of the samples by geographical origin, differentiating Central from South American samples. Central American samples presented longer branches indicating higher distance values. Some samples from Peru clustered near those of Central America, while the rest appeared mixed in two main groups; one included mainly samples from Ecuador and Peru and the other from Peru and Bolivia. 

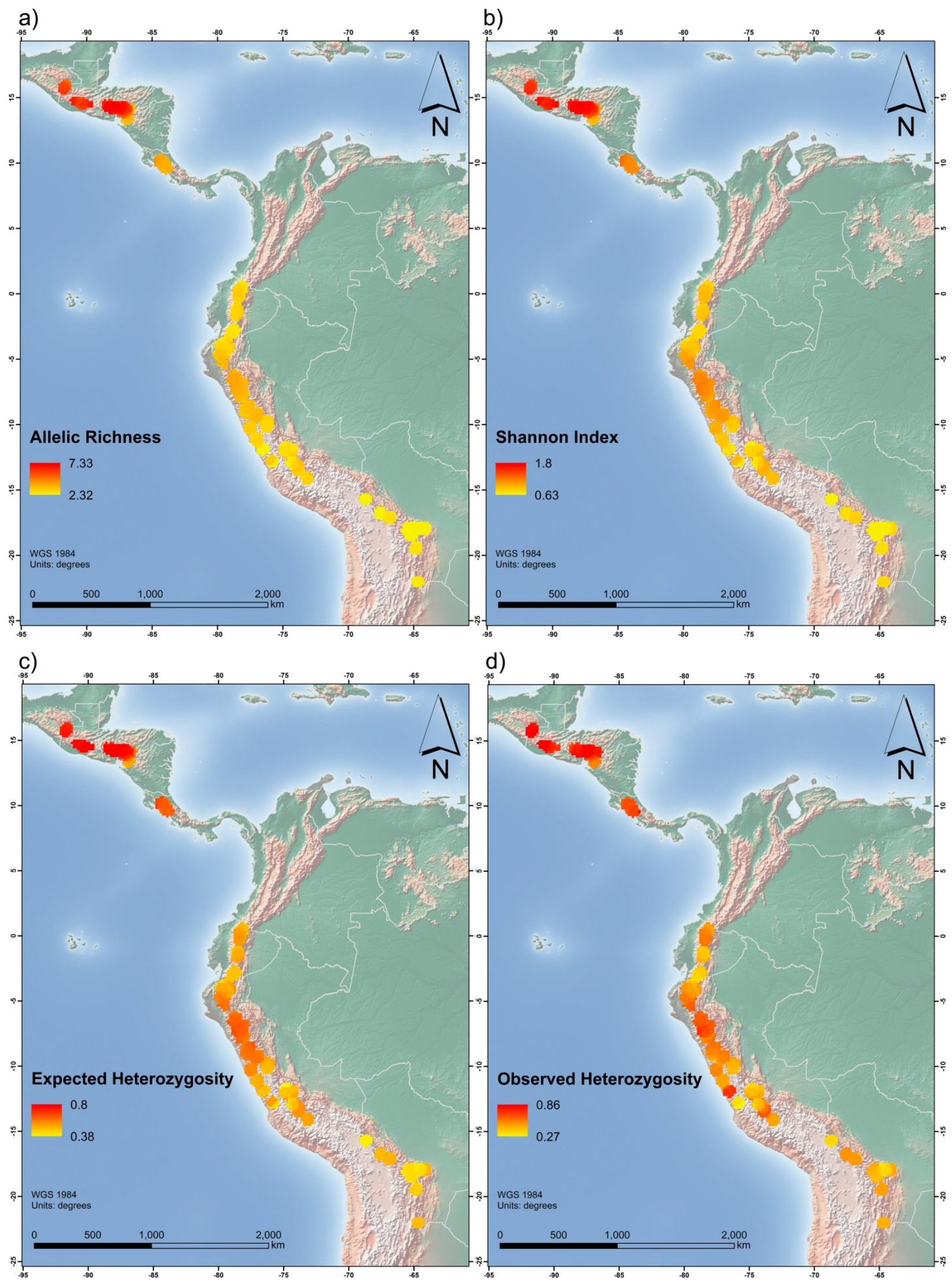

Figure 4.2. Genetic diversity parameters measured within the selected grids after applying circular neighborhood: 2a) Allelic richness, 2b) Shannon index, 2c) Expected heterozygosity, 2d) Observed heterozygosity. 
Assignation of samples to population probabilities provided by one randomly selected Structure and Kmeans + DPCA result for number of populations $(K)=2,3,4,5$ and 6 are shown in Figure 4.4a and 4.4b respectively. Results from these two approaches are very similar. For $K=2$, samples are divided in two populations (Central and South America) according to their origin, with the exception of a few samples from Northern Peru. The higher the number of populations, the more separated in different populations the samples from Peru are, following, in almost all cases, a geographical north-south pattern. After implementing Evanno's algorithm (Evanno et al. 2005) for the Structure results, the highest value of $\Delta \mathrm{K}$ was obtained for $\mathrm{K}=2$ followed by $\mathrm{K}=3$.

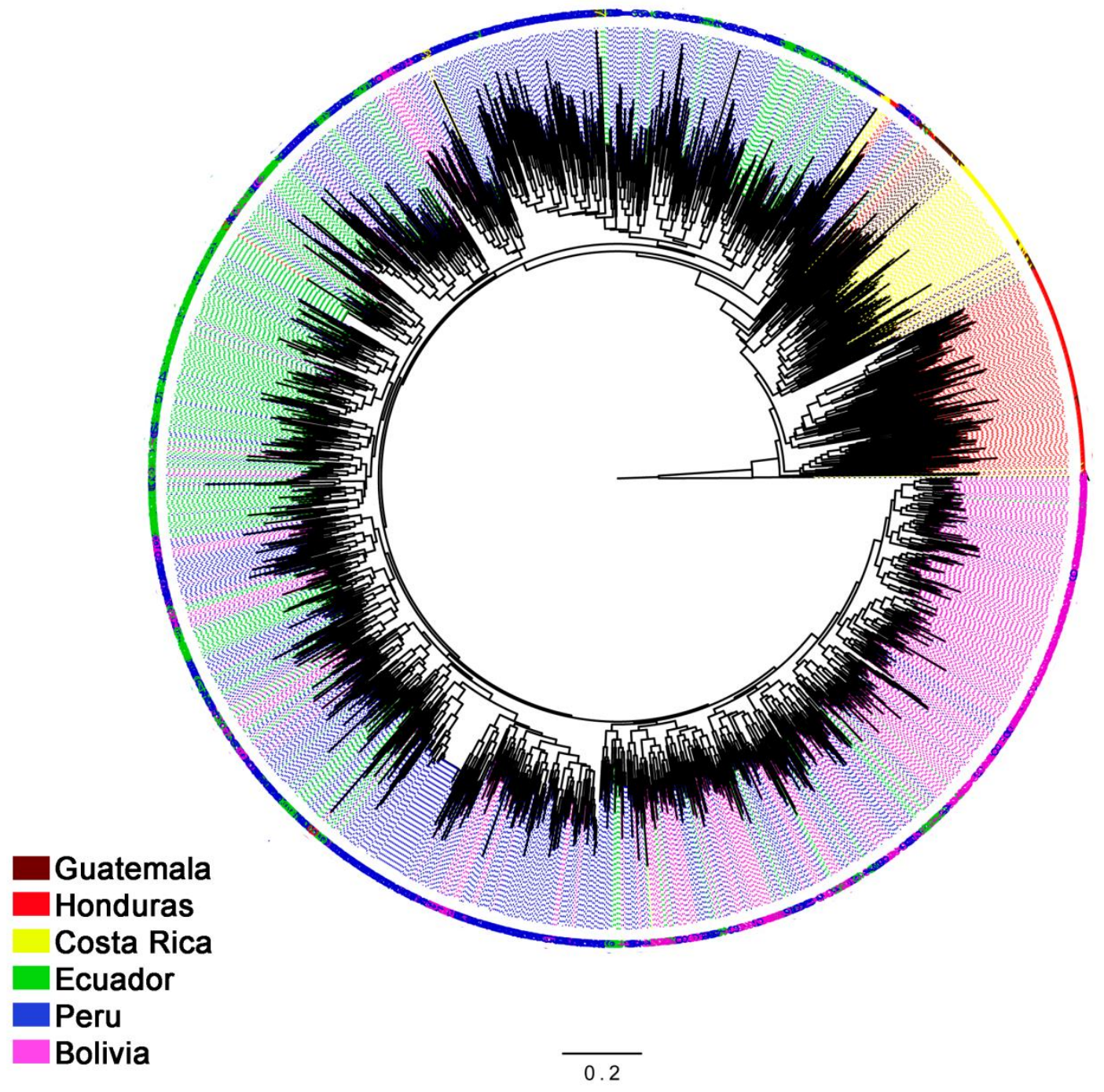

Figure 4.3. Rooted neighbor joining tree based on the similarity matrix obtained using the Dice index with the 1,765 Annona cherimola samples analyzed in the present study.

A total of 176 alleles were obtained, of which 172 (97.72\%) were present in Central American samples and 66 (37.5\%) in South American samples with 110 and 4 unique alleles present in the Central and South American samples, respectively. For $K=2$, samples 
collected in South America but assigned to the Central American population with a membership probability above 0.7 with Structure (14 samples) or Adegenet (Kmeans + Discriminant Analysis of Principal Components) (226 samples) showed 42 and 56 alleles respectively; this means $63.6 \%$ and $84.8 \%$ of all the alleles obtained in South American samples, respectively. Allele sizes are shown in Figure 4.5.
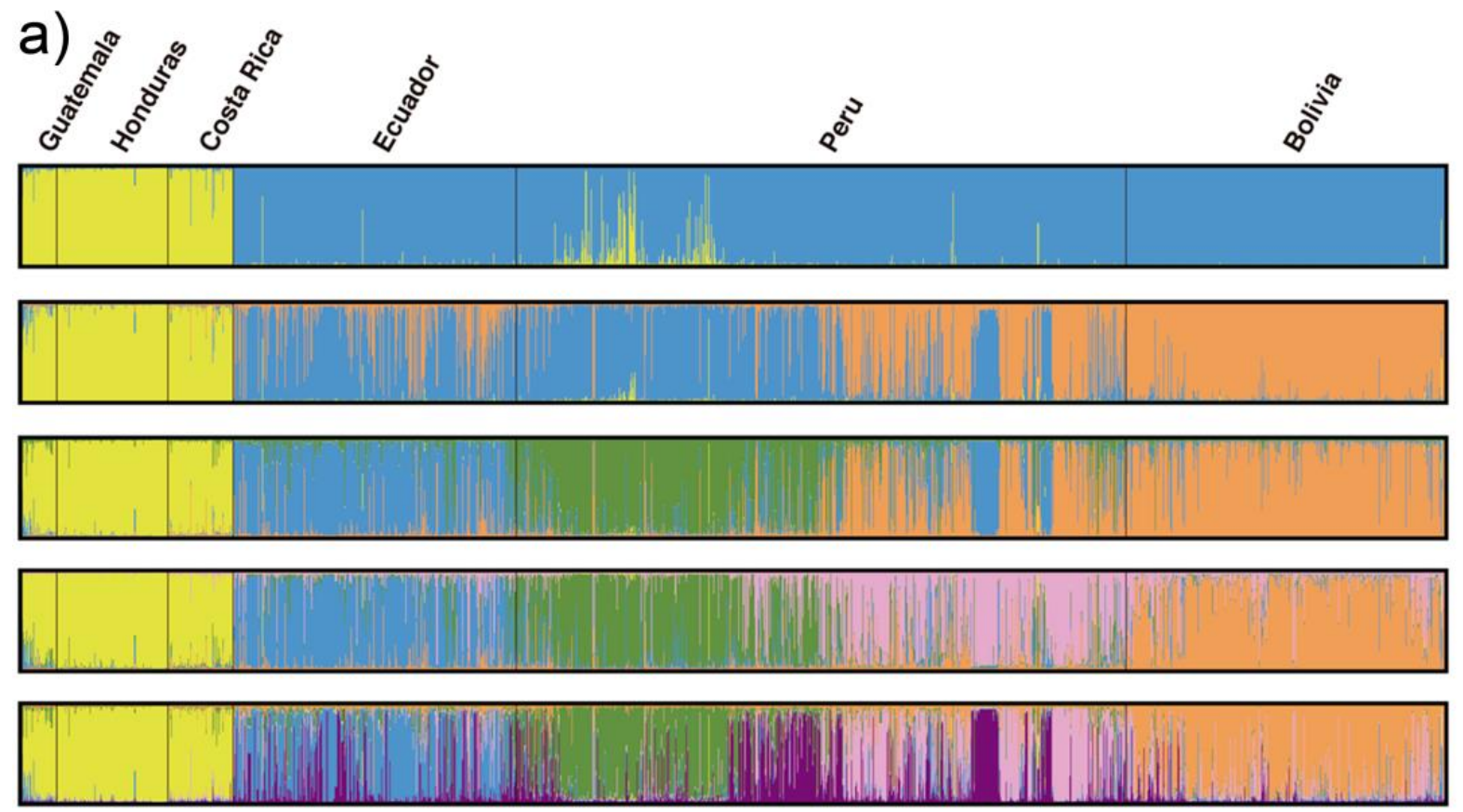

b)
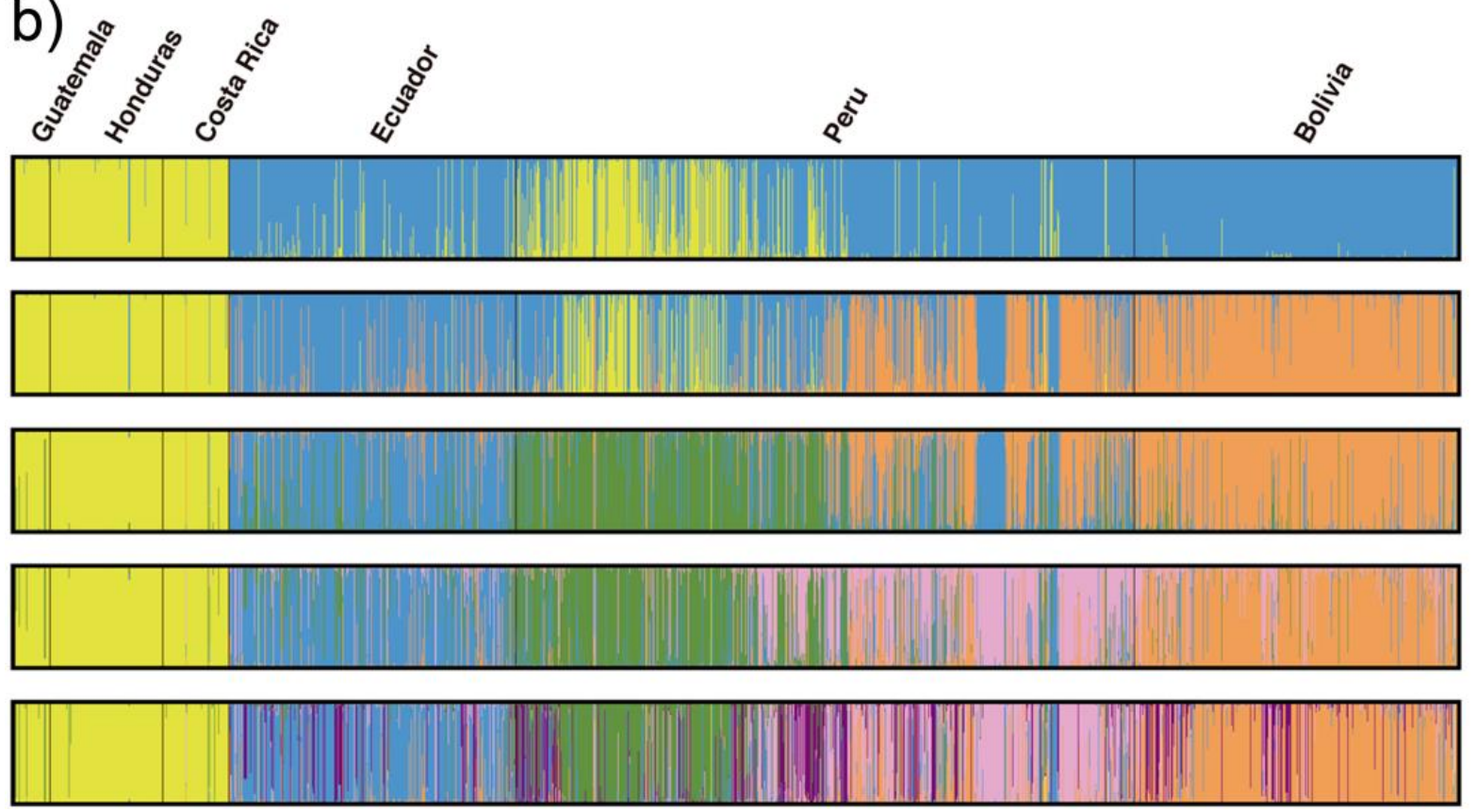

Figure 4.4. Assignation of probabilities of each sample to each cluster provided by one randomly selected 4.4a) Structure and 4.4b) Kmeans + DPCA result for $\mathrm{K}=2,3,4,5$ and 6 . Each accession is represented by a vertical line, its length indicates the probability of belonging to each cluster. Accessions are ordered according to country and latitude from North to South. 


\section{Potential distribution of $\boldsymbol{A}$. cherimola in Central America in a context of climate change}

Potential distribution of stable, jeopardized and new areas for $A$. cherimola in Central America and Mexico under current and future climatic conditions are shown in Figure 4.6a (RCP 4.5) and 4.6b (RCP 8.5) for the HG, and in Figure 4.6c (RCP 4.5) and 4.6d (RCP 8.5) for MG. AUC values for the null IDW model were already high: $0.92 \pm 0.02$ but the Maxent AUC results were even higher $0.97 \pm 0.01$ meaning this distribution model performed better. Predictions for 2070 using both climate models and two representative concentration pathways were very similar although more areas seem to be jeopardized when the climate model HG is used compared to MG. In both cases RCP 8.5 resulted in higher jeopardized areas, since this model assumes higher emission values and, thus, more intense climate warming. In general terms, $A$. cherimola distribution areas are lost in Honduras and eastern Guatemala and the common areas reduced to higher mountains. Just a few new areas are predicted to be gained: Western Guatemala, Central Mexico and Costa Rica.

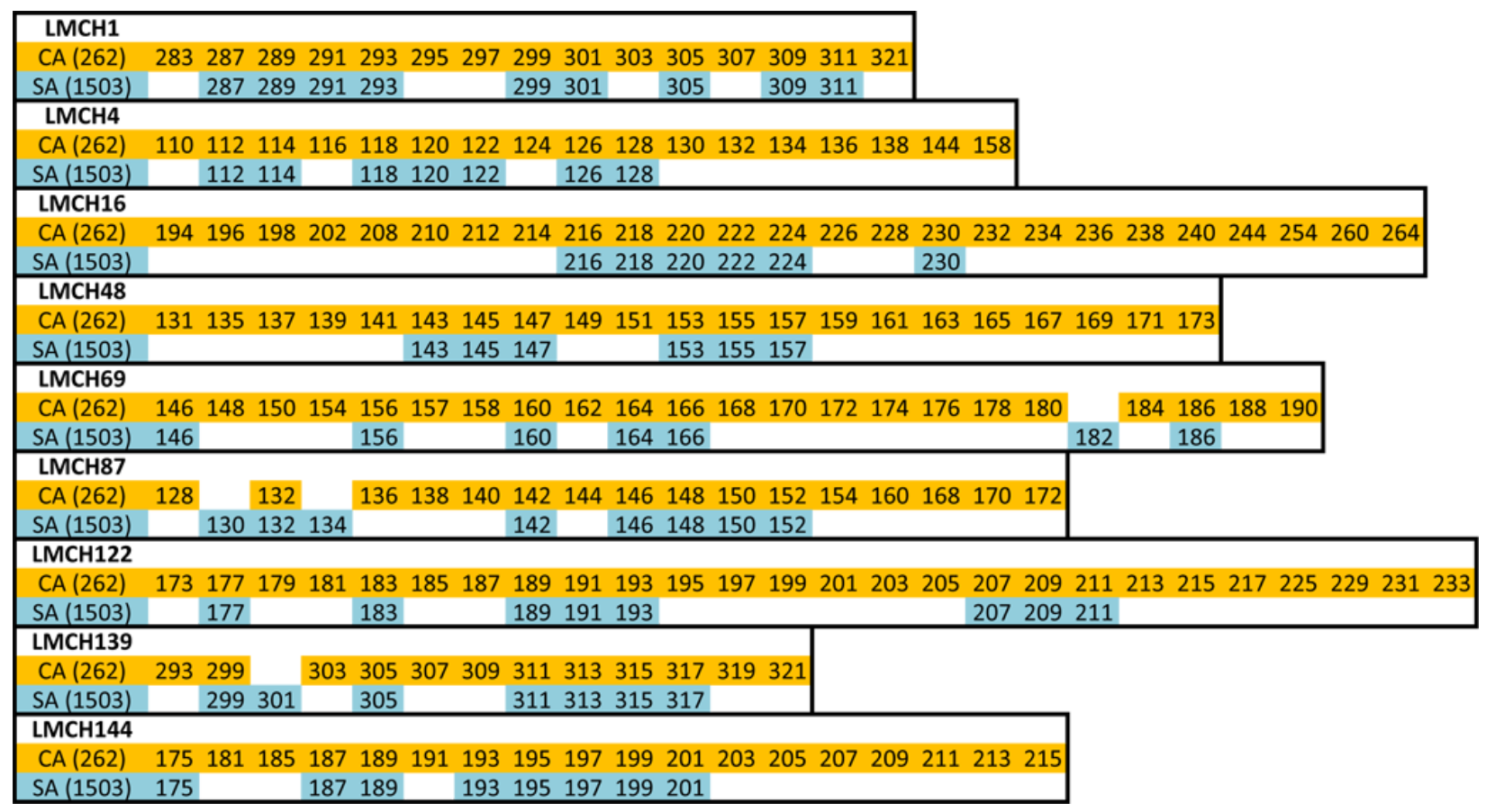

Figure 4.5. Microsatellite allele sizes found in Central American (yellow) and South American (blue) samples. 

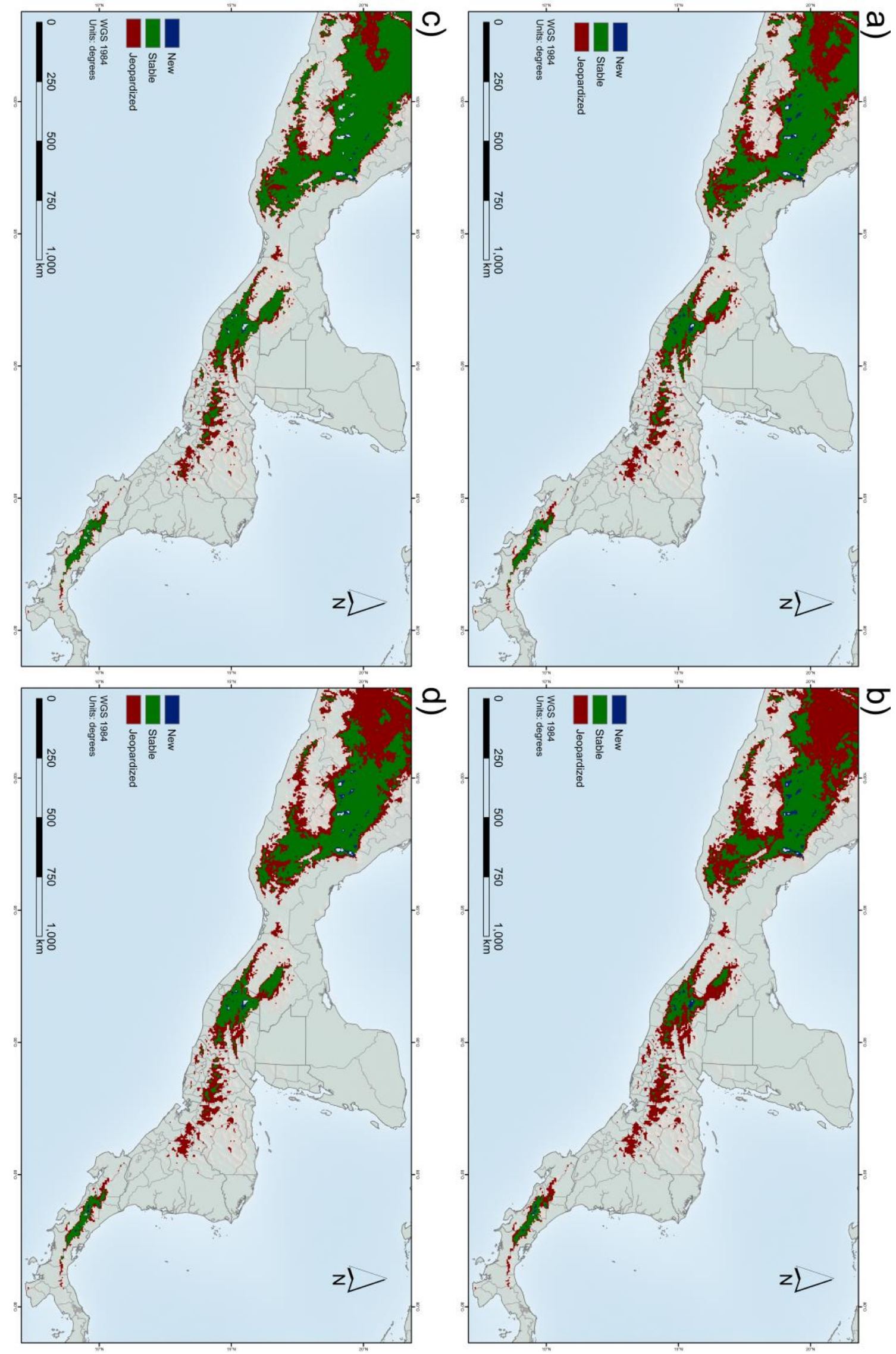

Figure 4.6. Potential distribution of stable, jeopardized and new areas for cultivation of $A$. cherimola in Central America and Mexico under current and future climatic conditions based on the model HG for 6a) RCP 4.5, 6b) RCP 8.5 and MG for 6c) RCP 4.5 and 6d) RCP 8.5. 


\section{DISCUSSION}

Genetic diversity studies, especially in NUS in which the extent of germplasm diversity is still largely unknown and the distribution of that diversity could reflect historical events, are of great importance for the use and conservation of crop germplasm. In this study, diversity of $A$. cherimola in Central and South America was studied with highly polymorphic nuclear DNA markers to address the origin of this crop. The highest values of diversity are located in Central America, mainly in Honduras and Guatemala, followed by Costa Rica. The values are lower in South America where a decrease is observed from Northern Peru both northwards (Ecuador) and southwards (Southern Peru and Bolivia). Consequently, our results strongly suggest a Mesoamerican origin of $A$. cherimola with a secondary center of diversity in the Andean region of South America.

The analyses of private alleles (alleles found in a single population) showed that all alleles (except four) present in South America are present in Central America and that a few samples in Northern Peru represent most of the alleles encountered in South America. Since those four alleles have size differences of just two bp with other alleles reported, it is possible that they could be also present in Central America but were not found in the current sampling. Before a mutant allele is either lost or migrated, it will be a private allele and would be found in just one of numerous populations in a large collection (Slatkin \& Takahata 1985). Szpiech and Rosenberg (2011) reported that private alleles tend to be found in the tails rather than in the interior of the allele size distribution. Here, private alleles of Central America are both in the tails and in the middle of the distribution, which could reflect a limited number of alleles distributed to South America from Central America.

The population structure results corroborate the hypothesis of cherimoya dispersal from Central America to Northern Peru and then to the rest of the Andean region, since NJ, Structure and Adegenet outputs showed that a few samples from Northern Peru are closer to the Central American samples than any other samples from South America. Structure and Adegenet outputs showed that the higher the number of populations we assume to have, the more separated in different populations the samples from South America are, following, in almost all cases, a geographical north-south pattern. After implementing Evanno's algorithm for the Structure results, the highest value of $\Delta K$ was obtained for $K=2$ followed by $K=3$. The last confirmed previous results (van Zonneveld et al. 2012), since the two populations described in South America had the same pattern; 1) Ecuador and Northern Peru, 2) Southern Peru and Bolivia, with the third population being composed of new samples from Central America. Nevertheless, comparing this new data set, greater differences occur between Central and South America. 
All those results lead us to hypothesize that the most likely origin of $A$. cherimola is Mesoamerica (mainly Guatemala and Honduras) and probably Southern Mexico, although no samples from the latter area were available for this study. From this area, cultivation of cherimoya could have moved northwards to Mexico and southwards to Nicaragua and Costa Rica, using ecological corridors, and to South America, most likely carried by traders in Neolithic times. Cherimoya germplasm could have reached South America by sea (Wolters 2001) first in Northern Peru from where it was further dispersed north towards Ecuador and south towards Southern Peru. Andean cherimoya is characterized by high levels of phenotypic diversity already present in pre-Columbian times (Scheldeman et al. 2003). In contrast, low phenotypic diversity has been observed in Central America. Therefore Central America, where most of cherimoya genetic diversity can be found, could be the primary center of origin of cherimoya. From there, its cultivation was expanded to South America were phenotypic diversity increased probably due to human selection. The lower genetic diversity observed in the Andean region would be due to the bottleneck that took place before domestication in that area due to the absence of wild germplasm. A very similar situation to that shown in this work has been reported for Phaseolus vulgaris, the common bean, in which a Mesoamerican origin has also been proposed although most of the current improved varieties have an Andean origin (Bitocchi et al. 2012; 2013).

Since Northern Peru and Southern Ecuador were assumed to be the areas with the highest genetic diversity of cherimoya, most efforts to preserve cherimoya genetic resources both ex situ and in situ have been made following this hypothesis. Thus, the cherimoya germplasm collection of Spain, the largest in the world with more than 350 accessions, shows a clear overrepresentation of accessions from Peru, Ecuador and Bolivia compared to few accessions obtained from Central America. Interestingly, part of the Central American germplasm could have been indirectly preserved in the cherimoya material bred in California that probably included genetic material from Southern Mexico (Morton 1987). Regarding the future potential distribution of the crop, climate change models suggest that $A$. cherimola will be driven to higher altitudes sites. Most areas from Honduras and Guatemala, where the most diverse spots have been located, are predicted to be inadequate for cherimoya by the year 2,070 . Consequently, efforts to prioritize conservation of the endangered cherimoya genetic resources in its area of origin, both ex situ and in situ, should be encouraged before the extant diversity is lost.

The results obtained in this work strongly suggest a Mesoamerican origin of $A$. cherimola and a pre-Columbian movement of plant material (probably seeds) to South America resulting in a secondary center of diversity in the Andean region. Additional work in other fruit crops, such as avocado (Persea americana) which seems to be originated and 
domesticated in Central America but that was also present in South America in pre-Columbian times (Bost et al. 2013), could provide more information on the domestication, cultivation and germplasm exchange of native American fruit crops in pre-Columbian times. 


$$
80
$$




\title{
CROP EXCHANGE BEFORE 1492: CHERIMOYA REVEALS PRE-COLUMBIAN DISPERSAL ROUTES IN THE AMERICAS
}

\begin{abstract}
Dispersion routes of plant genetic resources are of great importance for conservation and genetic improvement programs, because it shapes their current diversity distribution. Many crops are known to have been domesticated in the Americas. Most have gone through a wide domestication process, ending in fixation of morphological traits and, hence, genetic differences distinguishing domesticated genotypes from their wild progenitors. On the other hand, tropical fruit tree crops are often not clearly genetically divergent from their progenitors because of low selection pressure, few cycles if any of genetic improvement, and low regeneration rates compared annual crops. This is especially the case within neglected and underutilized native fruit tree crops, several of which lost importance after 1492 with the introduction of new crops from other continents. In this scenario, one of those neglected and underutilized crop as Annona cherimola, seems to be a good model to explore the origin and cultivation of the species as well as provide better insight to crop movement by humans in pre-Columbian times. In this work, population and landscape genetic tools applied to a dataset of 1842 cherimoya accessions dataset amplified with microsatellite markers are used to infer the most likely dispersion routes of the crop from its center of origin in Central America. Results points out a direct connection among Southeastern Mexico and Northern Peru/Southern Ecuador.
\end{abstract}

\section{INTRODUCTION}

New archaeological, genetic and geographic techniques offer unprecedented possibilities in understanding processes of domestication and agricultural origins (Perry et al. 2007; Larson et al. 2014). Not only does this type of research provide further insights on our human history and capability of developing food systems but it also helps identifying hotspots of agrobiodiversity, which are source areas of valuable genetic resources to sustain current and future agrofood systems around the world. Contemporary geographic patterns of genetic diversity of any species are the result of past processes such as mutation, migration, genetic drift and natural and/or human selection. Thus, looking into the current molecular diversity the history of diversity distribution can be inferred. Genetic diversity analysis also provide support for the conservation of genetic crop resources, which are essential to select new material and design breeding programs in order to develop better varieties adapted to biotic and abiotic stresses. 
In the Americas, at least four centres of agriculture originated independently; Eastern North America, Mesoamerica, the Andean region and Tropical lowland South America (Pickersgill 2007; Larson et al. 2014). People from these centres were connected in preColumbian times, as evidenced by the exchange of several crops between North and South America including maize, beans, cocoa, and Capsicum peppers as well as metallurgy or pottery. Molecular studies for maize and bean show how these exchanges expanded domestication processes and increased crop diversity (Matsuoka et al. 2002; Vigouroux et al. 2008; Bittocchi et al. 2012, 2013). However, pre-Columbian crop and human dispersal routes remain poorly understood.

Fruit trees are an important part of traditional food systems in tropical America. Most fruit trees are often not clearly genetically divergent from their progenitors because of low selection pressure and low regeneration rates compared to annual crops. Some of the neglected and underutilized species (NUS) in the Americas which were more important for humans in the past could, in addition, provide some information about their incipiently domesticated or semi-domesticated state (Clement 1999) as well as their initial dispersion footprints. Because of their close genetic relationship with their ancestor populations, we propose here that neglected and underutilized fruit trees are a good model to explore agriculture origins and processes of crop domestication and dissemination in Tropical and Subtropical America.

Cherimoya ( $A$. cherimola Mill.) is one of those American NUS, a subtropical fruit tree grown from Mexico until Chile, probably in pre-Columbian times. In recent times, it has gained some commercial importance for fresh and processed fruit consumption in Spain and some Latin-American countries. In addition, diverse pharmacology properties have been discovered in this and other species of the Annonaceae (Liaw et al. 2011). The origin and domestication state of this species is still under discussion. It was generally believed that South America, and specifically the interandean valleys of Northern Peru and Southern Ecuador, was the center of origin of cherimoya due to the high phenotypic diversity that this species shows in this area or the presence of archaeological remains of seeds and ancient vessels resembling cherimoya fruits (Bonavia et al. 2004; Popenoe 1921). However, recent molecular studies (Larranaga et al. under revision, chapter 4) suggest that Central America is the region with the highest genetic diversity from where the species could have dispersed to South America. This hypothesis is also supported by a phylogenetic study of the section Atta of the Annonaceae (chapter 3), which places cherimoya in a Mexican-Mesoamerican clade of Annona species. Thus, an alternative hypothesis suggests a Mesoamerican center of origin for the species which has also been proposed previously by some authors (Pozorski and Pozorski 1997) and a pre-Columbian dispersion of the crop to South America. As most 
tropical fruit tree species, cherimoya is a predominantly outcrossing species pollinated by small beetles mainly of the Nitidulidae family (Gottsberger 1999). Natural seed dispersers, which could explain current distribution, have not been clearly characterized. Original dispersers that coevolved with cherimoya and other tropical fruit species like avocado or mombins (Persea americana Mill., Spondias purpurea L) could have belonged to the American megafauna that existed until the last Pliocene when they were extinguished. Since then, humans and, more recently, introduced horses and cattle could have been the main responsible agents for the dispersion of these species (Janzen \& Martin 1982; Barlow 2000).
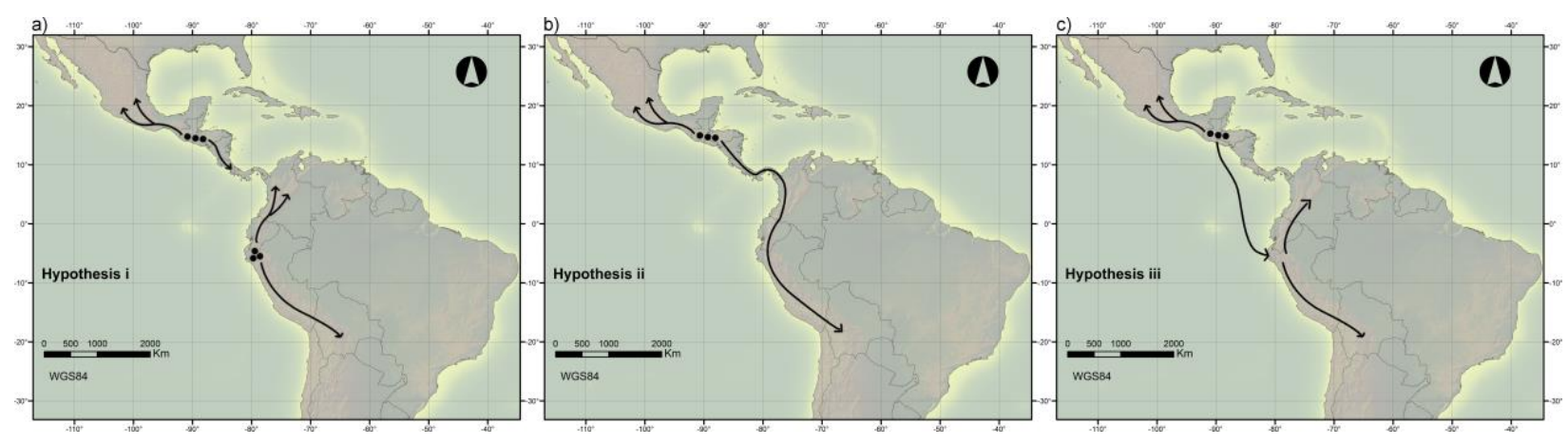

Figure 5.1. Hypothesis for the cherimoya dispersion.

The objective of this paper is to get further insights on Pre-Columbian crop exchange and dispersal routes in the Americas using cherimoya as a model species and apply concepts of population and landscape genetics to test three alternative hypotheses for its dispersion (Figure 5.1):

Hypothesis i) after the latest glacial period (approximately 110,000 to 12,000 years ago), cherimoya was dispersed from fragmented refugia of natural cherimoya populations in Central America and Northern Peru.

Hypothesis ii) cherimoya dispersed from its center of diversity located in Central America to the Andes after the latest glacial period by humans and/or other animals. Hypothesis iii) cherimoya was dispersed by sea traders in pre-Columbian times from Mesoamerica to the Andes.

To our knowledge, this study represents the most extensive molecular study of a new world fruit tree crop up to date with more than 1,800 georeferenced trees covering all the cherimoya range in the Americas from Mexico to Bolivia. Cherimoya diversity is mapped to identify diversity hotspots in its pre-Columbian distribution range. Second, population differentiation and allele's composition are analyzed. Third, it is presented a crop dispersal model to test several alternative dispersal routes from cherimoya's center of diversity. We 
then analyze how dispersal routes of cherimoya match with those of maize on the basis using the Panzea maize SSR dataset (www.panzea.org). Finally, it is discussed how the results provide insights to domestication processes and plant material exchange in Pre-Columbian America.

\section{MATERIALS AND METHODS}

\section{Plant material, DNA extraction and amplification}

An Annona cherimola microsatellite dataset, with 1765 different samples, used in Larranaga et al. (under revision, chapter 4) plus five amplified Colombian samples taken from the IHSMUMA-CSIC cherimoya germplasm bank and 72 samples obtained from two cherimoya collections in Mexico (CITACMEX in Estado de Mexico and a private garden centre in Michoacan) were used in this work. In all cases, geographic coordinates of the sampled trees were collected. Its distribution over 7 American countries is shown in Figure 5.2a. Extracted DNA from the total 1843 geo-referenced cherimoya trees was amplified using 9 microsatellites loci chosen due to their widely dispersion along the cherimoya genome and their very high polymorphism (Larranaga et al. under revision, chapter 4; van Zonneveld et al. 2012): LMCH1 (CT as the unit repetition unit), LMCH4 (GA), LMCH16 (GA), LMCH48 (GA), LMCH69 (GA and GT), LMCH87 (GA), LMCH122 (GA), LMCH139 (CT), LMCH144 (CT) (Escribano et al. 2004, 2008). Fragment sizes were determined using a Beckman Coulter Genome LabTM GeXP capillary DNA analysis system. For further details of sampling, DNA extraction and amplification see Larranaga et al. (under revision, chapter 4). Every map figure was constructed in ArcMap 10.1. Layer with country boundaries was downloaded from the DIVA GIS web page and layer 1:10 Cross-blended Hypsometric Tints from Natural Earth. In order to test the simplest scenarios obtained in this work in other species, all samples obtained from North, Central and South America, and which were previously used by Vigouroux et al. (2008) were selected from the Panzea SSR maize dataset (panzea.org). Their distribution is shown in Figure 5.2b.

\section{Geographic patterns of diversity}

Maps based on spatial diversity indexes [allelic richness (AR) and expected heterozygosity $(\mathrm{HE})$ ] were obtained following Larranaga et al. (under revision, chapter 4), Thomas et al. (2012a) and van Zonneveld et al. (2012) for the whole cherimoya data set. The applied Circular Neighborhood had 60 minutes of diameter and all grids of 10 min side size with more than 7 trees were taken into account to obtain the different diversity indexes. 

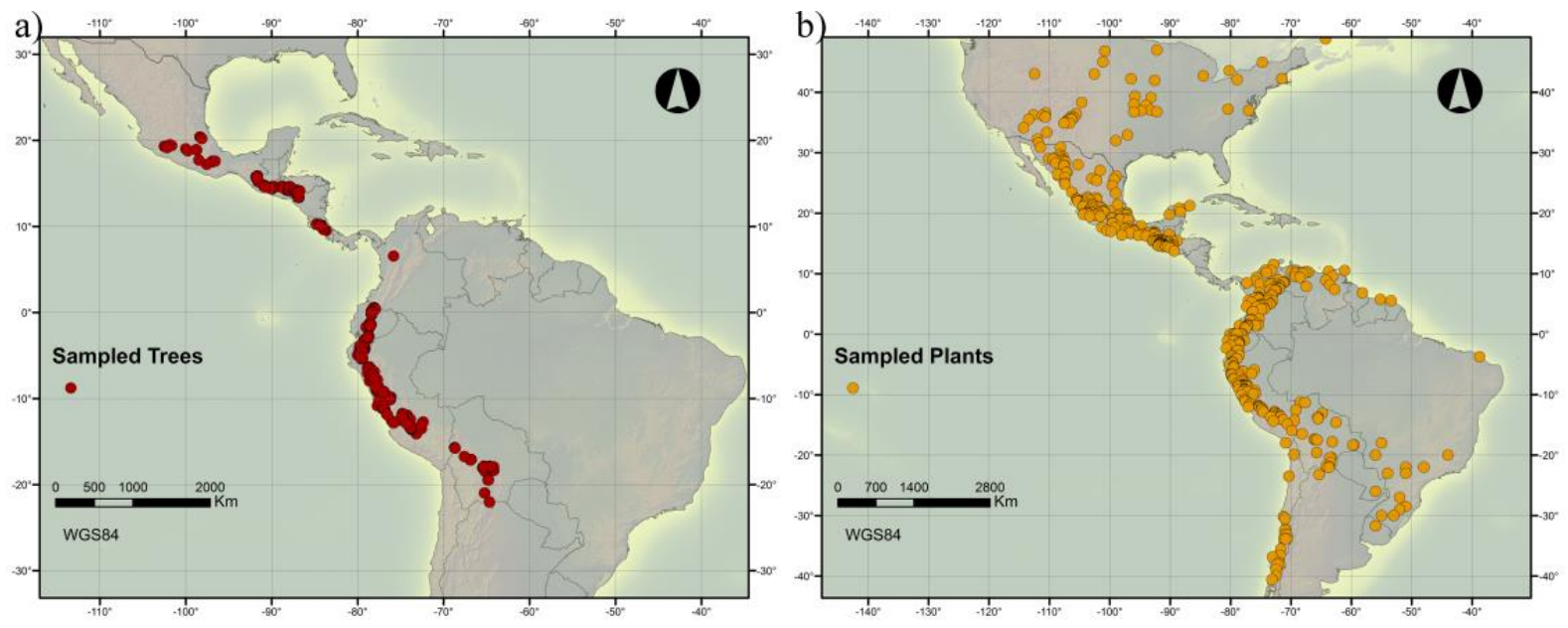

Figure 5.2. Geolocalization of cherimoya (a) and maize (b) accession data set.

\section{Population differentiation and allele analysis}

Although population distribution generally does not fit with geopolitical boundaries, here, to test the structure of the cherimoya data, samples from 9 countries were divided in two groups. Group 1 was composed by samples from the four Central American countries studied: Mexico, Guatemala, Honduras and Costa Rica. Group 2 included samples from Colombia, Ecuador, Northern Peru (NPeru), Southern Peru (SPeru) and Bolivia. Distribution of genetic diversity was inferred by the analysis of molecular variance (AMOVA) based on the number of different alleles using the ARLEQUIN software version 3.5.2.2 (Excoffier et al. 2005) and 1000 permutations. Pairwise Fst (Weir and Cockerham 1984) and Rst derived from (Michalakis \& Excoffier 1996) $(p<0.05)$ matrixes for the analysis of differentiation between defined populations were calculated using the same software and 1000 permutations. Fst values can be indicative of current gene flow between populations or the recentancient common ancestry (Schwartz et al. 2002).

Number of alleles and number of private alleles per country were calculated with and without rarefaction with Arlequin software version 3.5.2.2 and ADZE (Szpiech et al. 2008). For rarefaction, the maximum standardized sample size was set to twice the number of samples of Guatemala while Colombian samples were not taken into account due to the small number of samples available.

\section{Dispersal pathways of cherimoya from its center of origin}

Least-cost distances among randomly selected $50 \%$ of the 10 min cell mid points that include 4 or more trees (median of the trees distribution among cells), were calculated. These geographic distance matrixes were obtained based on several heterogeneous geographic 
spaces (transition layers) represented as grids of $10 \mathrm{~min}$ sides storing the data about the probability or cost of transitioning from one cell to another (van Etten 2011) (Table 5.1). In addition, two approaches implemented in the packages adegenet and mmod of $\mathrm{R}$ to obtain the Nei's pairwise Fst (1973) pairwise distances were employed among all mid-point cells selected. Correlation between the geographic and genetic distance matrixes was calculated by a Mantel test. The process was repeated 100 times. Averaged correlation, standard deviation and averaged pvalues of the 100 replicates were recorded. In addition, correlation with an Euclidian distance matrix (Crow) was also calculated. Average correlation values were compared by ANOVA and Tukey analysis. All calculations were performed in R using the following packages; gdistance (van Etten 2015), adegenet (Jombart 2008; Jombart \& Ahmed 2011), dismo (Hijmans et al. 2011), raster (Hijmans \& van Etten 2015), ncf (Bjornstad 2013) and mmod (Winter 2012).

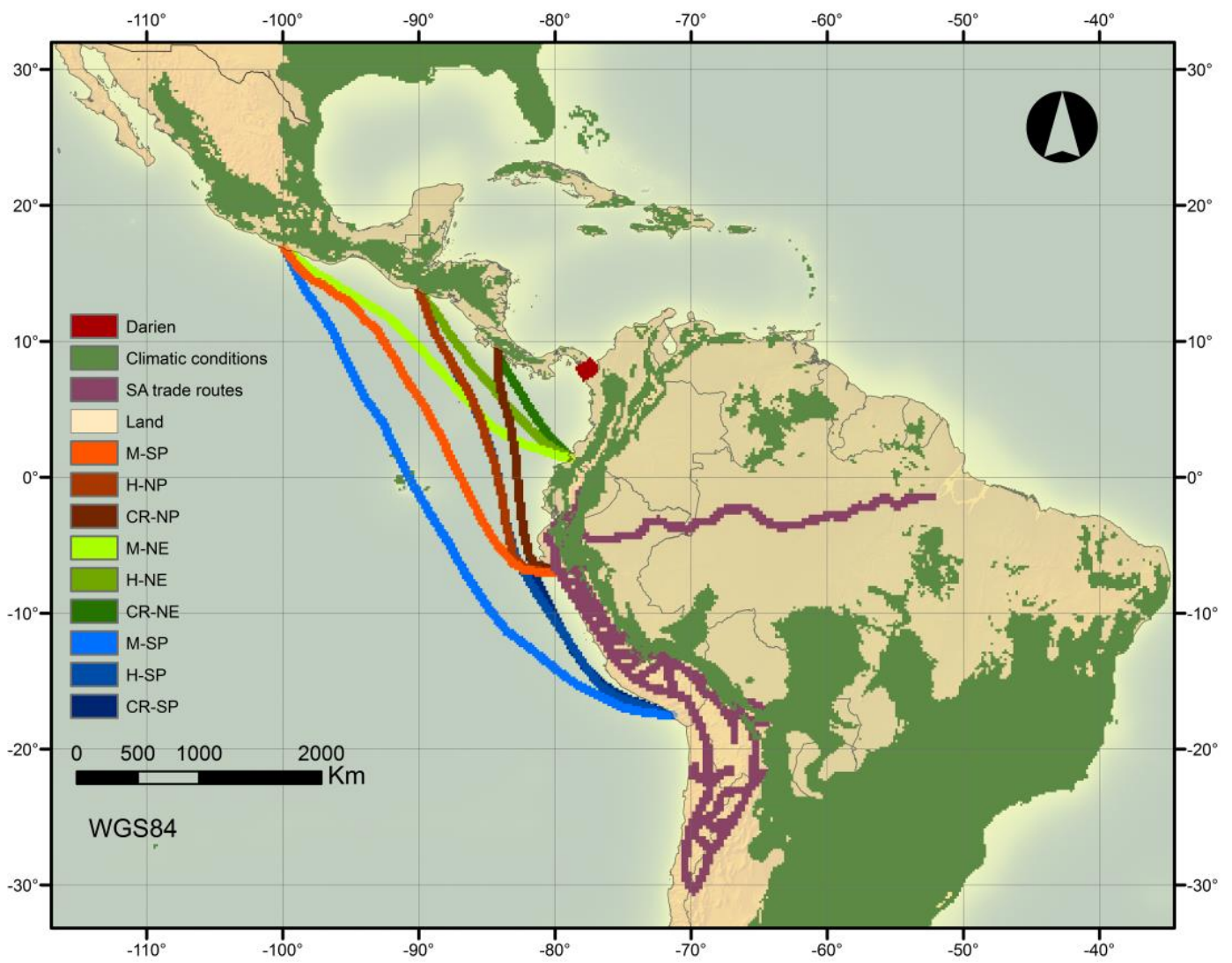

Figure 5.3. Variables taken into account for the construction of the different transition layers. 
Table 5.1. Variables and conductance values of the transition layers constructed.

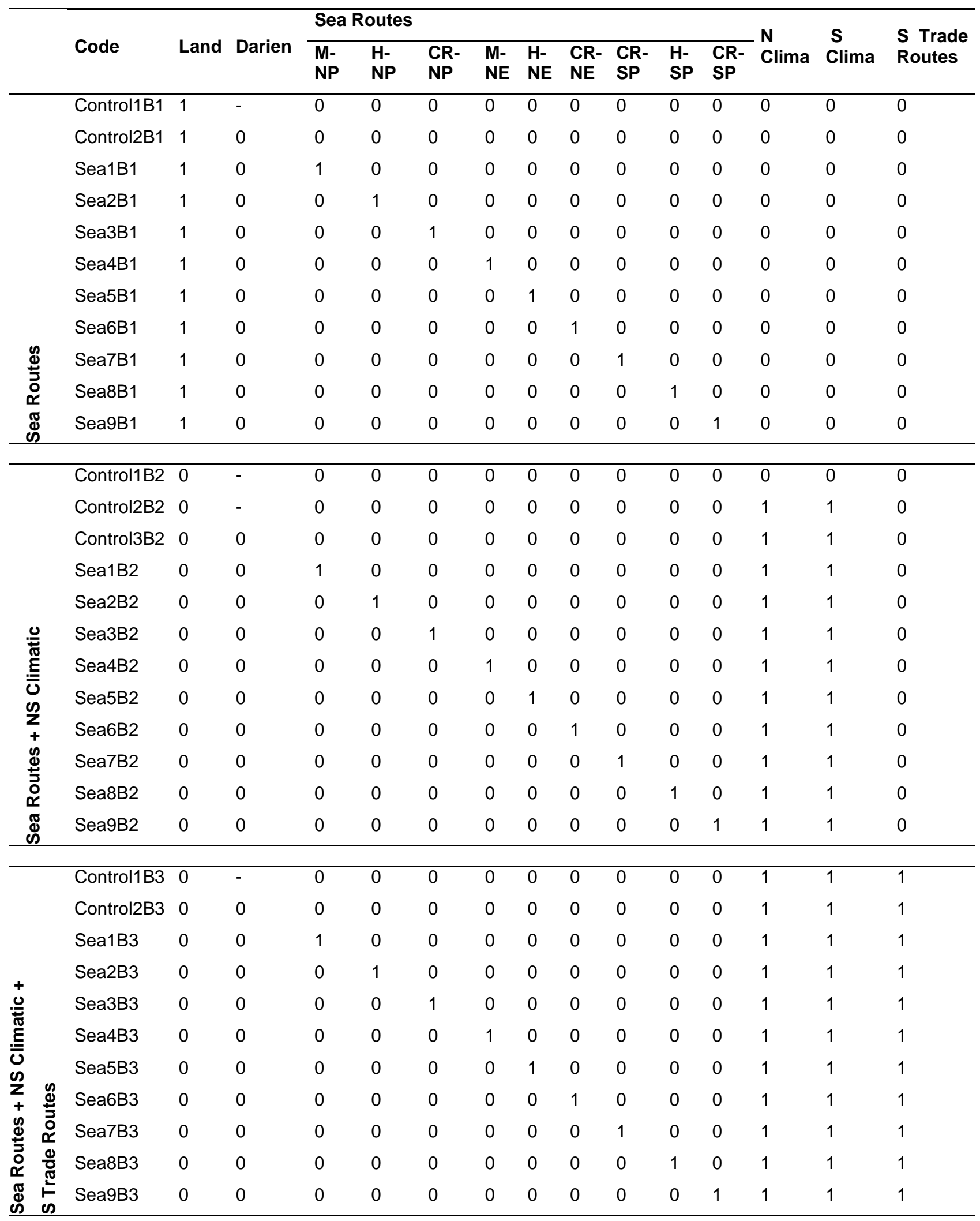




\begin{tabular}{|c|c|c|c|c|c|c|c|c|c|c|c|c|c|c|c|}
\hline \multirow{11}{*}{ 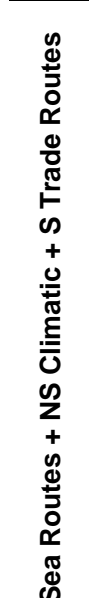 } & Control1B4 & 0 & - & 0 & 0 & 0 & 0 & 0 & 0 & 0 & 0 & 0 & 1 & 0 & 1 \\
\hline & Control2B4 & 0 & 0 & 0 & 0 & 0 & 0 & 0 & 0 & 0 & 0 & 0 & 1 & 0 & 1 \\
\hline & Sea1B4 & 0 & 0 & 1 & 0 & 0 & 0 & 0 & 0 & 0 & 0 & 0 & 1 & 0 & 1 \\
\hline & Sea2B4 & 0 & 0 & 0 & 1 & 0 & 0 & 0 & 0 & 0 & 0 & 0 & 1 & 0 & 1 \\
\hline & Sea3B4 & 0 & 0 & 0 & 0 & 1 & 0 & 0 & 0 & 0 & 0 & 0 & 1 & 0 & 1 \\
\hline & Sea4B4 & 0 & 0 & 0 & 0 & 0 & 1 & 0 & 0 & 0 & 0 & 0 & 1 & 0 & 1 \\
\hline & Sea5B4 & 0 & 0 & 0 & 0 & 0 & 0 & 1 & 0 & 0 & 0 & 0 & 1 & 0 & 1 \\
\hline & Sea6B4 & 0 & 0 & 0 & 0 & 0 & 0 & 0 & 1 & 0 & 0 & 0 & 1 & 0 & 1 \\
\hline & Sea7B4 & 0 & 0 & 0 & 0 & 0 & 0 & 0 & 0 & 1 & 0 & 0 & 1 & 0 & 1 \\
\hline & Sea8B4 & 0 & 0 & 0 & 0 & 0 & 0 & 0 & 0 & 0 & 1 & 0 & 1 & 0 & 1 \\
\hline & Sea9B4 & 0 & 0 & 0 & 0 & 0 & 0 & 0 & 0 & 0 & 0 & 1 & 1 & 1 & 1 \\
\hline
\end{tabular}

Transition layers scenarios constructed in ArcGis 10.1 are described in Table 5.1. Cell values (probability or cost of transitioning from one cell to another) were 0 (non-conductance), 1 (normal conductance) and 0.00001 (low conductance). To create the transition layer scenarios several spatial variables were converted to raster with the same cell size (10min) and aligned one to another: a) A map of America downloaded from the DIVA GIS web page, merged in one polygon; b) a polygon in the South of Panama resembling the Darien forest (a tropical forest and swamps sparsely populated that is the physiographic link between Central and South America) was traced manually; c) 9 different hypothetical sea routes connecting Western Mexico $(M)$, Northern Honduras in the border with Guatemala $(H)$ and Western Costa Rica (CR) with Northwestern Ecuador (NE), Northern Peru (NP) and Southern Peru (SP) were manually traced and converted to raster after given a buffer of $20 \mathrm{~min}$; d) proper climatic conditions for A. cherimola were taken from Bydekerke et al. (1999) and Rosell et al. (1997) (13-25 ${ }^{\circ} \mathrm{C}$ annual temperature and more than $600 \mathrm{~mm}$ of precipitation). Bioclimatic layers (1 and 12) were downloaded from World Clim (www.worldclim.org/download) and places where conditions were met selected; e) Pre-Columbian trading routes in South America were manually mapped from Carballo (2012) with a buffer of 20min. Each combination of transition layers was created with the tool mosaic to new raster and converted to asc file (.txt).

\section{Comparison of cherimoya and maize dispersal routes}

Maize data set was only tested with scenarios of the first block (Table 5.1; block 1 developed to test the effect of 9 different sea routes) as all the rest included cherimoya bioclimatic conditions. Since original data are more dispersed and less samples were available, leastcost distances among randomly selected $50 \%$ of the 20 min cell mid points that include 3 or more trees (third quartile of the trees distribution among cells), were calculated. 


\section{RESULTS}

\section{Geographic patterns of cherimoya diversity}

The highest levels of allelic richness (AR) and expected heterozygosity (EH) corrected by sampling bias were observed in Central America, more specifically Honduras, and declined in the surrounding areas in Costa Rica and Mexico and were further reduced in South America (Figure 5.4, Table 5.2). The lowest values were found in the southernmost margins of the study range in Bolivia as well as in the five Colombian samples.

Table 5.2. Allelic Richness and Expected Heterozygosity values per country.

\begin{tabular}{|c|c|c|c|c|c|}
\hline & \multirow{2}{*}{$\begin{array}{l}\text { № } \\
\text { Grids }\end{array}$} & \multicolumn{2}{|c|}{$\begin{array}{l}\text { Allelic } \\
\text { Richness }\end{array}$} & \multicolumn{2}{|c|}{$\begin{array}{l}\text { Expected } \\
\text { Heterozygosity }\end{array}$} \\
\hline & & Average & SD & Average & SD \\
\hline Mexico & 151 & 3.94 & 0.7 & 0.63 & 0.04 \\
\hline Guatemala & 69 & 6.14 & 0.36 & 0.75 & 0.02 \\
\hline Honduras & 98 & 6.14 & 1.13 & 0.73 & 1.13 \\
\hline Costa Rica & 51 & 3.92 & 0.16 & 0.64 & 0.01 \\
\hline Colombia & 2 & 2.8 & 0.15 & 0.48 & 0 \\
\hline Ecuador & 203 & 3.1 & 0.19 & 0.5 & 0.03 \\
\hline Perú & 537 & 3.34 & 0.39 & 0.54 & 0.06 \\
\hline Bolivia & 227 & 2.61 & 0.13 & 0.44 & 0.04 \\
\hline
\end{tabular}

Of a total of 177 alleles, 175 are present in Central America and Mexico, while 67 are present in South America. Mexico showed 33\% of the total of alleles, Guatemala $60 \%$, Honduras 90\%, Costa Rica 28\%, Colombia just 9\%, and Ecuador, NPeru, SPeru and Bolivia $32 \%, 30 \%, 32 \%$ and $22 \%$, respectively. Thus, Central America and Mexico showed 110 alleles not present in South America and just 2 in the other way around. By country, Mexico had 1 unique allele, Guatemala 13, Honduras 48 and SPeru 1 while the rest is present in more than one of the populations. Rarefacted allelic richness and private allelic richness is shown in Figure 5.5. In both cases Honduras and Guatemala show the highest levels, which do not decrease with increasing number of sampled alleles.

\section{Population differentiation and gene flow}

AMOVA results on population differentiation indicate that more diversity is explained between Central and South American groups than among the different countries within each group (Table 5.3). The pairwise Fst and Rst matrixes are represented in Figure 5.6 a and b. All pvalues showed significant differences $(p<0.05)$. Values are higher for Rst but relative 
differences between populations are almost the same. Comparisons within groups of countries showed relatively low values meaning that gene flow is/was common among them. Between groups, the lowest values were obtained when comparing Northern and Southern Peru with all Central American countries including Mexico and the highest values were obtained when comparing Honduras or Costa Rica with Bolivia and Colombia.
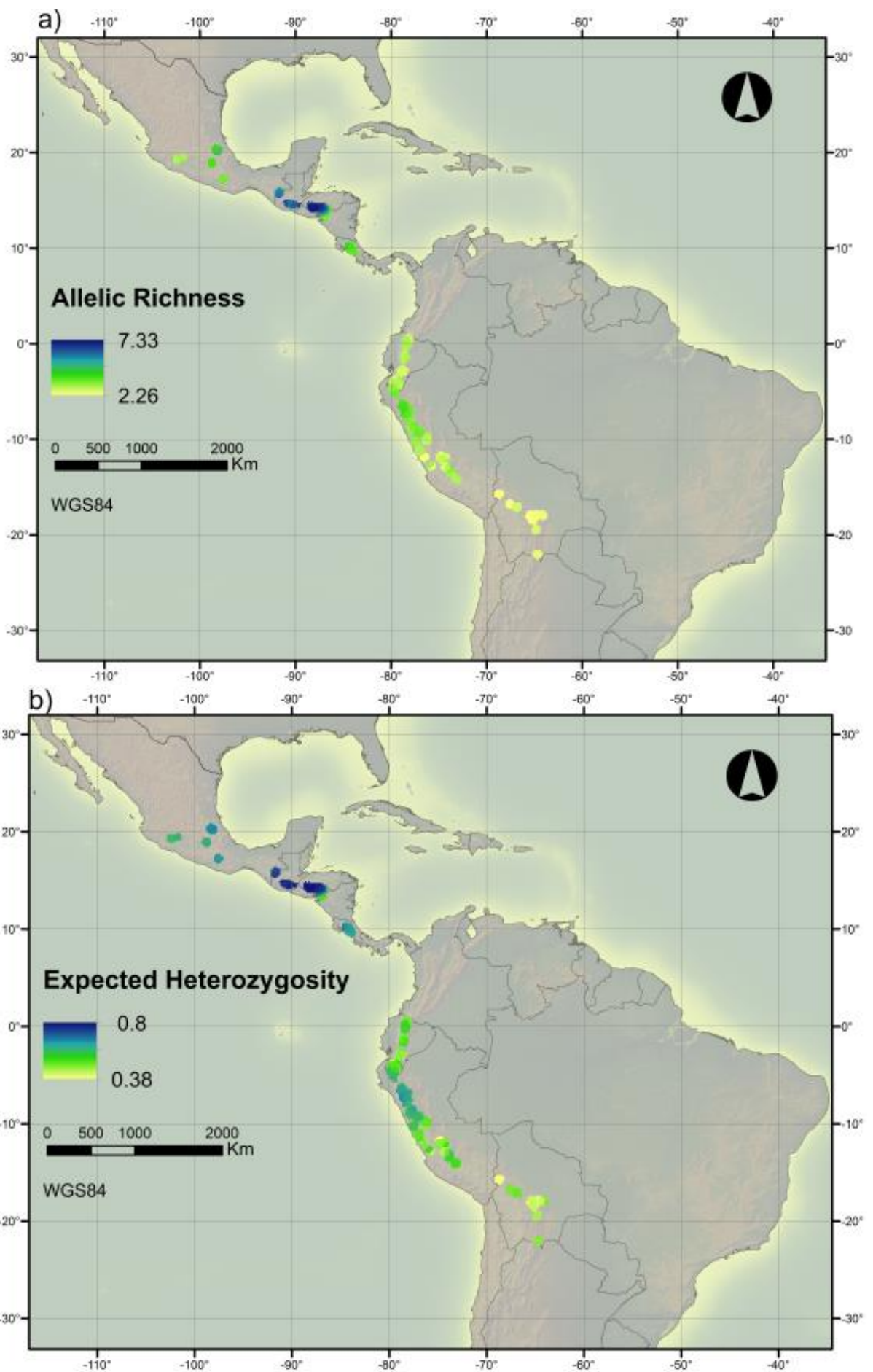

Figure 5.4. Spatially obtained allelic richness (a) and expected heterozygosity (b). 


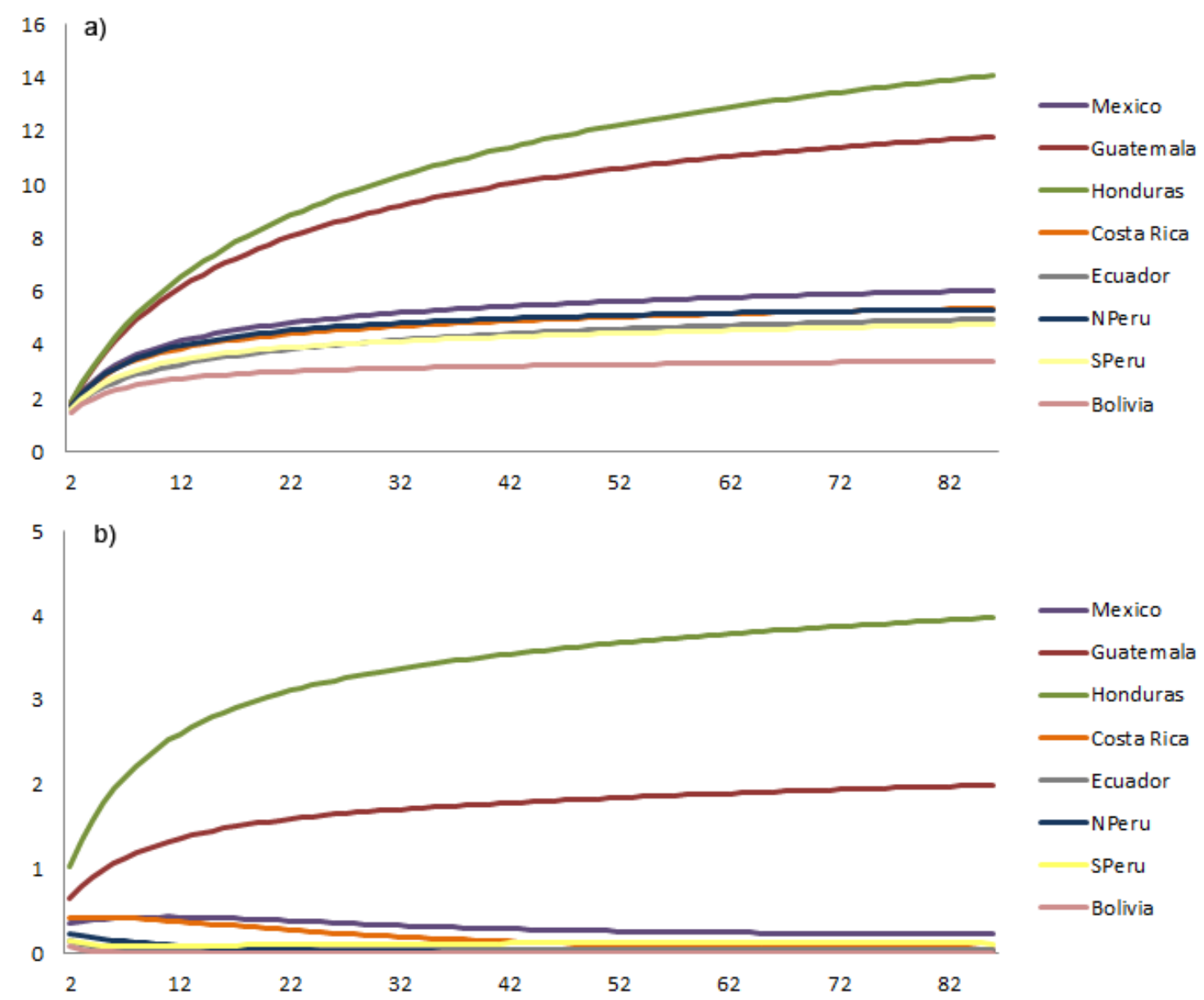

Figure 5.5. Allelic richness (a) and private allelic richness (b) with rarefaction obtain within each country accessions. Maximum sample size (86) corresponded to double the smallest population size (Guatemala=43).

Table 5.3. AMOVA results

\begin{tabular}{|c|c|c|c|c|c|c|}
\hline $\begin{array}{l}\text { Source of } \\
\text { Variation }\end{array}$ & d.f. & $\begin{array}{l}\text { Sum of } \\
\text { Squares }\end{array}$ & $\begin{array}{l}\text { Variance } \\
\text { Components }\end{array}$ & $\begin{array}{l}\text { Percentage } \\
\text { of } \\
\text { Variation }\end{array}$ & $\begin{array}{l}\text { F } \\
\text { Statistics }\end{array}$ & p-value \\
\hline $\begin{array}{l}\text { Among } \\
\text { Groups }\end{array}$ & 1 & 510.489 & 0.3832 & 11.03 & 0.19633 & $<0.001$ \\
\hline $\begin{array}{l}\text { Among } \\
\text { Populations } \\
\text { within } \\
\text { Groups }\end{array}$ & 7 & 838.756 & 0.29918 & 8.61 & 0.09675 & $<0.001$ \\
\hline $\begin{array}{l}\text { Within } \\
\text { Populations }\end{array}$ & 3675 & 10265.04 & 2.79321 & 80.37 & 0.11025 & $<0.05$ \\
\hline Total & 3683 & 11614.29 & 3.47558 & & & \\
\hline
\end{tabular}




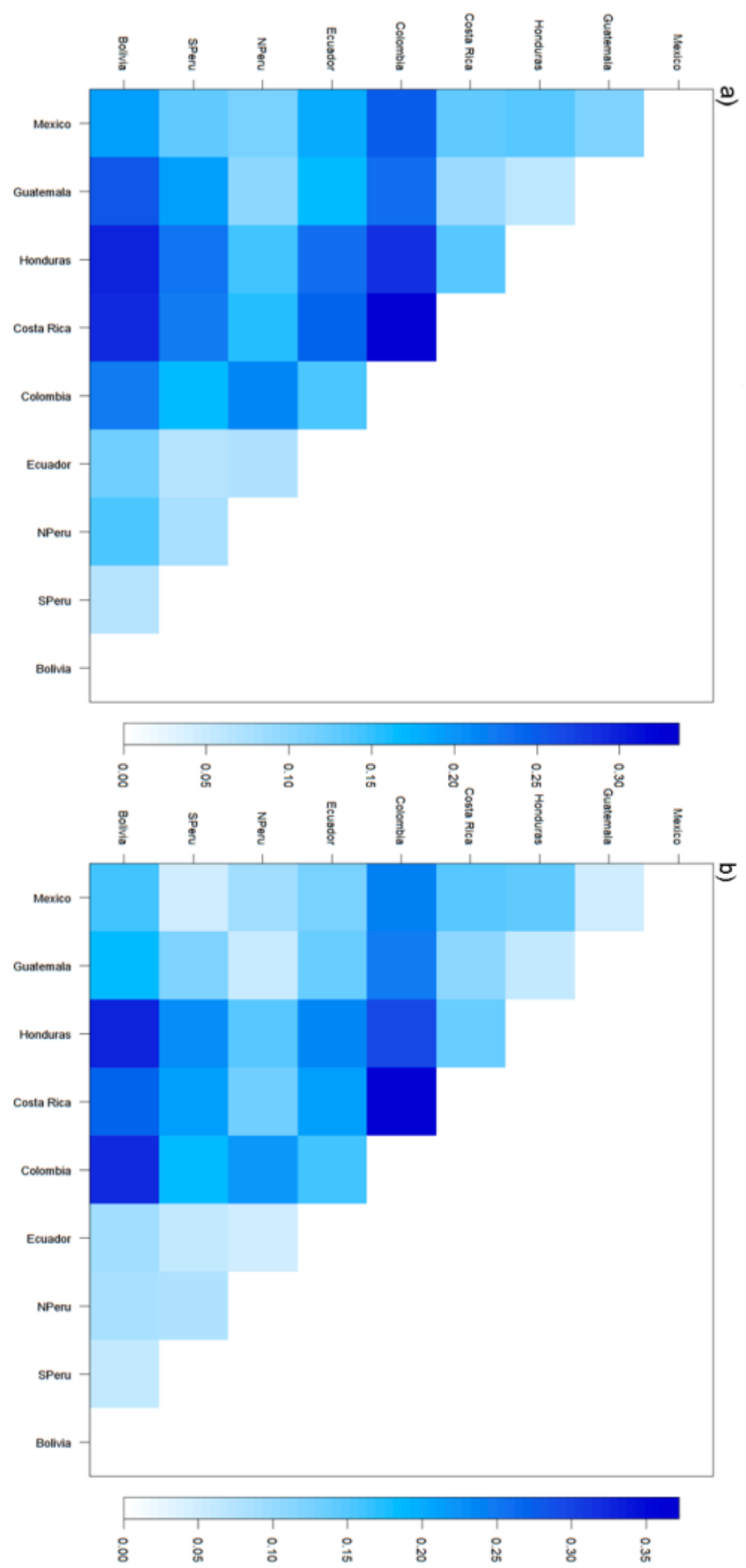

Figure 5.6. Pair-wise Fst (a) and Rst (b) among each country accessions. 


\section{Cherimoya dispersal pathways}

Isolation by distance models to test different alternative dispersal routes of cherimoya from its Central American origin were developed (Fig. 3). The models differ in their geographic distances, least cost distances with specific transition matrixes for each dispersal scenario (see method). Mantel test analyses were used to correlate the geographic distances of each scenario with the genetic distances (Fst implemented in two R packages) in order to identify the dispersal model that could best explain the contemporary patterns of cherimoya genetic variation (Figure 5.7). Averaged $p$ values of the Mantel test for 100 repetitions were significant $(<0.05)$ in almost all cases. One way ANOVA indicated that some of the means were significantly different ( $p$ value $<0.05$ ) in each set of correlations and the Tukey test permitted to compared all pairs of means.

Four different blocks of scenarios were tested taking into account different variables that could shape current $A$. cherimola distribution (Table 5.1). Controls of each block (Control1B1, Control1B2, Control1B3, Control1B4) showed similar values with Crow (distance as the crow flies; euclidean distance). Significant differences with controls were considered positive when shown by both sets of correlations (adegenet and mmod):

\section{Block 1 (Sea Routes)}

Developed to test the effect of 9 different sea routes. Conductance values in land cells, except Darien forest, and traced sea routes were 1. Control1B1 and Control2B1 were constructed as controls. Scenarios Sea1B1, Sea2B1, Sea4B1, Sea5B1, Sea7B1 and Sea8B1, routes that connected Mexico or Honduras with South America, showed significantly higher values when compared to Control1B1, same scenario without sea routes or Darien forest. Sea1B1 and Sea4B1, routes that connected Mexico with NPeru or NEcuador, respectively, showed the highest values.

\section{Block 2 (Sea Routes + NS Climatic)}

Developed to test the effect of 9 different sea routes together with proper climatic conditions for A. cherimola. Conductance values in land cells (except Darien forest), were almost 0 , (0.00001), to avoid as much as possible but not completely transition among cells, while proper climatic condition areas and traced sea routes were 1. Control1B2, Control2B2 and Control3B2 were constructed as controls. Scenarios Sea1B2 to Sea6B2 tested showed significantly lower differences with Control1B2, scenario with same surface probabilities of movement without sea routes, Darien forest or proper climatic conditions. Routes connecting any Central or North American country with SPeru showed no significant differences. 


\section{Block 3 (Sea Routes + NS Climatic + S Trade Routes)}

Developed to test the effect of 9 different sea routes, proper climatic conditions for $A$. cherimola in the whole continent, and land trade routes in pre-Columbian South America. Conductance values in land cells, except the Darien forest, were almost $0,0.00001$, to avoid as much as possible but not completely transition among cells, while proper climatic condition areas, land SA pre-Columbian trade routes and traced sea routes were 1. Control1B3 and Control2B3 were constructed as controls. Scenarios Sea1B3 and Sea4B3 (routes that connected Mexico with NPeru or NEcuador, respectively) showed significantly higher values compared to Control1B3, same scenario without sea routes or Darien forest.

\section{Block 4: (Sea Routes + N Climatic + S Trade Routes)}

Developed to test the effect of 9 different sea routes, proper climatic conditions for cherimoya north of the Darien forest, and land trade routes in pre-Columbian South America. Conductance values in land cells, except the Darien forest, were almost 0, 0.00001, to avoid as much as possible but not completely transition among cells, while proper climatic condition areas Northern Darien, land SA pre-Columbian trade routes and traced sea routes were 1. Control1B4 and Control2B4 were constructed as controls. All results in this block were significantly lower compared to the control.

\section{Comparison between maize and cherimoya dispersal routes}

In the case of maize, just the first block of scenarios was tested and the results obtained are shown in Figure 5.8. Similarly to cherimoya, averaged $p$ values of the Mantel test for 100 repetitions were significant $(<0.05)$ in all cases. The one way ANOVA indicated that some of the means were significantly different ( $p$ value $<0.05$ ) in both sets of correlations and the Tukey test permitted to compared all pair of means. Control1B1 showed similar values with Crow. All correlation values were lower than the control1B1, showing significant differences except the routes that connected Central America with Northern Ecuador. 


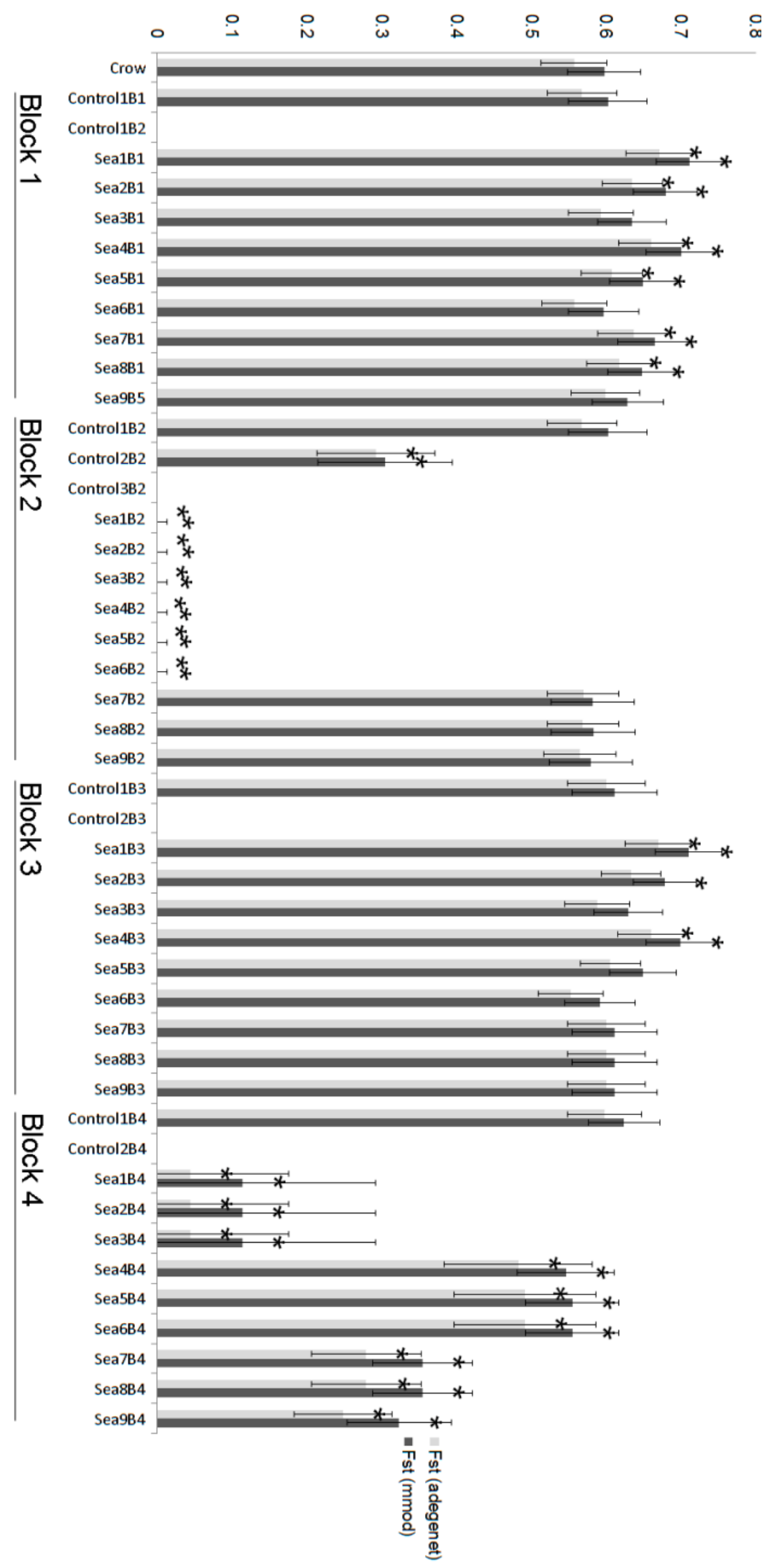

Figure 5.7. In the $X$ axis each scenario is represented. $Y$ axis corresponds to averaged Mantel correlation values and its standard deviation between genetic (Fst implemented in two $R$ packages) and geographic distances (least cost distances under different scenarios) of the cherimoya dataset among 100 repetitions that took randomly $50 \%$ of the data that was included in 10 min grids with more than the mean of its distribution among all of them. 


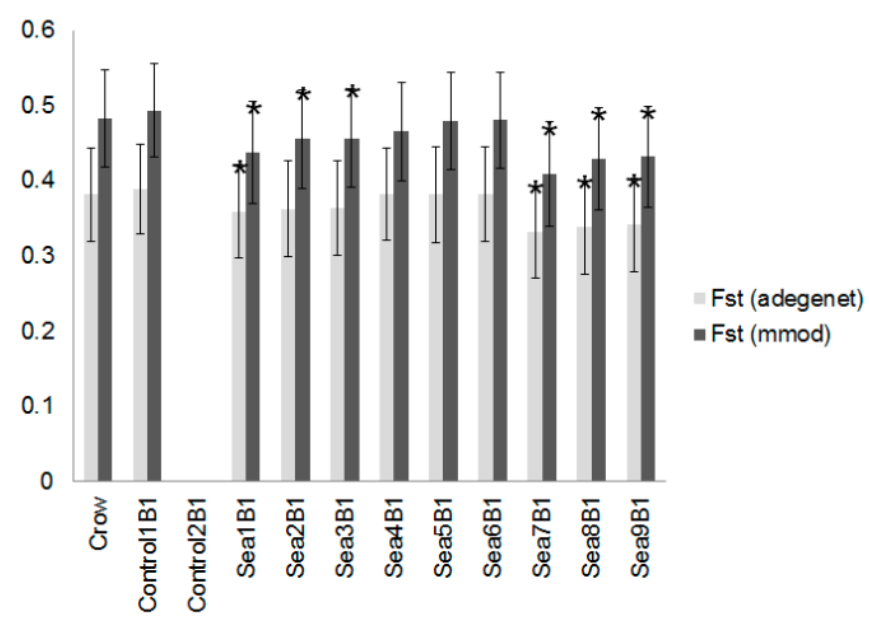

Block 1

Figure 5.8. In the $X$ axis each scenario is represented. $Y$ axis corresponds to averaged Mantel correlation values and its standard deviation between genetic (Fst implemented in two $R$ packages) and geographic distances (least cost distances under different scenarios) of the maize dataset among 100 repetitions that took randomly $50 \%$ of the data that was included in 20 min grids with more than the third quartile of its distribution among all of them.

\section{DISCUSSION}

The first hypothesis for the cherimoya dispersion that assumes that the species was dispersed from fragmented refugia of natural cherimoya populations in Central America and Northern Peru, could be rejected when looking into the shared and private alleles distribution. Only two private alleles were found exclusively in South America while 110 where encountered in Central American samples. This supports that cherimoya reached South America from Central America, maybe through a few individuals, carrying most of the alleles currently present in the area. Two of the previously 4 private alleles found in South America (Larranaga et al. under revision, chapter 4) were found in this work to be present in Mexico further reducing the number of private alleles found in South American samples. If cherimoya was dispersed over the continent before the last glacial period, which initiated around 110,000 years ago, and stayed in refuges both in Central America and Northern Peru, more unique alleles would be predictable within the South American samples. Microsatellite mutation rate is often quoted in the range of $10^{-3}$ to $10^{-4}$ per locus per generation (Ellegren 2000; Guichoux et al. 2011), which means one mutation per 100 to 1,000 generations. Since one generation of $A$. cherimola lasts a minimum of 4-5 years, we could expect that in the last 110,000 years, 275 to 27.5 mutation events would have taken place per locus. Allele sizes already existing in one population could emerge again after one mutation event being similar 
by state but not by descend (homoplasy). Nevertheless just two private alleles have been found in South America (NPeru and SPeru) in different loci and, if the step mutation model (SMM) is assumed, alleles of similar sizes would be expected to have emerged over this period of time and we would not expect big gaps in the alleles size distribution

The second hypothesis that humans, rodents or other biotic agents dispersed cherimoya across the continent after the last glacial period from Central America to South America, can be also rejected looking into the allelic richness, expected heterozygosity, and Fst/Rst (by country) distribution. Between both continents diversity values does not follow a continuous decrease from the center of diversity as would be expected if cherimoya was planted or eaten and germinated along the way. However, within each continent this premise is met. The addition of 72 samples obtained in Central Mexico did not change previous reported results where higher values of allelic richness or expected heterozygosity were located in Mesoamerican countries (Honduras and Guatemala) followed by the rest of locations in Central America, Mexico and North Peru (Larranaga et al. under revision, chapter 4). The high standard deviation obtained in Honduras seems to be due to the lower values recorded in the Nicaraguan border, corresponding to samples isolated from the rest in a mountain range separated by lowlands. Same happens with pairwise Fst/Rst values. The fixation index (Fst) has been widely used as a population differentiation estimator but its value is highly dependent on the level of diversity within subpopulations (Hs). Thus, Fst becomes very small when Hs is large, which could be the case here. Many Fst analogs have been described since; among them Gst, $\varphi s t$, Rst or D. Rst was developed for microsatellites under the step mutation model (SMM). It does not depend on Hs but when SMM is not always met, this estimator could not be reliable. In addition it does not perform better that Fst when the timescale of interest is short and the influence of mutation is then relatively small (Meirmans \& Hedrick 2011; Slatkin 1995). All the alleles studied did meet the SMM since different sizes among them are pair numbers, with the exception of the allele 157 of the marker LMCH169. Among each group: Mexico, Guatemala, Honduras and Costa Rica samples, or Ecuador, NPeru, SPeru and Bolivia values were generally low, and even lower among pairs of countries geographically closer, pointing to a gene flow connected zone where migration (dispersion) could have occur in a linear manner. On the other hand, between groups, less differentiated zones (or sharing the most recent common ancestry) seem to be Northern and Southern Peru with all Central American countries including Mexico and the opposite among Honduras or Costa Rica with Bolivia and Colombia. Colombian results must be taken carefully since just 5 samples were available.

Thus, a model to test the last hypothesis "Cherimoya was dispersed by sea traders in pre-Columbian times from Mesoamerica to the Andes", was constructed based on landscape 
genetics tools. The main goal of this approach (Manel et al. 2003, Manel \& Holderegger 2013), is to combine the high resolution obtained from molecular information with spatial data and a variety of statistical methods to evaluate the role that landscape variables play in shaping genetic diversity and population structure (Storfer et al. 2007). Thus, landscape genetics integrates more landscape characteristics than beeline distance to give a more realistic estimate of the effective distance between demes (Holderegger \& Wagner 2006). Four different blocks of different scenarios were tested, taking into account different variables that could shape current $A$. cherimola distribution. The isolation-by-distance models (Wright 1943), which best explained the genetic variation indicate that cherimoya travelled from Mexico to Northern Peru after suffering an important bottleneck. From there it dispersed northwards and southwards along the interandean valleys. These results are in concordance with previous observation of allelic richness, expected heterozygosity and allele frequency distribution as well as Fst/Rst observed values among countries samples. Wolters (2001) hypothesized the existence of trade routes among Mesoamerica and South America (Ecuador/Peru) on the basis of resemblance archeological pottery, metallurgy, linguistic or sea vessels evidences. Thanks to these trade routes many other crops could have also been exchanged between both areas; those include for example peanut (Arachis hypogaea), manioc (Manihot esculenta), cacao (Theobroma cacao) or tobacco (Nicotiana tabacum) from South to North or avocado (Persea americana), pepper (Capsicum annuum), grain amaranthus (Amaranthus spp.), chayote (Sechium edule) or jimsonweed (Datura stramonium) the other way round. Here it is provided evidence that the latter was also the case for cherimoya. Actually, Bitocchi et al. (2012; 2013) reported a Mexican origin of the common bean (Phaseolus vulgaris) and a bottleneck that dramatically reduced the diversity of the Andean genepool compared to the Mesoamerican one before two independent domestication processes took place. In addition, certain populations in the North of PeruEcuador remained genetically closer to some Mexican samples suggesting a migration in ancient times.

Our results also suggest that after cherimoya's arrival in Northern Peru, climatic conditions and trade routes in South America had an important role in the dissemination of this crop along the South American continent. These results could explain the presence of trees collected in areas with no proper climatic conditions for growing this crop but located close to the ancient South American trade routes. The Inca road network adapted to this model from Carballo (2012) represents the final pre-Columbian manifestation of imperial trading systems.

In the case of maize a dispersion mediated by pre-Columbian traders along sea routes does not seem probable. Scenarios taking into account sea routes showed lower correlation 
values when compared with its control (land movement). This species, known to have been domesticated in Mesoamerica between 9 and 10 thousands of years ago (Matsuoka et al. 2002; Pickersgill 2007; Larson et al. 2014), could have been dispersed and exchange by land in very early times and accompanied the foundation of great civilizations probably before the establishment of sea routes.

In short, Annona cherimola could have emerged as species in Central America from where it would have been dispersed to central Mexico and Costa Rica along natural corridors probably before the last glacial period when still American megafauna existed. In this area, high genetic diversity is encountered although there is little evidence of phenotypic diversity and varietal differentiation. It would have started to be cultivated by humans and from Southern Mexico a few seeds (probably in different trips) would have been carried to South America (Ecuador/Peru) where cultivation continued thanks to the existence of proper climatic conditions and advanced agricultural systems. As a result, high phenotypic variation appeared (Scheldeman et al. 2003), although the genetic variation decreased considerably; showing the characteristics of a (semi) domestication paradox. From there it could have been carried by humans to Colombia or along the Andes to Bolivia where the heterogeneity of the landscape and the terrace agrosystem developed by pre-incaic cultures permitted to reach warm temperatures to grow this and other horticultural and fruit tree crops at high altitudes (National Research Council Panel on Lost Crops of the Incas 1990). A similar situation could also be shared by other American crops and, thus, this initial model could also help to understand their dissemination along the continent and cultural exchange among the existing strong civilizations before the Spanish conquest. Additional work to tune up the model would include analyzing additional proper climatic conditions, change the number of trees per cells, include other or more defined routes or the possibility of doing a resampling with the raw data. 


$$
\therefore: 0
$$


Los resultados obtenidos en este trabajo permiten avanzar en el conocimiento de la distribución y estructura de la diversidad genética a lo largo del continente americano del chirimoyo (Annona cherimola Mill), una especie infrautilizada y adaptada a climas subtropicales. En primer lugar se aportan nuevos marcadores para las siete especies del género con mayor importancia agronómica y un análisis de diferenciación de especies de este grupo por DNA barcoding que permiten distinguir claramente el chirimoyo de otras especies cultivadas cercanas genéticamente (capítulo 1 y 2). A su vez, estas especies se incluyen en el análisis filogenético de 17 especies del género (capítulo 3). Una vez disponible la metodología para la identificación de las muestras de la especie Annona cherimola se ha podido establecer la distribución de su diversidad genética desde el extremo norte al extremo sur de su distribución en el continente americano (capítulo 4). Finalmente, se ha llevado a cabo un estudio de genética del paisaje que ayuda a entender su dispersión (capítulo 5). Los resultados obtenidos, además de tener claras implicaciones para la conservación y uso sostenible de los recursos genéticos de este cultivo, puede ayudar a inferir la región de origen de esta especie y abren las puertas para llevar a cabo estudios similares en otros cultivos frutales nativos de Latinoamérica, como el aguacate (Persea americana Mill.).

\section{Origen y dispersión de A. cherimola}

El chirimoyo pertenece al género Annona, que habría surgido durante el Mioceno, hace 5 $23 \mathrm{Ma}$ (Richardsson et al. 2004; Su \& Saunders 2009), y éste, a su vez, es parte de la familia de angiospermas basales Annonaceae. Los resultados obtenidos en este trabajo indican que esta especie probablemente tuvo su origen en la región centroamericana, donde actualmente sus parientes más cercanos, pertenecientes también a la sección Atta o similares (Fries 1959), con los que mostró conformar un grupo monofilético (capítulo 3), están distribuidos. Además, los individuos de Annona cherimola incluidos en este trabajo de filogenia, elaborado con la secuencia de cinco regiones parciales de loci cloroplastídicos, provenientes de 10 países diferentes (México, Guatemala, Honduras, Costa Rica, Colombia, Ecuador, Perú, Bolivia, Madeira (Portugal) y España) revelaron una cierta estructura poblacional. En la base de la rama que incluía a todas ellas, se encontraron las muestras hondureñas y mexicana, dando a entender que se trata de los individuos que portan un genotipo (para los cinco marcadores estudiados) más ancestral. Por otro lado, la distribución espacial de diferentes índices utilizados en la medida de diversidad genética (heterocigosidad esperada, heterocigosidad observada, índice de Shannon o riqueza alélica) muestran valores más elevados en la región centroamericana, concretamente en Guatemala y Honduras (capítulos 4 y 5) después de analizar un total de 1.843 accesiones, provenientes de ocho países diferentes (México, Guatemala, Honduras, Costa Rica, Colombia, Ecuador, Perú y Bolivia), 
con marcadores neutros (tipo microsatélite). La diversidad actual de las especies que se genera como resultado de mutación, selección natural, deriva genética y flujo genético, se ha creado, en gran parte, durante tiempos geológicos. $\mathrm{Y}$, por tanto, pese a que centros de diversidad no necesariamente señalan los centros de origen de las especies, sí nos pueden dar una idea del "reloj biológico" de sus poblaciones. Así, es razonable pensar que las poblaciones situadas en Guatemala y Honduras podrían ser las que lleven asentadas más tiempo. El hecho de que de un total de 177 alelos encontrados en todas las muestras, el $98.9 \%$ (175) estén presentes en las muestras centroamericanas y mexicanas (capítulo 5), pese a que el número de accesiones de esta zona suponen un 18.45\% (340 de 1843) del total muestreado, también apoya esta hipótesis. Sin embargo, ello no necesariamente significa que estas accesiones no puedan provenir, a su vez, de otras poblaciones procedentes de lugares de los que no se disponen muestras para su análisis en este estudio o donde ya no esté presente esta especie.

La dispersión inicial de esta especie por la región central y septentrional de América pudo haber estado mediada por la megafauna que habitó este continente durante 20 Ma y que se extinguió hace unos 13.000 años (Barlow 2001). A las especies cuyos frutos tienen características típicas que se explicarían por interacción con animales extintos, se les llama anacronismos y tanto el chirimoyo y otras anonáceas como el aguacate pueden ser consideradas como tales. Se han descrito dos tipos de frutos carnosos cuya dispersión pudo depender de la megafauna extinta en el pleistoceno: i) entre 4 y $10 \mathrm{~cm}$ de diámetro, con hasta cinco semillas de más de $2 \mathrm{~cm}$ de diámetro y ii) mayores a $10 \mathrm{~cm}$ de diámetro con más de cien semillas en su interior (Guimaraes et al. 2008). La chirimoya sería como otros frutos del género Theobroma, con multiples semillas relativamente grandes. Una vez extinguida la megafauna americana la dispersión posterior de estas especies dependería principalmente del ser humano.

Es posible que la civilización maya, que se extendió por buena parte de Mesoamérica, concretamente en el sureste de México, Guatemala, Belice, El Salvador y oeste de Honduras, utilizase los recursos genéticos del chirimoyo. Esta civilización, cuyo progreso se divide en tres etapas; preclásico (2000 AC - 250 DC), clásico (250 - 900DC) y postclásico (900 - 1524 DC) (Sharer 2012; Osuna 2015) se caracterizaba, entre otras cosas, por su desarrollada escritura y sistema métrico, observaciones astronómicas y sofisticada agricultura. De hecho, Lhullier (1981) nombra a la chirimoya o anona (nombre vulgar dado en la región centroamericana a la $A$. cherimola y a otras especies cercanas del género) como un recurso habitual de los pueblos mayas. Es de interés que Linneo utilizase esta denominación centroamericana para designar al género pero refiriéndose a él como derivado del término latín "annona" que puede traducirse como "la producción annual de un cultivo" (Linnaeus 
1737). Además de los mayas, otras culturas se desarrollaron también en Mesoamérica durante tiempos precolombinos. Entre ellas, en el periodo preclásico la Cultura Olmeca en la Costa del Golfo de México (1.200-500 AC) o Cultura de Izapa en Guatemala (300-100 AC). En el periodo clásico la Cultura de Teotihuacán, en el centro de México (200 - 650 DC), o Cultura de Monte Albán en el oeste del territorio (10 - 950 DC) y en el postclásico la Cultura Tolteca (950 DC - 1250 DC) y Mexica - Tenocha (1325 DC-1519 DC) en el centro; y Mixtecos en el oeste (1250 DC -1.519 DC) del mismo país norteamericano (Morgado 2007). Varios de estos pueblos pudieron contribuir a la dispersión de la chirimoya por el continente. Muchas son las especies que se consideran haber sido domesticadas en la zona Mesoamericana, desde hace $~ 7000$ años hasta la actualidad, como Zea mays, Cucurbita pepo, Amaranthus cruentus o varias especies del género Phaseolus (Pickersgill 2007).

La especie Annona cherimola pudo haber empezado a ser recolectada y cultivada por los pueblos mesoamericanos para, en algún momento, ser trasportada a Sudamérica donde continuaría su cultivo y diversificación mediada por la actividad humana de las diferentes civilizaciones Andinas. De hecho, los análisis de estructura genética muestran que unas pocas accesiones, presentes en el norte de Perú, se agruparían con las accesiones de Guatemala, Honduras y Costa Rica (capítulo 4). Entre las muestras colectadas en los diferentes países centroamericanos para el presente estudio, hubo algunas accesiones que parecían provenir de poblaciones silvestres, mientas que una gran parte de las muestras provenían de hojas de árboles semi-cultivados (sin apenas manejo o cuidados) en los patios traseros de la casas o en lindes de zonas rurales. La variación fenotípica observada (no medida) en la región centroamericana parece ser menor de la que se observa en las zonas del norte de Perú y sur de Ecuador (Scheldeman, comunicación personal) mientras que ocurre completamente lo contrario con la diversidad genética analizada (Capítulos 3 y 5). Así, el chirimoyo encajaría en la descripción de una especie semi-domesticada (Clement 1999), pues hay poblaciones que difieren en su variación fenotípica de las poblaciones silvestres, siendo en muchos casos mayor (Sudamérica vs Centroamérica), mientras que la variación genética va disminuyendo a medida que hay más selección humana (norte de Ecuador Colombia o sur de Perú y Bolivia). De la misma manera todos los alelos amplificados con los marcadores microsatélites presentes en Sudamérica (excepto dos) están también presentes en individuos de las poblaciones de Centroamérica (Capítulo 4 y 5), mientras que tan sólo uno de los dos haplotipos encontrados en la secuencia matK parece haberse dispersado desde Honduras, donde aparecen los dos a partes iguales (capítulo 2). Todo esto apunta a un gran cuello de botella previo a la formación de las poblaciones del sur, como ya ha sido reportado para otras especies de origen Mesoamericano como Phaseolus vulgaris (Bitochi et al. 2012, 2013). 
Además de los datos obtenidos a raíz de los marcadores microsatélite, otras observaciones apuntan a un origen centroamericano de la especie. Así, Annona cherimola sería la única representante de la sección Atta y especies genéticamente próximas en América del Sur, ya que el resto de las especies de la sección están naturalmente presentes solamente en América Central y sur de América del Norte. Por tanto, si asumimos un origen centroamericano de la especie, las evidencias apuntan a que un pequeño número de accesiones pudo haber llegado al norte de Perú y dispersado a partir de ahí tanto hacia el norte (Ecuador y Colombia) como hacia el sur (sur de Perú y Bolivia y, quizás Chile). De hecho, sería interesante poder estudiar un mayor número de poblaciones colombianas y chilenas lo más semi-cultivadas posible (para evitar movimientos de material recientes) y comprobar si siguen el mismo patrón encontrado en este trabajo. Esta hipótesis se contrapone con la hipótesis hasta la fecha aceptada, de que $A$. cherimola se habría originado en los valles interandinos del norte de Perú y sur de Ecuador. Las evidencias que apoyaban esta hipótesis eran la alta diversidad fenotípica encontrada en estas áreas (Popenoe 1912), la aparición de cerámicas con la forma de chirimoya en yacimientos arqueológicos de las culturas Mochica y Chimu (Museo de la Nación 1995), y de semillas que se atribuyen a esta especie (Bonavia et al. 2004). Así, semillas de A. cherimola se habrían encontrado en la península de Santa Elena en Ecuador (Berry 1929), en la cueva de los Gavilanes (2700 años AC), en el valle de Huarmey al sur de Ancash (Museo de la Nación, 1995) o en Ancón (2000 años AC), cerca de Lima (Towle 1961), pero no así en la cueva de Ancash (Guitarrero) que se ha datado en 8.000 años $A C$ y donde se han descrito restos de otras plantas. A pesar de que las semillas no pueden ser consideradas como un buen discriminante entre especies de género Annona ya que son muy parecidas entre especies cercanas (Koek-Noorman 1987) o que las cerámicas arqueológicas pudieran representar otras especies como $A$. squamosa (también de origen centroamericano) o $A$. muricata (especie de requerimientos más tropicales de origen todavía incierto), estos datos ponen de manifiesto que la especie pudo estar presente entre 2000/2700 AC en Sudamérica. Los resultados aquí expuestos señalan al centro de Perú como el centro de diversificación en América del Sur (capítulos 4 y 5; van Zonneveld et al. 2012). La llegada del chirimoyo, desde Mesoamérica, pudo haber sido por mar, posiblemente desde el oeste de México (capítulo 5), aunque no debe descartarse ninguna otra posibilidad que no haya sido incluida en las nueve rutas testadas en este trabajo. La existencia de rutas e intercambios entre Ecuador/Perú y México está documentada en la bibliografía basada en datos arqueológicos, metalúrgicos o lingüísticos (Wolters 2001; Marcos 2005). Esta vía de dispersión pudo ser también la responsable de la extensión de otros recursos fitogenéticos por el continente americano en tiempos precolombinos, no así el maíz, que probablemente se dispersara por tierra con los primeros intercambios entre las poblaciones humanas (capítulo 5). 
El hecho de utilizar una especie arbórea infrautilizada actualmente en la mayoría de las áreas dónde ha mostrado más diversidad genética, y semi domesticada, hace que las accesiones (semi) cultivadas estén separadas por pocas generaciones de sus parientes silvestres y mantengan una parte intacta de la huella de sus primeros movimientos, lo que es de gran ayuda para inferir los procesos de migración y flujo genético, que han llevado a la distribución actual de la diversidad.

\section{Conservación de los recursos de Annona cherimola}

La conservación y uso sostenible de los recursos genéticos del chirimoyo en su lugar de origen es de gran importancia para el mantenimiento de su diversidad y su utilización para proyectos de mejora genética de la especie en el futuro. Según nuestro conocimiento, sólo existen dos colecciones de campo, ex situ, de accesiones de chirimoyo y otras anonas en Mesoamérica, concretamente en los estados de Michoacán y de México (México). En Guatemala y, especialmente en Honduras, da la sensación de que las frutas de chirimoyo son un recurso de difícil acceso en las grandes ciudades quedando confinado a las zonas rurales y donde se ha producido una disminución en la importancia del cultivo dando lugar, posiblemente, a una significante erosión genética. Hoy en día, el banco de germoplasma de referencia mundial de esta especie es el situado en el Instituto de Hortofruticultura Mediterránea y Subtropical La Mayora (IHSM-UMA-CSIC) instituto mixto del Consejo Superior de Investigaciones Científicas y la Universidad de Málaga, con unas 300 accesiones de Annona cherimola. De éstas, aproximadamente 2/3 provienen de América del Sur, principalmente de Perú y Ecuador. De la zona Mesoamericana sólo 6 tienen un origen mexicano y una costarricense aunque 36 provienen de una colección de California mantenida en un vivero comercial teniendo, a su vez, posiblemente un origen centroamericano. Por tanto, existe un sesgo en esta colección de referencia hacia la sobrerrepresentación en la misma de accesiones sudamericanas debido a la hipótesis generalmente admitida de un origen sudamericano de la especie. Sería de interés completar las accesiones del banco con material genético procedente de América Central.

Por otra parte, los modelos de distribución bajo el contexto de las predicciones actuales de cambio climático, señalan que las áreas en las que ahora se encuentran las poblaciones más diversas de chirimoyo dejarían de ser propicias para el cultivo de esta especie (capítulo 4). En este sentido, la especie se vería desplazada a localizaciones más altas (y por tanto más frías) en su lugar de origen, pudiéndose perder numerosos genotipos en el proceso. Todo esto, sumado a otras amenazas, incluso más inminentes, como el cambio de uso de suelo, la fragmentación de hábitats o el aumento de la accesibilidad (van Zonneveld et al. 2009, Samuel et al. 2013) hacen urgentes los proyectos de conservación, 
tanto in situ como ex situ, en la zona de origen o de máxima diversidad. En una fase posterior podrían empezarse diversos ensayos de caracterización agronómica para empezar a seleccionar genotipos de interés adaptados a las diferentes regiones ecológicas de la región.

\section{Relaciones filogenéticas en el género Annona}

En la mayoría de los proyectos relacionados con la conservación y el uso de los recursos genéticos de plantas, es necesaria una correcta identificación de la especie o especies en cuestión. En este sentido, el gen matK cloroplastídico es capaz de diferenciar las especies con mayor interés agronómico del género Annona ( $A$. cherimola, $A$. reticulata, $A$. squamosa, A. muricata, A. macroprophyllata, A. glabra, y A. purpurea), así como otras especies del género disponibles en la base de datos BOLD (capítulo 1). Conjuntamente, se utilizaron SNPs presentes en cada una de las siete especies mencionadas para el diseño de marcadores que permitieran una identificación rápida mediante ausencia o presencia de banda en gel. Se amplificaron varios individuos de cada una de ellas para captar la mayor variabilidad genética intraespecífica posible. A pesar de esto último, la aplicación de los marcadores diseñados de chirimoyo en un gran número de accesiones (546) de esta especie, provenientes del banco de referencia mundial localizado en el IHSM-UMA-CSIC, y de recolecciones realizadas en tres países centroamericanos, pusieron de manifiesto la existencia de dos haplotipos diferentes en cuanto a los SNPs utilizados para el diseño de los cebadores (capítulo 2). Así, solamente se han encontrado dos combinaciones (presencia o ausencia) de ambos SNPs; además dichas combinaciones están correlacionadas con la región geográfica. El haplotipo con los dos SNPs variantes habría sido dispersado desde Honduras/Guatemala, mientras que el similar al resto de especies estudiadas habría permanecido principalmente en Mesoamérica. Se reporta un nuevo marcador de chirimoyo (capítulo 2), basado en el locus trnL-F, capaz de amplificar todas las accesiones estudiadas pero que también podría hacerlo en la especie Annona pruinosa y otras no incluidas en el análisis. En este sentido, ninguna de las combinaciones de los cinco genes utilizados en el capítulo 4 es capaz de diferenciar ni de permitir elaborar una historia evolutiva diferente para las especies Annona cherimola y Annona pruinosa. De hecho, tanto los dos individuos de Annona pruinosa como las dos chirimoyas, que agrupan con ellas en la base del clado que conforman, carecen de los SNPs específicos de chirimoya del gen matK. Una posible explicación para todo esto, que requeriría de estudios comparativos adicionales, sería el posible origen híbrido del chirimoyo. Así, algunos linajes del chirimoyo habrían heredado el ADN del cloroplasto de una especie parental (que podría ser Annona pruinosa) y otros, el de la otra. Estos resultados podrían explicar las frecuentes anomalías meióticas descritas en 
cruzamientos intraespecíficos e interespecíficos en los que participa $A$. cherimola (Martín 2013). En este sentido, recientemente, se ha comenzado en el Departamento de Fruticultura del IHSM-UMA-CSIC un proyecto de secuenciación por Illumina HiSeq de ADN rico en ADN cloroplastídico de cuatro accesiones de chirimoyo con diferente origen geográfico y una accesión de $A$. pruinosa. La obtención de los genomas ensamblados y anotados, usando como ADN de referencia la secuencia de ADN cloroplastídico de una accesión de chirimoyo recientemente publicada (Blazier et al. 2016), permitirán profundizar en la relación entre estas dos especies y algunas de sus variantes geográficas. Finalmente los resultados del ensayo filogenético (capítulo 3) muestran que las secciones del género Annona, Atta y cercanas, como llama o Chalenocarpus, necesitan ser revisadas puesto que a pesar de estar englobadas en un mismo clado, no muestran grupos monofiléticos independientes. 


$$
\text { E: }
$$


1) La secuencia parcial del gen cloroplastídico matK permitió diferenciar 12 especies de Annona, incluyendo las secuencias de tres individuos con distinto origen geográfico de cada una de las 7 especies con mayor importancia agronómica y aquellas descargadas de BOLD, con técnicas de distancia de código de barras de plantas.

2) El alineamiento construido anteriormente con la secuencia matK seleccionada, permitió el diseño de cebadores para cada una de las 7 especies mencionadas con objeto de poder diferenciarlas realizando una reacción en cadena de la polimerasa y comprobación de presencia o ausencia de banda en gel.

3) El marcador de chirimoyo previamente diseñado se utilizó para analizar 546 accesiones, lo que puso de manifiesto la presencia de dos combinaciones con dos polimorfismos de nucleótido simple diferentes cada una. Una de ellas estuvo presente únicamente en las accesiones de la zona centroamericana (principalmente en Honduras) mientras que la otra lo estuvo también en el resto de lugares de origen de las muestras analizadas.

4) Se diseñó un segundo marcador para la diferenciación de chirimoyo respecto al resto de especies de interés agronómico basado en la secuencia trnL-F que permitió amplificar prácticamente todas las accesiones anteriores.

5) Las especies de la sección Atta y cercanas, Chalenocarpus e llama, todas (excepto A. cherimola) con distribución centroamericana, conformaron un grupo monofilético a pesar de no mostrar reciprocidad monofilética (a nivel de sección), tanto en el árbol de máxima verosimilitud como en el de inferencia bayesiana construidos a partir del alineamiento de 46 muestras de ADN pertenecientes a 17 especies del género Annona y tres genes cloroplastídicos codificantes, apuntando a un origen mesoamericano de $A$. cherimola.

6) Las 13 accesiones de chirimoyo incluidas en el trabajo filogenético se agruparon en un mismo clado del árbol estando en la base del mismo las muestras hondureñas, mexicana, y las accesiones de Annona pruinosa, señalando la cercanía de ambas especies y apoyando el origen mesoamericano del chirimoyo.

7) El estudio de la distribución espacial de la diversidad de Annona cherimola medida con microsatélites en más de 1800 especímenes a lo largo de todo su área de distribución en el 
continente americano, mostró que las zonas de máxima diversidad genética se localizan en Centroamérica (principalmente Honduras y Guatemala), seguidas, con una disminución marcada, por el norte de Perú y sur de Ecuador. Este patrón también se reproduce por el número de alelos total y número de alelos únicos presentes en cada una de las zonas lo que apoya la hipótesis del origen mesoamericano de la especie.

8) Gran parte de las zonas actuales climáticamente propicias para el crecimiento del chirimoyo, donde se sitúan las poblaciones más diversas, dejarían de serlo en 50 años, lo que manifiesta la necesidad de poner en marcha proyectos de conservación de los recursos genéticos de esta especie en su centro de máxima diversidad, según los modelos de máxima entropía generados.

9) Los modelos de aislamiento por distancia construidos revelaron que la dispersión desde Norteamérica/Centroamérica a Sudamérica pudo tener lugar a través de una ruta marítima entre el suroeste de México y el Norte de Perú. Además, el clima y rutas de comercio precolombinas parecen tener una clara importancia en la diseminación del cultivo por América del Sur. 


$$
20
$$


Alaly FQ, Liu XX, McLaughlin JL (1999) Annonaceous acetogenins: recent progress. Journal of Natural Products, 62: 504-540.

Alberts B, Johnson A, Lewis J, Raff M, Roberts K, Walter P (2002) Molecular Biology of the Cell. 4th edition. Garland Science, New York.

Akaike H (1974) A new look at the statistical identification model. IEEE Transactions on Automatic Control, 19(6): 716-723.

Amar MH, Biswas MK, Zhang Z, Guo WW (2011) Exploitation of SSR, SRAP and CAPS-SNP markers for genetic diversity of Citrus germplasm collection. Scientia Horticulturae, 128: 220-227.

Amel SH, Mokhtar T, Salwa Z, Jihene H, Messaoud M, Abdelmajid R, Mohamed M (2004) Intersimple sequence repeat fingerprints to assess genetic diversity in Tunisian fig (Ficus carica L.) germplasm. Genetic Resources and Crop Evolution, 51: 269-275.

Amel SH, Khaled C, Messaoud M, Mohamed M, Mokhtar T (2005) Comparative analysis of genetic diversity in two Tunisian collections of fig cultivars based on random amplified polymorphic DNA and inter simple sequence repeats fingerprints. Genetic Resources and Crop Evolution, 52: 563-573.

Andrés J, González F, Nieto R, Barrientos AF (2006) Morphometry of the organs of cherimoya (Annona cherimola Mill.) and analysis of fruit parameters for the characterization of cultivars, and Mexican germplasm selections. Scientia Horticulturae, 107: 337-346.

APG III (2009) An update of the Angiosperm Phylogeny Group classification for the orders and families of flowering plants: APG III. Botanical Journal of the Linnean Society, 161: 105-121.

Aubriot X, Lowry PP 2nd, Cruaud C, Couloux A, Haevermans T (2013) DNA barcoding in a biodiversity hot spot: potential value for the identification of Malagasy Euphorbia L. listed in CITES Appendices I and II. Molecular Ecology Resources, 13: 57-65.

Baldauf SL (2003) Phylogeny for the faint of heart: a tutorial. Trends in Genetics, 19(6): 345-51.

Barlow C (2000) The ghosts of evolution: nonsensical fruit, missing partners, and other ecological anachronisms. Basic Books, New York.

Basheer-Salimia R, Lorenzi S, Batarseh F, Moreno-Sanz P, Emanuelli F, Grando MS (2014) Molecular identification and genetic relationships of Palestinian grapevine cultivars. Molecular Biotechnology, 56: 546-556.

Beghe D, Ganino T, Dall'Asta C, Silvanini A, Cirlini M, Fabbri A (2013) Identification and characterization of ancient Italian chestnut using nuclear microsatellite markers. Scientia Horticulturae 164: 50-57.

Berry EW (1929) Fossil fruits in the Ancon Sandstone of Ecuador. Journal of Paleontology, 3: 298-299.

Bioversity International and CHERLA (2008) Cherimoya descriptors for cherimoya (Annona cherimola Mill.). Bioversity International, Rome, Italy. CHERLA Project, Malaga, Spain. 
Bitocchi E, Nanni L, Bellucci E, Rossi M, Giardini A, Zeuli PS, Logozzo G, Stougaard J, McClean P, Attene G, Papa R (2012) Mesoamerican origin of the common bean (Phaseolus vulgaris L.) is revealed by sequence data. Proceedings of the National Academy of Sciences USA, 109: 788-796.

Bitocchi E, Bellucci E, Giardini A, Rau D, Rodriguez M, Biagetti E, Santilocchi R, Zeuli PS, Gioia T, Logozzo G, Attene G, Nanni L, Papa R (2013) Molecular analysis of the parallel domestication of the common bean (Phaseolus vulgaris) in Mesoamerica and the Andes. New Phytologist, 197: 300313.

Bhargava M, Sharma A (2013) DNA barcoding in plants: evolution and applications of in silico approaches and resources. Molecular Phylogenetics and Evolution, 67: 631-641.

Bivand R, Lewin-Koh N (2015) Maptools: Tools for reading and handling spatial objects. R package version 0.8-34. [WWW document] URL http://CRAN.R-project.org/package=maptools [accessed 29 March 2016].

Bivand R, Rundel C (2015) Rgeos: Interface to Geometry Engine - Open Source (GEOS). R package version 0.3-12. [WWW document] URL http://CRAN.R-project.org/package=rgeos [accessed 29 March 2016].

Bivand R, Keitt T, Rowlingson B (2014) Rgdal: Bindings for the geospatial data abstraction library. R package version 0.9-1. [WWW document] URL http://CRAN.R-project.org/package=rgdal [accessed 29 March 2016].

Bjornstad ON (2013) ncf: spatial nonparametric covariance functions. $R$ package version 1.1-5. http://CRAN.R-project.org/package=ncf [accessed 29 March 2016].

Blazier JC, Ruhlman TA, Weng ML, Rehman SK, JSM Sabir, Jansen RK (2016) Divergence of RNA polymerase a subunits in angiosperm plastid genomes is mediated by genomic rearrangement. Scientific Reports, 6: 24595.

Bonavia D, Ochoa CM, Tovar SO, Palomino RC (2004) Archaeological evidence of cherimoya (Annona cherimola Mill.) and guanabana (Annona muricata L.) in ancient Peru. Economic Botany, 58: 509-522.

Bost JB, Smith NJH, Crane JH (2013) History, distribution and uses. The Avocado: Botany, Production and Uses. Eds: Schaffer B, Wolstenholme BN, Whiley AW. CAB International, Wallingford, UK, 10-30.

Bowden WM (1948) Chromosome numbers in the Annonaceae. American Journal of Botany, 35(7): 377-381.

Brake M, Migdadi H, Al-Gharaibeh M, Ayoub S, Haddad N, El Oqlah A (2014) Characterization of Jordanian olive cultivars (Olea europaea L.) using RAPD and ISSR molecular markers. Scientia Horticulturae, 176: 282-289.

Breto MP, Ruiz C, Pina JA, Asins MJ (2001) The diversification of Citrus clementina Hort. ex Tan., a vegetatively propagated crop species. Molecular Phylogenetics and Evolution, 21: 285-293. 
Brown AHD (1978) Isozymes, plant population genetic structure and genetic conservation. Theoretical and Applied Genetics, 52: 145-157.

Brown W (1983) Genetic diversity and genetic vulnerability: an appraisal. Economic Botany, 37: 4-12.

Brown JL (2014) SDM toolbox: a python-based GIS toolkit for landscape genetic, biogeographic, and species distribution model analyses. Methods in Ecology and Evolution, 5: 694-700.

Bydekerke L, Van Ranst E, Scheldeman X, Van Damme P (1999) Edaphoclimatological study of cherimoya (Annona cherimola Mill.) in Loja province, Southern Ecuador. Proceedings of the first international symposium on cherimoya. Acta Horticulturae, 497: 71-90.

Carballo DM (2012) Trade routes in the Americas before Columbus. The great trade routes: A history of cargos and commerce over land and sea. Ed: Philip Parker. Conway Publishing, London, 166-170.

Cassini MH (2013) Distribution ecology. From individual habitat use to species biogeographical range.

Springer-Verlag, New York.

Cassman KG (1999) Ecological intensification of cereal production systems: Yield potential, soil quality, and precision agriculture. Proceedings of the National Academy of Sciences USA, 96: 59525959.

CBOL Plant Working Group (2009) A DNA barcode for land plants. Proceedings of the National Academy of Sciences, 106: 12794-12797.

Chaowasku T, Thomas DC, van der Ham RW, Smets EF, Mols JB, Chatrou LW (2014) A plastid DNA phylogeny of tribe Miliuseae: insights into relationships and character evolution in one of the most recalcitrant major clades of Annonaceae. American Journal of Botany, 101: 691-709.

Chase MW, Cowan RS, Hollingsworth PM, van den Berg C, Madrinan S, Petersen G, Seberg O, Jørgsensen T, Cameron KM, Carine M, Pedersen N, Hedderson TAJ, Conrad F, Salazar GA, Richardson JE, Hollingsworth ML, Barraclough TG, Kelly L, Wilkinson M (2007) A proposal for a standardised protocol to barcode all land plants. Taxon, 56: 295-299.

Chatrou LW (1999). Annonaceae and the Annonaceae Project: A brief overview of the state of affairs. Acta Horticulturae 497: 43-49.

Chatrou LW, Rainer H, Maas PJM (2004) Annonaceae, Flowering plants of the neotropics. Eds: Smith N, Mori SA, Henderson A, Stevenson DW, Heald SV. Princeton University Press, Princeton, 1820.

Chatrou LW, Escribano MP, Viruel MA, Maas JW, Richardson JE, Hormaza JI (2009) Flanking regions of monomorphic microsatellite loci provide a new source of data for plant species-level phylogenetics. Molecular Phylogenetics and Evolution, 53: 726-733.

Chatrou LW, Pirie MD, Erkens RHJ, Couvreur TLP, Neubig KM, Abbott JR, Mols JB, Maas JW, Saunders RMK, Chase MW (2012) A new subfamilial and tribal classification of the pantropical flowering plant family Annonaceae informed by molecular phylogenetics. Botanical Journal of the Linnean Society, 169: 5-40. 
Chen SL, Yao H, Han JP, Liu C, Song JY, Shi LC, Zhu YJ, Ma XY, Gao T, Pang XH, Luo K, Li Y, Li XW, Jia XC, Lin YL, Leon C (2010) Validation of the ITS2 region as a novel DNA barcode for identifying medicinal plant species. PLoS One, 5: e8613.

China Plant BOL Group, Li DZ, Gao LM, Li HT, Wang H, Ge XJ, Liu JQ, Chen ZD, Zhou SL, Chen SL, Yang JB, Fu CX, Zeng CX, Yan HF, Zhu YJ, Sun YS, Chen SY, Zhao L, Wang K, Yang T, Duan GW (2011) Comparative analysis of a large dataset indicates that internal transcribed spacer (ITS) should be incorporated into the core barcode for seed plants. Proceedings of the National Academy of Sciences of the United States of America, 108: 19641-19646.

Cho KH, Cho KS, Han JH, Kim HR, Shin IS, Kim SH, Chun JA, Hwang HS (2013) Development of sequence characterized amplified region markers for cultivar identification in persimmon. Korean Journal of Horticultural Science \& Technology, 31:798-806.

Clement CR (1999) 1492 and the loss of Amazonian crop genetic resources. The relation between domestication and human population decline. Economic Botany, 53: 188-202.

Cobo PB (1653) Historia del Nuevo Mundo. Sociedad de Bibliófilos Andaluces, Seville, Spain (1891).

Collins RA, Cruickshank RH (2013) The seven deadly sins of DNA barcoding. Molecular Ecology Resources, 13: 969-975.

Collins WJ, Bellouin N, Doutriaux-Boucher M, Gedney N, Halloran P, Hinton T, Hughes J, Jones CD, Joshi M, Liddicoat S, Martin G, O'Connor F, Rae J, Senior C, Sitch S, Totterdell I, Wiltshire A, Woodward S. (2011) Development and evaluation of an Earth-System model - HadGEM2. Geoscientific Model Development, 4: 1051-1075.

Cortes D, Moreno L, Párraga J, Galán A, Cabedo N (2014) Nuevos fármacos inspirados en Annonáceas. Revista Brasileira de Fruticultura, 36(spe1): 22-31.

Couvreur TL, van der Ham RW, Mbele YM, Mbago FM, Johnson DM (2009) Molecular and morphological characterization of a new monotypic genus of Annonaceae, Mwasumbia, from Tanzania. Systematic Botany, 34(2): 266-276.

Cracraft J (1983) Species concepts and speciation analysis. Current Ornitology, 1: 159-187.

Crowhurst RN, Gleave AP, MacRae EA, Ampomah-Dwamena C, Atkinson RG, Beuning LL, Bulley SM, Chagne D, Marsh KB, Matich AJ, Montefiori M, Newcomb RD, Schaffer RJ, Usadel B, Allan AC, Boldingh HL, Bowen JH, Davy MW, Eckloff R, Ferguson AR, Fraser LG, Gera E, Hellens RP, Janssen BJ, Klages K, Lo KR, MacDiarmid RM, Nain B, McNeilage MA, Rassam M, Richardson AC, Rikkerink EHA, Ross GS, Schröder R, Snowden KC, Souleyre EJF, Templeton MD, Walton EF, Wang D, Wang MY, Wang YY, Wood M, Wu R, Yauk YK, Laing WA (2008) Analysis of expressed sequence tags from Actinidia: Applications of a cross species EST database for gene discovery in the areas of flavor, health, color and ripening. BMC Genomics, 9: 351.

Daly DC, Cameron KM, Stevenson DW (2001) Plant systematics in the age of genomics. Plant Physiology, 127:1328-1333. 
Darriba D, Taboada GL, Doallo R, Posada D (2012) jModelTest 2: more models, new heuristics and parallel computing. Nature Methods 9(8): 772.

Darwin CR (1835) Beagle diary (1831-1836). [WWW document] URL http://darwinonline.org.uk/ content/frameset?pageseq=1\&itemID=EHBeagleDiary\&viewtype=text. [accessed 29 March 2016].

Darwin CR (1859) Variation under domestication. On the Origin of Species by Means of Natural Selection, or the Preservation of Favoured Races in the Struggle for Life. John Murray, London.

De Groot GA, During HJ, Maas JW, Schneider H, Vogel JC, Erkens RHJ (2011) Use of rbcL and trnL-F as a Two-Locus DNA Barcode for Identification of NW-European Ferns: An Ecological Perspective. PLoS ONE, 6(1): e16371.

De Queiroz K (2007) Species concepts and species delimitation. Systematic Biology, 56 (6): 879-886.

DeSalle R, Egan MG, Siddall M (2005) The unholy trinity: taxonomy, species delimitation and DNA barcoding. Philosophical Transactions of the Royal Society B-Biological Sciences, 360: 1905-1916.

De Vere N, Rich TCG, Ford CR, Trinder SA, Long C, Moore CW, Satterthwaite D, Davies H, Allainguillaume J, Ronca S, Tatarinova T, Garbett H, Walker K, Wilkinson MJ (2012) DNA barcoding the native flowering plants and conifers of Wales. PLoS One, 7: e37945.

De Vicente MC, López C, Fulton T (eds.) (2004) Genetic diversity analysis with molecular marker data: Learning Module. International Plant Genetic Resources Institute (IPGRI), Rome, Italy.

Doyle JA, Le Thomas A (1994) Cladistic analysis and pollen evolution in Annonaceae. Acta Botanica Gallica, 141: 149-170.

Doyle JA, Le Thomas A (1996) Phylogenetic analysis and character evolution in Annonaceae. Bulletin du Muséum National d'Histoire Naturelle, Section B, Adansonia, 18: 279-334.

Doyle JA, Le Thomas A (1997) Phylogeny and geographic history of Annonaceae. Geographie Physique et Quaternaire, 51: 353-361.

Doyle JA, Le Thomas A (2012) Evolution and phylogenetic significance of pollen in Annonaceae. Botanical Journal of the Linnean Society, 169: 190-221.

Du X, Zhang Q, Luo Z (2009a) Development of retrotransposon primers and their utilization for germplasm identification in Diospyros spp. (Ebenaceae). Tree Genetics \& Genomes, 5:235-245.

Du XY, Zhang QL, Luo Z (2009b) Comparison of four molecular markers for genetic analysis in Diospyros L. (Ebenaceae). Plant Systematics and Evolution, 281: 171-18.

Dvorak J, Luo MC, Akhunov ED (2011) N.I. Vavilov's theory of centres of diversity in the light of current understanding of wheat diversity, domestication and evolution. Czech Journal of Genetics and Plant Breeding, 47: 20-27.

Ellegren H (2000) Microsatellite mutations in the germline: implications for evolutionary inference. Trends in Genetics, 16: 551-558.

Ellegren H (2004) Microsatellites: simple sequences with complex evolution. Nature Reviews Genetics, 5: 435-445. 
Ellstrand NC, Lee JM (1987) Cultivar identification of cherimoya (Annona cherimola Mill) using isozyme markers. Scientia Horticulturae, 32: 25-31.

Enan MR, Ahamed A (2014) DNA barcoding based on plastid matK and RNA polymerase for assessing the genetic identity of date (Phoenix dactylifera L.) cultivars. Genetic and Molecular Research, 13(2): 3527-3536.

Erkens RHJ, Chatrou LW, Couvreur, TLP (2012a) Radiations and key innovations in an early branching angiosperm lineage (Annonaceae; Magnoliales). Botanical Journal of the Linnean Society, 169(1): 117-134.

Erkens RHJ, Mennega EA, Westra LYT (2012b) A concise bibliographic overview of Annonaceae. Botanical Journal of the Linnean Society, 169:41-73.

Ernest HB, Vickers TW, Morrison SA, Buchalski MR, Boyce WM (2014) Fractured genetic connectivity threatens a Southern California puma (Puma concolor) population. PLoS One, 9: e107985.

Escribano P (2007) Desarrollo de marcadores moleculares para la identificación de genotipos, estudios de diversidad y mejora de chirimoyo (Annona cherimola Mill.). Tesis doctoral, Universidad de Málaga.

Escribano P, Viruel MA, Hormaza JI (2004) Characterization and cross-species amplification of microsatellite markers in cherimoya (Annona cherimola Mill., Annonaceae). Molecular Ecology Notes, 4: 746-748.

Escribano P, Viruel MA, Hormaza JI (2007) Molecular analysis of genetic diversity and geographic origin within an ex situ germplasm collection of cherimoya by using SSRs. Journal of the American Society for Horticultural Science, 132(3): 357-367.

Escribano P, Viruel MA, Hormaza JI (2008a) Comparison of different methods to construct a core germplasm collection in woody perennial species with SSR markers. A case study in cherimoya (Annona cherimola Mill.), an underutilized subtropical fruit tree species. Annals of Applied Biology, 153: 25-32.

Escribano P, Viruel MA, Hormaza JI (2008b) Development of new 52 polymorphic SSR markers from cherimoya (Annona cherimola Mill.). Transferability in related taxa and selection of a reduced set for DNA fingerprinting and diversity studies. Molecular Ecology Resources, 8: 317-321.

Escudero A, Iriondo JM, Torres ME (2003) Spatial analysis of genetic diversity as a tool for plant conservation. Biological Conservation, 113: 351-365.

Esquinas-Alcazar $\mathbf{J}$ (2005) Protecting crop genetic diversity for food security: political, ethical and technical challenges. Nature Reviews Genetics, 6:946-953.

Estoup A, Jarne P, Cornuet J-M (2002) Homoplasy and mutation model at microsatellite loci and their consequences for population genetic analysis. Molecular Ecology, 11:1591-1604.

Evanno G, Regnaut S, Goudet J (2005) Detecting the number of clusters of individuals using the software STRUCTURE: a simulation study. Molecular Ecology, 14: 2611-2620. 
Excoffier L, Laval G, Schneider S (2005) Arlequin ver. 3.0: An integrated software package for population genetics data analysis. Evolutionary Bioinformatics Online, 1: 47-50.

Faostat (2014) FAO Statistics Database on the World Wide Web. http://faostat.fao.org/site/339/default.aspx) [accessed 10 May 2016].

Food and Agriculture Organization (FAO) (2007) Molecular markers - a tool for exploring genetic diversity. The state of the World's animal genetic resources for food and agriculture. Eds: Rischkowsky B, Pilling D. Food and Agriculture Organization, Rome, 359-379.

Food and Agriculture Organization (FAO) (nd) Biodiversity to nurture people. Available at http://www.fao.org/docrep/004/v1430e/V1430E04.htm [Accessed 10 May 2016].

Fries RE (1959) Annonaceae. Die natürlichen Pflanzenfamilien. Eds: Engler A, Prantl K. Ed. 2, Band 17 a II. Duncker \& Humblot, Berlin.

Foulley JL, Ollivier L (2006) Estimating allelic richness and its diversity. Livestock Science, 101: 150158.

Fourcade Y, Engler JO, Rödder D, Secondi J (2014) Mapping species distributions with MAXENT using a geographically biased sample of presence data: A performance assessment of methods for correcting sampling bias. PLoS One, 9: e97122.

Gajera HP, Bambharolia RP, Domadiya RK, Patel SV, Golakiya BA (2014) Molecular characterization and genetic variability studies associated with fruit quality of indigenous mango (Mangifera indica L.) cultivars. Plant Systematics and Evolution, 300:1011-1020.

Galán Sauco V, Herrero M, Hormaza JI (2014) Tropical and subtropical fruits. Horticulturae: Plants for People and Places. Eds: Dixon GR, Aldous DE. Springer, Dordrecht, Holland, 123-157.

Garcia-Ruiz MT, Mendoza-Castillo VM, Valadez-Moctezuma E, Muratalla-Lua A (2013) Initial assessment of natural diversity in Mexican fig landraces. Genetic and Molecular Research, 12: 39313943.

George AP, Broadley RH, Nissen RJ, Hamill SD (2002) Breeding new varieties of atemoya (Annona spp. hybrids). Acta Horticulturae, 575: 323-328.

Glenn TC (2011) Field guide to next-generation DNA sequencers. Molecular Ecology Resources, 11: 759-769.

Goodrich KR (2012) Floral scent in Annonaceae. Botanical Journal of the Linnean Society, 169: 262279.

Gottsberger G (1999) Pollination and evolution in neotropical Annonaceae. Plant Species Biology, 14: 143-152.

Gottsberger G (2012) How diverse are Annonaceae with regard to pollination? Botanical Journal of the Linnean Society, 169: 245-261. 
Guarino L, Jarvis A, Hijmans RJ, Maxted N (2002) Geographic information systems (GIS) and the conservation and use of plant genetic resources. Managing Plant Genetic Diversity. Eds: Engels JEA. CAB International, Wallingford, 387-404.

Guichoux E, Lagache L, Wagner S, Chaumeil P, Leger P, Lepais O, Lepoittevin C, Malausa T, Revardel E, Salin F, Petit, RJ (2011) Current trends in microsatellite genotyping. Molecular Ecology Resources 11, 591-611.

Guimarães PR Jr, Galetti M, Jordano P (2008) Seed dispersal anachronisms: Rethinking the fruits extinct megafauna ate. PLoS ONE, 3(3): e1745.

Guindon S, Gascuel O (2003) A simple, fast and accurate method to estimate large phylogenies by maximum-likelihood. Systematic Biology, 52: 696-704.

Guo L, Palumbo R, Zhang ZS, Wang GL, Tay D, Zhang DL, Shen X, Shu HR (2009) Target region amplification polymorphism (TRAP) for evaluating genetic diversity in Malus Mill. genus. HortScience, 44: 1117-1117.

Hammer K (2003) A paradigm shift in the discipline of plant genetic resources. Genetic Resources and Crop Evolution, 50: 3-10.

Hanner R (2009). Data standards for barcode records in INSDC (BRis). [WWW document] URL http://barcoding.si.edu/pdf/dwg_data_standards-final.pdf. [Accessed March 2015].

Hebert PD, Cywinska A, Ball SL, DeWaard JR (2003) Biological identifications through DNA barcodes. Proceedings of the Royal Society B-Biological Sciences, 270(1512): 313-321.

Hennig W (1950) Grundzüge einer Theorie der phylogenetischen Systematik. Deutscher Zentralverlag, Berlin.

Hey $\mathbf{J}$ (2001) The mind of species problem. Tends in Ecology and Evolution, 16(7): 326-329.

Hey $\mathbf{J}$ (2006) On the failure of modern species concepts. Trends in ecology and evolution, 21(8): 447445.

Hijmans RJ, van Etten J (2012) Raster: Geographic analysis and modeling with raster data. R package version 2.3-24. [WWW document] URL http://CRAN.R-project.org/package=raster. [accessed 29 March 2016].

Hijmans RJ, Phillips S, Leathwick J, Elith J (2011) Dismo: Species Distribution Modeling. R package version 1.0-12. [WWW document] URL http://CRAN.R-project.org/package=dismo. [accessed 29 March 2016].

Holderegger R, Wagner HH (2006) A brief guide to landscape genetics. Landscape Ecology, 21: $793-$ 796.

Holderegger R, Buehler D, Gugerli F, Manen S (2010) Landscape genetics of plants. Trends in plant science, 15(12): 675-683.

Hollingsworth PM (2011) Refining the DNA barcode for land plants. Proceedings of the National Academy of Sciences of the United States of America, 108: 19451-19452. 
Huang HW, Layne DR, Peterson RN (1997) Using isozyme polymorphisms for identifying and assessing genetic variation in cultivated pawpaw (Asimina triloba ( $L$ ) Dunal). Journal of the American Society for Horticultural Science, 122: 504-511.

Huang HW, Layne DR, Riemenschneider DE (1998) Genetic diversity and geographic differentiation in pawpaw (Asimina triloba $(L)$ Dunal) populations from nine states as revealed by allozyme analysis. Journal of the American Society for Horticultural Science 123: 635-641.

Huang H, Layne DR, Kubisiak TL (2000) RAPD inheritance and diversity in pawpaw (Asimina triloba). Journal of the American Society for Horticultural Science 125: 454-459.

Huang HW, Layne DR, Kubisiak TL (2003) Molecular characterization of cultivated pawpaw (Asimina triloba) using RAPD markers. Journal of the American Society for Horticultural Science, 128: 85-93.

Ikegami H, Nogata H, Hirashima K, Awamura M, Nakahara T (2009) Analysis of genetic diversity among European and Asian fig varieties (Ficus carica L.) using ISSR, RAPD, and SSR markers. Genetic Resources and Crop Evolution, 56: 201-209.

Janzen DH, Martin PS (1982) Neotropical anachronisms: the fruits the gomphotheres ate. Science, 215(1): 19-27.

Jarvis A, Yeaman S, Guarino L, Tohme J (2005) The role of geographic analysis in locating, understanding, and using plant genetic diversity. Methods in Enzymology, 395: 279-298.

Jeffreys AJ (1979) DNA sequence variants in the G gamma-, A gamma-, delta- and beta-globin genes of man. Cell, 18: 1-10.

Jing ZB, Ruan X, Wang R, Yang Y (2013a) Genetic diversity and relationships between and within persimmon (Diospyros L.) wild species and cultivated varieties by SRAP markers. Plant Systematics and Evolution, 299: 1485-1492.

Jing ZB, Cheng, Guo CH, Wang XP (2013b) Seed traits, nutrient elements and assessment of genetic diversity for almond (Amygdalus spp.) endangered to China as revealed using SRAP markers. Biochemical Systematics and Ecology, 49:51-57.

Jombart T (2008) adegenet: a $\mathrm{R}$ package for the multivariate analysis of genetic markers. Bioinformatics, 24: 1403-1405.

Jombart T, Ahmed I (2011) adegenet 1.3-1: new tools for the analysis of genome-wide SNP data. Bioinformatics, 27(21): 3070-1.

Kalia RK, Rai MK, Kalia S, Singh R, Dhawan AK (2011) Microsatellite markers: an overview of the recent progress in plants. Euphytica, 177: 309-334.

Katoh K, Misawa K, Kuma K, Miyata T (2002) MAFFT: a novel method for rapid multiple sequence alignment based on fast Fourier transform. Nucleic Acids Research, 30: 3059-3066.

Kim H, Terakami S, Nishitani C, Kurita K, Kanamori H, Katayose Y, Sawamura Y, Saito T, Yamamoto T (2012) Development of cultivar-specific DNA markers based on retrotransposon-based insertional polymorphism in Japanese pear. Breeding Science, 62:53-62. 
Kizirian D, Donnelly MA (2004) The criterion of reciprocal monophyly and classification of nested diversity at the species level. Molecular Phylogenetics and Evolution, 32: 1072-1076.

Koek-Noorman J (1987) Multidisciplinary approach to the systematics of neotropical Annonaceae. Annonaceae Newsletter, 6: 2-6.

Kress WJ, Erickson DL (2007) A two-locus global DNA barcode for land plants: the coding rbcL gene complements the non-coding trnH-psbA spacer region. PLoS ONE, 2(6): e508.

Kress WJ, Wurdack KJ, Zimmer EA, Weigt LA, Janzen DH (2005) Use of DNA barcodes to identify flowering plants. Proceedings of the National Academy of Sciences of the United States of America, 102: 8369-8374

Kuzmina M, Ivanova N (2011) Canadian Center for DNA Barcoding (CCDB) Protocols. Primers sets for plants and fungi [WWW document] URL http://www.dnabarcoding.ca/CCDB_DOCS/CCDB _PrimerSets-Plants.pdf [accesed May 2016]

Larranaga N, Hormaza JI (2015) DNA barcoding of perennial fruit tree species of agronomic interest in the genus Annona (Annonaceae). Frontiers in Plant Science, 6: 589.

Larson G, Piperno DR, Allaby RG, Purugganan MD, Andersson L, Arroyo-Kalin M, Barton L, Vigueira CC, Denham T, Dobney K, Doust AN, Gepts P, Gilbert MTP, Gremillion KJ, Lucas L, Lukens L, Marshall FB, Olsen KM, Pires JC, Richerson PJ, de Casas RR, Sanjur OI, Thomas MG, Fuller DQ (2014) Current perspectives and the future of domestication studies. Proceedings of the National Academy of Sciences of the United States of America, 111(17): 6139-6146.

Le Corre V, Kremer A (2003) Genetic variability at neutral markers, quantitative trait loci and trait in a subdivided population under selection. Genetics, 164: 1205-1219.

Leinemann L, Steiner W, Hosius B, Kuchma O, Arenhoevel W, Fussi B, Haase B, Kaetzel R, Rogge M, Finkeldey R (2013) Genetic variation of chloroplast and nuclear markers in natural populations of hazelnut (Corylus avellana L.) in Germany. Plant Systematics and Evolution, 299: 369378.

Lewis PO (2001) Phylogenetic systematics turns over a new leaf. Trends in Ecology \& Evolution, 16: 30-37.

Li TF, Liu JR, Xie YN, Wang QY, Meng FJ (2014a) Analysis of genetic diversity in Prunus mira Koehne ex Sargent populations using AFLP markers. Plant Systematics and Evolution, 300: 475-482.

Li D, Liu Y, Li X, Rao J, Yao X, Zhong C (2014b) Genetic diversity in kiwifruit polyploid complexes: insights into cultivar evaluation, conservation, and utilization. Tree Genetics \& Genomes, 10: 14511463.

Li M, Zhao Z, Miao X (2014c) Genetic diversity and relationships of apricot cultivars in North China revealed by ISSR and SRAP markers. Scientia Horticulturae, 173: 20-28.

Li X, Yang Y, Henry RJ, Rossetto M, Wang Y, Chen S (2015) Plant DNA barcoding: from gene to genome. Biological Reviews, 90: 157-166. 
Liaw CC, Wu TY, Chang FR, Wu YC (2011) Historic perspectives on annonaceous acetogenins from the chemical bench to preclinical trials. Planta Medica, 76: 1390-1404.

Lin BB (2011) Resilience in agriculture through crop diversification: adaptive management for environmental change. Bioscience, 61(3):183-193.

Linnaeus C (1737) Hortus Cliffortianus, Amsterdam.

Liu C, Berry PM, Dawson TP, Pearson RG (2005) Selecting thresholds of occurrence in the prediction of species distributions. Ecography, 28: 385-393.

Lo EYY, Donoghue MJ (2012) Expanded phylogenetic and dating analyses of the apples and their relatives (Pyreae, Rosaceae). Molecular Phylogenetics and Evolution, 63: 230-243.

Lora J, Hormaza JI, Herrero M (2010) The progamic phase of an early-divergent angiosperm, Annona cherimola (Annonaceae). Annals of Botany, 105(2): 221-31.

Lora J, Herrero M, Hormaza JI (2011a) Stigmatic receptivity in a dichogamous early-divergent angiosperm species, Annona cherimola (Annonaceae): influence of temperature and humidity. American Journal of Botany, 98(2): 265-74.

Lora J, Hormaza JI, Herrero M, Gasser CS (2011b) Seedless fruits and the disruption of a conserved genetic pathway in angiosperm ovule development. Proceedings of the National Academy of Sciences of the United States of America, 108(13): 5461-5465.

Luo C, He X, Chen H, Ou S, Gao M, Brown JS, Tondo CT, Schnell RJ (2011) Genetic diversity of mango cultivars estimated using SCoT and ISSR markers. Biochemical Systematics and Ecology, 39: 676-68.

Maas PJM, Westra LYT (1985a) Studies in Annonaceae II: A monograph of the genus Anaxagorea. Part 1. Botanische Jahrbücher fur Systematik, Pflanzengeschichte und Pflanzengeographie, (1): 73134.

Maas PJM, Westra LYT (1985b) Studies in Annonaceae II: A monograph of the genus Anaxagorea. Part 2. Botanische Jahrbücher fur Systematik, Pflanzengeschichte und Pflanzengeographie, 105: 145204.

Maas PJM, Westra LYT, Rainer H, Lobão AQ, Erkens RHJ (2011) An updated index to genera, species, and infraspecific taxa of Neotropical Annonaceae. Nordic Journal of Botany, 29: 257-356.

Maddison WP, Maddison RD (2014) Mesquite: a modular system for evolutionary analysis. Version 3.01 (http://mesquiteproject.org).

Madhou M, Normand F, Bahorun T, Hormaza JI (2013) Fingerprinting and analysis of genetic diversity of litchi (Litchi chinensis Sonn.) accessions from different germplasm collections using microsatellite markers. Tree Genetics \& Genomes, 9: 387-396.

Manel S, Holderegger R (2013) Ten years of landscape genetics. Trends in Ecology \& Evolution, 28: 614-621. 
Manel S, Schwartz MK, Luikart G, Taberlet P (2003) Landscape genetics: combining landscape ecology and population genetics. Trends in Ecology \& Evolution, 18: 189-197.

Mansour E, Ben Khaled A, Triki T, Abid M, Bachar K, Ferchichi A (2015) Evaluation of genetic diversity among South Tunisian pomegranate (Punica granatum L.) accessions using fruit traits and RAPD markers. Journal of Agricultural Science and Technology, 17: 109-119.

Marcos JG (2005) Los pueblos navegantes del Ecuador Prehispánico. Abya-Yala, Quito, Ecuador, $137-170$

Martin C (2013) Desarrollo de un mapa genético, variación de ploidía y anomalías meióticas en el género Annona. Tesis doctoral, Universidad de Málaga.

Martin C, Herrero M, Hormaza JI (2011) Molecular characterization of apricot germplasm from an old stone collection. PLoS One 6(8): e23979.

Martin M, Mattioni C, Molina JR, Alvarez JB, Cherubini M, Herrera MA, Villani F, Martin LM (2012) Landscape genetic structure of chestnut (Castanea sativa Mill.) in Spain. Tree Genetics and Genomes, 8:127-136.

Matsuoka Y, Vigouroux Y, Goodman MM, Sanchez GJ, Buckler E, Doebley J (2002) A single domestication for maize shown by multilocus microsatellite genotyping. Proceedings of the National Academy of Sciences of the United States of America, 99: 6080-6084.

Mayr E (1942) Systematics and the origin of species. Columbia University Press, New York.

McClure KA, Sawler J, Gardner KM, Money D, Myles S (2014) Genomics: A potential panacea for the perennial problem. American Journal of Botany, 101: 1780-1790.

Meirmans PG, Hedrick PW (2011) Assessing population structure: FST and related measures. Molecular Ecology Resources, 11: 5-18.

Meyer CP, Paulay G (2005) DNA barcoding: error rates based on comprehensive sampling. PLoS Biology, 3: e422.

Meyer RS, DuVal AE, Jensen HR (2012) Patterns and processes in crop domestication: an historical review and quantitative analysis of 203 global food crops. New Phytologist, 196: 29-48.

Michalakis Y, Excoffier L (1996) A generic estimation of population subdivision using distances between alleles with special reference to microsatellite loci. Genetics, 142: 1061-1064.

Miller A, Schaal B (2005) Domestication of a Mesoamerican cultivated fruit tree, Spondias purpurea. Proceedings of the National Academy of Sciences of the United States of America, 15(12): 675-683.

Miller MA, Pfeiffer W, Schwartz T (2010) Creating the CIPRES Science Gateway for inference of large phylogenetic trees. Proceedings of the Gateway Computing Environments Workshop (GCE). New Orleans, LA, 1 - 8.

Mols JB, Gravendeel B, Chatrou LW, Pirie MD, Bygrave PC, Chase MW, Kessler PJA (2004) Identifying clades in Asian Annonaceae: Monophyletic genera in the polyphyletic Miliuseae. American Journal of Botany, 91: 590-600. 
Mondini L, Noorani A, Pagnotta MA (2009) Assessing plant genetic diversity by molecular tools. Diversity, 1: 19-35.

Morgado RR (2007) Mesoamérica: concepto y realidad de un espacio cultural. Arqueoweb: Revista sobre Arqueología en Internet, 8(2).

Morton JF (1987) Fruits of Warm Climates. Creative Resources Systems, Winterville, NC, USA.

Mullis K, Faloona F, Scharf S, Saiki R, Horn G, Erlich H (1986) Specific enzymatic amplification of DNA in vitro: The polymerase chain reaction. Cold Spring Harbor Symposia on Quantitative Biology, 51: 263-273.

Museo de la Nación (1995) Culturas precolombinas. Lima, Perú.

Nair AS, Teo CH, Schwarzacher T, Harrison PH (2005) Genome classification of banana cultivars from South India using IRAP markers. Euphytica, 144: 285-290.

National Research Council Panel on Lost Crops of the Incas (1990) Lost crop of the Incas. Arnoldia, 50(4): 2-15.

Neaves LE, Whitlock R, Piertney SB, Burke T, Butlin RK, Hollingsworth PM (2013) 15. Implications of climate change for genetic diversity and evolvability in the UK. Terrestrial biodiversity climate change impacts report card technical paper.

Nei M (1973) Analysis of gene diversity in subdivided populations. Proceedings of the National Academy of Sciences of the United States of America, 70: 3321-3323.

Nicolas V, Schaeffer B, Missoup AD, Kennis J, Colyn M, Denys C, Tatard C, Cruaud C, Laredo C (2012) Assessment of three mitochondrial genes (16S, Cytb, CO1) for identifying species in the praomyini tribe (Rodentia: Muridae). PLoS ONE, 7: e36586.

Olmstead RG, Palmer JD (1994) Chloroplast DNA systematics: a review of methods and data analysis. American Journal of Botany, 81(9): 2015-1224.

Olmstead RG, Sweere JA (1994) Combining data in phylogenetic systematics- an empirical approach using three molecular data sets in the Solanaceae. Systematic Biology, 43: 467-481.

Osuna ES (2015) The Aztec, Maya, and Inca civilizations. Eds: Sudhansu Chokroverty, Michel Billiard. Sleep Medicine Springer, New York, 55-59.

Padulosi S, Hodgkin T, Williams JT, Haq N (2002) Underutilised crops: trends, challenges and opportunities in the 21st Century. Eds: Engels J, Rao VR, Jackson M. Managing plant genetic diversity. CAB International, Wallingford, UK, 323-338.

Palmer JD (1985) Chloroplast DNA and molecular phylogeny. Bioessays, 2: 263-266.

Pang XH, Liu C, Shi LC, Liu R, Liang D, Li H, Cherny SS, Chen SL (2012) Utility of the trnH-psbA intergenic spacer region and its combinations as plant DNA barcodes: A meta-analysis. PLoS One 7: e48833.

Parida SK, Kalia SK, Sunita K (2009) Informative genomic microsatellite markers for efficient genotyping applications in sugarcane. Theoretical and Applied Genetics, 118: 327-38. 
Pascual L, Perfectti F, Gutierrez M, Vargas AM (1993) Characterizing isozymes of Spanish cherimoya cultivars. HortScience, 28: 845-847.

Passos MAN, de Oliveira Cruz V, Emediato FL, de Camargo Teixeira C, Souza MT, Matsumoto T, Renno Azevedo VC, Ferreira CF, Amorim EP, de Alencar Figueiredo LF, Martins NF, de Jesus Barbosa Cavalcante M, Baurens FC, da Silva OB Jr, Pappas GJ Jr, Pignolet L, Abadie C, Ciampi AY, Piffanelli P, Miller RN (2012) Development of expressed sequence tag and expressed sequence tag-simple sequence repeat marker resources for Musa acuminata. AoB Plants, 2012: pls030.

Pereira MF, Bandeira LF, Blanco AJ, Ciampi AY, Coelho AS (2008a) Development of microsatellite markers in Annona crassiflora Mart., a Brazilian Cerrado fruit tree species. Molecular Ecology Resources, 8: 1329-1331.

Pereira F, Carneiro J, Amorim A (2008b). Identification of species with DNA-based technology: current progress and challenges. Recent patents on DNA \& Gene Sequences Journal, 2(3): 187-199.

Pérez de Oteyza MA, Farré-Massip JM, Hermoso-González JM, Ruiz-Nieto A (1999) El banco español de germoplasma de chirimoyo. Parámetros estudiados y su variabilidad. Actas de Horticultura, 25: 7-12.

Perfectti F, Pascual L (1996) Segregation distortion of isozyme loci in cherimoya (Annona cherimola Mill). Theoretical and Applied Genetics, 93: 440-446.

Perfectti F, Pascual L (1998a) Characterization of cherimoya germplasm by isozyme markers. Fruit Varieties Journal, 52: 53-62.

Perfectti F, Pascual L (1998b) Genetic linkage of isozyme loci in Annona cherimola. Hereditas, 128: 87-90.

Perfectti F, Pascual L (2004) Geographic variation for isozymes in cherimoya (Annona cherimola Mill.). Genetic Resources and Crop Evolution, 51: 837-843.

Perfectti F, Pascual L (2005) Genetic diversity in a worldwide collection of cherimoya cultivars. Genetic Resources and Crop Evolution, 52: 959-966.

Perry L, Dickau R, Zarrillo S, Holst I, Pearsall DM, Piperno DR, Berman MJ, Cooke RG, Rademaker K, Ranere AJ, Raymond JS (2007) Starch fossils and the domestication and dispersal of chili peppers (Capsicum spp. L.) in the Americas. Science, 315 (5814): 986-988.

Phillips SJ, Anderson RP, Schapire RE (2006) Maximum entropy modeling of species geographic distributions. Ecological Modelling, 190: 231-259.

Pickersgill B (2007) Domestication of Plants in the Americas: Insights from Mendelian and Molecular Genetics. Annals of Botany, 100: 925-940.

Pinto AC, Cordeiro MCR, Andrade SRM, Ferreira FR, Filgueiras HA, Alves RE, Kinpara DJ (2005) Annona Species. International Centre for Underutilised Crops, University of Southampton, Southampton.

Pirie MD, Chatrou LW, Erkens RHJ, Maas JW, van der Niet T, Mols JB, Richardson JE (2005) Phylogeny reconstruction and molecular dating in four Neotropical genera of Annonaceae: the effect of 
taxon sampling in age estimations. Eds: Bakker FT, Chatrou LW, Gravendeel B, Pelser PB. Plant species-level systematics: new perspectives on pattern \& process. Regnum Vegetabile 143. A. R. G. Gantner Verlag, Vaduz, Liechtenstein, 149-174.

Pirie MD, Balcázar Vargas MP, Botermans M, Bakker FT, Chatrou LW (2007) Ancient paralogy in the cpDNA trnL-F region in Annonaceae: implications for plant molecular systematics. American Journal of Botany, 94: 1003-1016.

Pollegioni P, Woeste KE, Chiocchini F, Olimpieri I, Tortolano V, Clark J, Hemery GE, Mapelli S, Malvolti ME (2014) Landscape genetics of Persian walnut (Juglans regia L.) across its Asian range. Tree Genetics \& Genomes, 10: 1027-1043.

Pomper KW, Crabtree SB, Brown SP, Jones SC, Bonney TM, Layne DR (2003) Assessment of genetic diversity of pawpaw (Asimina triloba) cultivars with intersimple sequence repeat markers. Journal of the American Society for Horticultural Science, 128: 521-525.

Popenoe W (1921) The native home of the cherimoya. Journal of Heredity, 12: 331-336.

Popenoe H, King SR, Leon J, Kalinowski LS, Vietmeyer ND, Dafforn M (1989) Lost crops of the Incas. Little-known plant of the Andes with promise for worldwide cultivation. National Academy Press, Washington, D.C.

Porth I, El-Kassaby YA (2014) Assessment of the genetic diversity in forest tree populations using molecular markers. Diversity, 6: 283-295.

Pozorski T, Pozorski S (1997) Cherimoya and guanabana in the archaeological record of Peru. Journal of Ethnobiology 17(2): 235-248.

Pritchard JK, Stephens M, Donnelly P (2000) Inference of population structure using multilocus genotype data. Genetics, 155: 945-959.

Pritchard JK, Wen X, Falush D (2010) Documentation for structure software: version2.3 [WWW document] URL http://pritchardlab.stanford.edu/structure_software/release_versions/v2.3.4/structure _doc.pdf [accessed 29 March 2016].

Quan X, Zhou SL (2011) Molecular identification of species in Prunus sect. Persica (Rosaceae), with emphasis on evaluation of candidate barcodes for plants. Journal of Systematics and Evolution, 49: 138-145.

Rahman M, Yamada M, Yoshida M (1997) Relationship of Annona species as revealed by PCRRPLP analysis. Breeding Science, 47: 335-339.

Rahman MSM, Shimada T, Yamamoto T, Yonemoto JY, Yoshida M (1998) Genetical diversity of cherimoya cultivars revealed by amplified fragment length polymorphism (AFLP) analysis. Breeding science, 48: 5-10.

Rainer H (2007) Monographic studies in the genus Annona L. (Annonaceae): inclusion of the genus Rollinia A.St.-Hil. Annalen des Naturhistorischen Museums in Wien. Serie B, Botanik und Zoologie Vienna, 108: 191-205. 
Rainer H, Chatrou LW (eds) (2016) AnnonBase: Annonaceae GSD (version Jan 2014). In: Species 2000 \& ITIS Catalogue of Life, 26th August 2016. Eds: Roskov Y, Abucay L, Orrell T, Nicolson D., Kunze T, Flann C, Bailly N, Kirk P, Bourgoin T, DeWalt RE, Decock W, De Wever A. Digital resource at www.catalogueoflife.org/col. Species 2000: Naturalis, Leiden, the Netherlands

Raji R, Jannatizadeh A, Fattahi R, Esfahlani MA (2014) Investigation of variability of apricot (Prunus armeniaca L.) using morphological traits and microsatellite markers. Scientia Horticulturae, 176: 225231.

Ramanatha Rao V, Hodgkin T (2002) Genetic diversity and conservation and utilization of plant genetic resources. Plant Cell, Tissue and Organ Culture, 68: 1-19.

Ratnasingham S, Hebert PDN (2007) BOLD: the barcode of life data system (www.barcodinglife.org). Molecular Ecology Notes, 7: 355-364.

Richardson JE, Chatrou LW, Mols JB, Erkens RHJ, Pirie MD (2004) Historical biogeography of two cosmopolitan families of flowering plants: Annonaceae and Rhamnaceae. Philosophical Transactions of the Royal Society of London Series B-Biological Sciences, 359: 1495-1508.

Ronning C, Schnell R, Gazit S (1995) Using randomly amplified polymorphic DNA (RAPD) markers to identify Annona cultivars. Journal of the American Society for Horticultural Science, 120: 726-729.

Rosell P, Galán-Saúco V, Hernández PM (1997) Cultivo del chirimoyo en Canarias. Cuadernos de divulgación. Departamento de Fruticultura Tropical Instituto Canario de Investigaciones Agradas. ICIA. Gobierno de canarias consejería de agricultura, ganadería, pesca y alimentación. España.

Rosen DE (1979) Fishes from the upland and intermontane basins of Guatemala: revisionary studies and comparative geography. Bulletin American Museum of Natural History, 162: 267-376.

Rosenberg NA (2004) DISTRUCT: a program for the graphical display of population structure. Molecular Ecology Notes, 4: 137-138.

Roy S, Tyagi A, Shukla V, Kumar A, Singh UM, Chaudhary LB, Datt B, Bag SK, Singh PK, Nair NK, Husain T, Tuli R (2010) Universal plant DNA barcode loci may not work in complex groups: a case study with Indian Berberis species. PLoS One, 5: e13674.

Sabir JSM, Abo-Aba S, Bafeel S, Zari TA, Edris S, Shokry AM, Atef A, Gadalla NO, Ramadan AM, Al-Kordy MA, El-Domyati FM, Jansen RK, Bahieldin A (2014) Characterization of ten date palm (Phoenix dactylifera L.) cultivars from Saudi Arabia using AFLP and ISSR markers. Comptes Rendus Biologies, 337:6-18.

Saitou N (1996) Reconstruction of gene trees from sequence data. Methods in Enzymology, 266: 427449.

Safford WE (1914) Classification of the genus Annona, with descriptions of new and imperfectly known species. Contributions from the United States National Herbarium, 18(1): 1-68.

Samal KC, Jena RC, Swain SS, Das BK, Chand PK (2012) Evaluation of genetic diversity among commercial cultivars, hybrids and local mango (Mangifera indica L.) genotypes of India using cumulative RAPD and ISSR markers. Euphytica, 185: 195-213. 
Samuel AF, Drucker AG, Andersena SB, Simianer H, van Zonneveld M (2013) Development of a cost-effective diversity-maximising decision-support tool for in situ crop genetic resources conservation: The case of cacao. Ecological Economics, 96: 155-164.

Saunders RMK (2012) The diversity and evolution of pollination systems in Annonaceae. Botanical Journal of the Linnean Society, 169: 222-244.

Sboner A, Mu XJ, Greenbaum D, Auerbach RK, Gerstein MB (2011) The real cost of sequencing: higher than you think! Genome Biology, 12: 125.

Scharaschkin T, Doyle JA (2005) Phylogeny and historical biogeography of Anaxagorea (Annonaceae) using morphology and non-coding chloroplast DNA sequence data. Systematic Botany, 30: 712-735.

Schatz GE (1992) Taxonomic notes on Mesoamerican Annona section Atta (Annonaceae), including Annona pruinosa sp. Nov. Novon, 2: 249-251.

Scheldeman X (2002) Distribution and potential of cherimoya (Annona cherimola Mill.) and highlands papayas (Vasconcellea spp.) in Ecuador. Faculteit Landbouwkundige en Toegepaste Biologische Wetenschappen. Universidad de Gante, Holanda.

Scheldeman X, van Zonneveld M (2012) Training Manual on Spatial Analysis of Plant Diversity and Distribution. Bioversity International, Rome.

Scheldeman X, Van Damme P, Ureña Alvarez JV, Romero Motoche JP (2003) Horticultural potential of Andean fruit crops exploring their centre of origin. Acta Horticulturae, 598: 97-102.

Schwartz MK, Mills LS, McKelvey KS, Ruggiero LF, Allendorf FW (2002) DNA reveals high dispersal synchronizing the population dynamics of Canada lynx. Nature, 415: 520-522.

Sehic J, Garkava-Gustavsson L, Fernandez-Fernandez F, Nybom H (2012) Genetic diversity in a collection of European pear (Pyrus communis) cultivars determined with SSR markers chosen by ECPGR. Scientia Horticulturae, 145: 39-45.

Sharer R (2012) Who were the Maya? Expedition, 54(1): 12-16 [WWW document] URL www.penn.museum. [accesed 29 March 2016]

Shen Y, Ding X, Wang F, Cai B, Gao Z, Zhang Z (2011) Analysis of genetic diversity in Japanese apricot (Prunus mume Sieb. et Zucc.) based on REMAP and IRAP molecular markers. Scientia Horticulturae, 132: 50-58.

Shi S, Li JL, Sun JH, Yu J, Zhou SL (2013) Phylogeny and Classification of Prunus sensu lato (Rosaceae). Journal of Integrative Plant Biology, 55: 1069-1079.

Shrestha UB, Bawa KS (2014) Impact of climate change on potential distribution of chinese caterpillar fungus (Ophiocordyceps sinensis) in Nepal Himalaya. PLoS One, 9: e106405.

Slatkin M (1995) A measure of population subdivision based on microsatellite allele frequencies. Genetics, 139: 457-462. 
Slatkin M, Takahata N (1985) The average frequency of private alleles in a partially isolated population. Theoretical Population Biology, 28: 314-331.

Sokal RR \& Crovello TJ (1970) The biological species concept: a critical evaluation. American Naturalist, 104, 127-153.

Soltis DE, Soltis PS, Endress PK, Chase MW (2005) Angiosperm phylogeny and evolution. Sinauer Associates, Sunderland.

Srivathsan A, Meier R (2012) On the inappropriate use of Kimura-2-parameter (K2P) divergences in the DNA-barcoding literature. Cladistics, 28: 190-194.

Stevens PF (2001 onwards) Angiosperm Phylogeny Website. Version 12, July 2012 [www document] URL http://www.mobot.org/MOBOT/research/APweb/ [accesed March 2016].

Storfer A, Murphy MA, Evans JS, Goldberg CS, Robinson S, Spear SF, Dezzani R, Delmelle E, Vierling L, Waits LP (2007) Putting the 'landscape' in landscape genetics. Heredity, 98: 128-142.

Storfer A, Murphy MA, Spear SF, Holderegger R, Waits LP (2010) Landscape genetics: where are we now? Molecular Ecology 19:3496-3514.

Su YC, Saunders RM (2006) Monograph of Pseuduvaria (Annonaceae). Monographs in Systematic Botany, 79: 1-204.

Su YCF, Saunders RMK (2009) Evolutionary divergence times in the Annonaceae: evidence of a late Miocene origin of Pseuduvaria in Sundaland with subsequent diversification in New Guinea. BMC Evolutionary Biology, 9.

Su YC, Chaowasku T, Saunders RM (2010) An extended phylogeny of Pseuduvaria (Annonaceae) with descriptions of three new species and a reassessment of the generic status of Oreomitra. Systematic Botany 35, 1, 30-39.

Sunil N, Sivaraj N, Anitha K, Abraham B, Kumar V, Sudhir E, Vanaja M, Varaprasad KS (2009) Analysis of diversity and distribution of Jatropha curcas L. germplasm using Geographic Information System (DIVA-GIS). Genetic resources and crop evolution, 56:115-119.

Swofford DL, Olsen GJ, Waddell PJ \& Hillis DM (1996) Phylogenetic inference. Molecular Systematics. Eds: Hiillis DM, Moritz D, Mable BK. Sinauer Associates, Sunderland, 407-514.

Syed NH, Sureshsundar S, Wilkinson MJ, Bhau BS, Cavalcanti JJV, Flavell AJ (2005) Ty1-copia retrotransposon-based SSAP marker development in cashew (Anacardium occidentale L.). Theoretical and Applied Genetics, 110:1195-1202.

Szpiech ZA, Rosenberg NA (2011) On the size distribution of private microsatellite alleles. Theoretical Population Biology, 80: 100-113.

Szpiech ZA, Jakobsson M, Rosenberg NA (2008) ADZE: A rarefaction approach for counting alleles private to combinations of populations. Bioinformatics, 24(21): 2498-2504.

Taberlet P, Gielly L, Pautou G, and Bouvet J (1991) Universal primers for amplification of three noncoding regions of chloroplast DNA. Plant Molecular Biology, 17: 1105-1109. 
Takrouni MM, Ali IB, Messaoued C, Boussaid M (2012) Genetic variability of Tunisian wild strawberry tree (Arbutus unedo L.) populations interfered from isozyme markers. Scientia Horticulturae, 146: $92-98$

Tamura K, Peterson D, Peterson N, Stecher G, Nei M, Kumar S (2011) MEGA5: molecular evolutionary genetics analysis using maximum likelihood, evolutionary distance, and maximum parsimony methods. Molecular Biology and Evolution, 28; 2731-2739.

Tamura K, Stecher G, Peterson D, Filipski A, Kumar S (2013) MEGA6: Molecular Evolutionary Genetics Analysis version 6.0. Molecular Biology and Evolution, 30: 2725-2729.

Taylor HR, Harris WE (2012) An emergent science on the brink of irrelevance: a review of the past 8 years of DNA barcoding. Molecular Ecology Resources, 12 (3): 377-388.

Thakur D, Singh R (1965) Studies on pollen morphology, pollination and fruit set in some Annonas. Indian Journal of Horticulture 22: 10-18.

Thomas E, van Zonneveld M, Loo J, Hodgkin T, Galluzzi G, van Etten J (2012a) Present spatial diversity patterns of Theobroma cacao L. in the neotropics reflect genetic differentiation in Pleistocene refugia followed by human-influenced dispersal. PLoS One, 7: e47676.

Thomas DC, Surveswaran S, Xue B, Sankowsky G, Mols, JB, Keler PJA, Saunders RMK (2012b) Molecular phylogenetics and historical biogeography of the Meiogyne-Fitzalania clade (Annonaceae): Generic paraphyly and late Miocene-Pliocene diversification in Australasia and the Pacific. Taxon, 61: 559-575.

Towle MA (1961) The ethnobotany of precolumbian Peru. Aldine Publishing Co, Chicago.

Uchoi A, Malik SK, Choudhary R, Kumar S, Rohini MR, Pal D1, Ercisli S, Chaudhury R (2016) Inferring phylogenetic relationships of Indian citron (Citrus medica L.) based on rbcL and matK sequences of chloroplast DNA. Biochemical Genetics, 54(3): 249-69.

United Nations Environment Programme (UNEP) (2007) Chapter 5: Biodiversity. Global Environment Outlook (GEO 4): Environment for Development. United Nations Environment Programme. Nairobi. [WWW document] URL http://www.unep.org/geo/geo4/report/geo4_report_full_en.pdf [Accesed 10 May 2016].

Urbanek S (2013) rJava: Low-level R to Java interface. R package version 0.9-6. [WWW document] URL http://CRAN.R-project.org/package=rJava. [accessed 29 March 2016].

van Etten J (2011) gdistance: distances and routes on geographical grids. R package version 1.1-2. [WWW document] URL http://CRAN.R-project.org/package=gdistance [accessed 29 March 2016].

van Etten J (2015) gdistance: Distances and Routes on Geographical Grids. R package version 1.1-7. [WWW document] URL http://CRAN.R-project.org/package=gdistance [accessed 29 March 2016].

van Damme P, van Damme V, Scheldeman X (2000) Ecology and cropping of cherimoya (Annona cherimola Mill.) in Latin America. New data from Ecuador. Fruits, 55; 195-206.

van Hintum T, Brown AHD, Spillane C, Hodgkin T (2000) Core collections of plant genetic resources. IPGRI Technical Bulletin No.3. International Plant Genetic Resources Institute, Rome. 
Vanhove W, van Damme P (2013) Value chains of cherimoya (Annona cherimola Mill.) in a centre of diversity and its on-farm conservation implications. Tropical Conservation Science, 6: 158-180.

van Velzen R, Weitschek E, Felici G, Bakker FT (2012) DNA barcoding of recently diverged species: relative performance of matching methods. PLoS ONE 7: e30490.

van Zonneveld M, Scheldeman X, Escribano P, Viruel MA, Van Damme P, Garcia W, Tapia C, Romero J, Siguenas M, Hormaza Jl (2012) Mapping genetic diversity of cherimoya (Annona cherimola Mill.): application of spatial analysis for conservation and use of plant genetic resources. PLoS One 7: e29845.

van Zuilen CM (1996). Patterns and affinities in the Duguetia alliance (Annonaceae): molecular and morphological studies. PhD. Dissertation, Utrecht University, Utrecht, Netherlands.

Vigouroux Y, Glaubitz JC, Matsuoka Y, Goodman MM, Sánchez GJ, Doebley J (2008) Population structure and genetic diversity of New World maize races assessed by DNA microsatellites. American Journal of Botany, 95(10): 1240-1253.

Viruel MA, Hormaza JI (2004) Development, characterization and variability analysis of microsatellites in lychee (Litchi chinensis Sonn., Sapindaceae). Theoretical and Applied Genetics, 108: 896-902.

Volk GM, Henk AD, Baldo A, Fazio G, Chao CT, Richards CM (2015) Chloroplast heterogeneity and historical admixture within the genus Malus. American Journal of Botany, 102(7): 1198-208.

Vos P, Hogers R, Bleeker M, Reijans M, van de Lee T, Hornes M, Fritjters A, Pot J, Peleman J, Kuiper M, Zabeau M (1995) AFLP: a new technique for DNA fingerprinting. Nucleic Acids Research, 23: 4407-4414.

Wagner I, Maurer WD, Lemmen P, Schmitt HP, Wagner M, Binder M, Patzak P (2014) Hybridization and genetic diversity in wild apple (Malus sylvestris (L.) Mill) from various regions in Germany and from Luxembourg. Silvae Genetica, 63: 81-94.

Walker JW (1972) Chromosome numbers, phylogeny, phytogeography of the Annonaceae and their bearing on the (original) basic chromosome number of Angiosperms. Taxon, 21(1): 57-65.

Wang Y, Reighard GL, Layne DR, Abbott AG, Huang HW (2005) Inheritance of AFLP markers and their use for genetic diversity analysis in wild and domesticated pawpaw (Asimina triloba (L.) Dunal). Journal of the American Society for Horticultural Science, 130: 561-568.

Wayne GP (2013) The beginner's guide to representative concentration pathways, Version 1.0. [WWW document] URL http://www.skepticalscience.com/docs/RCP_Guide.pdf. [accessed 29 March 2016].

Weir BS, Cockerham CC (1984) Estimating F-statistics for the analysis of population structure. Evolution, 38: 1358-1370.

Wester PJ (1910) Pollination experiments with Anonas. Bulletin of the Torrey Botanical Club, 37: 529539.

White D, Gramacy RB (2012) Maptree: Mapping, pruning, and graphing tree models. R package version 1.4-7. [WWW document] URL http://CRAN.R-project.org/package=maptree. [accessed 29 March 2016]. 
Williams JGK, Kuberik AR, Livak KJ, Rafalski, JA, Tingey SV (1990) DNA polymorphisms amplified by arbitrary primers are useful as genetic markers. Nucleic Acids Research,18: 6531-6535.

Winter DJ (2012) mmod: an R library for the calculation of population differentiation statistics. Molecular Ecology Resources, 12(6): 1158-60.

Wolters B (2001) Dissemination of American economic plants on precolumbian sea routes by Amerindians. Migration \& Diffusion, 1: 40-58.

Wright S (1943) Isolation by Distance. Genetics, 28: 114-138.

Wünsch A, Hormaza JI (2002) Cultivar identification and genetic fingerprinting of temperate fruit tree species using DNA markers. Euphytica, 125: 59-67.

Yilmaz KU, Paydas-Kargi S, Dogan Y, Kafkas S (2012) Genetic diversity analysis based on ISSR, RAPD and SSR among Turkish apricot germplasms in Iran Caucasian eco-geographical group. Scientia Horticulturae, 138: 138-143.

Yukimoto S, Adachi Y, Hosaka M, Sakami T, Yoshimura H, Hirabara M, Tanaka TY, Shindo E, Tsujino H, Deushi M, Mizuta R, Yabu S, Obata A, Nakano H, Koshiro T, Ose T, Kitoh A (2012) A new global climate model of the Meteorological Research Institute: MRI-CGCM3-model description and basic performance. Journal of the Meteorological Society of Japan, 90A: 23-64.

Zanis MJ, Soltis DE, Soltis PS, Mathews S, Donoghue MJ (2002) The root of the angiosperms revisited. Proceedings of the National Academy of Sciences of the United States of America, 99: 68486853.

Zhang CY, Wang FY, Yan HF, Hao G, Hu CM, Ge XJ (2012) Testing DNA barcoding in closely related groups of Lysimachia L. (Myrsinaceae). Molecular Ecology Resources, 12: 98-108.

Zhang JQ, Meng SY, Wen J, Rao GY (2015) DNA Barcoding of Rhodiola (Crassulaceae): A case study on a group of recently diversified medicinal plants from the Qinghai-Tibetan Plateau. PLoS One, 10: e0119921.

Zill GE, Mahdeem H (1998) General observations on hybridizing Annona species. Selected Proceedings of the Florida State Horticultural Society, 111: 314-315.

Zohary D (2004) Unconscious selection and the evolution of domesticated plants. Economic Botany, 58: 5-10. 


\section{ANEXO 1}

Larranaga N, Hormaza Jl (2015) DNA barcoding of perennial fruit tree species of agronomic interest in the genus Annona (Annonaceae). Frontiers in Plant Science, 6:589. 


\title{
DNA barcoding of perennial fruit tree species of agronomic interest in the genus Annona (Annonaceae)
}

\author{
Nerea Larranaga and José l. Hormaza * \\ Instituto de Hortofruticultura Subtropical y Mediterránea La Mayora (IHSM-Universidad de Málaga, Consejo Superior de \\ Investigaciones Científicas), Málaga, Spain
}

\section{OPEN ACCESS}

Edited by:

Jaime Prohens,

Universitat Politècnica de València,

Spain

Reviewed by:

Hisayo Yamane,

Kyoto University, Japan

Nahla Victor Bassil,

U.S. Department of

Agriculture-Agricultural Research Service-National Clonal Germplasm Repository (USDA-ARS-NCGR), USA

*Correspondence: José l. Hormaza, Instituto de Hortofruticultura Subtropical y Mediterránea La Mayora (IHSM-Universidad de Málaga, Consejo Superior de Investigaciones Cientificas), 29750 Algarrobo-Costa, Málaga, Spain

ihormaza@eelm.csic.es

Specialty section:

This article was submitted to Crop Science and Horticulture, a section of the journal Frontiers in Plant Science

Received: 20 May 2015 Accepted: 16 July 2015

Published: 30 July 2015

Citation: Larranaga N and Hormaza Jl (2015) DNA barcoding of perennial fruit tree species of agronomic interest in the genus Annona (Annonaceae).

Front. Plant Sci. 6:589. doi: 10.3389/fpls.2015.00589
The DNA barcode initiative aims to establish a universal protocol using short genetic sequences to discriminate among animal and plant species. Although many markers have been proposed to become the barcode of plants, the Consortium for the Barcode of Life (CBOL) Plant Working Group recommended using as a core the combination of two portions of plastid coding region, rbcL and matK. In this paper, specific markers based on matK sequences were developed for 7 closely related Annona species of agronomic interest (Annona cherimola, A. reticulata, A. squamosa, A. muricata, A. macroprophyllata, A. glabra, and $A$. purpurea) and the discrimination power of both rbcL and matK was tested using also sequences of the genus Annona available in the Barcode of Life Database (BOLD) data systems. The specific sequences developed allowed the discrimination among all those species tested. Moreover, the primers generated were validated in six additional species of the genus (A. liebmanniana, A. longiflora, A. montana, A. senegalensis, A. emarginata and A. neosalicifolia) and in an interspecific hybrid ( $A$. cherimola $\times A$. squamosa). The development of a fast, reliable and economic approach for species identification in these underutilized subtropical fruit crops in a very initial state of domestication is of great importance in order to optimize genetic resource management.

Keywords: Annona, DNA barcoding, matK, rbcL, species identification

\section{Introduction}

Annona L. is the type genus among the approximately 110 included in the Annonaceae (Chatrou et al., 2012), an angiosperm family within the Magnoliales in the Magnoliid clade (APG, 2009). Due to its phylogenetic situation among the early-divergent angiosperms, this family has been subject of a considerable interest from taxonomic and evolutionary points of view. Different molecular markers based on both chloroplast and nuclear sequences have been used to infer phylogenetic relationships among species of the family. Among chloroplast sequences, rbcL, matK, ndhF, trnL, trnT-L, trnL-F, trnS-G, atpB-rbcL, psbA-trnH, ycf1, rpl32-trnL, or ndhF-rpl32 have been used in one or several studies (Richardson et al., 2004; Chatrou et al., 2012; Thomas et al., 2012; Chaowasku et al., 2014). Among nuclear markers, microsatellite flanking regions were used by Chatrou et al. (2009). Additional molecular markers have been developed in the Annona genus mainly for fingerprinting and genetic diversity studies; isozymes (Ellstrand and Lee, 1987; Pascual et al., 1993; Perfectti and Pascual, 1998, 2004, 2005), randomly amplified polymorphic DNA (RAPDs) (Ronning et al., 1995), amplified fragment length polymorphism (AFLPs) (Rahman et al., 1998) 
and, more recently, microsatellites (Escribano et al., 2004, 2007, 2008a,b; Pereira et al., 2008; van Zonneveld et al., 2012).

Several species of the genus Annona produce edible fruits and have been cultivated and used as a food source by preColumbian cultures in Central and South America (Popenoe, 1989). Cultivation has continued to the present day and some of them now are incipient but prosperous crops in several developing countries with tropical and subtropical climates: cherimoya (Annona cherimola Mill.), sugar apple (A. squamosa L.), atemoya (Annona x atemoya Mabb., a hybrid between $A$. cherimola and A. squamosa), guanabana or soursop (A. muricata L.), custard apple (A. reticulata L.), ilama (A. macroprophyllata Donn. Sm.), pond-apple (A. glabra L.) or soncoya (A. purpurea Moc. \& Sessé ex Dunal). All of them are native of the Neotropics and only $A$. cherimola is adapted to subtropical climates in higher elevations of Central and South America (from 1000 to $2500 \mathrm{~m}$ ). Among those, cherimoya, sugar apple, guanabana, and atemoya show some commercial importance in various tropical and subtropical regions whereas the other species are generally used only locally with very limited or nonexistent production at a commercial scale. Production data are difficult to find for those species with perhaps the exception of cherimoya which value chains in South American countries have been recently studied (Vanhove and van Damme, 2013). The presence of interspecific hybrids and the lack of flowers and fruits during most of the year make rapid unequivocal identification of these species difficult in the field, hindering studies in different areas such as diversity evaluation and germplasm collection, conservation and management. Consequently a fast and reliable molecular method for identification of closely related species of Annona will be an important advance in those kinds of studies.

One of the best approaches to unequivocally identify species from leaf samples collected in the field is the use of DNA barcoding techniques. DNA barcoding aims to the adoption, in a great scale, of a few short standardized genome portions that allows a complete species identification and discrimination, especially in cases where morphological identification is difficult. In 2004 the international initiative Consortium for the Barcode of Life (CBOL) was founded for the development of a global method for the identification of plant and animal species. Six years later, the International Barcode of Life (iBOL) was activated for the maintenance of the barcode reference library BOLD (Barcode of Life Data systems) (Ratnasingham and Hebert, 2007; Bhargava and Sharma, 2013). Since Hebert et al. (2003) proposed the mitochondrial gene cytochrome $c$ oxidase 1 (CO1) as the barcode for animal species, it has been widely used (Hebert et al., 2003; Nicolas et al., 2012). In the case of plants, the CBOL Plant Working Group recommended a two locus combination of the chloroplast ribulose-1, 5-bisphosphate carboxylase/oxygenase large subunit gene $(r b c L)$ and maturase K gene (matK) as the core barcode (CBOL Plant Working Group, 2009). However, in some cases those two markers produce incomplete species resolution, especially in closely related taxa (Zhang et al., 2012) or recently diverged species (van Velzen et al., 2012). Consequently, the use of additional genome portions such as the internal transcribed spacer (ITS) and the second internal transcribed spacer (ITS2) from nuclear ribosomal DNA or the chloroplast $p s b A-t r n H$ intergenic spacer have been proposed (Kress et al., 2005; Chen et al., 2010; China Plant BOL Group et al., 2011; Hollingsworth, 2011; Pang et al., 2012). In addition, the complete chloroplast genome is increasingly being used as super-barcode due to its species discrimination power, resolving some problems derived from the single or multiple loci barcode techniques ( $\mathrm{Li}$ et al., 2015).

In order to have a fast and reliable method to discern between closely related Annona species with agronomic interest, in this work we developed species specific primers to unequivocally differentiate the seven most common agronomically interesting Annona species present in Central and South America (Annona cherimola, A. reticulata, A. squamosa, A. muricata, A. macroprophyllata, A. glabra and A. purpurea) based on newly sequenced data. The sequences were validated in 6 additional species of Annona and in an interspecific hybrid. The discrimination power of the most used plant barcode genes (rbcL and matK) was tested, using also additional Annona sequences available in the BOLD database and new sequences obtained were registered in the GenBank data base web page.

\section{Materials and Methods}

\section{Plant Material}

Leaves from three different genotypes of each of seven Annona species (Annona cherimola, A. reticulata, A. squamosa, A. muricata, A. macroprophyllata, A. glabra, and A. purpurea) were sampled in order to detect intraspecific variability. The materials were either collected from the wild or from an ex situ Annona germplasm collection maintained at the IHSM la Mayora in Málaga (Spain) at latitude $36^{\circ} 45^{\prime} \mathrm{N}$, longitude $4^{\circ} 4^{\prime} \mathrm{W}$ and altitude $35 \mathrm{~m}$ above sea level. Their geographic origin and codes are described in Table 1. All trees were previously identified in the field using morphological characters. Leaf samples from 6 additional Annona species (A. liebmanniana Baill., A. longiflora S. Watson, A. montana Macfad., A. senegalensis Pers., A. emarginata (Schltdl.) H. Rainer, and A. neosalicifolia H. Rainer.) and 5 atemoya hybrids ( $A$. cherimola $\mathrm{x} A$. squamosa), were used in order to test the validity of the primers generated (Table 1).

\section{DNA Extraction, PCR Amplification, Visualization and Sequencing}

Plant DNA extraction was performed from $50 \mathrm{mg}$ of young leaf tissue by a modified CTAB method (Viruel and Hormaza, 2004). Each PCR reaction contained $16 \mathrm{mM}\left(\mathrm{NH}_{4}\right)_{2} \mathrm{SO}_{4}, 67 \mathrm{mM}$ Tris-ClH pH 8.8, $0.01 \%$ Tween-20, $3 \mathrm{mM} \mathrm{MgCl}_{2}, 0.1 \mathrm{mM}$ each dNTP, $0.3 \mu \mathrm{M}$ each primer, $20 \mathrm{ng}$ genomic DNA and 1 unit of BioTaq ${ }^{\mathrm{TM}}$ DNA polymerase (Bioline, London, UK) in a final volume of $15 \mu \mathrm{l}$. For sequencing the final volume was increased to $35 \mu \mathrm{l}$ maintaining the concentration of the different ingredients. Universal primers and PCR protocols used to amplify rbcL and matK genes were those proposed by the Plant Working Group of the Consortium for the Barcode of Life (www.barcoding.si.edu/plant_working_group.html). Primers developed in this work are described in Table 2. PCRs were 
TABLE 1 | Information of the plant material used.

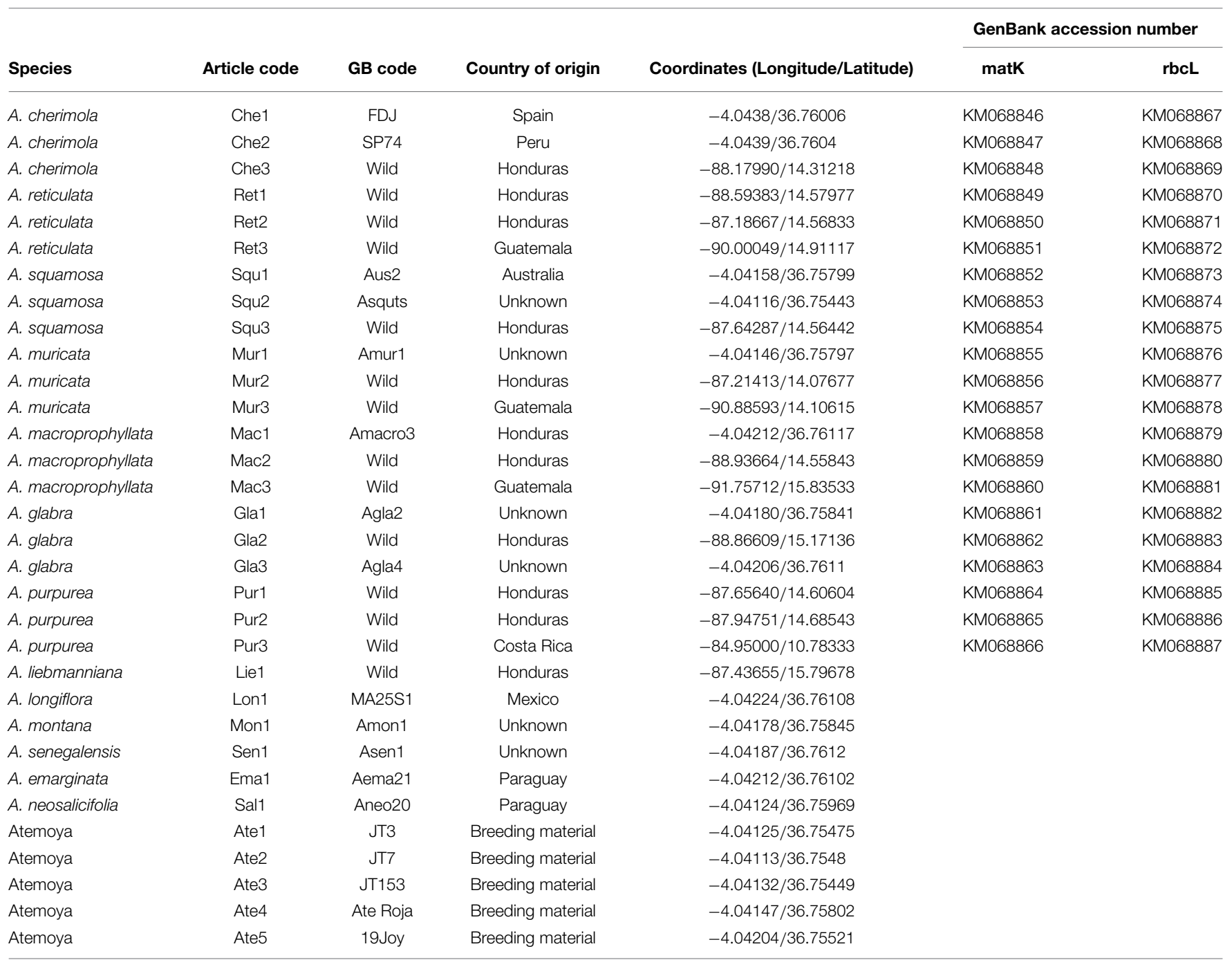

GB code refers to the code of the Germplasm Bank for the ex situ conserved material; "wild" stands for accessions not conserved ex situ.

carried out in an I-cycler (Bio-Rad Laboratories, Hercules, CA, USA) thermocycler using the following temperature profile: an initial step of $1 \mathrm{~min}$ at $94^{\circ} \mathrm{C}, 35$ cycles of $30 \mathrm{~s}$ at $94^{\circ} \mathrm{C}, 30 \mathrm{~s}$ at $60-69^{\circ} \mathrm{C}$ (Table 2), and $1 \mathrm{~min}$ at $72^{\circ} \mathrm{C}$, and a final step of $5 \mathrm{~min}$ at $72^{\circ} \mathrm{C}$. Amplicons were visualized in 1 or $3 \%$ agarose gels stained with Gel Red (1X).

Two multiplex PCR methods were developed for 6 of the 7 specific markers, depending on their annealing temperature. At $65^{\circ} \mathrm{C}$, primers AChF1, AChR1, AChReF1, AReR1, AMuF1, AMuR1 were placed in the same master PCR mix, only decreasing the concentration of AChF1 and AChR1 from 0.3 to $0.07 \mu \mathrm{M}$. At $69^{\circ} \mathrm{C}$, primers ASquF1, ASquR1, AMaF1, AMaR1, AGlaF1, AGlaR1 were also used together increasing every concentration from 0.3 to $0.4 \mu \mathrm{M}$.

Prior to sequencing, PCR solutions were purified with NucleoSpin ${ }^{\circledR}$ Extract II (Macherey-Nagel). Sequencing was done by the fluorescent dye terminator sequencing method (Macrogen).

\section{Barcode Sequence Quality and Species Discrimination}

Amplified matK and rbcL of the 21 different Annona DNA samples belonging to 7 species were sequenced in the forward direction. Chromatograms were analyzed by Chromas Lite version 2.1 (2012). The criteria used to establish an acceptable sequence were as follows (modified from Hanner, 2009): (i) ends were trimmed to minimize low quality base calls on each end; all bases were deleted until there were at least contiguous 10 pair bases with a PHRED score $>20$ (ii) bases with PHRED values less than 20 were recorded as N; (iii) sequences with more than $40 \%$ $\mathrm{N}$ base calls were deleted.

To assess the discriminatory power of both genes at the specific level, the 42 sequences obtained, 21 of matK and 21 of $\mathrm{rbcL}$, were aligned with MUSCLE implemented in the software MEGA5 version 5.05 (Tamura et al., 2011) using the default options. Pairwise sequence distances were calculated using the Kimura-2-parameter $(\mathrm{K} 2 \mathrm{P})$ that takes into account 
TABLE 2 | Details of the primers designed for identification of species of Annona including sequence, PCR melting and annealing temperatures, expected PCR product size and target species.

\begin{tabular}{|c|c|c|c|c|c|c|}
\hline Name & Sense & Sequence $5^{\prime}-3^{\prime}$ & Melting temp. $\left({ }^{\circ} \mathrm{C}\right)$ & Annealing temp. $\left({ }^{\circ} \mathrm{C}\right)$ & Expected size (bp) & Specificity \\
\hline AChF1 & $\mathrm{F}$ & GTATATGAATGTGAATCGGTATTC & 58.3 & 65 & 396 & Annona cherimola matk \\
\hline AChR1 & $\mathrm{R}$ & TTGACTCCTTACTGCGGAAT & 61.7 & & & \\
\hline AChReF1 & $\mathrm{F}$ & GCTTCGGAATGATTITCC & 60.1 & 65 & 364 & Annona reticulata matK \\
\hline AReR1 & $\mathrm{R}$ & CGCCTTAGCCAACGATT & 61.9 & & & \\
\hline ASqF1 & $\mathrm{F}$ & CCATTCCGTTTGTCAAAC & 62.2 & 69 & 315 & Annona squamosa matK \\
\hline ASqR1 & $\mathrm{R}$ & GGTAAGATITCCATTTCTTCATC & 59.8 & & & \\
\hline AMuF1 & $\mathrm{F}$ & CATTTACGATCAACATCCTTA & 58.6 & 65 & 332 & Annona muricata matk \\
\hline AMuR1 & $\mathrm{R}$ & GAAGAATITGGCGTACACTTA & 60.2 & & & \\
\hline AMaF1 & $\mathrm{F}$ & ATACAAGATGCTCCCTCTITG & 60.2 & 69 & 644 & Annona macroprophyllata matK \\
\hline AMaR1 & $\mathrm{R}$ & TTAGCCAATGATCCAATCATT & 61.2 & & & \\
\hline AGIF1 & $\mathrm{F}$ & CGATCAACATCCTITGGG & 62.1 & 69 & 476 & Annona glabra matK \\
\hline AGIR1 & $\mathrm{R}$ & GCCGGCTTACTAATAGGGTT & 61.3 & & & \\
\hline APuF1 & $\mathrm{F}$ & TTCTTGTTCCTATATAATATTCATA & 53.2 & 61 & 619 & Annona purpurea matk \\
\hline APuR1 & $\mathrm{R}$ & GAGAAAGATITCTGTATATGCGT & 58.5 & & & \\
\hline 1R_kim & $\mathrm{F}$ & ACCCAGTCCATCTGGAAATCTTGGTTC & & 52 & & Universal matK \\
\hline 3F_kim & $\mathrm{R}$ & CGTACAGTACTIITGTGTIACGAG & & & & \\
\hline rbcLa_F & $\mathrm{F}$ & ATGTCACCACAAACAGAGACTAAAGC & & $55-54$ & & Universal rbcL \\
\hline rbcLa_R & $\mathrm{R}$ & GTAAAATCAAGTCCACCRCG & & & & \\
\hline
\end{tabular}

transitions and transversions, with the same software (Aubriot et al., 2013). For each species, when the maximum intraspecific distance was lower than the minimum interspecific distance, discrimination was considered successful (CBOL Plant Working Group, 2009). In addition, a tree based identification approach was used. For that, all sequences of the genus Annona available in BOLD for each of the two genes analyzed were downloaded (access 08/2012) (Ratnasingham and Hebert, 2007); in total 20 sequences of matK belonging to 10 different species and 36 sequences of rbcL belonging to 24 different species were available (Supporting Information 1). Two Neighbor Joining (NJ) trees of K2P distances were constructed using the same program and running 1000 bootstrap replicates (Figure 1).

\section{Design of Species-specific Markers}

In order to design PCR-specific primers, newly sequenced alignments for matK and rbcL Annona DNA samples and the sequences downloaded from BOLD were used. Inter-species polymorphisms were studied manually using GENEDOC version 2.7. Intraspecific variations were not considered. The gene matK was selected for the development of 7 Annona specific markers. Pairs of specific primers were designed locating the $3^{\prime}$ end of each primer in specific shared polymorphic regions compared to the sequences that belonged to all the other species. Primers were designed to amplify targets of different length so PCR output could be determined by its position in a gel. To calculate melting temperatures and avoid as much as possible interaction among primers (also within different markers) we used the Multiple Primer Analyzer available at http:// www.thermoscientificbio.com/webtools/multipleprimer (access 02/2013). Primers designed are described in Table 2 and were validated in 6 additional Annona species through PCR amplification of DNA and visualization of the amplification fragments in agarose gels.

\section{Results}

\section{Barcode Sequences Quality and Species Discrimination}

All of the 42 sequences obtained fulfilled the established criteria to consider the sequencing reactions successful. Sequence sizes after the trimming process varied from 752 to $820 \mathrm{bp}$ in the case of matK and from 470 to 528 in the case of rbcL. The number of bases with a PHRED score below 20, so, therefore, substituted by $\mathrm{N}$, was between 0 and 7 , with the exception of sample Mur2 amplified with matK primers which had 61 bad quality bp (less of $40 \%$ of the sequence). All sequences were uploaded to the GenBank database and their accession numbers are indicated in Table 1.

Intraspecific sequence variability was only found in A. muricata. The maximum intraspecific distance was then compared to the minimum interspecific distance; in almost all cases the former was smaller than the latter (Table 3). Nucleotide sequence of the barcode gene matK could discriminate all 7 species, while rbcL could not distinguish between $A$. cherimola and $A$. squamosa samples.

The NJ trees obtained are shown in Figure 1. In the matK tree, new sequences from the 7 tested species grouped in different clusters. Besides, where applicable, sequences from the same species (newly obtained in this work and downloaded from BOLD) grouped together. In the case of rbcL, all the 21 new sequences clustered by species except A. cherimola and A. squamosa, that were grouped together. Furthermore, sequences from the same species downloaded from BOLD and the newly obtained sequences grouped together in the same cluster. Nevertheless, some species were mixed; in the cluster of $A$. cherimola and A. squamosa samples, three additional species (A. urbaniana, A. reticulata and $A$. pruinosa) downloaded from BOLD were present. A. holosericea 

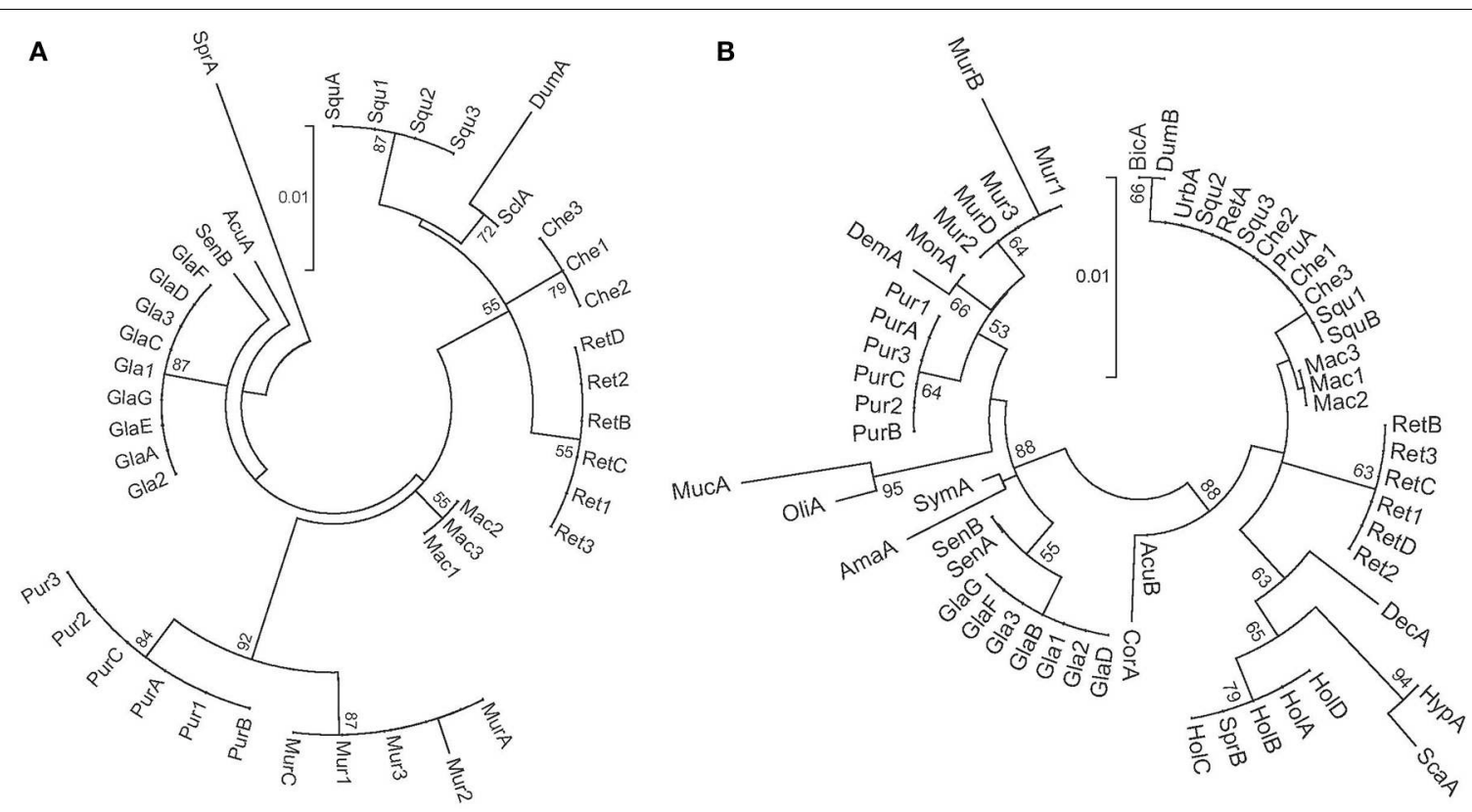

FIGURE 1 | Neighbor joining trees of pairwise K2P substitution rates using 41 matK sequences (A) and 57 rbcL sequences (B). Taxon codes are indicated in Table 1 and Supporting information 1. Bootstrap values of $50 \%$ and above are shown on the clusters. The scale bar represents the substitution rate per site.

TABLE 3 | Intra- and interspecific 2KP distances among the new sequences obtained.

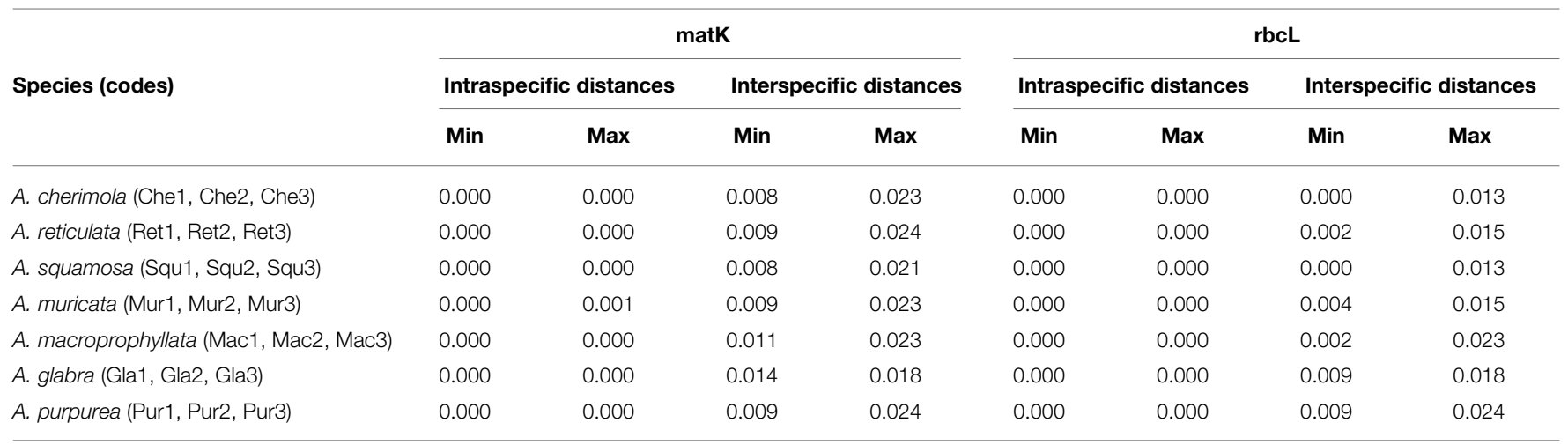

and A. spraguei BOLD samples appeared also in the same cluster.

\section{Specific Markers}

Seven markers were developed for 7 different Annona species. Details on the primer features and amplification conditions are summarized in Table 2. Primer specificity was verified using 13 samples of different Annona species (Supporting Information 2 ). For each species, just one band appeared when the specific markers developed were used.

In order to optimize routine species identification two multiplex PCR methods were developed. One for A. squamosa, A. macroprophyllata and A. glabra markers (all with $69^{\circ} \mathrm{C}$ annealing temperature), whose expected size amplicons are 315,644 , and $476 \mathrm{bp}$ respectively. The other, for $A$. cherimola, A. muricata and A. reticulata markers (all with $65^{\circ} \mathrm{C}$ annealing temperature), whose expected size amplicons are 396, 332, and 364 bp respectively. In addition, AChReF1 hybridizes with $A$. cherimola sequences so, when added to the same reaction than the AChR1 markers, a new band of $271 \mathrm{bp}$ appeared in the $A$. cherimola samples (Supporting Information 3).

These markers could also be used to study interspecific hybrids. Five atemoya samples, a hybrid of A. cherimola and A. squamosa, were analyzed with both loci. Four of the hybrid atemoyas where known to have $A$. cherimola as maternal parent and, as expected, those 4 samples only showed amplification bands when amplified with the $A$. cherimola specific primers (Supporting Information 4). The fifth sample, for which the direction of the cross was unknown, also showed this band when amplified with the $A$. cherimola specific marker, indicating $A$. squamosa as the pollen donor. 


\section{Discussion}

In this work we tested the two chloroplast loci, rbcL and matK, proposed for the barcode of plants by the $\mathrm{CBOL}$ (CBOL Plant Working Group, 2009), for differentiation of species of agronomic interest in the genus Annona. Sequences of other species of the genus present in the BOLD database were also included in the analysis. The results obtained by distance analysis methods with 21 genotypes belonging to 7 agronomical important Annona species showed almost no intraspecific variation, which could be due to the limited number of samples analyzed. One criticism of this kind of analyses is that often a very few individuals per species are studied or that incomplete geographic sampling is performed resulting in possible poor representation of the intraspecific variation or interspecific divergence, given rise to possible misleading results regarding barcoding gap and overlap between intraand interspecific variation (Meyer and Paulay, 2005). Although for some species the samples used here were obtained from different geographical areas, in other species the samples used just cover a small part of their distribution range; consequently, additional intraspecific variation could be present if samples from other regions were included in the analysis. Locus rbcL could distinguish 5 of the 7 species, showing overlap between intraand interspecific variation, while locus matK could distinguish all of them, since intraspecific distances were smaller than interspecific values, showing a barcode gap with the number of species studied. Both rbcL and matK have been recommended as core plant barcodes by CBOL (CBOL Plant Working Group, 2009) although, as shown in this work, rbcL usually displays a lower interspecific variation (Kress et al., 2005). Moreover, the universality of these two markers has been questioned in some particular taxa (Chase et al., 2007; Roy et al., 2010).

This initial analysis was broadened with comparison with additional sequences from other species of the genus Annona available in the BOLD database using NJ trees. Tree-based methods are also used for the identification of query samples when comparing its barcode sequences to a data set and the clustering position analyzed (van Velzen et al., 2012). Results, again, show a good performance of both genes, particularly of matK, since sequences from different individuals of the same species were grouped together in different clusters of the $\mathrm{NJ}$ tree. The mixed presence of some species in the NJ trees could be explained by this lower identification power of $\mathrm{rbcL}$ (when this number of different species is used) or by errors in species identification prior to uploading the sequences to the BOLD database. A multilocus analysis was not carried out since matK could discriminate all the species studied.

Newly obtained and BOLD matK sequences alignment was also used for the manual finding of specific polymorphic

\section{References}

APG, III. (2009). An update of the Angiosperm Phylogeny Group classification for the orders and families of flowering plants: APG III. Bot. J. Linn. Soc. 161, 105-121. doi: 10.1111/j.1095-8339.2009.00996.x nucleotides. These were used for the development of 7 specific markers, relying on the idea of diagnostic positions. In fact, character-based diagnosis methods are the other big group used in traditional barcode techniques. They count just on relevant diagnostic positions of the sequence that would support a particular classification (DeSalle et al., 2005).

In the case of Annona species, the development of fast, reliable and economic tools, such as specific markers, to identify these promising subtropical resources in a very initial state of domestication is of great importance in order to optimize genetic resource management. In addition, since these markers are chloroplast based genes, their presence or absence in interspecific hybrids could serve to discern hybridization processes in these species; some of them are known to hybridize easily (such as A. cherimola and A. squamosa) although some authors (Zill and Mahdeem, 1998; George et al., 2002) have reported other hybrids in the genus (such as A. cherimola $\mathrm{x} A$. reticulata or $A$. squamosa $\mathrm{x} A$. diversifolia) at least as a result of artificial pollination. The markers described in this work are appropriate for the discrimination of the most important species of the genus from an agronomic point of view although, since the genus Annona includes about 160 species (Chatrou et al., 2012), additional work will be needed to develop appropriate identification tools for all the species of the genus.

\section{Author Contributions}

$\mathrm{JH}$ and NL conceived, designed the study and wrote the paper. NL performed the molecular experiments and analyzed the data.

\section{Acknowledgments}

This work was supported by Ministerio de Economía y Competitividad - European Regional Development Fund, European Union (AGL2010-15140, AGL2013-43732-R), the BBVA Foundation (BIOCON 08 - 184/09) and INIA (RF201200010 and RFP2012-00016). NL was supported by an FPI fellowship from Ministerio de Economía y Competitividad. We thank Javier Ajú for providing some sequences for primer design, Federico Albertazzi, Marlon Durón, Gustavo Fontecha and Margarita Palmieri for collecting some of the leaf samples used in this work and Yolanda Verdún for technical assistance.

\section{Supplementary Material}

The Supplementary Material for this article can be found online at: http://journal.frontiersin.org/article/10.3389/fpls.2015. 00589

Aubriot, X., Lowry, I. I. P. P., Cruaud, C., Couloux, A., and Haevermans, T. (2013). DNA barcoding in a biodiversity hot spot: potential value for the identification of Malagasy Euphorbia L. listed in CITES Appendices I and II. Mol. Ecol. Resour. 13, 57-65. doi: 10.1111/1755-0998. 12028 
Bhargava, M., and Sharma, A. (2013). DNA barcoding in plants: evolution and applications of in silico approaches and resources. Mol. Phylogenet. Evol. 67, 631-641. doi: 10.1016/j.ympev.2013.03.002

CBOL Plant Working Group. (2009). A DNA barcode for land plants. Proc. Natl. Acad. Sci. U.S.A. 106, 12794-12797. doi: 10.1073/pnas.0905 845106

Chaowasku, T., Thomas, D. C., van der Ham, R. W., Smets, E. F., Mols, J. B., and Chatrou, L. W. (2014). A plastid DNA phylogeny of tribe Miliuseae: insights into relationships and character evolution in one of the most recalcitrant major clades of Annonaceae. Am. J. Bot. 101, 691-709. doi: 10.3732/ajb.1300403

Chase, M. W., Cowan, R. S., Hollingsworth, P. M., van den Berg, C., Madrinan, S., Petersen, G., et al. (2007). A proposal for a standardised protocol to barcode all land plants. Taxon 56, 295-299.

Chatrou, L. W., Escribano, M. P., Viruel, M. A., Maas, J. W., Richardson, J. E., and Hormaza, J. I. (2009). Flanking regions of monomorphic microsatellite loci provide a new source of data for plant species-level phylogenetics. Mol. Phylogenet. Evol. 53, 726-733. doi: 10.1016/j.ympev.2009.07.024

Chatrou, L. W., Pirie, M. D., Erkens, R. H. J., Couvreur, T. L. P., Neubig, K. M., Abbott, J. R., et al. (2012). A new subfamilial and tribal classification of the pantropical flowering plant family Annonaceae informed by molecular phylogenetics. Bot J Linnn Soc, 169, 5-40. doi: 10.1111/j.10958339.2012.01235.x

Chen, S. L., Yao, H., Han, J. P., Liu, C., Song, J. Y., Shi, L. C., et al. (2010). Validation of the ITS2 region as a novel DNA barcode for identifying medicinal plant species. PLoS ONE 5:e8613. doi: 10.1371/journal.pone.0008613

China Plant BOL Group, Li, D. Z., Gao, L. M., Li, H. T., Wang, H., Ge, X. J. et al. (2011). Comparative analysis of a large dataset indicates that internal transcribed spacer (ITS) should be incorporated into the core barcode for seed plants. Proc. Natl. Acad. Sci. U.S.A. 108, 19641-19646. doi: 10.1073/pnas.1104551108

DeSalle, R., Egan, M. G., and Siddall, M. (2005). The unholy trinity: taxonomy, species delimitation and DNA barcoding. Phil. Trans. R Soc. B 360, 1905-1916. doi: 10.1098/rstb.2005.1722

Ellstrand, N. C., and Lee, J. M. (1987). Cultivar identification of cherimoya (Annona cherimola Mill.) using isozyme markers. Sci. Hortic. 32, 25-31. doi: 10.1016/0304-4238(87)90013-6

Escribano, P., Viruel, M. A., and Hormaza, J. I. (2004). Characterization and cross-species amplification of microsatellite markers in cherimoya (Annona cherimola Mill., Annonaceae). Mol. Ecol. Notes 4, 746-748. doi: 10.1111/j.14718286.2004.00809.x

Escribano, P., Viruel, M. A., and Hormaza, J. I. (2007). Molecular analysis of genetic diversity and geographic origin within an ex situ germplasm collection of cherimoya by using SSRs. J. Am. Soc. Hortic. Sci. 132, 357-367.

Escribano, P., Viruel, M. A., and Hormaza, J. I. (2008a). Development of 52 new polymorphic SSR markers from cherimoya (Annona cherimola Mill.): transferability to related taxa and selection of a reduced set for DNA fingerprinting and diversity studies. Mol. Ecol. Resour. 8, 317-321. doi: 10.1111/j.1471-8286.2007.01941.x

Escribano, P., Viruel, M. A., and Hormaza, J. I. (2008b). Comparison of different methods to construct a core germplasm collection in woody perennial species with SSR markers. A case study in cherimoya (Annona cherimola Mill.), an underutilized subtropical fruit tree species. Ann. Appl. Biol. 153, 25-32. doi: 10.1111/j.1744-7348.2008.00232.x

George, A. P., Broadley, R. H., Nissen, R. J., and Hamill, S. D. (2002). Breeding new varieties of atemoya (Annona spp. hybrids). Acta Hort. 575, 323-328.

Hanner, R. (2009). Data standars for barcode records in INSDC (BRis). Available online at: http://barcoding.si.edu/pdf/dwg_data_standards-final.pdf. Accessed March 2015

Hebert, P. D. N., Cywinska, A., Ball, S. L., and DeWaard, J. R. (2003). Biological identifications through DNA barcodes. Proc. R. Soc. B. Biol. Sci. 270, 313-321. doi: $10.1098 / \mathrm{rspb} .2002 .2218$

Hollingsworth, P. M. (2011). Refining the DNA barcode for land plants. Proc. Natl. Acad. Sci. U.S.A. 108, 19451-19452. doi: 10.1073/pnas.111 6812108

Kress, W. J., Wurdack, K. J., Zimmer, E. A., Weigt, L. A., and Janzen, D. H. (2005). Use of DNA barcodes to identify flowering plants. Proc. Natl. Acad. Sci. U.S.A. 102, 8369-8374. doi: 10.1073/pnas.0503123102
Li, X., Yang, Y., Henry, R. J., Rossetto, M., Wang, Y., and Chen, S. (2015). Plant DNA barcoding: from gene to genome. Biol. Rev. 90, 157-166. doi: 10.1111/brv.12104

Meyer, C. P., and Paulay, G. (2005). DNA barcoding: error rates based on comprehensive sampling. PLoS Biol. 3:e422. doi: 10.1371/journal.pbio.00 30422

Nicolas, V., Schaeffer, B., Missoup, A. D., Kennis, J., Colyn, M., Denys, C., et al. (2012). Assessment of three mitochondrial genes (16S, Cytb, CO1) for identifying species in the praomyini tribe (Rodentia: Muridae). PLoS ONE 7:e36586. doi: 10.1371/journal.pone.0036586

Pang, X. H., Liu, C., Shi, L. C., Liu, R., Liang, D., Li, H., et al. (2012). Utility of the trnH-psbA intergenic spacer region and its combinations as plant DNA barcodes: a meta-analysis. PLoS ONE 7:e48833. doi: 10.1371/journal.pone. 0048833

Pascual, L., Perfectti, F., Gutierrez, M., and Vargas, A. M. (1993). Characterizing isozymes of Spanish cherimoya cultivars. Hort. Sci. 28, 845-846.

Pereira, M. F., Bandeira, L. F., Blanco, A. J., Ciampi, A. Y., and Coelho, A. S. (2008). Development of microsatellite markers in Annona crassiflora Mart. a Brazilian Cerrado fruit tree species. Mol. Ecol. Resour. 8, 1329-1331. doi: 10.1111/j.1755-0998.2008.02275.x

Perfectti, F., and Pascual, L. (1998). Characterization of cherimoya germplasm by isozyme markers. Fruit Varieties J. 52, 53-62.

Perfectti, F., and Pascual, L. (2004). Geographic variation for isozymes in cherimoya (Annona cherimola Mill). Genet. Resour. Crop Ev. 51, 837-843. doi: 10.1007/s10722-005-0925-5

Perfectti, F., and Pascual, L. (2005). Genetic diversity in a wordwide collection of cherimoya cultivars. Genet. Resour. Crop Ev. 52, 959-966. doi: 10.1007/s10722003-6093-6

Popenoe, H. (1989). Lost Crops of the Incas: Little-known Pof the Andes with Promise for Worldwide Cultivation. Washington, DC: National Academy Press.

Rahman, M. S. M., Shimada, T., Yamamoto, T., Yonemoto, J. Y., and Yoshida, M. (1998). Genetical diversity of cherimoya cultivars revealed by amplified fragment length polymorphism (AFLP) analysis. Breeding Sci. 48, 5-10.

Ratnasingham, S., and Hebert, P. D. N. (2007). BOLD: the barcode of life data system (www.barcodinglife.org). Mol. Ecol. Notes 7, 355-364. doi: 10.1111/j.1471-8286.2007.01678.x

Richardson, J. E., Chatrou, L. W., Mols, J. B., Erkens, R. H. J., and Pirie, M. D. (2004). Historical biogeography of two cosmopolitan families of flowering plants: annonaceae and Rhamnaceae. Phil. Trans. R. Soc. B Biol. Sci. 359, 1495-1508. doi: 10.1098/rstb.2004.1537

Ronning, C. M., Schell, J. R., and Gazit, S. (1995). Using randomly amplified polymorphic DNA (RAPD) markers to identify Annona cultivars. J. Amer. Soc. Hort. Sci. 120, 26-729.

Roy, S., Tyagi, A., Shukla, V., Kumar, A., Singh, U. M., Chaudhary, L. B., et al. (2010). Universal plant DNA barcode loci may not work in complex groups: a case study with Indian Berberis species. PLoS ONE 5:e13674. doi: 10.1371/journal.pone.0013674

Tamura, K., Peterson, D., Peterson, N., Stecher, G., Nei, M., and Kumar, S. (2011). MEGA5: molecular evolutionary genetics analysis using maximum likelihood, evolutionary distance, and maximum parsimony methods. Mol. Biol. Evol. 28, 2731-2739. doi: 10.1093/molbev/msr121

Thomas, D. C., Surveswaran, S., Xue, B., Sankowsky, G., Mols, J. B., Keßler, P. J. A., et al. (2012). Molecular phylogenetics and historical biogeography of the Meiogyne-Fitzalania clade (Annonaceae): Generic paraphyly and late Miocene-Pliocene diversification in Australasia and the Pacific. Taxon 61, 559-575.

Vanhove, W., and van Damme, P. (2013). Value chains of cherimoya (Annona cherimola Mill.) in a centre of diversity and its on-farm conservation implications. Trop. Cons. Sci. 6, 158-180.

van Velzen, R., Weitschek, E., Felici, G., and Bakker, F. T. (2012). DNA barcoding of recently diverged species: relative performance of matching methods. PLoS ONE 7:e30490. doi: 10.1371/journal.pone.0030490

van Zonneveld, M., Scheldeman, X., Escribano, P., Viruel, M. A., Van Damme, P., Garcia, W., et al. (2012). Mapping genetic diversity of cherimoya (Annona cherimola Mill.): application of spatial analysis for conservation and use of plant genetic resources. PLOS ONE 7:e29845. doi: 10.1371/journal.pone. 0029845 
Viruel, M. A., and Hormaza, J. I. (2004). Development, characterization and variability analysis of microsatellites in lychee (Litchi chinensis Sonn., Sapindaceae). Theor. Appl. Genet. 108, 896-902. doi: 10.1007/s00122-003$1497-4$

Zhang, C. Y., Wang, F. Y., Yan, H. F., Hao, G., Hu, C. M., and Ge, X. J. (2012). Testing DNA barcoding in closely related groups of Lysimachia L. (Myrsinaceae). Mol. Ecol. Resour. 12, 98-108. doi: 10.1111/j.17550998.2011.03076.x

Zill, G. E., and Mahdeem, H. (1998). General observations on hybridizing Annona species. Proc. Fla. State Hort. Soc. 111, 314-315.
Conflict of Interest Statement: The authors declare that the research was conducted in the absence of any commercial or financial relationships that could be construed as a potential conflict of interest.

Copyright $(02015$ Larranaga and Hormaza. This is an open-access article distributed under the terms of the Creative Commons Attribution License (CC BY). The use, distribution or reproduction in other forums is permitted, provided the original author(s) or licensor are credited and that the original publication in this journal is cited, in accordance with accepted academic practice. No use, distribution or reproduction is permitted which does not comply with these terms. 


\section{ANEXO 2}

Larranaga N, Hormaza Jl (2016) Advances in genetic diversity analysis in fruit tree crops. Lüttge U, Cánovas FM, Matyssek R. Progress in Botany 77. Springer International Publishing, Switzerland, 245-264. 


\title{
Advances in Genetic Diversity Analysis in Fruit Tree Crops
}

\author{
Nerea Larrañaga and José Ignacio Hormaza
}

\section{Contents}

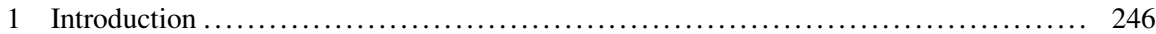

2 Molecular Markers and Genetic Diversity in Fruit Tree Crops .................... 248

2.1 Main Types of Molecular Markers Used in Genetic Diversity Analyses in Fruit Trees ....................................................... 248

2.2 Evolution of the Use of Different DNA-Based Markers for Diversity Analyses in Fruit and Nut Crops ............................................ 250

2.3 Interpretation of the Results Obtained: Parameters and Software Tools ........ 251

3 Perspectives of Next-Generation DNA Sequencing (NGS) for Studies of Genetic

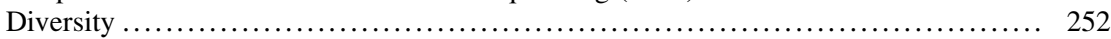

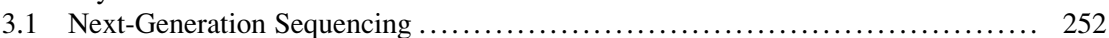

3.2 Applications of NGS in Fruit and Nut Tree Crops ........................ 253

4 Use of Geographic Tools and Landscape Genetics in the Study of Genetic Diversity ... 254

4.1 Geographic Information Systems ................................... 254

4.2 Landscape Genetics ............................................ 255

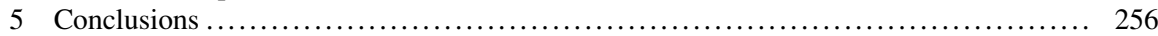

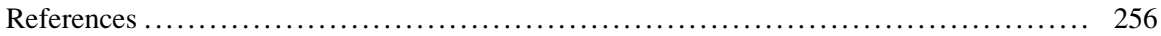

\begin{abstract}
Critical advances in the application of molecular tools to analyze genetic diversity in annual and perennial crops have taken place in the last two decades. Although in most cases the new technologies are first developed in annual crops, some particularities of most fruit crops, such as their perennial nature, long generation time, large individual size, or vegetative propagation, make the advantages of using these new approaches even more relevant in these species. In this work, the information available on the different strategies used to analyze genetic diversity in temperate and tropical fruit tree species using molecular approaches is reviewed. Special attention is given to the potential of next-generation sequencing and the combination of genomic tools with geographic information systems.
\end{abstract}

\footnotetext{
N. Larrañaga • J.I. Hormaza $(\bowtie)$

Instituto de Hortofruticultura Subtropical y Mediterránea La Mayora (IHSM-UMA-CSIC),

Estación Experimental La Mayora, Algarrobo-Costa, Málaga 29750, Spain

e-mail: ihormaza@eelm.csic.es
} 


\section{Introduction}

Conservation and sustainable management of crop genetic resource diversity is the key for guaranteeing food security for future generations since this will determine the ability of populations and crops as a whole to adapt to environmental changes. This is becoming increasingly important in the current scenario of global climatic change where conserving genomic pools that will allow the development of resilient cultivars to a wide range of biotic and abiotic stresses is an increasing necessity. In this sense, it is important to keep in mind that conservation of plant genetic resources worldwide has been concentrated on a small group of species. Thus, from about 7,000 plant species that have been indeed used by humans (Hammer 2003), currently about 30 species contribute to more than $90 \%$ of human nutrition globally, and just three cereals (wheat, rice, and maize) account for about two-thirds of human dietary needs (Cassman 1999). Moreover, in order to be effective in the long term, this conservation effort should also include crop wild relatives that can be source of interesting genes (Ford-Lloyd et al. 2011).

Of the 30 most important crops in terms of production worldwide, only five can be considered as fruit crops (bananas, oranges, grapes, apples, and mangoes) (Faostat 2014) although perennial crops account for about one-eighth of the world cultivated area (McClure et al. 2014). However, there are hundreds of neglected and underutilized fruit crops that are important in specific local markets and which cultivation can be extended in the future. As an example, it is considered that less than $5 \%$ of the edible tropical fruit trees are cultivated commercially (Wijeratnam 2000) and just five species [banana (several species of the genus Musa), mango (Mangifera indica), pineapple (Ananas comosus), avocado (Persea americana), and papaya (Carica papaya)] comprise more than $90 \%$ of the export of tropical fruits of those countries. In many cases, especially for underutilized fruit tree crops, most of the extant diversity is present in developing countries, and, consequently, the long-term conservation of their genetic resources is at risk since the capacity for studying and managing germplasm collections, including qualified personnel, is generally directly related to the degree of economic development of the country where the collection is situated.

Common characteristics of most fruit crops compared to domesticated annual crops are their perennial nature, long generation cycles, and long juvenile periods that often limit breeding programs and hinder genetic conservation efforts. Additionally, most fruit crops are highly heterozygous and usually propagated vegetatively favoring the cultivation of a few clones of selected cultivars. As a result, often the genetic diversity found in most of the commercially cultivated fruit tree crops is low (McClure et al. 2014). However, while most annual crops have been domesticated over a long period of time, only very few woody perennial tree species can be considered as truly domesticated. Consequently, most are separated by few generations from their wild relatives which can become interesting sources of additional genes. 
The significant loss in biodiversity during the last decades has resulted in an increasing interest worldwide in conservation of plant genetic resources as shown through different national/international agreements and treaties such as the Convention on Biological Diversity in 1992 (http://www.cbd.int/history/) or the International Treaty on Plant Genetic Resources for Food and Agriculture in 2001 (http://www.planttreaty.org/), among many others. Genetic diversity, which can be defined as the amount of genetic variability among individuals of a variety, population, or species (Brown 1983), can be preserved through the conservation of germplasm. This can be performed both in situ and ex situ, two complementary approaches that, especially for the in situ component, should be integrated into a sustainable development strategy in the regions where biodiversity is present. In situ conservation of agricultural biodiversity can be carried out through the preservation of protected wild areas and/or the preservation of traditional cultivated fields ("on farm" conservation). The latter also includes the accompanying traditional agricultural methods and knowledge of local farmers and preserves interaction that takes place in ecosystems and, thus, the coevolution between all the elements that generate new diversity. Ex situ conservation programs preserve isolated genotypes (e.g., vegetative field collections, seeds, or in vitro culture banks). Most current ex situ germplasm collections show important limitations in the number of accessions and in the genetic variability and quality of the samples conserved. This situation is aggravated for certain species with recalcitrant seeds, such as many fruit trees, where conservation is not performed through seed collections but in living field collections which are very expensive to maintain. At least two complementary approaches can be envisaged to reduce maintenance costs in perennial fruit tree species. One approach involves the development of core collections that represent most of the diversity conserved in a small number of genotypes (van Hintum et al. 2000; Escribano et al. 2008). Another approach is based on a shift toward on-farm management of agrobiodiversity as a form of in situ conservation for the use of plant genetic resources in a dynamic production system (Hammer 2003). In any case, the establishment of appropriate measures for the conservation of the extant diversity in any crop species requires the availability of appropriate information on the distribution and structure of its current diversity.

Characterization of conserved and existent but as yet still unexplored genetic diversity is necessary to preserve the genetic resources of crop species for a sustainable use by future generations. The optimization of the management of genetic resources requires not only a precise identification and evaluation of the accessions already conserved but also to establish where hot spots of diversity exist in order to provide guidelines for future conservation of as yet non-collected variability. Recent advances in molecular genetics and the application of geographic information systems could represent new opportunities both for the management of biodiversity in situ and for the conservation of biodiversity in ex situ germplasm collections.

In this chapter we will focus on the most popular approaches used in recent years to study genetic diversity of fruit trees, with special attention to molecular techniques and the application of spatial analysis tools. 


\section{Molecular Markers and Genetic Diversity in Fruit Tree Crops}

Traditionally, genotype identification and diversity studies in cultivated plant species including fruit trees have been carried out through morphological markers and phenotypic trait characterization. However, this is a slow and expensive process that limits the number of genotypes that can be studied as well as the accuracy of the observations. Some of those observations, like those related to phenological characters, need to be analyzed late in development, and some can affect other morphological characters or agronomical traits due to pleiotropic gene action (Le Corre and Kremer 2003). Although these observations can still be very useful tools to match phenotype with genotype and a good phenotyping is ultimately needed to link molecular markers with traits of interest, genotype characterization and genetic diversity studies in plants require research strategies that complement phenotypic characterization and estimation of diversity such as molecular techniques (Wünsch and Hormaza 2002). During the last two decades, fast and important advances in the methods used to study nucleic acids in both animals and plants have taken place resulting in the continuous development of different types of genetic markers. These allow reliable estimations of allelic richness reflected in the number and distribution of alleles per locus, which is the main parameter to measure genetic diversity. This information can be used to analyze the population structure of in situ and ex situ germplasm collections and wild stands of cultivated species and crop wild relatives in order to develop appropriate strategies to optimize the conservation of genetic diversity.

\subsection{Main Types of Molecular Markers Used in Genetic Diversity Analyses in Fruit Trees}

Molecular markers can be biochemical or based on DNA sequences. Biochemical markers involve the separation of proteins (allozymes and isozymes) into specific banding patterns by electrophoresis. They are codominant, and their main disadvantage is that the number of available enzymes is limited and, thus, their power to analyze diversity is reduced (Mondini et al. 2009). They have been used since the 1970s to analyze genetic diversity in plants (Brown 1978), but they can still provide valuable information for diversity studies in fruit trees shown in some recent works in apple (Wagner et al. 2014), hazelnut (Leinemann et al. 2013), or Arbutus unedo (Takrouni et al. 2012).

DNA-based markers, commonly known as molecular markers, have been continuously developed since the 1980s and can be associated or not to a functional trait; they can, in general terms, be classified into dominant (such as RAPDs or AFLPs) or codominant (such as RFLPs, microsatellites, or SNPs) markers depending on whether heterozygous and homozygous genotypes can be 
distinguished. RFLPs, widely used since Alec Jeffreys discovered the polymorphism in the fragment size after treating the DNA with restriction enzymes (Jeffreys 1979), have been applied in numerous works to assess fruit tree diversity; although due to the availability of new molecular approaches their application for genetic diversity studies is in disuse, some recent examples can still be found in fruit tree crops (Garcia-Ruiz et al. 2013).

Since the development of PCR in the mid-1980s by the Noble Prize winner in Chemistry 1993, Kary Mullis (Mullis et al. 1986), different types of PCR-based molecular markers have been developed. Among those routinely used in ecological, evolutionary, taxonomic, phylogenetic, and genetic diversity studies are randomly amplified polymorphic DNAs (RAPDs), in which fragments of genomic DNA are amplified using a decamer primer of random sequence and where polymorphism depends upon the presence or absence of an amplification product. They started to be used in different organisms in the late 1980s (Williams et al. 1990) and have been used extensively in a wide range of fruit tree crops; recent examples include pomegranate (Mansour et al. 2015), olive (Brake et al. 2014), apricot (Yilmaz et al. 2012), or mango (Samal et al. 2012). Amplified fragment length polymorphisms (AFLPs) (Vos et al. 1995) combine RFLP and PCR techniques. They have also been used in studies of diversity of different plant species (Mba and Tohme 2005); recent examples in fruit trees include Prunus mira (Li et al. 2014a), date palm (Sabir et al. 2014), or kiwifruit (Li et al. 2014b). Simple sequence repeats (SSRs) or microsatellites (Litt and Luly 1989), based in the presence of repetitive DNA sequences in eukaryote genomes flanked by specific conserved regions that allow their amplification by PCR, became the markers of choice for fingerprinting and diversity analyses in recent years (Ellegren 2004; Kalia et al. 2011; Arias et al. 2012). Some recent examples of their use for diversity studies in fruit trees include grapevine (Basheer-Salimia et al. 2014), apricot (Raji et al. 2014; Martin et al. 2011), chestnut (Beghe et al. 2013), litchi (Madhou et al. 2013), or pear (Sehic et al. 2012). Additional PCR-based markers used to some extent are inter-simple sequence repeats (ISSRs), applied, for example, in fig (Amel et al. 2004, 2005; Ikegami et al. 2009) or clementine (Breto et al. 2001); cleaved amplified polymorphisms (CAPs) used, for example, in Citrus spp. (Amar et al. 2011); sequenced characterized amplified regions (SCARs) used, for example, in persimmon (Cho et al. 2013); or sequence-tagged sites and expressed sequence tags (STS and ESTs, respectively) used, for example, in Musa acuminata (Passos et al. 2012) or Actinidia spp. (Crowhurst et al. 2008). Other less used molecular markers include start codon targeted polymorphisms (SCoT) that uses single primers designed to anneal to the flanking regions of the ATG initiation codon on both DNA strands and has been used in Mangifera indica (Gajera et al. 2014; Luo et al. 2011) and SRAP and TRAP, which stand for sequence-related amplified polymorphism and targeted region amplified polymorphism, respectively, that have been used in several fruit tree species. In the case of SRAP, recent works in fruit trees include apricot (Li et al. 2014c), persimmon (Jing et al. 2013a), or almond (Jing et al. 2013b), and, in the case of TRAP, apple (Guo et al. 2009). Another group of markers is based on mobile elements; examples include inter-retrotransposon amplified 
polymorphism (IRAP) that has been used in Musa spp. (Nair et al. 2005) or Diospyros spp. (Du et al. 2009a, b), the retrotransposon-microsatellite amplified polymorphism (REMAP) that has been used in Diospyros spp. (Du et al. 2009a, b) or Prunus mume (Shen et al. 2011), retrotransposon-based insertion polymorphism (RBIP) in Pyrus pyrifolia (Kim et al. 2012), or the retrotransposon-based sequencespecific amplification polymorphism (SSAP) in Anacardium occidentale (Syed et al. 2005) or Diospyros spp. (Du et al. 2009a, b).

More recently, simple nucleotide polymorphisms (SNPs), which are variations of single nucleotides which do not change the overall length of the DNA sequence in the region and occur throughout the genome, are being increasingly used (FAO 1997; de Vicente et al. 2004) especially due to the increasingly more economic availability of next-generation sequencing methods (see next section).

Whereas the previous markers usually target nuclear DNA, chloroplast and mitochondrial DNA can also be used to some extent to estimate genetic diversity although they are more useful at the interspecific level due to the usually low level of intraspecific polymorphism. Chloroplast and mitochondrial DNA analysis are of common use in barcode and phylogenetic studies in plant and animals, respectively, and they can be useful tools to assign unknown sample to the correct species and avoid errors that can affect the results obtained in genetic diversity analyses (Larrañaga and Hormaza 2015).

\title{
2.2 Evolution of the Use of Different DNA-Based Markers for Diversity Analyses in Fruit and Nut Crops
}

\begin{abstract}
Although genetic diversity studies in annual crops clearly outnumber those in woody perennial crops, a great number of studies have been published on the application of molecular markers to study genetic diversity in temperate and tropical fruit tree crops. Thus, a basic search in the ISI web of knowledge for the seven most common types of markers (AFLP, ISSR, RAPD, SSR, RFLP, SNP +EST, and NGS), with the keyword "diversity", and 32 important genera of temperate and tropical tree fruit crops (Actinidia, Anacardium, Annona, Averrhoa, Carica, Carya, Castanea, Citrus, Cocos, Cydonia, Dimocarpus, Diospyros, Eryobotria, Ficus, Juglans, Litchi, Malus, Mangifera, Musa, Olea, Passiflora, Persea, Phoenix, Pistacia, Prunus, Psidium and Vitis) provides the following results as of February 2015: 1,229 studies for SSRs, 776 for RAPDs, 418 for AFLPs, 236 for RFLPs, 193 for ISSRs, 159 for SNP+EST, and 25 for NGS. These results are represented in Fig. 1 by year to show the variation in the number of studies with time. It is interesting to note that, although new molecular marker technologies are being developed continuously, some of the ones used 20 years ago (such as RAPDs) are still being used.

Molecular markers have been mainly used in fruit tree species commercially important at a global level; those include, for example, Prunus spp., Malus spp.,
\end{abstract}




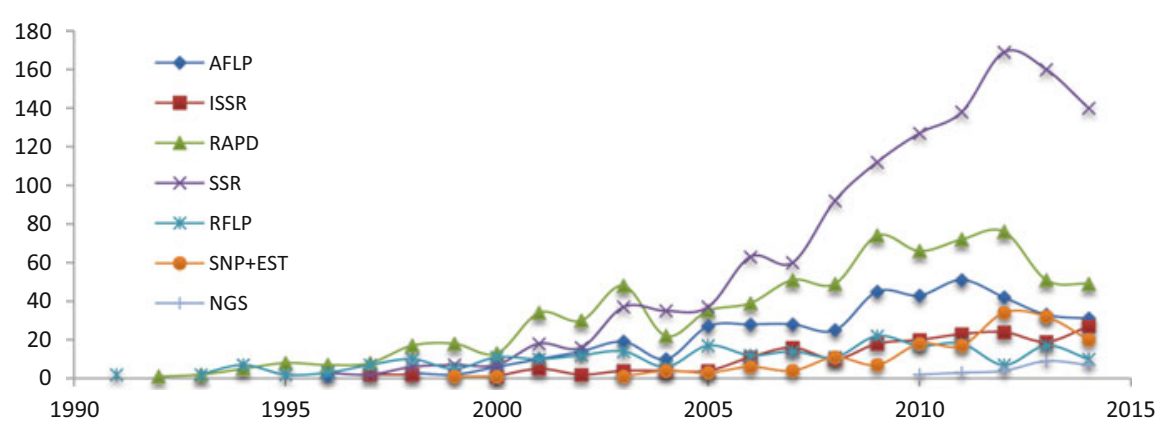

Fig. 1 Number of studies per year and per type of molecular marker shown by the Web of knowledge

Citrus spp., Vitis vinifera, or Theobroma cacao. However, some works have also been performed in crops that can be considered as "neglected" or "underutilized" species such as the Ethiopian banana, Ensete ventricosum (Birmeta et al. 2004); highland papayas, Vasconcellea sp. (van Droogenbroeck et al. 2004, 2006); cherimoya, Annona cherimola (Escribano et al. 2007; van Zonneveld et al. 2012); guava, Psidium guajava (Coser et al. 2012); or baobab, Adansonia digitata (Munthali et al. 2013). An additional set of studies have also focused on fruit tree crop wild relatives (CWR) such as Rubus idaeus (Graham et al. 2003); Pistacia khinjuk and Pistacia atlantica (Shanjani et al. 2009); Olea europaea subsp. cuspidata (Koehmstedt et al. 2011); Malus sylvestris, M. orientalis, and M. sieversii (Cornille et al. 2013); or Citrus macroptera (Malik et al. 2013). The characterization and conservation of genetic diversity in CWRs is becoming of increasing interest especially in the current context of climate change since they can be useful to incorporate into crops a range of useful genes to increase resiliency and productivity (Warschefsky et al. 2014). Clearly, additional resources and international cooperation networks should be devoted to address diversity studies and germplasm conservation programs in those two last groups, neglected and CWR species (FordLloyd et al. 2011; Mba et al. 2012).

\subsection{Interpretation of the Results Obtained: Parameters and Software Tools}

The variances or polymorphisms shown by the different molecular markers can be analyzed with a range of different diversity parameters based (i) on the number of variants (number of percentage of polymorphic loci or allelic richness, i.e., mean number of alleles per locus) or (ii) on the frequencies of the alleles obtained (effective population size, expected and observed heterozygosities, or fixation index). Genetic diversity between different (sub)populations/collections is based on significant differences in allele frequencies among the different groups that can 
be estimated with F-statistics, Rst, Gst, or AMOVA, among others. In addition, graphic representation of genetic distances and cluster analyses are usually performed to visualize relationships among the different genotypes studied. Although this is starting to change due to the increasing availability of new generation sequencing technologies, usually just a small portion of the genome is explored in most genetic diversity studies, and, thus, the selection of a correct amount of individuals and loci to be analyzed is of great importance to make reliable extrapolation from the estimators to the natural populations or germplasm collections (de Vicente et al. 2004; Mondini et al. 2009; Porth and El-Kassaby 2014). Different software packages have been developed in the last two decades to obtain these genetic diversity measures; among them, some of the most commonly used are Genepop (Raymond and Rousset 1995), Popgene (Yeh et al. 1997), Arlequin (Excoffier et al. 2005), PowerMarker (Liu and Muse 2005), Ntsys-pc (Rohlf 2008), GenAlEx (Peakall and Smouse 2012), and Mega (Tamura et al. 2013). In addition, several software packages based in R (www.r-project. org) also allow the analysis of marker data for genetic diversity studies; among them, the most commonly used are Hierfstat (Goudet 2005), Adegenet (Jombart 2008), and DiveRsity (Keenan et al. 2013). The genetic structure of populations can be assessed using a method developed by Pritchard et al. (2000) implemented in the software program Structure. The program assigns probable individual haplotypes to multiple clusters relying on the allele frequencies at each locus identifying clusters of individuals on the basis of their genotypes at multiple loci using a Bayesian approach.

\section{Perspectives of Next-Generation DNA Sequencing (NGS) for Studies of Genetic Diversity}

\subsection{Next-Generation Sequencing}

During the 1970s, two different sequencing methods were developed by Frederick Sanger and Allan Maxam and Walter Gilbert, respectively (Sanger et al. 1977; Maxam and Gilbert 1977). The first became widely used for more than 25 years. In 2001, when the first draft of the human genome project was released, the scientific community started to look for cheaper and other approaches not based on cloning fragments (Mardis 2008). It was not until 2004 that next-generation DNA sequencing methods, sometimes classified in second and third generation automatic sequencers, depending whether prior amplification of the DNA template is needed (Glenn 2011), appeared in the market. These technologies provide several advantages and have revolutionized many areas in biology since they allow genome-wide characterization and profiling of mRNAs, small RNAs, transcription factor regions, structure of chromatin and DNA methylation patterns, microbiology, and metagenomics (Ansorge 2009). The main characteristic of these techniques is the 
possibility of performing massive sequencing in a parallel manner, which means that the number of sequences obtained in a single run is much higher than before. But probably the most important fact that is making possible the widespread use of these technologies is their continuously decreasing prices. Generally studies based on NGS have been applied to a single or to a small number of samples although multiplexing is allowing the application of NGS to larger data sets (Harrison and Kidner 2011).

Although the sequencing biochemistry differs among the different methods, the basic steps of most of the next-generation sequencers are similar, involving DNA fragmentation, in vitro adaptor ligation, generation of clonally clustered amplicons, and cyclic sequencing (Shendure and Ji 2008). Massively parallel scale of data production requires enormous computational analysis that includes image analysis, signal processing, background subtraction, base calling, and quality assessment to produce the final sequence reads for each run (Mardis 2008). Magi et al. (2010) reviewed several available software packages for the alignment of sequence reads to a reference, base-calling and/or polymorphism detection, de novo assembly from paired or unpaired reads, structural variant detection, and genome browsing.

\subsection{Applications of NGS in Fruit and Nut Tree Crops}

These NGS techniques are allowing to obtain sequences of entire genomes. Although the number of sequenced genomes is much higher in annual crops, there are some examples of published whole genome sequences in fruit tree crops such as grapevine (Vitis vinifera, Jaillon et al. 2007), papaya (Carica papaya, Ming et al. 2008), apple (Malus domestica, Velasco et al. 2010), date palm (Phoenix dactylifera, Al-Dous et al. 2011), cacao (Theobroma cacao, Argout et al. 2011; Motamayor et al. 2013), peach (Prunus persica, Arus et al. 2012; Verde et al. 2013), Japanese apricot (Prunus mume, Zhang et al. 2012), banana (Musa acuminata, D'Hont et al. 2012), Chinese white pear (Pyrus bretschneideri, Wu et al. 2013), orange (Citrus sinensis, Xu et al. 2013), or wild banana (Musa balbisiana, Davey et al. 2013), and the number of species will surely increase dramatically in the next years.

NGS technologies are permitting to reach every nucleotide on a genome and, thus, variants, common and rare, can be discovered with the appropriate sequencing read coverage and algorithm methods to identify them (Koboldt et al. 2013). In other words, these methodologies allow to detect genomic variation on a wide scale, from single nucleotide polymorphisms (SNPs) to copy number variations in large sequences blocks (Mardis 2008), being a technology with huge potential to allow the study of genetic/genomic diversity, even in non-model species (Garvin et al. 2010). In this sense, one of the most promising recent uses of new generation sequencing technologies is the genotyping-by-sequencing (GBS) approach that provides a high-throughput and cost-effective tool for a genome-wide analysis of genetic diversity (Spindel et al. 2013; Peterson et al. 2014). One of the main 
advantages of this approach is that it does not require a reference genome and allows the development of thousands of SNPs becoming an excellent tool especially for species in which genomic data are limited, such as most fruit tree crops. Deschamps et al. (2012) reviewed the applications of this technology in plant science.

Recently, new generation sequencing approaches have started to be used for diversity analyses in some fruit tree crops. Thus, in date palm (Phoenix dactylifera), nine different varieties were analyzed using NGS technologies, and 3.5 million polymorphic sites were found, including more than 10,000 genic copy number variations (Al-Dous et al. 2011). Kaya et al. (2013) analyzed the transcriptome and genome of five different olive genotypes (Olea europaea) obtaining 126,542,413 reads of cDNA. After assembling, SNPs were filtered and 2,987 high-quality putative SNPs were identified. From three European pear (Pyrus communis) cultivars, using NGS technologies, a subset of 1,096 SNPs were developed into informative markers by combining them with a set of 7,692 apple SNPs (Montanari et al. 2013).

Initiatives like the Genome Database for Rosaceae (GDR) (http://www.rosaceae. org/node/1) which is a curated and integrated web-based relational database that provides centralized access to Rosaceae genomics, genetics and breeding data and analysis tools to facilitate basic, translational, and applied Rosaceae research should be extended to other groups of fruit trees in the next future. In this sense, Russell et al. (2014) have recently developed an open-access, online database, tropiTree (http://bioinf.hutton.ac.uk/tropiTree). Here, simple sequence repeat (EST-SSR) markers for a range of 24 tropical tree species, encountered by bar-coded multiplexed paired-end Illumina NGS, are available to new genetic diversity studies. The sequences developed could also be used for SNP discovery. In fact, sequences already uploaded to databases could serve for developing this promising genome-wide genotyping application; for instance, Sun et al. (2013) downloaded sequences of two Prunus mume cultivars and developed SNPs, indels and SSRs from them.

\section{Use of Geographic Tools and Landscape Genetics in the Study of Genetic Diversity}

\subsection{Geographic Information Systems}

Spatial considerations have to be taken into account in order to understand evolution and, consequently, the development and maintenance of distinct genotypes, population differentiation, and, thus, diversity analysis and conservation (Jarvis et al. 2005). Understanding the spatial patterns of the genetic diversity and population structure of a species can contribute to improve knowledge of temporal and spatial dynamics (Thomas et al. 2012) and optimize diversity conservation and management projects by providing information on how diversity is distributed. 
Guarino et al. (2002) stressed the importance of geographic information systems (GIS) as a tool to handle spatial data in graphic form like the location of the presence points and related different set of nonspatial data, such as species name and morphological, agronomical, or molecular data. GIS can then complement the information obtained from molecular markers to assess the influence of the environment on the presence of specific alleles providing new insights on genotype $\mathrm{x}$ environment interactions. GIS and ecogeographical analysis can then be applied for planning efficient germplasm collection, conservation, characterization, or management. The availability of increasing desktop processing power and the widespread use of GPS receivers allow a detailed study of the spatial components of diversity. There are several software packages available that can handle this type of information, and, besides allowing a spatial visualization of the data, they allow performing multiple statistical analyses. Among the free programs available online, some widely used are QGIS (http://www2.qgis.org/es/site/), DIVA-GIS (http:// www.diva-gis.org/), or Grass (http://grass.osgeo.org/), whereas among those that require a license, the most popular is ArcGIS (https://www.arcgis.com/features). Several recent works analyzing genetic diversity of fruit trees have used a spatial approach for obtaining different diversity indexes both with morphological or molecular data: Annona cherimola (van Zonneveld et al. 2012) or Theobroma cacao (Thomas et al. 2012). The information obtained can be useful to propose different approaches for establishing priorities in conservation based on that diversity as has been shown in Annona cherimola (van Zonneveld et al. 2012) or Prunus africana (Vinceti et al. 2013).

\subsection{Landscape Genetics}

A step forward would be the application of landscape genetics, an approach that combines landscape ecology and population genetics to provide information about microevolutionary processes, such as gene flow and genetic drift and selection (Manel et al. 2003; Manel and Holderegger 2013). The main goal of this new approach is to combine the high resolution obtained from molecular information with spatial data and a variety of statistical methods to evaluate the role that landscape variables play in shaping genetic diversity and population structure (Storfer et al. 2007). A recent and thorough review (Storfer et al. 2010) has described the different topics that have been so far addressed by landscape genetics which include identifying specific barriers to dispersal, quantifying diversity, inferring the effects of landscape change, identifying migrants in relation to landscape conditions, estimating source-sink dynamics, predicting spread of disease or invasive species, and comparing observed genetic patterns between contemporary and historic landscapes. According to Holderegger et al. (2010), three different approaches are currently the most used to assess genetic flow, landscape distance/ resistance, the overlay technique, and the assessment of contemporary gene flow. Storfer et al. (2010) reported that by 2010, landscape studies had been used mainly on vertebrates $(62 \%)$, invertebrates $(18 \%)$, and plants $(14.5 \%)$, followed by 
bacteria (3\%), viruses (3\%), lichens (1\%), and fungi (0.5\%). Recently, landscape genetics has started to be applied to studies of genetic diversity and gene structure in some fruit tree crops such as Castanea sativa (Martin et al. 2012) or Juglans regia (Pollegioni et al. 2014). A new toolbox for ArcGIS has been created by Vandergast et al. (2011) to map patterns of genetic divergence and diversity using a landscape genetic approach.

\section{Conclusions}

Conservation and sustainable use of genetic diversity in fruit tree crops is a global commitment for present and future generations. Locating neutral genetic diversity could be a starting point for selecting material for both conservation and agronomic assessment/breeding programs. As it has been shown in this review, studies of genetic diversity in most fruit trees still use a combination of traditional morphological and molecular markers, although NGS methods will likely replace them since they provide larger amount of information for a continuously decreasing price. In addition, bioinformatic systems to analyze the increasingly larger data sets are also continuously improving both in terms of costs and analyzing power. On the other hand, it is necessary to keep in mind that the huge amount of molecular data that are becoming available will still need phenotypic studies. A paradigm shift that is already taking place is that, in many cases, appropriate phenotyping rather than genotyping is becoming the main limiting factor. Association between nucleotide sequences and functional traits will be needed for agronomic, genetic mapping, functional diversity, breeding, or evolutionary studies. The combination of geographic information systems and vast molecular data sets that will be available in the following years as a result of NGS has a huge potential to both estimate the genetic diversity in a spatial context and to understand the structure and evolution of populations and domestication processes. This would be applicable to both wild and cultivated fruit trees.

Acknowledgments This work was supported by the Spanish Ministerio de Economía y Competitividad-European Regional Development Fund, European Union (AGL2013-43732R), and INIA (RF2012-00010 and RFP2012-00016). NL was supported by an FPI fellowship from the Spanish Ministerio de Economía y Competitividad.

\section{References}

Al-Dous EK, George B, Al-Mahmoud ME, Al-Jaber MY, Wang H, Salameh YM, Al-Azwani EK, Chaluvadi S, Pontaroli AC, DeBarry J, Arondel V, Ohlrogge J, Saie IJ, Suliman-Elmeer KM, Bennetzen JL, Kruegger RR, Malek JA (2011) De novo genome sequencing and comparative genomics of date palm (Phoenix dactylifera). Nat Biotechnol 29:521-527 
Amar MH, Biswas MK, Zhang Z, Guo WW (2011) Exploitation of SSR, SRAP and CAPS-SNP markers for genetic diversity of Citrus germplasm collection. Sci Hortic 128:220-227

Amel SH, Mokhtar T, Salwa Z, Jihene H, Messaoud M, Abdelmajid R, Mohamed M (2004) Intersimple sequence repeat fingerprints to assess genetic diversity in Tunisian fig (Ficus carica L.) germplasm. Genet Resour Crop Evol 51:269-275

Amel SH, Khaled C, Messaoud M, Mohamed M, Mokhtar T (2005) Comparative analysis of genetic diversity in two Tunisian collections of fig cultivars based on random amplified polymorphic DNA and inter simple sequence repeats fingerprints. Genet Resour Crop Evol 52:563-573

Ansorge WJ (2009) Next-generation DNA sequencing techniques. New Biotechnol 25:195-203

Argout X, Salse J, Aury JM, Guiltinan MJ, Droc G, Gouzy J, Allegre M, Chaparro C, Legavre T, Maximova SN, Abrouk M, Murat F, Fouet O, Poulain J, Ruiz M, Roguet Y, Rodier-Goud M, Barbosa-Neto JF, Sabot F, Kudrna D, Ammiraju JSS, Schuster SC, Carlson JE, Sallet E, Schiex T, Dievart A, Kramer M, Gelley L, Shi Z, Bérard A, Viot C, Boccara M, Risterucci AM, Guignon V, Sabau X, Axtell MJ, Ma Z, Zhang Y, Brown S, Bourge M, Golser W, Song X, Clement D, Rivallan R, Tahi M, Akaza JM, Pitollat B, Gramacho K, D'Hont A, Brunel D, Infante D, Kebe I, Costet P, Wing R, McCombie WR, Guiderdoni E, Quetier F, Panaud O, Wincker P, Bocs S, Lanaud C (2011) The genome of Theobroma cacao. Nat Genet 43:101-108

Arias R, Borrone J, Tondo C, Kuhn D, Irish B, Schnell R (2012) Genomics of tropical fruit tree crops. In: Schnell RJ, Priyadarshan PM (eds) Genomics of tree crops. Springer, New York, pp 209-239

Arus P, Verde I, Sosinski B, Zhebentyayeva T, Abbott AG (2012) The peach genome. Tree Genet Genomes 8:531-547

Basheer-Salimia R, Lorenzi S, Batarseh F, Moreno-Sanz P, Emanuelli F, Grando MS (2014) Molecular identification and genetic relationships of Palestinian grapevine cultivars. Mol Biotechnol 56:546-556

Beghe D, Ganino T, Dall'Asta C, Silvanini A, Cirlini M, Fabbri A (2013) Identification and characterization of ancient Italian chestnut using nuclear microsatellite markers. Sci Hortic 164:50-57

Birmeta G, Nybom H, Bekele E (2004) Distinction between wild and cultivated enset (Ensete ventricosum) gene pools in Ethiopia using RAPD markers. Hereditas 140:139-148

Brake M, Migdadi H, Al-Gharaibeh M, Ayoub S, Haddad N, El Oqlah A (2014) Characterization of Jordanian olive cultivars (Olea europaea L.) using RAPD and ISSR molecular markers. Sci Hortic 176:282-289

Breto MP, Ruiz C, Pina JA, Asins MJ (2001) The diversification of Citrus clementina Hort. ex Tan., a vegetatively propagated crop species. Mol Phylogenet Evol 21:285-293

Brown AHD (1978) Isozymes, plant population genetic structure and genetic conservation. Theor Appl Genet 52:145-157

Brown W (1983) Genetic diversity and genetic vulnerability—an appraisal. Econ Bot 37:4-12

Cassman KG (1999) Ecological intensification of cereal production systems: yield potential, soil quality, and precision agriculture. Proc Natl Acad Sci USA 96:5952-5959

Cho KH, Cho KS, Han JH, Kim HR, Shin IS, Kim SH, Chun JA, Hwang HS (2013) Development of sequence characterized amplified region markers for cultivar identification in persimmon. Korean J Hortic Sci 31:798-806

Cornille A, Gladieux P, Giraud T (2013) Crop-to-wild gene flow and spatial genetic structure in the closest wild relatives of the cultivated apple. Evol Appl 6:737-748

Coser SM, da Silva Ferreira MF, Ferreira A, Mitre LK, Carvalho CR, Clarindo WR (2012) Assessment of genetic diversity in Psidium guajava L. using different approaches. Sci Hortic 148:223-229

Crowhurst RN, Gleave AP, MacRae EA, Ampomah-Dwamena C, Atkinson RG, Beuning LL, Bulley SM, Chagne D, Marsh KB, Matich AJ, Montefiori M, Newcomb RD, Schaffer RJ, Usadel B, Allan AC, Boldingh HL, Bowen JH, Davy MW, Eckloff R, Ferguson AR, Fraser LG, Gera E, Hellens RP, Janssen BJ, Klages K, Lo KR, MacDiarmid RM, Nain B, McNeilage MA, 
Rassam M, Richardson AC, Rikkerink EHA, Ross GS, Schröder R, Snowden KC, Souleyre EJF, Templeton MD, Walton EF, Wang D, Wang MY, Wang YY, Wood M, Wu R, Yauk YK, Laing WA (2008) Analysis of expressed sequence tags from Actinidia: applications of a cross species EST database for gene discovery in the areas of flavor, health, color and ripening. BMC Genomics 9:351

D'Hont A, Denoeud F, Aury JM, Baurens FC, Carreel F, Garsmeur O, Noel B, Bocs S, Droc G, Rouard M, Da Silva C, Jabbari K, Cardi C, Poulain J, Souquet M, Labadie K, Jourda C, Lengellé J, Rodier-Goud M, Alberti A, Bernard M, Correa M, Ayyampalayam S, Mckain MR, Leebens-Mack J, Burgess D, Freeling M, Mbéguié-A-Mbéguié D, Chabannes M, Wicker T, Panaud O, Barbosa J, Hribova E, Heslop-Harrison P, Habas R, Rivallan R, Francois P, Poiron C, Kilian A, Burthia D, Jenny C, Bakry F, Brown S, Guignon V, Kema G, Dita M, Waalwijk C, Joseph S, Dievart A, Jaillon O, Leclercq J, Argout X, Lyons E, Almeida A, Jeridi M, Dolezel J, Roux N, Risterucci AG, Weissenbach J, Ruiz M, Glaszmann JC, Quétier F, Yahiaoui N, Wincker P (2012) The banana (Musa acuminata) genome and the evolution of monocotyledonous plants. Nature 488:213-217

Davey MW, Gudimella R, Harikrishna JA, Sin LW, Khalid N, Keulemans J (2013) A draft Musa balbisiana genome sequence for molecular genetics in polyploid, inter- and intra-specific Musa hybrids. BMC Genomics 14:683

De Vicente MC, López C, Fulton T (eds) (2004) Genetic diversity analysis with molecular marker data: learning module. International Plant Genetic Resources Institute (IPGRI), Rome

Deschamps S, Llaca V, May GD (2012) Genotyping-by-sequencing in plants. Biology 1:460-483

Du X, Zhang Q, Luo Z (2009a) Development of retrotransposon primers and their utilization for germplasm identification in Diospyros spp. (Ebenaceae). Tree Genet Genomes 5:235-245

Du XY, Zhang QL, Luo Z (2009b) Comparison of four molecular markers for genetic analysis in Diospyros L. (Ebenaceae). Plant Syst Evol 281:171-181

Ellegren H (2004) Microsatellites: simple sequences with complex evolution. Nat Rev Genet 5: $435-445$

Escribano P, Viruel MA, Hormaza JI (2007) Molecular analysis of genetic diversity and geographic origin within an ex situ germplasm collection of cherimoya by using SSRs. J Am Soc Hortic Sci 132:357-367

Escribano P, Viruel MA, Hormaza JI (2008) Comparison of different methods to construct a core germplasm collection in woody perennial species with SSR markers. A case study in cherimoya (Annona cherimola Mill.), an underutilized subtropical fruit tree species. Ann Appl Biol $153: 25-32$

Excoffier L, Laval G, Schneider S (2005) Arlequin ver. 3.0: an integrated software package for population genetics data analysis. Evol Bioinform Online 1:47-50

FAO (1997) The state of the world's plant genetic resources for food and agriculture. Food and Agriculture Organization of the United Nations, Rome, p 501

Faostat (2014) FAO statistics database on the World Wide Web. http://faostat.fao.org/site/339/ default.aspx. Accessed 12-2014

Ford-Lloyd BV, Schmidt M, Armstrong SJ, Barazani O, Engels J, Hadas R, Hammer K, Kell SP, Kang D, Khoshbakht K, Li Y, Long C, Lu BR, Ma K, Nguyen VT, Qiu L, Ge S, Wei W, Zhang Z, Maxted N (2011) Crop wild relatives-undervalued, underutilized and under threat? Bioscience 61:559-565

Gajera HP, Bambharolia RP, Domadiya RK, Patel SV, Golakiya BA (2014) Molecular characterization and genetic variability studies associated with fruit quality of indigenous mango (Mangifera indica L.) cultivars. Plant Syst Evol 300:1011-1020

Garcia-Ruiz MT, Mendoza-Castillo VM, Valadez-Moctezuma E, Muratalla-Lua A (2013) Initial assessment of natural diversity in Mexican fig landraces. Genet Mol Res 12:3931-3943

Garvin MR, Saitoh K, Gharrett AJ (2010) Application of single nucleotide polymorphisms to non-model species: a technical review. Mol Ecol Resour 10:915-934

Glenn TC (2011) Field guide to next-generation DNA sequencers. Mol Ecol Resour 11:759-769 
Goudet J (2005) Hierfstat, a package for R to compute and test hierarchical F-statistics. Mol Ecol Notes 5:184-186

Graham J, Marshall B, Squire GR (2003) Genetic differentiation over a spatial environmental gradient in wild Rubus ideaus populations. New Phytol 157:667-675

Guarino L, Jarvis A, Hijmans RJ, Maxted N (2002) Geographic information systems (GIS) and the conservation and use of plant genetic resources. In: Engels JEA (ed) Managing plant genetic diversity. CAB International, Wallingford, pp 387-404

Guo L, Palumbo R, Zhang ZS, Wang GL, Tay D, Zhang DL, Shen X, Shu HR (2009) Target Region Amplification Polymorphism (TRAP) for evaluating genetic diversity in Malus Mill. genus. Hortscience 44:1117

Hammer K (2003) A paradigm shift in the discipline of plant genetic resources. Genet Resour Crop Evol 50:3-10

Harrison N, Kidner CA (2011) Next-generation sequencing and systematics: what can a billion base pairs of DNA sequence data do for you? Taxon 60:1552-1566

Holderegger R, Buehler D, Gugerli F, Manel S (2010) Landscape genetics of plants. Trends Plant Sci 15:675-683

Ikegami H, Nogata H, Hirashima K, Awamura M, Nakahara T (2009) Analysis of genetic diversity among European and Asian fig varieties (Ficus carica L.) using ISSR, RAPD, and SSR markers. Genet Resour Crop Evol 56:201-209

Jaillon O, Aury M, Noel B, Policriti A, Clepet C, Casagrande A, Choisne N, Aubourg S, Vitulo N, Jubin C, Vezzi A, Legeai F, Hugueney P, Dasilva C, Horner D, Mica E, Jublot D, Poulain J, Bruyère C, Billault A, Segurens B, Gouyvenoux M, Ugarte E, Cattonaro F, Anthouard V, Vico V, Del Fabbro C, Alaux M, Di Gaspero G, Dumas V, Felice N, Paillard S, Juman I, Moroldo M, Scalabrin S, Canaguier A, Le Clainche I, Malacrida D, Durand E, Pesole G, Laucou V, Chatelet P, Merdinoglu D, Delledonne M, Pezzotti M, Lecharny A, Scarpelli C, Artiguenave F, Pè ME, Valle G, Morgante M, Caboche M, Adam-Blondon AF, Weissenbach J, Quétier F, Wincke P (2007) The grapevine genome sequence suggests ancestral hexaploidization in major angiosperm phyla. Nature 449:463-467

Jarvis A, Yeaman S, Guarino L, Tohme J (2005) The role of geographic analysis in locating, understanding, and using plant genetic diversity. Methods Enzymol 395:279-298

Jeffreys AJ (1979) DNA sequence variants in the G gamma-, A gamma-, delta- and beta-globin genes of man. Cell 18:1-10

Jing ZB, Ruan X, Wang R, Yang Y (2013a) Genetic diversity and relationships between and within persimmon (Diospyros L.) wild species and cultivated varieties by SRAP markers. Plant Syst Evol 299:1485-1492

Jing ZB, Cheng J, Guo CH, Wang XP (2013b) Seed traits, nutrient elements and assessment of genetic diversity for almond (Amygdalus spp.) endangered to China as revealed using SRAP markers. Biochem Syst Ecol 49:51-57

Jombart T (2008) Adegenet: a $\mathrm{R}$ package for the multivariate analysis of genetic markers. Bioinformatics 24:1403-1405

Kalia RK, Rai MK, Kalia S, Singh R, Dhawan AK (2011) Microsatellite markers: an overview of the recent progress in plants. Euphytica 177:309-334

Kaya HB, Cetin O, Kaya H, Sahin M, Sefer F, Kahraman A, Tanyolac B (2013) SNP discovery by illumina-based transcriptome sequencing of the olive and the genetic characterization of Turkish olive genotypes revealed by AFLP, SSR and SNP markers. PLoS One 8(9):e73674

Keenan K, McGinnity P, Cross T, Crozier WW, Prodöhl PA (2013) DiveRsity: an R package for the estimation and exploration of population genetics parameters and their associated errors. Methods Ecol Evol 8:782-788

Kim H, Terakami S, Nishitani C, Kurita K, Kanamori H, Katayose Y, Sawamura Y, Saito T, Yamamoto T (2012) Development of cultivar-specific DNA markers based on retrotransposonbased insertional polymorphism in Japanese pear. Breed Sci 62:53-62

Koboldt DC, Steinberg KM, Larson DE, Wilson RK, Mardis ER (2013) The next-generation sequencing revolution and its impact on genomics. Cell 155:27-38 
Koehmstedt AM, Aradhya MK, Soleri D, Smith JL, Polito VS (2011) Molecular characterization of genetic diversity, structure, and differentiation in the olive (Olea europaea L.) germplasm collection of the United States Department of Agriculture. Genet Resour Crop Evol 58: $519-531$

Larrañaga N, Hormaza JI (2015) DNA barcoding of perennial fruit tree species of agronomic interest in the genus Annona (Annonaceae). Front Plant Sci 6:589

Le Corre V, Kremer A (2003) Genetic variability at neutral markers, quantitative trait loci and trait in a subdivided population under selection. Genetics 164:1205-1219

Leinemann L, Steiner W, Hosius B, Kuchma O, Arenhoevel W, Fussi B, Haase B, Kaetzel R, Rogge M, Finkeldey R (2013) Genetic variation of chloroplast and nuclear markers in natural populations of hazelnut (Corylus avellana L.) in Germany. Plant Syst Evol 299:369-378

Li TF, Liu JR, Xie YN, Wang QY, Meng FJ (2014a) Analysis of genetic diversity in Prunus mira Koehne ex Sargent populations using AFLP markers. Plant Syst Evol 300:475-482

Li D, Liu Y, Li X, Rao J, Yao X, Zhong C (2014b) Genetic diversity in kiwifruit polyploid complexes: insights into cultivar evaluation, conservation, and utilization. Tree Genet Genomes 10:1451-1463

Li M, Zhao Z, Miao X (2014c) Genetic diversity and relationships of apricot cultivars in North China revealed by ISSR and SRAP markers. Sci Hortic 173:20-28

Litt M, Luly JA (1989) A hypervariable microsatellite revealed by in vitro amplification of a dinucleotide repeat within the cardiac muscle actin gene. Am J Hum Genet 44:397-401

Liu K, Muse SV (2005) Power marker: an integrated analysis environment for genetic marker analysis. Bioinformatics 21:2128-2129

Luo C, He X, Chen H, Ou S, Gao M, Brown JS, Tondo CT, Schnell RJ (2011) Genetic diversity of mango cultivars estimated using SCoT and ISSR markers. Biochem Syst Ecol 39:676-684

Madhou M, Normand F, Bahorun T, Hormaza JI (2013) Fingerprinting and analysis of genetic diversity of litchi (Litchi chinensis Sonn.) accessions from different germplasm collections using microsatellite markers. Tree Genet Genomes 9:387-396

Magi A, Benelli M, Gozzini A, Girolami F, Torricelli F, Brandi ML (2010) Bioinformatics for next generation sequencing data. Genes 1:294-307

Malik SK, Uchoi A, Kumar S, Choudhary R, Pal D, Kole PR, Chaudhury R, Bhat KV (2013) Molecular characterization of Citrus macroptera Montr. (satkara): an endangered wild species from northeast India. Plant Biosyst 147:857-863

Manel S, Holderegger R (2013) Ten years of landscape genetics. Trends Ecol Evol 28:614-621

Manel S, Schwartz MK, Luikart G, Taberlet P (2003) Landscape genetics: combining landscape ecology and population genetics. Trends Ecol Evol 18:189-197

Mansour E, Ben Khaled A, Triki T, Abid M, Bachar K, Ferchichi A (2015) Evaluation of genetic diversity among South Tunisian pomegranate (Punica granatum L.) accessions using fruit traits and RAPD markers. J Agric Sci Biotechnol 17:109-119

Mardis ER (2008) Next-generation DNA sequencing methods. Annu Rev Genomics Hum Genet 9:387-402

Martin C, Herrero M, Hormaza JI (2011) Molecular characterization of apricot germplasm from an old stone collection. PLoS One 6(8):e23979

Martin M, Mattioni C, Molina JR, Alvarez JB, Cherubini M, Herrera MA, Villani F, Martin LM (2012) Landscape genetic structure of chestnut (Castanea sativa Mill.) in Spain. Tree Genet Genomes 8:127-136

Maxam AM, Gilbert W (1977) A new method for sequencing DNA. Proc Natl Acad Sci USA 74: $560-564$

Mba C, Tohme J (2005) Use of AFLP markers in surveys of plant diversity. Methods Enzymol 395:177-201

Mba C, Guimaraes E, Ghosh K (2012) Re-orienting crop improvement for the changing climatic conditions of the 21st century. Agric Food Secur 1:1-17

McClure KA, Sawler J, Gardner KM, Money D, Myles S (2014) Genomics: a potential panacea for the perennial problem. Am J Bot 101:1780-1790 
Ming R, Hou S, Feng Y, Yu Q, Dionne-Laporte A, Saw JH, Senin P, Wang W, Ly BV, Lewis KL, Salzberg SL, Feng L, Jones MR, Skelton RL, Murray JE, Chen C, Qian W, Shen J, Du P, Eustice M, Tong E, Tang H, Lyons E, Paull RE, Michael TP, Wall K, Rice DW, Albert H, Wang ML, Zhu YJ, Schatz M, Nagarajan N, Acob RA, Guan P, Blas A, Wai CM, Ackerman CM, Ren Y, Liu C, Wang J, Wang J, Na JK, Shakirov EV, Haas B, Thimmapuram J, Nelson D, Wang X, Bowers JE, Gschwend AR, Delcher AL, Singh R, Suzuki JY, Tripathi S, Neupane K, Wei H, Irikura B, Paidi M, Jiang N, Zhang W, Presting G, Windsor A, Navajas-Pérez R, Torres MJ, Feltus FA, Porter B, Li Y, Burroughs AM, Luo MC, Liu L, Christopher DA, Mount SM, Moore PH, Sugimura T, Jiang J, Schuler MA, Friedman V, Mitchell-Olds T, Shippen DE, dePamphilis CW, Palmer JD, Freeling M, Paterson AH, Gonsalves D, Wang L, Alam M (2008) The draft genome of the transgenic tropical fruit tree papaya (Carica papaya Linnaeus). Nature 452:991-996

Mondini L, Noorani A, Pagnotta MA (2009) Assessing plant genetic diversity by molecular tools. Diversity 1:19-35

Montanari S, Saeed M, Knaebel M, Kim Y, Troggio M, Malnoy M, Velasco R, Fontana P, Won K, Durel CE, Perchepied L, Schaffer R, Wiedow C, Bus V, Brewer L, Gardiner SE, Crowhurst RN, Chagné D (2013) Identification of Pyrus single nucleotide polymorphisms (SNPs) and evaluation for genetic mapping in European pear and interspecific Pyrus hybrids. PLoS One 8(10):e77022

Motamayor JC, Mockaitis K, Schmutz J, Haiminen N, Livingstone D III, Cornejo O, Findley SD, Zheng P, Utro F, Royaert S, Saski C, Jenkins J, Podicheti R, Zhao M, Scheffler BE, Stack JC, Feltus FA, Mustiga GM, Amores F, Phillips W, Marelli JP, May GD, Shapiro H, Ma J, Bustamante CD, Schnell RJ, Main D, Gilbert D, Parida L, Kuhn DN (2013) The genome sequence of the most widely cultivated cacao type and its use to identify candidate genes regulating pod color. Genome Biol 14:r53

Mullis K, Faloona F, Scharf S, Saiki R, Horn G, Erlich H (1986) Specific enzymatic amplification of DNA in vitro: the polymerase chain reaction. Cold Spring Harb Symp Quant Biol 51: 263-273

Munthali CRY, Chirwa PW, Changadeya WJ, Akinnifesi FK (2013) Genetic differentiation and diversity of Adansonia digitata L. (baobab) in Malawi using microsatellite markers. Agrofor Syst 87:117-130

Nair AS, Teo CH, Schwarzacher T, Harrison PH (2005) Genome classification of banana cultivars from South India using IRAP markers. Euphytica 144:285-290

Passos MAN, de Oliveira CV, Emediato FL, de Camargo TC, Souza MT, Matsumoto T, Renno Azevedo VC, Ferreira CF, Amorim EP, de Alencar Figueiredo LF, Martins NF, de Jesus Barbosa Cavalcante M, Baurens FC, da Silva OB, GJ P Jr, Pignolet L, Abadie C, Ciampi AY, Piffanelli P, Miller RN (2012) Development of expressed sequence tag and expressed sequence tag-simple sequence repeat marker resources for Musa acuminata. AoB Plants 2012:pls030. doi:10.1093/aobpla/pls030

Peakall R, Smouse P (2012) GenAlEx 6.5: genetic analysis in Excel. Population genetic software for teaching and research-an update. Bioinformatics 28:2537-2539

Peterson GW, Dong Y, Horbach C, Fu Y (2014) Genotyping-by-sequencing for plant genetic diversity analysis: a lab guide for SNP genotyping. Diversity 6:665-680

Pollegioni P, Woeste KE, Chiocchini F, Olimpieri I, Tortolano V, Clark J, Hemery GE, Mapelli S, Malvolti ME (2014) Landscape genetics of Persian walnut (Juglans regia L.) across its Asian range. Tree Genet Genomes 10:1027-1043

Porth I, El-Kassaby YA (2014) Assessment of the genetic diversity in forest tree populations using molecular markers. Diversity 6:283-295

Pritchard JK, Stephens M, Donnelly P (2000) Inference of population structure using multilocus genotype data. Genetics 155:945-959

Raji R, Jannatizadeh A, Fattahi R, Esfahlani MA (2014) Investigation of variability of apricot (Prunus armeniaca L.) using morphological traits and microsatellite markers. Sci Hortic 176: 225-231 
Raymond M, Rousset F (1995) GENEPOP (version 1.2): population genetics software for exact tests and ecumenicism. J Hered 86:248-249

Rohlf FJ (2008) NTSYSpc: numerical taxonomy system, ver. 2.20. Exeter Publishing, Setauket, NY

Russell JR, Hedley PE, Cardle L, Dancey S, Morris J, Booth A, Odee D, Mwaura L, Omondi W, Angaine P, Machua J, Muchugi A, Milne I, Kindt R, Jamnadass R, Dawson IK (2014) TropiTree: an NGS-based EST-SSR resource for 24 tropical tree species. PLoS One 9:e102502

Sabir JSM, Abo-Aba S, Bafeel S, Zari TA, Edris S, Shokry AM, Atef A, Gadalla NO, Ramadan AM, Al-Kordy MA, El-Domyati FM, Jansen RK, Bahieldin A (2014) Characterization of ten date palm (Phoenix dactylifera $\mathrm{L}$.) cultivars from Saudi Arabia using AFLP and ISSR markers. C R Biol 337:6-18

Samal KC, Jena RC, Swain SS, Das BK, Chand PK (2012) Evaluation of genetic diversity among commercial cultivars, hybrids and local mango (Mangifera indica L.) genotypes of India using cumulative RAPD and ISSR markers. Euphytica 185:195-213

Sanger F, Nicklen S, Coulson AR (1977) DNA sequencing with chain-terminating inhibitors. Proc Natl Acad Sci USA 74:5463-5467

Sehic J, Garkava-Gustavsson L, Fernandez-Fernandez F, Nybom H (2012) Genetic diversity in a collection of European pear (Pyrus communis) cultivars determined with SSR markers chosen by ECPGR. Sci Hortic 145:39-45

Shanjani PS, Mardi M, Pazouki L, Hagidimitriou M, Avanzato D, Pirseyedi SM, Ghaffari MR, Nekoui SMK (2009) Analysis of the molecular variation between and within cultivated and wild Pistacia species using AFLPs. Tree Genet Genomes 5:447-458

Shen Y, Ding X, Wang F, Cai B, Gao Z, Zhang Z (2011) Analysis of genetic diversity in Japanese apricot (Prunus mume Sieb. et Zucc.) based on REMAP and IRAP molecular markers. Sci Hortic 132:50-58

Shendure J, Ji H (2008) Next-generation DNA sequencing. Nat Biotechnol 26:1135-1145

Spindel J, Wright M, Chen C, Cobb J, Gage J, Harrington S, Lorieux M, Ahmadi N, McCouch S (2013) Bridging the genotyping gap: using genotyping by sequencing (GBS) to add highdensity SNP markers and new value to traditional bi-parental mapping and breeding populations. Theor Appl Genet 126:2699-2716

Storfer A, Murphy MA, Evans JS, Goldberg CS, Robinson S, Spear SF, Dezzani R, Delmelle E, Vierling L, Waits LP (2007) Putting the 'landscape' in landscape genetics. Heredity 98: $128-142$

Storfer A, Murphy MA, Spear SF, Holderegger R, Waits LP (2010) Landscape genetics: where are we now? Mol Ecol 19:3496-3514

Sun LD, Zhang QX, Xu ZD, Yang WR, Guo Y, Lu JX, Pan HT, Cheng TR, Cai M (2013) Genomewide DNA polymorphisms in two cultivars of mei (Prunus mume Sieb. et Zucc.). BMC Genet 14:98

Syed NH, Sureshsundar S, Wilkinson MJ, Bhau BS, Cavalcanti JJV, Flavell AJ (2005) Ty1-copia retrotransposon-based SSAP marker development in cashew (Anacardium occidentale L.). Theor Appl Genet 110:1195-1202

Takrouni MM, Ali IB, Messaoued C, Boussaid M (2012) Genetic variability of Tunisian wild strawberry tree (Arbutus unedo L.) populations interfered from isozyme markers. Sci Hortic 146:92-98

Tamura K, Stecher G, Peterson D, Filipski A, Kumar S (2013) MEGA6: molecular evolutionary genetics analysis version 6.0. Mol Biol Evol 30:2725-2729

Thomas E, van Zonneveld M, Loo J, Hodgkin T, Galluzzi G, van Etten J (2012) Present spatial diversity patterns of Theobroma cacao L. in the neotropics reflect genetic differentiation in Pleistocene refugia followed by human-influenced dispersal. PLoS One 7:e47676

van Droogenbroeck B, Kyndt T, Maertens I, Romeijn-Peeters E, Scheldeman X, Romero-Motochi JP, Van Damme P, Goetghebeur P, Gheysen G (2004) Phylogenetic analysis of the highland papayas (Vasconcellea) and allied genera (Caricaceae) using PCR-RFLP. Theor Appl Genet 108:1473-1486 
van Droogenbroeck B, Kyndt T, Romeijn-Peeters E, van Thuyne W, Goetghebeur P, RomeroMotochi JP, Gheysen G (2006) Evidence of natural hybridization and introgression between Vasconcellea species (Caricaceae) from southern Ecuador revealed by chloroplast, mitochondrial and nuclear DNA markers. Ann Bot 97:793-805

van Hintum T, Brown AHD, Spillane C, Hodgkin T (2000) Core collections of plant genetic resources. IPGRI Technical Bulletin No. 3. International Plant Genetic Resources Institute, Rome

van Zonneveld M, Scheldeman X, Escribano P, Viruel MA, Van Damme P, Garcia W, Tapia C, Romero J, Siguenas M, Hormaza JI (2012) Mapping genetic diversity of cherimoya (Annona cherimola Mill.): application of spatial analysis for conservation and use of plant genetic resources. PLoS One 7:e29845

Vandergast AG, Perry WM, Lugo RV, Hathaway SA (2011) Genetic landscapes GIS Toolbox: tools to map patterns of genetic divergence and diversity. Mol Ecol Resour 11:158-161

Velasco R, Zharkikh A, Affourtit J, Dhingra A, Cestaro A, Kalyanaraman A, Fontana P, Bhatnagar SK, Troggio M, Pruss D, Salvi S, Pindo M, Baldi P, Castelletti S, Cavaiuolo M, Coppola G, Costa F, Cova V, Dal Ri A, Goremykin V, Komjanc M, Longhi S, Magnago P, Malacarne G, Malnoy M, Micheletti D, Moretto M, Perazzolli M, Si-Ammour A, Vezzulli S (2010) The genome of the domesticated apple (Malus x domestica Borkh.). Nat Genet 42:833-839

Verde I, Abbott AG, Scalabrin S, Jung S, Shu S, Marroni F, Zhebentyayeva T, Dettori MT, Grimwood J, Cattonaro F, Zuccolo A, Rossini L, Jenkins J, Vendramin E, Meisel LA, Decroocq V, Sosinski B, Prochnik S, Mitros T, Policriti A, Cipriani G, Dondini L, Ficklin S, Goodstein DM, Xuan P, Del Fabbro C, Aramini V, Copetti D, Gonzalez S, Horner DS, Falchi R, Lucas S, Mica E, Maldonado J, Lazzari B, Bielenberg D, Pirona R, Miculan M, Barakat A, Testolin R, Stella A, Tartarini S, Tonutti P, Arús P, Orellana A, Wells C, Main D, Vizzotto G, Silva H, Salamini F, Schmutz J, Morgante M, Rokhsar DS (2013) The high-quality draft genome of peach (Prunus persica) identifies unique patterns of genetic diversity, domestication and genome evolution. Nat Genet 45:487-494

Vinceti B, Loo J, Gaisberger H, van Zonneveld M, Schueler S, Konrad H, Kadu CAC, Geburek T (2013) Conservation priorities for Prunus africana defined with the aid of spatial analysis of genetic data and climatic variables. PLoS One 8:e59987

Vos P, Hogers R, Bleeker M, Reijans M, van de Lee T, Hornes M, Fritjters A, Pot J, Peleman J, Kuiper M, Zabeau M (1995) AFLP: a new technique for DNA fingerprinting. Nucleic Acids Res 23:4407-4414

Wagner I, Maurer WD, Lemmen P, Schmitt HP, Wagner M, Binder M, Patzak P (2014) Hybridization and genetic diversity in wild apple (Malus sylvestris (L.) Mill) from various regions in Germany and from Luxembourg. Silvae Genet 63:81-94

Warschefsky E, Penmetsa RY, Cook DR, von Wettberg EJB (2014) Back to the wilds: tapping evolutionary adaptations for resilient crops through systematic hybridization with crop wild relatives. Am J Bot 101:1791-1800

Wijeratnam RSW (2000) Identification of problems in processing of underutilized fruits of the tropics and their solutions. Acta Hortic 518:237-240

Williams JGK, Kuberik AR, Livak KJ, Rafalski JA, Tingey SV (1990) DNA polymorphisms amplified by arbitrary primers are useful as genetic markers. Nucleic Acids Res 18:6531-6535

Wu J, Wang Z, Shi Z, Zhang S, Ming R, Zhu S, Khan MA, Tao S, Korban SS, Wang H, Chen NJ, Nishio T, Xu X, Cong L, Qi K, Huang X, Wang Y, Zhao X, Wu J, Deng C, Gou C, Zhou W, Yin H, Qin G, Sha Y, Tao Y, Chen H, Yang Y, Song Y, Zhan D, Wang J, Li L, Dai M, Gu C, Wang Y, Shi D, Wang X, Zhang H, Zeng L, Zheng D, Wang C, Chen M, Wang G, Xie L, Sovero V, Sha S, Huang W, Zhang S, Zhang M, Sun J, Xu L, Li Y, Liu X, Li Q, Shen J, Wang J, Paull RE, Bennetzen JL, Wang J, Zhang S (2013) The genome of the pear (Pyrus bretschneideri Rehd.). Genome Res 23:396-408

Wünsch A, Hormaza JI (2002) Cultivar identification and genetic fingerprinting of temperate fruit tree species using DNA markers. Euphytica 125:59-67 
Xu Q, Chen LL, Ruan X, Chen D, Zhu A, Chen C, Bertrand D, Jiao WB, Hao BH, Lyon MP, Chen J, Gao S, Xing F, Lan H, Chang JW, Ge X, Lei Y, Hu Q, Miao Y, Wang L, Xiao S, Biswas MK, Zeng W, Guo F, Cao H, Yang X, Xu XW, Cheng YJ, Xu J, Liu JH, Luo OJ, Tang Z, Guo WW, Kuang H, Zhang HY, Roose ML, Nagarajan N, Deng XX, Ruan Y (2013) The draft genome of sweet orange (Citrus sinensis). Nat Genet 45:59-66

Yeh FC, Yang RC, Boyle TBJ, Ye ZH, Mao JX (1997) POPGENE, the user-friendly shareware for population genetic analysis. Molecular Biology and Biotechnology Centre, University of Alberta, Edmonton

Yilmaz KU, Paydas-Kargi S, Dogan Y, Kafkas S (2012) Genetic diversity analysis based on ISSR, RAPD and SSR among Turkish apricot germplasms in Iran Caucasian eco-geographical group. Sci Hortic 138:138-143

Zhang Q, Chen W, Sun L, Zhao F, Huang B, Yang W, Tao Y, Wang J, Yuan Z, Fan G, Xing Z, Han C, Pan H, Zhong X, Shi W, Liang X, Du D, Sun F, Xu Z, Hao R, Lv T, Lv Y, Zheng Z, Sun M, Luo L, Cai M, Gao Y, Wang J, Yin Y, Xu X, Cheng T, Wang J (2012) The genome of Prunus mume. Nat Commun 3:1318 